\title{
Rape in the Nordic Countries
}

\section{Continuity and Change}

Heinskou, Marie Bruvik; Skilbrei, May-Len; Stefansen, Kari

DOI:

$10.4324 / 9780429467608$

Publication date:

2019

Document version

Publisher's PDF, also known as Version of record

Document license:

CC BY-NC-ND

Citation for published version (APA):

Heinskou, M. B., Skilbrei, M-L., \& Stefansen, K. (2019). Rape in the Nordic Countries: Continuity and Change. (1 ed.) Routledge. Research in gender and Society No. 84 https://doi.org/10.4324/9780429467608 


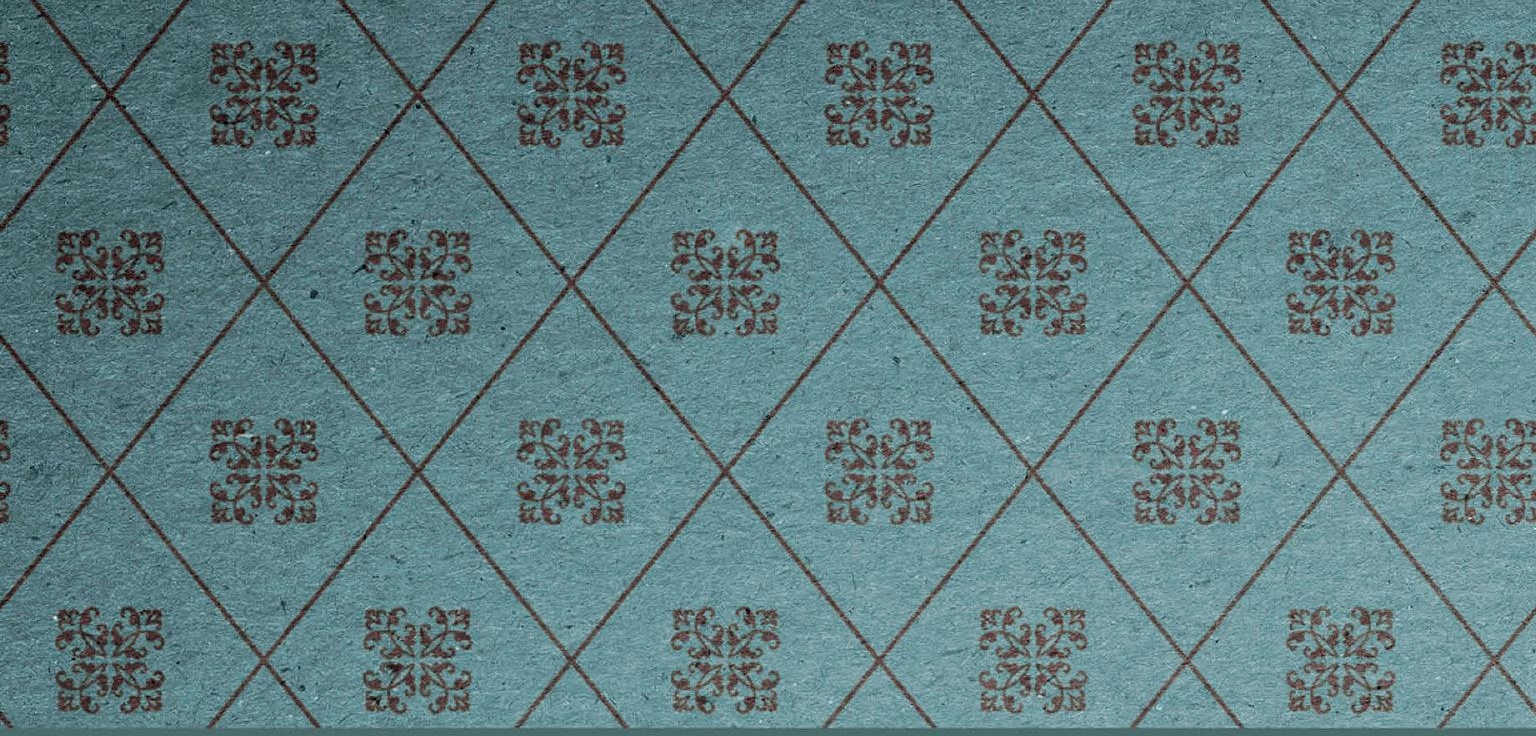

Routledge Research in Gender and Society

\section{RAPE IN THE NORDIC COUNTRIES}

\section{CONTINUITY AND CHANGE}

Edited by

Marie Bruvik Heinskou, May-Len Skilbrei and Kari Stefansen

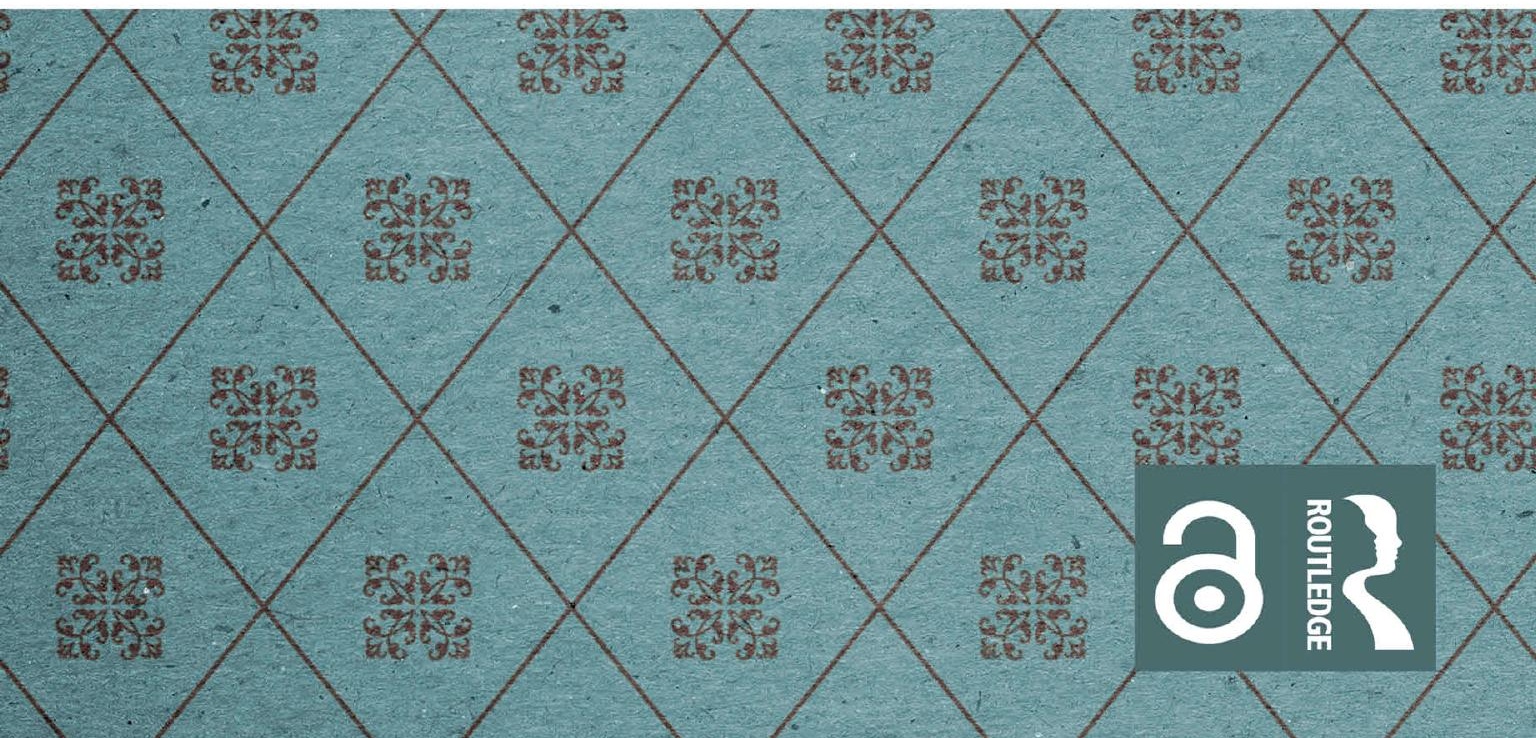


"This edited collection constitutes a landmark in helping a wider audience appreciate the challenges in assuming a 'Nordic exceptionalism' when it comes to rape and sexual violence. The chapters in this book demonstrate the continuities and differences within Nordic countries and places elsewhere in the world in making sense of what counts as rape and sexual violence, how to count these experiences, and how to make sense of the perpetrators both 'real' and 'digital'. It is a collection which is remarkable in its nuance and its wider contribution to the literature. No matter how much you might think you know about rape and sexual violence, you will definitely benefit from reading the excellent and thought provoking contributions found here."

- Sandra Walklate, Eleanor Rathbone Chair of Sociology, University of Liverpool, UK, and Conjoint Chair of Criminology, Monash University, Australia

"This is a truly exceptional volume on how to study, make sense of, and address rape and sexual harm. Focusing on the Nordic region, it provides rich new research on perpetration, victimization, criminal justice, and prevention. The chapters also develop theoretical frameworks that can and should be engaged well beyond this context. It is necessary reading for all those interested in the Nordic region, and to all those interested sexual assault, gender, and public policy."

- Shamus Khan, Professor and Chair, Department of Sociology, Columbia University, USA 
$\because$ Taylor \& Francis

Taylor \& Francis Group

http://taylorandfrancis.com 


\section{Rape in the Nordic Countries}

While the Nordic countries are listed at the top in most international rankings of gender equality and citizens' feelings of security, studies on the prevalence of sexual victimisation present a different picture, suggesting that the very countries that have invested much in establishing gender equality actually see a high prevalence of sexual violence. This book sheds light on the phenomenon and construction of rape and other forms of sexual violence within the Nordic region, exploring the ways in which rape and sexual violence are dealt with through criminal law and considering governmental policies aimed at combatting it, with a special focus on legal regulations and developments. Thematically organised, it offers new research on perpetrators, victimhood, criminal justice and prevention. Multi-disciplinary in approach, it brings together the latest work from a range of scholars to offer insights into the situation in the five Nordic countries, asking how and why rape and other forms of sexual violence occur, whilst also addressing the timely issues of online sexual cultures, BDSM and the grey areas of sexual offences. As such, it will appeal to scholars of sociology, criminology and law with interests in gender and sexual violence.

Marie Bruvik Heinskou works as Commissioning Editor at Hans Reitzels Publishing House and as external lecturer at the Department of Political Science, University of Copenhagen. She is former Associate Professor of Sociology at Aalborg University, Denmark, and has published on sexual violence and violence in leading international journals.

May-Len Skilbrei is Professor at the Department of Criminology and Sociology of Law at the University of Oslo. She also holds a position at Norwegian Social Research (NOVA) at Oslo Metropolitan University. Her research interests are gender, sexuality, power and law and she has published books, articles and chapters internationally on how Nordic governments and civil society actors approach prostitution, human trafficking, child sexual abuse and sexual violence.

Kari Stefansen works as a Research Professor at Norwegian Social Research, Oslo Metropolitan University, Norway. In 2017-2018 she was affiliated with the Norwegian Centre for Violence and Traumatic Stress Studies (NKVTS). Stefansen is the co-editor of Collaborating against Child Abuse: Exploring the Nordic Barnahus Model. Her current research focuses on youth and sexual violence. 


\section{Routledge Research in Gender and Society}

79 Contemporary Muslim Girlhoods in India

A Study of Social Justice, Identity and Agency in Assam

Saba Hussain

80 White Masculinity in Contemporary Australia

The Good Ol' Aussie Bloke

Andrea Waling

81 Motherhood in Contemporary International Perspective

Continuity and Change

Edited by Fabienne Portier-Le Cocq

82 Gender Violence in Ecofeminist Perspective

Intersections of Animal Oppression, Patriarchy and Domination of the Earth Gwen Hunnicutt

83 Reframing Drag

Beyond Subversion and the Status Quo

Kayte Stokoe

84 Rape in the Nordic Countries

Continuity and Change

Edited by Marie Bruvik Heinskou, May-Len Skilbrei and Kari Stefansen

85 Refracting through Technologies

Bodies, Medical Technologies and Norms

Ericka Johnson

For more information about this series, please visit: www.routledge.com/ sociology/series/SE0271 


\section{Rape in the Nordic Countries Continuity and Change}

Edited by Marie Bruvik Heinskou, May-Len Skilbrei and Kari Stefansen 
First published 2020

by Routledge

2 Park Square, Milton Park, Abingdon, Oxon OX14 4RN

and by Routledge

52 Vanderbilt Avenue, New York, NY 10017

Routledge is an imprint of the Taylor \& Francis Group, an informa business

(C) 2020 selection and editorial matter, Marie Bruvik Heinskou, May-Len

Skilbrei and Kari Stefansen; individual chapters, the contributors

The right of Marie Bruvik Heinskou, May-Len Skilbrei and Kari

Stefansen to be identified as the authors of the editorial material, and of the authors for their individual chapters, has been asserted in accordance with sections 77 and 78 of the Copyright, Designs and Patents Act 1988

The Open Access version of this book, available at www.taylorfrancis. com, has been made available under a Creative Commons AttributionNon Commercial-No Derivatives 4.0 license.

Trademark notice: Product or corporate names may be trademarks or registered trademarks, and are used only for identification and explanation without intent to infringe.

British Library Cataloguing-in-Publication Data

A catalogue record for this book is available from the British Library

Library of Congress Cataloging-in-Publication Data

Names: Heinskou, Marie Bruvik, editor. | Skilbrei, May-Len, editor. |

Stefansen, Kari, 1971- editor.

Title: Rape in the Nordic countries : continuity and change / edited by Marie Bruvik Heinskou, May-Len Skilbrei and Kari Stefansen.

Description: Abingdon, Oxon : New York, NY Routledge, 2020. |

Series: Routledge research in gender and society | Includes bibliographical references and index.

Identifiers: LCCN 2019027110 (print) | LCCN 2019027111 (ebook) |

ISBN 9781138606517 (hbk) | ISBN 9780429467608 (ebk)

Subjects: LCSH: Rape-Scandinavia. | Sex crimes-Scandinavia.

Classification: LCC HV6569.S44 R37 2020 (print) | LCC HV6569.S44

(ebook) | DDC 364.15/320948-dc23

LC record available at https://lccn.loc.gov/2019027110

LC ebook record available at https://lccn.loc.gov/2019027111

ISBN: 978-1-138-60651-7 (hbk)

ISBN: 978-0-429-46760-8 (ebk)

Typeset in Times New Roman

by Integra Software Services Pvt. Ltd. 


\section{Contents}

List of illustrations $\quad$ ix

List of contributors $\quad \mathrm{X}$

Preface $\quad$ XV

1 A Nordic research agenda on rape and sexual violence 1 MAY-LEN SKILBREI, KARI STEFANSEN AND MARIE BRUVIK HEINSKOU

2 Theorising sexual violence in intimate relations in Scandinavia: A literature review

MARGUNN BJøRNHOLT

3 Cultivating ethical negotiations or fetishising consent in BDSM? MONIKA GRøNLI ROSTEN

4 Understanding unwanted sexual touching: A situational approach KARI STEFANSEN

5 Making the case for 'good enough' rape-prevalence estimates: Insights from a school-based survey experiment among Norwegian youths

KARI STEFANSEN, METTE LøVGREN AND LARS ROAR FRøYLAND

6 From the protection of marriage to the defence of equality: The Finnish debate over the sexual autonomy of wives

RIIKKA KOTANEN

7 Towards voluntariness in Swedish rape law: Hyper-medialised group rape cases and the shift in the legal discourse

GABRIELLA NILSSON

8 Rape law and coercive circumstances 


\section{viii Contents}

9 Empowered or protected? The 'problem' of complainants' rights in Danish and Norwegian preparatory works on criminal procedure HILDUR FJÓLA ANTONSDÓTTIR

10 Othering the rapist: Rurality, sexual violence and the Bjästa case LUCAS GOTTZÉN AND ANNA G. FRANZÉN

11 Sexual transgressing: Situational and narrative perspectives

LAURA MARIE SCHIERFF AND MARIE BRUVIK HEINSKOU

12 Rape in the age of the Internet

ELISABETH FRANSSON, TROND MARTINSEN AND ELISABETH STAKSRUD

13 Digital sexual violence: Image-based sexual abuse among Danish youth

SIDSEL KIRSTINE HARDER, KATHRINE ELMOSE JøRGENSEN, JONATHAN PRIESHOLM GÅRDSHUS AND JAKOB DEMANT

14 Breaking the silence: Social media disclosures of sexual violence in Iceland

RANNVEIG SIGURVINSDÓTTIR, BRYNDÍS BJÖRK ÁSGEIRSDÓTTIR AND SARA ARNALDS

Index 


\section{Illustrations}

\section{Figures}

13.1 Model showing the relation between independent, dependent, background and mediating variables

13.2 The predicted probabilities for offending dependent on self-control, based on regression estimates of the full model

14.1 Number of self-disclosure posts of sexual violence over time

\section{Tables}

5.1 All items. Prevalence of positive responses. By gender. Frequency and percent

5.2 Three measures of rape. Boys and girls. Between-group mean comparison. $t$-Test

5.3 Rape measures and socio-economic characteristics. Girls. Between-group mean comparison. $t$-Test

13.1 Summary statistics of all variables included in the models

13.2 Pairwise correlation coefficients of all the variables included in the study

13.3 Regression table presenting estimates in odds ratios for the two models. Standard errors are clustered by institution 


\section{Contributors}

Hildur Fjóla Antonsdóttir is a doctoral candidate at the Department of Sociology of Law at Lund University in Sweden. Her research interests include sexual violence and justice, both social and legal justice. The focus of her $\mathrm{PhD}$ thesis centres on the meaning of justice for people who have been subjected to sexual violence and how their experiences of and opinions about justice relate to traditional and non-traditional justice mechanisms and processes. Previously, she worked in the field of international development and gender-based violence.

Sara Arnalds is a BSc psychology graduate student from Reykjavik University. Her research interests include trauma and her BSc thesis emphasised on survivors of violence.

Bryndís Björk Ásgeirsdóttir is an Associate Professor at the Department of Psychology, Reykjavik University. Her field of research includes the impact of sexual abuse and family conflict/violence in the lives of children and adolescents. She has published numerous articles in scientific journals on protective factors in the lives of adolescents when facing sexual abuse and on pathways from sexual abuse and family conflict/violence to emotional problems and risk behaviours, including suicidal and self-injurious behaviour, substance use and delinquency.

Margunn Bjørnholt is a Research Professor at the Norwegian Centre for Violence and Traumatic Stress Studies (NKVTS). Her background is in Sociology and Gender Studies, and her research covers violence, work, family and gender equality, and migration. She publishes widely and among her recent publications are an article on revictimisation of intimate partner violence published in the Nordic Journal of Criminology and 'Measuring violence, mainstreaming gender; does adding harm make a difference?', coauthored with O. K. Hjemdal, published in the Journal of Gender-Based Violence. She is also co-editor of two edited volumes: a Norwegian language book on violence in intimate relations, co-edited with Kristin Skjørten, Elisiv Bakketeig and Svein Mossige, and Men, Masculinities and Intimate Partner Violence, co-edited with Lucas Gottzén and Floretta Boonzaier, to be published by Routledge. 
Jakob Demant is Associate Professor from Department of Sociology, University of Copenhagen. He researches online/digital deviance from the perspective of criminology, microsociology and digital sociology. In recent years, he has developed considerable expertise in the field of digital computational methods, including techniques such as web scraping, machine learning, and topic modelling on public forums, social media and the darknet. Further, he has initiated and analysed data from digital ethnographic within the hard-to-reach populations. Author of 50+ publications on the subject of crime, sexuality, alcohol, drugs, media and cryptomarkets and an experienced communicator.

Elisabeth Fransson is Associate Professor at the University College of Norwegian Correctional Service in Norway. Her research interests include children and youths exposed to crime, correctional care as knowledge and field of practice, prison architecture, materiality and the body. Fransson manages the PriArcH network; she has published several articles within the field of penology and is one of the editors of the book Prison, Architecture and Humans.

Anna G. Franzén is an Assistant Professor in child and youth studies, Stockholm University, Sweden. Drawing mainly on a discursive framework, her research at large centres on young men in forced institutions and issues of violence, crime and identity. She has conducted several video-ethnographic studies of institutions such as detention homes and prisons, as well as in schools analysing issues such as subjectivity, power and resistance - in interaction.

Lars Roar Frøyland is a PhD candidate in The Domestic Violence Research Program at Norwegian Social Research (NOVA), OsloMet - Oslo Metropolitan University (Section for Youth Research). His main research interests are adolescent deviant and delinquent behaviour, as well as aspects related to well-being and prosperity during adolescence. Frøyland has extensive experience with collection and analysis of quantitative data. He is currently working on a dissertation on adolescent perpetrators of violence and aggression for submission at the Department of Psychology at the University of Oslo. He holds an MA in sociology from the University of Oslo (2009).

Lucas Gottzén is a Professor at the Department of Child and Youth Studies, Stockholm University, Sweden. His research takes feminist and critical perspectives on boys, men and masculinities, particularly focusing on sexuality and gender-based violence. He has carried out larger studies on family life; fatherhood; violence prevention programs; and young and adult men's subjective experiences of their intimate partner violence.

Jonathan Priesholm Gårdshus is a Research Assistant at Department of Sociology, University of Copenhagen. He holds a strong methodological profile in semiautomatic text analysis (using the co-word method) of Facebook debates and works experimentally with new ways of investigating the intersection of online and offline social life and crimes. Throughout his studies 
and employment, he has acquired extensive theoretical understanding and practical experience with quantitative social research.

Sidsel Kirstine Harder, sociologist, is a PhD student at the Department of Sociology, University of Copenhagen. Her thesis analyses the social practice of producing, using and sharing digital, sexual images with and without consent and situates these phenomena in the context of young adult's everyday lives. She works in the cross section of criminology, gender studies and sociology and mixes methods ranging from surveys and interviews to analysis of visuals and documents. She has previously published on nightlife sexuality in drug research and designed youth interventions as a consultant.

Marie Bruvik Heinskou is a sociologist, Commissioning Editor at Hans Reitzels Publishing House and External lecturer at Department of Political Science, University of Copenhagen. She has researched and published in the field of rape, prostitution and violence

Helena Jokila is a legal scholar with a $\mathrm{PhD}$ in law from University of Helsinki, Finland. She has worked at the University of Helsinki and University of Turku. Her PhD dissertation is on evidence in cases of sex crimes, and she has published several articles on sexual crimes. In recent years, she has participated in the research projects "Structures, Actors and Law" (2015-2016), and "Legal Constructions of Reality" (2007-2010), both funded by the Academy of Finland.

Kathrine Elmose Jørgensen is a $\mathrm{PhD}$ fellow at Faculty of Law, University of Copenhagen. Her research is centred on criminology and digital youth crime, in particular on perpetrators sharing intimate images non-consensually within different sharing environments. The empirical focus revolves around online ethnography and qualitative single interviews, and in specifics for her $\mathrm{PhD}$ project, she investigates Danish foreign fighter returnees from a narrative, criminological perspective.

Riikka Kotanen is a lecturer in criminology at Middlesex University. She has a $\mathrm{PhD}$ in sociology from the University of Helsinki. Her academic interests are in criminology, victimology and the sociology of law, as well as the interplay of criminal justice and social policy. Her research explores the legal regulation and control of violence in the private sphere, particularly intimate partner violence and parental violence against children, the position of the crime victim within the context of Finnish criminal justice policy, and sexual crimes.

Mette Lovgren works as a Researcher in the Section for Youth Research at Norwegian Social Research (NOVA), Oslo Metropolitan University. She has a PhD in Professional Studies from the Centre for the Study of Profession at Oslo Metropolitan University and a master in sociology from the University of Oslo. She is involved in survey-research into the well-being of children; Ungdata junior and Children's Worlds. She also works with projects about 
violence and sexual abuse through NOVA's Domestic violence research program. Løvgren is member of the editorial board of Norsk sosiologisk tidsskrift.

Trond Martinsen has a master in Welfare Management, and works as a Senior Adviser in the Supplemental Education Department at the University College of Norwegian Correctional Service. He has long experience as a social worker in a high-security prison where he worked with young people, drug problems and aftercare. His research interests are young people and their way through the criminal justice system. Martinsen works within a qualitative tradition. He draws on the research arranging courses and conferences within the field, and recently in the production of a film developing tools for employees working with youths in prisons.

Johanna Niemi (Niemi-Kiesiläinen), Minna Canth Academy Professor, Professor of procedural law, University of Turku. Niemi has worked as a professor at the Universities of Umeå and Helsinki and as Visiting Professor at Lund University, Sweden. She is Doctor Honoris Causa at Uppsala University and has been Fulbright scholar at the University of Wisconsin, Madison Law School 1997-1998. Niemi was member of the Scientific Committee of the EU Fundamental Rights Agency 2013-2018 and Academy of Finland Research Council for Culture and Society 2016-2018. She leads the research project ASLA: Actors, Structures and Law (2015-2019). Niemi's research interests include criminal procedure, consumer insolvency, human rights and the construction of gender in legal discourses. Among her publications are Nousiainen et al. (eds), Responsible Selves. Women in the Nordic Legal Culture, 2001 and Svensson et al. (eds), Nordic Equality at a Crossroads. Feminist Legal Studies Coping with Difference, 2004.

Gabriella Nilsson is an Associate Professor in Ethnology at Lund University, Sweden. Her research focusses on discourses and antagonistic conceptions of gender and violence in contemporary history, as expressed in politics, research and debate. Presently, she studies intersectional narratives of rape in news reports during the period 1990-2015. She is a co-editor of the recently published book Rape Narratives in Motion (Palgrave Studies in Crime, Media and Culture, 2019).

Monika Grønli Rosten is a Senior Researcher at the Norwegian Social Research (NOVA), Oslo Metropolitan University. Rosten has a PhD in Social Anthropology from the University of Oslo. Her doctoral thesis is about place, belonging and territorial stigmatisation, based on ethnographic fieldwork among young adults of multicultural urban areas of Oslo. Rosten's main fields of research are urban marginality and youth culture, parenthood and family, domestic and sexual violence, and her research revolves around questions of social integration and ethnic, religious and, LGBTQ and sexual minorities within the context of the Scandinavian welfare state. 
Laura Marie Schierff holds a Master in Sociology from University of Copenhagen and has wide experience with criminological research from University of Copenhagen, Aalborg University, The ROCKWOOL Foundation Research Unit and the Danish Crime Prevention Council. Schierff is one of the authors of the largest Danish victimisation survey on sexual victimisation and she has contributed as an expert to developing prevention initiatives targeting sexually transgressive behaviour among the Danish youth. Her latest publications concern sexual violence, especially the perspectives of the individuals committing sexual transgressions.

Rannveig Sigurvinsdóttir is an Assistant Professor at the Department of Psychology, Reykjavik University. Her research focusses on violence and trauma, such as the impact of sexual violence and intimate partner violence on survivors. She has published work on the impact of post-assault disclosures of sexual assault on survivors, the mental health of sexual minority sexual assault survivors, the safety and well-being of survivors of intimate partner violence as well as community and legal interventions for trauma victimisation.

May-Len Skilbrei is Professor at the Department of Criminology and Sociology of Law at the University of Oslo as well as holding a position at Norwegian Social Research (NOVA) at Oslo Metropolitan University. Her research interests are gender, sexuality, power and law and she has published books, articles and chapters internationally on how Nordic governments and civil society actors approach prostitution, human trafficking, child sexual abuse and sexual violence.

Elisabeth Staksrud is Professor at the Department of Media and Communication, University of Oslo, Norway. Her research interests evolve around children and online risk, regulation and rights, online censorship and governance, and research ethics. She is in the management group of the 33country EU Kids Online project (www.eukidsonline.net) and a former Harvard Berkman Center Research Fellow. Her books include Children in the Online World: Risk, Regulation, Rights (Routledge, 2016), Digital Mobbing [Cyberbullying] (Kommuneforlaget, 2013) and Towards a better Internet for Children (O’Neill, Staksrud and McLaughlin (ed.), Nordicom, 2013).

Kari Stefansen holds a $\mathrm{PhD}$ in sociology and is a Research Professor at Norwegian Social Research (NOVA) at Oslo Metropolitan University. Here she is in the management group of a ten-year research programme on domestic violence. She was affiliated with The Norwegian Centre for Violence and Traumatic Stress Studies from 2016 to 2018. Her research interests include ideas and conceptualisations of sexual violence, the scope and measurement of sexual violence in the youth population, and social patterns in victims' labelling practices. A current project is aimed at understanding how victims of sexual violence experience and articulate coercive circumstances relating to the assaults they describe. 


\section{Preface}

This book has been made with an aim to both strengthen Nordic conversations about rape and other forms of sexual harm and strengthen international conversations about the Nordic region. The idea for the book grew out of collaborations and events organised by the Nordic Network for Research on Sexual Violence and we were lucky to receive economic support for organising a writer's workshop, language editing and open access by the Scandinavian Research Council for Criminology and Oslo Metropolitan University, and administrative support from the Department of Criminology and Sociology of Law at the University of Oslo. 
$\because$ Taylor \& Francis

Taylor \& Francis Group

http://taylorandfrancis.com 


\title{
1 A Nordic research agenda on rape and sexual violence
}

\author{
May-Len Skilbrei, Kari Stefansen and \\ Marie Bruvik Heinskou
}

\section{Introduction}

How best to prevent and prosecute rape, and to protect its victims, is debated in countries across the world. Rape has also become a central topic in supranational forums such as the United Nations and the European Union and is something that mobilises transnational civil society organisations such as Amnesty International and Equality Now. The issue has also spurred engagement on an individual level, as is evident in how the \#MeToo movement that gained momentum in 2017 brought the world's attention to rape and other forms of sexual harm.

This high level of attention reflects both an increasing awareness of the harm of rape throughout the last few decades and real or perceived changes in the extent and characteristics of the phenomenon of rape. Several countries are currently experiencing an increase in reported cases of rape. Since increased attention towards and understanding of the phenomenon affect identification and people's willingness to report, this increase does not necessarily mean that more people are victimised than earlier. But it does make rape into a phenomenon that policy-makers have to address. The large numbers of reported cases and the notable gap between these cases and convictions are something that, together with the visibility of personal experiences of violation found in social media, are key to the current debates and to opportunities for action.

That rape and other forms of sexual harm are taken seriously is not only something that has arisen from current developments. This story has been a long time in the making. Following the publication of Susan Brownmiller's radical interpretation of rape in her 1975 book Against Our Will and other interventions at the time, women's movements throughout the world have directed our attention towards female victimisation and have offered a gendered analysis of the reason such victimisation exists and why governments have not done more to combat such victimisation. Since the book's publication, rape and other forms of sexual harm have become thoroughly associated with male perpetration and female victimisation; such acts have been interpreted not only as attacks on individual women but also as attacks on women as women. Most of the chapters in the present book are influenced by such understandings of rape 


\section{May-Len Skilbrei et al.}

as a social phenomenon, with causes and effects which reach far beyond the people who are directly affected by such acts.

Female perpetration and male victimisation continue to be less debated and researched than other forms of rape. Police statistics continue to represent rape mainly as something that men subject women to. Now that we are aware of the problems of building our understanding of the phenomenon on figures that easily reproduce what is already taken to be true (and therefore are more easily identified and reported), calls to open debates and research to cover male victimisation have grown stronger (see Javaid, 2018; United Nations, 2018). While most of the examples covered in this book offer analyses of various aspects of male perpetration and female victimisation, some of the chapters also present discussions of the consequences gender has for how we understand rape.

While rape in many countries is defined as a physical assault and is often seen as a particularly harmful form of sexual violence, research in many contexts has demonstrated that treating rape as separate from other acts is problematic for two reasons. First, sexual harm is represented along a continuum, where the severity of the acts differs but shares key factors and consequences (Basile, 1999; Salfati \& Taylor, 2006). Second, research demonstrates that to separate rape from other acts and crimes is difficult for the people involved, including witnesses and police, which means that to sharply separate rape from 'rape-like' or 'grey zone' acts means that we miss a great deal of information about why and how rape occurs.

Following this notion, the present book is about rape in the wider context of other types of sexual harm. The need to understand rape in a wider context, where other sexual and violent acts are not easily separated from rape, is also important in light of how rape itself is a highly contested issue (Conaghan, 2018; Reitan, 2001). The meaning of the concept has changed historically and varies across and within countries. Different and conflicting conceptualisations may co-exist and cause confusion about the boundaries of the phenomenon, for instance, when legal and lay understandings are different. Rather than departing from one authoritative definition of rape, the authors in this book explore rape as a contextually and historically situated occurrence and offer insight into the complexities of addressing the issue for those affected, both in research and at the societal level. This approach also means that we include other forms of sexual violence or assault than rape in the book, including phenomena located in the 'grey area' between rape and sex (Gavey, 2013).

These developments and controversies create a need for research. Because debates feed on numbers, a key topic of research to date has been the development of better tools to assess the scale of the problem and to understand more about who is affected, and why. The fact that those in the field have difficulties in agreeing on definitions and perspectives implies that we also require the discursive means to understand the problem and those affected, as well as the responsibilities of societies to confront the problem. At the same time, these same characteristics place great responsibility on researchers to be very clear about their theoretical positions and the limitations of their findings, and to 
ensure that their findings are not misrepresented in ongoing debates. While clear transnational and global trends exist in how rape is understood, approached, and researched, we argue that the necessary methodological, theoretical, and epistemological development of the rape literature needs to be grounded in national and regional manifestations in the form of concrete empirical studies. This book is an attempt to explore methodological, theoretical, and epistemological issues, using the case of rape in the Nordic countries as a starting point. In this way, the book's authors offer insights into the literature and on continuities and change in the Nordic context.

\section{The Nordic context}

The Nordic region is a particularly interesting case for the exploration of rape and other forms of sexual harm as both a personal and a socio-political issue. For several decades, the region has often been portrayed as being 'best in its class' in ensuring equality and social protection to its population. The Nordic countries are generally associated with a strong welfare state - what Gøsta Esping-Andersen in 1990 termed the 'social democratic welfare regime' - and the merits of this way of organising society and state-citizen relations continue to attract international attention (McKowen, 2018). As mentioned above, women's movements in the last few decades have offered an analysis of rape as something that is caused by and has consequences for much more than the people who are directly involved in a given case of rape. This situation has meant that policies that were designed to assure greater gender equality are also widely thought to serve to prevent rape and other forms of sexual harm. This link has also been made in the Nordic countries, and the institutionalisation and success of the region's gender-equality policies have received international praise (Borchorst, 1999). The Global Gender Gap Report (World Economic Forum, 2018) from 2018 places Iceland, Norway, Sweden, and Finland in the top four positions (in that order), while Denmark is in 13th place. Not only is gender equality something that the individual Nordic countries have strongly emphasised over the last few decades; ensuring gender equality has also been prioritised and harmonised at the regional level, through strong collaborations between the various countries on several platforms. The Nordic Council of Ministers, for instance, sees gender equality as a 'key area of co-operation for the Nordic countries'.

The fact that the Nordic countries are generally, but not uniformly, oriented towards gender equality is often presented as the result of an alliance between feminism and the state and as an alignment of the concerns of civil society and the state. The alliance and alignment between feminism and the state are expressed by Helga Hernes's term 'state feminism', from her 1987 book Welfare State and Woman Power: Essays in State Feminism. This link secures support and disciplines the state into mainstreaming gender into the state's various policy areas and governmental branches. This situation is often considered a feminist victory, but what is less often discussed is how this alliance and alignment have also disciplined feminist activists in how they prioritise causes 
and protest. A central aspect of Nordic feminism is that it has very explicitly turned to criminal law as an instrument for achieving gender equality (Burman, 2010), and acts such as rape are commonly viewed as the result and expression of gender inequality but also as an attack on and something that is detrimental to gender equality.

To investigate rape in the Nordic countries is thus also to investigate the foundation and consequences of Nordic gender equality. The Nordic countries are often presented as a coherent region in terms of welfare orientation, statecitizen relations, and gender equality. At the same time, great differences exist between the five Nordic countries, both in the centrality of gender equality as a stated goal and in how the individual countries approach rape and other forms of sexual harm. To draw together analyses from all the Nordic countries therefore invites a comparison between contexts that, from the outset and from the outside, look very similar, but when looked at more closely, they have several important differences.

There are also other reasons to problematise the imagery of the Nordic countries as being uniform and consistent in their prioritisation of gender equality. Researchers have questioned whether the region really is special, or at least if it is still special (see Liinason, 2018; Witoszek \& Midttun, 2018). While the Nordic countries may not be as exceptional and uniform as they are often presented, ideas about Nordic coherence and the continuing prioritisation of gender equality are central to national identities in the region (de Los Reyes, 2017; Tham, Rönneling, \& Rytterbro, 2011). The Nordic Council of Ministers, for instance, presents gender equality as one of the aims of its collaborative efforts: 'Successful Nordic co-operation on gender equality can not only help us increase gender equality in our own region, but also help to ensure the strong profile of the Nordic region internationally on gender equality' (Nordic Council of Ministers, 2019, p. 5).

Gender equality policies are not the only internationally acknowledged side of the priorities and orientations of the Nordic welfare states. These nations are also known for humanitarian penal policies that stand in contrast to developments in many other Western countries in the last few decades. Low levels of punishment, penal innovations designed to protect vulnerable groups from the negative consequences of imprisonment, the widespread use of 'open' prisons, the existence of humane prison conditions, and an elaborate system of transition from prison to ordinary society have all earned the region a reputation for 'penal exceptionalism' (Pratt, 2008). While some (e.g. Ugelvik \& Dullum, 2011) have critiqued the conclusion that Nordic societies are less punitive and that punishments are more humane, the levels of punishment are low in relation to other European countries - with one notable exception, the punishment for sex crimes. In the last two decades, several of the Nordic countries have changed their rape legislation and punishment levels considerably. Denmark, Finland and Norway currently have similar formulations of the crime of rape in their penal codes, as they all emphasise violence and coercion (Jacobsen, 2019, p. 48), while Iceland and Sweden both revised their respective acts in 2018 to criminalise the lack of consent rather than the presence of violence or coercion. 
The willingness to punish sex crimes seems to make such crimes an exception to the Nordic or Scandinavian penal exceptionalism (Tham, 2001). The position of the women's movements in the region and the strength of women's political mobilisation and representation (for an analysis, see Borchorst \& Siim, 2008) are also relevant sides of the context. In their priorities, the women's movements have expressed what the criminologist Kristin Skjørten (1996) has called 'legal optimism', i.e. an overly strong belief in what criminal law can accomplish. One could argue that the low thresholds of sex-crime legislation and the breadth of acts that are criminalised as sexual harm were enabled by decades of feminist investment in changing understandings of the relationship between public and private and between the state and its citizens. Matters that are typically considered private elsewhere are more often treated as being within the scope of the state in the Nordic countries (Borchorst \& Siim, 2008).

Bearing in mind the great investments that have been made in the Nordic countries to counteract sexual harm and to establish gender equality, it appears paradoxical that phenomena such as rape continue to pose a challenge to policy-makers. Figures of police-reported rape and figures from populationbased surveys indicate that rape affects a considerable part of the population in the Nordic region (Heinskou, Schierff, Ejbye-Ernst, Friis, \& Liebst, 2017; Swedish National Council for Crime Prevention, 2017; Thoresen \& Hjemdal, 2014). The number of cases of rapes reported to the police has increased in the region, with the increase particularly evident in Sweden. Because Sweden, in many areas, has what is often considered the most progressive policies on gender equality, but also on sexual violence, in the region, it also appears paradoxical that the nation consistently shows higher figures for reported sexual victimisation than the other Nordic countries (Tham et al., 2011, p. 587). While this situation does not mean that levels of victimisation in society are higher or increasing, the increase in registered numbers of rape in the Nordic region has attracted attention internationally (see, for example, Fox News, 2017).

The Nordic approach to rape also shows other paradoxes. While people in the region have paid attention to the power and role of law in combatting rape, they have paid less attention to the issue of which other steps can be taken to prevent rape and to promote desistance among perpetrators. Services are available for both victims and perpetrators that may also serve to prevent trauma, revictimisation, and re-perpetration, but such services are not comprehensive and systematic throughout the region or within each country. One may suspect that this is a case where criminal justice approaches have been prioritised and that they often overshadow other policies.

For these and other reasons, rape and other forms of sexual violence are currently high on public agendas throughout the Nordic region, especially in Denmark, Norway and Sweden. Fears over high figures and high levels of attrition through the criminal justice process are often debated in terms of a need for legislative revisions. Overall, ideas about rape and sexual violence and the appropriate responses to these issues seem to be changing in interesting ways in this region. While changes are also happening elsewhere in Europe, there are 
reasons to consider the ongoing changes within the Nordic region as being related to each other and linked to broader developments in terms of penal cultures, welfare state retraction and expansion, gender equality policies, and public-private partnerships.

These factors make this a particularly important time to look at rape in the Nordic countries from different angles. Based on this background, the authors in this book illuminate the phenomenon and construction of rape and other forms of sexual harm within the Nordic region, as well as on how they are addressed through social policies and in legal systems. The aim is to fertilise both the international scholarship on sexual violence and the scholarship on the Nordic region. The chapters in this book have been arranged based on our ambition to cover a broad area. The structure and content of the book will be described in greater detail below; first, a note on terminology.

\section{A note on the 'victim' label}

In a recent article on the social risks of labelling, telling and reporting sexual assault among college students in the USA, Khan, Hirsch, Wamboldt, and Mellins (2018) caution against understandings of rape that are organised around identity categories such as 'survivor' and 'perpetrator', as 'such words suggest a kind of person rather than an act or experience' (p. 453). And further, because these words encompass so much they 'may serve as impediments to people making sense of their experiences or getting the kinds of help that they need' (p. 453). Their point is that there is not a one-to-one relationship between experiencing rape and taking up a survivor or victim identity; rather, people who experience rape will often shy away from these labels and associated identities. We can infer from this idea that researchers should focus on the experience of rape rather than on the person who has been raped. The authors draw a parallel to how the phrase 'men who have sex with men', which was coined by HIV activists two decades ago, makes no assumptions about the sexual identity among this group of men but simply describes a sexual practice. This line of argument also points to the political aspect of labels and concepts, and to how labels that describe experiences rather than identities may contribute to the removal of stigma. Another example could be the shift from talking about crippled or disabled people to talking about people with disabilities.

Khan et al.'s (2018) position could be viewed as being rather radical in the general rejection of what they see as identity labels. Other researchers (for an overview, see Hockett \& Saucier, 2015) do not problematise identity labels as such but do favour one over the other: most often the 'survivor' label or the combined 'survivor/victim' construction over the 'victim' label. These researchers' argument is that the 'victim' label, as an identity label, signifies something weak, fundamentally broken and powerless. The term 'survivor' is typically applied to encompass the serious ramifications of sexual violence but also to empower those who are affected (see, for example, Williamson \& Serna, 2018). 
Labels matter, of course, not only in the sense that they are problematic to their holders but also by how they have implications for problem understandings and decision-making related to solutions. The editors of this book have not instructed the authors to apply a particular terminology; the authors have applied concepts and labels that fit with the aims and materials of their particular chapters. In the chapters on law and the penal process, the parties involved are thus labelled according to their status in the case, for example, as the 'complainant' and the 'assailant' or 'accused'. In other chapters, the authors use different labels, and in some chapters, they avoid labels altogether.

Taken together, the chapters demonstrate that default political and perhaps ethically motivated positions on labelling people who are involved in rape and other forms of sexual assault are problematic. The victim label may mean and do different things within different frameworks. From some perspectives, the victim label makes sense and is productive, while from other perspectives, it is problematic. Researchers should therefore be mindful of the broader framework and positioning of their studies and how different labels fit their particular scholarly projects.

\section{The content of the book}

This book is designed to represent the whole Nordic region and to take up topics that are particularly timely in the region and beyond. The specific context of the Nordic region needs to be taken seriously. At the same time, the authors also demonstrate that Nordic experiences have shown that some themes and developments are more general, rather than being particularly Nordic. We believe the readers of the book will be struck by the similarities between the region and elsewhere in terms of the manifestations, policies and debates on sexual violence. The book offers new research on perpetrators, victims, criminal justice and prevention, and at the core of the theoretical discussions in the book are issues such as consent, power, sexual ethics, boundary making and victimhood and perpetrator constructions. The chapters speak to the great interest in delineations and definitions (and therefore also in attempts to estimate the extent of victimisation) as well as the challenges that digitalisation poses to efforts to prevent, detect and prosecute rape and other forms of sexual harm.

The book addresses four key sets of questions related to rape and other forms of sexual harm. The first is theoretical and methodological questions related to how we can understand and study rape; the second is the role of criminal law; the third how we can best understand perpetrators; and the fourth is the role, character and consequences of the digitalisation of rape and other types of sexual harm.

\section{Part 1: understanding, delineating and studying rape}

The first part consists of four chapters that in different ways address questions of how rape is studied. A key question in both political debates and scholarship 
is how rape can be appropriately defined and delineated from other acts and situations. Ideas about rape have never been constant. Reconceptualisations of rape have a long history, from rape being a property crime that men commit against other men - i.e. the theft of their women's sexuality or honour (McGlynn \& Munro, 2010, p. 1) - to an affront to women's modesty, to the sexual integrity and freedom arguments that today are central in international fora but also within many other jurisdictions. The definition of rape as an attack on the person is thus a rather new construction.

Based on this background, Conaghan (2018) has argued that the manifold ideas about what rape is, why it happens and the harm it causes make it impossible to talk about an essence of rape, a constant across time and space. Other scholars have taken a different position, arguing that rape can be distinguished from other sexual acts by different normative criteria, most commonly by referring to rape as an undermining of sexual autonomy or integrity (see, for example, Cahill, 2001). This notion means that the improvement of our capacity to study rape is also a thoroughly theoretical endeavour when addressing questions that initially appear practical in nature. The chapters in this part of the book offer inroads to further our understanding of how rape and other forms of sexual harm can be understood as being produced by and located in the social - in relations, situations, and cultures.

The first chapter in this part of the book investigates how theories of gender are applied in the study of sexual violence within intimate relations. Margunn Bjornholt is the author of the chapter 'Theorising sexual violence in intimate relations in Scandinavia: A literature review', which focusses on the theoretical frameworks that have informed empirical research on sexual violence in the Scandinavian countries to date, with the aim of mapping out a landscape of theoretical positions. Her starting point is that although a given research field may be international, theorisation also occurs in the national and regional contexts where scholars live, work, and think. The chapter provides analyses of five recent publications by Danish, Norwegian, and Swedish authors representing different key positions. The review reveals the theoretical diversity and innovation in making sense of sexual violence among Scandinavian scholars, as well as the continued relevance and theoretical potential of a renewed involvement with different strands of feminist theorisation.

The theoretical exploration in Bjørnholt's chapter is followed by a chapter by Monika Rosten titled 'Cultivating ethical negotiations or fetishising consent in BDSM?', which addresses bondage, discipline (or domination), sadism and masochism. In this chapter, Rosten explores negotiations about consent in the BDSM context. Ideal BDSM play is based on consent. The parties establish agreements about roles and transgressions and their absolute boundaries. Rosten analyses a case that started out this way, but where the dominance play escalated to encompass most of the everyday life of the submissive partner, Tina. Tina was conflicted about the relationship and how she had consented to being dominated in ways that were impossible to escape, and she wondered if she had been exposed to partner violence rather than BDSM play. This case led Rosten 
to further investigate the boundaries of consent as she interviewed other BDSM practitioners. Her analysis reveals how consent is fetishised in the BDSM community in ways that make it possible to see how unequal power relations play into seemingly sound negotiations and relationships.

The difficulties in delineating between sexual violence and legitimate sexual acts are followed up in Chapter 4, 'Understanding unwanted sexual touching: A situational approach'. In this chapter, Kari Stefansen explores the phenomenon of unwanted sexual touching, arguing that the topic provides insight into the boundaries of sexual violence. Using written descriptions of unwanted sexual touching from young women (18- to 19-year olds) drawn from a survey study, she demonstrates the unstable and fleeting character of unwanted sexual touching. Such touching takes on different meanings in different social situations and is also dependent on the relationship between the people involved: sometimes an aggressive act, at other times unwanted. Stefansen argues that incidents of unwanted touching are problematic even when they are not experienced as being sexual intrusions, as they may contribute to a diffuse 'phenomenology of fear' among girls and women: the embodied knowledge that their right to bodily integrity is less protected than that of boys and men.

The three chapters taken together illustrate well the instability of the term 'rape' and the difficulties involved in separating rape from the characteristics of relationships, situations, and contexts. This instability makes empirical research very difficult, not least when depending on people's own definitions and delineations when undertaking surveys to produce knowledge on the extent of rape. In Chapter 5, 'Making the case for 'good enough' rape-prevalence estimates: Insights from a school-based survey experiment among Norwegian youths', Kari Stefansen, Mette Løvgren and Lars Roar Froyland illustrate some of the difficulties in measuring rape in population surveys. As Krebs (2014) has done, they argue for a dual approach to rape-prevalence estimates: that researchers should pursue both 'best' and 'good enough' procedures. Their own analysis addresses rape estimates based on survey studies among youths in the school setting. Drawing on a survey experiment that was set up within a Norwegian school-based study, they conclude, in line with international scholarship, that wording is crucial and that the asking of behaviourally specific questions leads to higher rates of rape than the use of general questions, which holds for both genders and for different social groups. They argue that among youths and for the purpose of tracking developments in the prevalence of rape over time, simpler 'good enough' measures are indeed useful.

\section{Part 2: the formulation and role of criminal law}

Changes over time in how rape is delineated, explained and discussed shift which approaches seem just and sustainable. If rape is seen as something that exists due to a combination of male sexual drive and lack of self-discipline, then doing something about either or both of these factors may seem like a viable solution. If one instead regards rape as an act that is committed due to 
a perpetrator's own psychological trauma or disposition, then therapy will appear to be a sound way forward. Criminal law operates at the nexus of both explanations. The law defines the conditions under which an individual is culpable, but the reasoning behind something being defined as a crime may still be built on an understanding of the act being premised on particular ideas about sexuality, gender and power inequalities. Several of the chapters in this book address legal responses to rape in the Nordic countries, which is an important strand of Nordic scholarship on rape: something that perhaps reflects that legal strategies have long been the priority of both Nordic governments and of women's movements. But how criminal law defines and penalises rape and other forms of sexual harm has been a key focus for political and scholarly debates in many European countries, as is evident in ongoing discussions about whether the harm of rape is best expressed by criminalising the presence of violence and coercion or the lack of consent. Several authors address how criminal law addresses rape and other forms of sexual harm. While criminal law typically positions the perpetrator in the centre of the criminal justice process, the last few decades have seen powerful protests against the invisibilisation of the victim. As a result, victims' rights in the criminal justice process have changed substantially since the 1990s, both in the Nordic countries and in many other contexts.

Part of the question of how to define rape is the question of who can be raped. In many countries, sexual violations that take place within marriage are exempt from the definition of rape, either in the law itself or in practice. One priority of 1970s feminism was to bring violations that take place in the home to the attention of politicians and to make sure that such crimes were illegal, on par with physical and sexual crimes that take place between strangers (Skjørten, 1996). Riikka Kotanen's chapter, 'From the protection of marriage to the defence of equality: The Finnish debate over the sexual autonomy of wives', addresses this issue by investigating the process and debates that led to a universal rape prohibition in Finland in 1994. She looks particularly at how debates emerged and played out and then places these debates in the larger Nordic context, concluding that Finland was particularly late in recognising the sexual autonomy of wives. Kotanen discusses possible reasons that a marriage exemption in rape law was widely seen as legitimate in Finland, and she points to how feminist campaigners in the end managed to shift this understanding. This chapter thus explores a legal reform two decades in the making and looks at the interaction between the law-revision process, ongoing public debates and the role of the sanctity of family and home in Finnish culture.

At the end of Kotanen's chapter, she points to emerging debates in Finland about the revision of rape law to criminalise the lack of consent. Such revisions have been debated throughout the region, not least after Sweden revised its own act on the subject in 2018. The Nordic countries frequently collaborate on gender-equality issues and often look to each other when designing their own national approaches. In the chapter 'Towards voluntariness in Swedish rape law: Hyper-medialised group rape cases and the shift in the legal discourse', Gabriella Nilsson analyses the trajectory of Swedish debates on rape law in the 
period 1990-2015. This was a period in which rape law underwent major revisions designed to solve problems in prosecuting rape as well as in expressing understandings of the harm of rape. A long line of revisions has also taken place in several of the other Nordic countries, which demonstrates both a political willingness to look for better solutions and uncertainty in how to best define rape. In Nilsson's analysis of the particular case of Sweden, she finds that the debates that have followed after particularly attention-grabbing cases of rape seem to have affected debates about rape legislation, and later reform, throughout the period. The chapter therefore highlights the role of the media and how concerns about rape have been energised by fear of migrants and by the future of a sustainable welfare state.

Over the last few years, Sweden and other countries have witnessed several debates about the question of which definition of rape is most appropriate, both in the practical and symbolic senses. The Nordic countries have all signed the Council of Europe Convention on preventing and combating violence against women and domestic violence, which explicitly describes rape as a situation with a lack of consent. Current debates revolve around whether consent-based laws or coercion-based laws can better encompass how power affects sexuality and personal relations. Helena Jokila and Joanna Niemi discuss this debate in their chapter 'Rape law and coercive circumstances', in which they problematise the assumption that consent-based rape law will solve the current problem many countries face in their ability to prosecute rape. Jokila and Niemi analyse selected rape cases from the Finnish Courts of Appeal and compare them with Canadian convictions; in doing so, they demonstrate that evidentiary questions and considerations for the most part are the same across jurisdictions. The authors argue that attention should be directed towards ways of making rape laws include contextual factors, and they point to how rape laws can be thoroughly revised by looking to definitions applied in the International Criminal Tribunals for Rwanda and for the former Yugoslavia.

Paying attention to law not only involves looking at how the perpetrator in cases of rape is investigated and punished; such attention also entails looking at how the injured party, the victim, is treated throughout the criminal justice process. Hildur Fjóla Antonsdóttir's chapter in this book, 'Empowered or protected?: The 'problem' of complainants' rights in Danish and Norwegian preparatory works on criminal procedure', analyses how victims and victims' rights are represented in Danish and Norwegian preparatory work, including hearing procedures. As mentioned above, the victim's role in the criminal justice process is mainly to serve as a witness for the prosecution. The last two decades, however, have seen victims gaining more rights to be active parts of the process. This change has been received differently in various contexts, and Antonsdóttir demonstrates that such differences in views have also been expressed within the Nordic region. She finds that while Norwegian preparatory documents' discussions of increasing rights to participation and inclusion for victims have mainly been framed as empowering victims (and thus realising their citizenship rights), the Danish documents frame such discussions as a threat to 
the rule of law and to the victim. Antonsdóttir argues that one reason for this situation is that the injured party is mainly treated as a citizen in the Norwegian documents but mainly as a victim in the Danish documents. In this case, being defined as vulnerable and in need of the state's protection makes the receipt of full inclusion difficult for victims.

\section{Part 3: perpetrator and perpetration constructions}

Research on rape often focusses on the people who are subjected to rape and investigates the phenomenon from their perspective. While there are good reasons for considering what rape entails for victims to be a key topic in research (Alcoff, 2018), we argue that the field needs more investigations of the perspectives of perpetrators. For long periods in history, and in diverse geographical places, rape has been defined as a matter of male sexual urges (see, for example, Fradella \& Fahmy, 2016). In this understanding, rape is a matter of men acting on a biological disposition. This understanding does not mean that, in such periods, rape has been defined and treated as inevitable, in the sense that perpetrators have been exempt from blame and punishment. During such periods, the reactions from others and from the authorities are typically based on condemnation of the lack of ability to control one's urges in the perpetrator, having committed a crime due to lack of self-discipline.

More psychologically based explanations became important at the end of the 19th century. In this perspective, rape and other forms of sexual violations came to look like crimes linked to psychological trauma and disposition; treatment and incapacitation, depending on how deterministic the diagnoses were, appeared to be the most viable solutions. Not least as a result of various feminist campaigns, the last four decades have seen rape turned into a matter for sociological interpretation, where the reasons are sought in gender relations, power dynamics, and sexuality constructs. This change does not mean that biological and psychological explanations have disappeared but that they are complementary and competing, depending on the characteristics of the crime and on the context.

This book includes several chapters that specifically discuss situations where sexual violations, including rape, occur. Two of these chapters are included in part 3 , as they address norms that inform how perpetrators reason. The shifts in interpretative frameworks described above also inform more lay reasoning on how committing rape and other forms of sexual harm is related to existing norms and other acts. Individualistic psychological explanations easily end up positioning the rapist as someone who is in breach of normative masculinity and sexuality, while more sociological understandings frame rape differently. It is easy to see that such shifts in our understanding of why someone commits rape mean that during some periods, the act looks like a continuation of normative masculinity and social relations, while during other periods, such acts constitute a breach with the norms and practices of masculinity.

In Chapter 10, 'Othering the rapist: Rurality, sexual violence and the Bjästa case', Lucas Gottzén and Anna Franzén explore such normativity based on 
an empirical study of the implementation of a school-based preventive programme. In this programme, students were presented with a concrete case of sexual violence that they then discussed with their teachers in class: the Bjästa case. The programme that Gottzén and Franzén studied particularly thematised gender and bystander responsibility. The authors found that the meanings the students drew from the programme were different from what it was designed to do. Instead of utilising the case presented in the programme to reflect upon normative sexuality and gender, they instead distanced themselves from the case. This distance was possible due to how rurality holds a particular meaning, and the students explained what happened in the case by how, in the rural community in question, the perpetrator and the community were different from what the students considered to be the norm. This outlook meant that the programme reinforced the students' stereotypes about places and people rather than enabling them to reflect on rape and individual responsibility in the face of rape.

While sociological explanations of why rape occurs often emphasise how the act of rape is best understood if we relate rape to acts that are legal and legitimate, it is easy to understand resistance to an association between one's own actions and relations with rape. In Chapter 11, 'Sexual transgressing: Situational and narrative perspectives', Laura Marie Schierff and Marie Bruvik Heinskou investigate situational descriptions of sexual transgressions from the perspective of the transgressor. The authors conducted qualitative interviews with young men who, in their own words, had committed sexual transgressions. Based on the men's descriptions of the situations where these acts had occurred, the authors discern situational logics or patterns that may help us understand why these acts occurred. Schierff and Heinskou present accounts of situations and explore what these accounts, or narratives, do for how the transgression is understood. The first account is a framing of the transgression as the result of alcohol intoxication, which means that the men positioned themselves as not being themselves in the situation. The second narrative explains the transgression by misunderstandings of the signals of consent and the absence of consent.

While both explanatory narratives are also excuses, it is valuable to take them seriously as narratives that enabled the men to integrate what they had done without such integration necessarily changing how they looked at themselves. Understanding such mechanisms is important if we are to understand why rape and other types of sexual harm are committed, but also why perpetrators, victims, and bystanders do not necessarily acknowledge such transgressions as something that should be acted upon.

\section{Part 4: the digital dimension}

The fact that more and more areas and aspects of life have become digitalised poses challenges to the definition, detection, and prosecution of sexual violations, including rape. The book includes three chapters that illustrate this development. The first chapter in part 4 examines how online abuses challenge traditional ideas 
and approaches to the phenomenon of rape, the second analyses the importance of digital arenas for perpetrator dynamics, and the third explores the role and structure of online disclosures of rape and other types of sexual harm. All three chapters address thresholds in one way or another: thresholds for how society, perpetrators and victims recognise acts as problematic.

Acts of sexual exploitation and abuse that happen online and via mobile phones have gained a great deal of attention in recent years. Such cases are also beginning to reach European courtrooms. Chapter 12 presents one such case. In the chapter 'Rape in the age of the Internet', Elisabeth Fransson, Trond Martinsen and Elisabeth Staksrud analyse a case where a young man named Alex is convicted of over one hundred counts of rape that took place via the Internet and mobile phones. He manipulated, and later threatened, young people into sharing pictures and engaging in sexual acts in front of a camera that they themselves controlled. The fact that the perpetrator and the victims did not meet and that the acts did not physically involve Alex was challenging to handle within the scope of existing law and case law, but this case entailed a careful translation of meaning and consequences from more traditional accounts of rape to digital arenas. Alex, his victims, and the court all struggled with how to understand and react to what had happened, and while Alex acknowledged that his acts were problematic, he was unable to free himself from an understanding of rape as something that involves direct physical threats and sexual encounters. This chapter thus adds to the literature on rape both by presenting an analysis of a development that is quite new and by illuminating something that also happens in other cases: namely that the situations and relations in which abuses occur may look very different for the various people involved.

The fact that situational factors affect how rape and other forms of sexual harm are interpreted and reacted upon is not surprising, but what mechanisms are involved? In Chapter 13, 'Digital sexual violence: Image-based sexual abuse among Danish youth', Sidsel Kirstine Harder, Katrine Elmose Jørgensen, Jonathan Priesholm Gårdshus and Jakob Demant analyse the mechanisms behind the non-consensual sharing of sexual images by building on a combination of survey and qualitative data among young Danes. Image-based sexual abuse has been the subject of much attention in the last few years, and the laws, technologies and understandings of the subject are changing. Few empirical investigations into the phenomenon have been conducted to date, however. The authors look to criminological theory to investigate what creates the likelihood of sharing such pictures. They find that poorer self-control is associated with a higher risk of committing image-based sexual abuse, although the effect is moderate and partly mediated through digital, sexual and social opportunities. The chapter offers insights that are important for understanding why such picture sharing takes place, which may help to prevent such activities in the future.

Digitalisation thus may lower thresholds for committing violations and could transform the expression of such crimes. Digitalisation is also a development that affects victims' courses of action. A key theme in the literature on victimisation is that there are many barriers to self-identification as a victim of rape 
and other forms of sexual harm and to disclosing such experiences to others. In Chapter 14, 'Breaking the silence: Social media disclosures of sexual violence in Iceland', Rannveig Sigurvinsdóttir, Bryndís Björk Ásgeirsdóttir and Sara Arnalds explore how online disclosures of rape and other forms of sexual harm play out. They empirically studied the trajectory and content of particular exchanges that took place on online platforms at the same time that particular events and debates were also taking place and being presented in traditional media. The authors analyse this scenario in relation both to what was being disclosed and what reactions these disclosures attracted from other participants within these arenas. They find that patterns of disclosure followed public debate and that those who disclosed received much support, but often the support was of little substance. It is important to understand how the characteristics of online platforms affect disclosure and the relationship between such disclosures and those that take place face-to-face. Does online disclosure serve a similar purpose, or should it instead be understood as a political act of participation in an event? This chapter contributes knowledge to the development of online arenas that can serve as platforms for sharing experiences with violations as well as to the mechanisms that hinder and facilitate disclosure more generally.

We invite readers to delve into these chapters with an open mind in order to understand the various implications that rape has in our modern society, both in the Nordic context and abroad.

\section{Note}

1 www.norden.org/en/information/nordic-co-operation-gender-equality.

\section{References}

Alcoff, L. (2018). Rape and resistance. Cambridge, UK: Polity Press.

Basile, K. C. (1999). Rape by acquiescence: The ways in which women 'give in' to unwanted sex with their husbands. Violence against Women, 5(9), 1036-1058.

Borchorst, A. (1999). Ligestillingsinstitutionerne. In C. Bergqvist, A. Borchorst, A. D. Christensen, N. C. Raaum, \& A. Styrkásdóttir (Eds.), Likestilte demokratier? Kjønn og politikk $i$ Norden (pp. 156-175). Oslo: Universitetsforlaget.

Borchorst, A., \& Siim, B. (2008). Woman-friendly policies and state feminism: Theorizing Scandinavian gender equality. Feminist Theory, 9(2), 207-224.

Brownmiller, S. (1975). Against our will: Men, women and rape. New York: Fawcett Columbine.

Burman, M. (2010). Rethinking rape law in Sweden: Coercion, consent or nonvoluntariness?. In C. McGlynn \& V. E. Munro (Eds.), Rethinking rape law: International and comparative perspectives (pp. 196-208). New York: Routledge.

Cahill, A. J. (2001). Rethinking rape. Ithaca, NY: Cornell University Press.

Conaghan, J. (2018). The essence of rape. Oxford Journal of Legal Studies, 39(1), 151-182.

de Los Reyes, P. (2017). When feminism became gender equality and anti-racism turned into diversity-management. In L. Martinsson, G. Griffin, \& K. G. Nygren (Eds.), Challenging the myth of gender equality in Sweden (pp. 23-48). Bristol: Policy Press. 
Esping-Andersen, G. (1990). The three worlds of welfare capitalism. Cambridge, UK: Polity.

Fox News. (2017). Trump may have been unclear, but Sweden experiencing a migrant crime wave. 20 February 2017. www.foxnews.com/politics/trump-may-have-beenunclear-but-sweden-experiencing-a-migrant-crime-wave (accessed 20 April 2019).

Fradella, H. F., \& Fahmy, C. (2016). Rape and related offences. In H. F. Fradella \& J. M. Sumner (Eds.), Sex, sexuality, law, and (in)justice (pp. 138-182). New York: Routledge.

Gavey, N. (2013). Just sex? The cultural scaffolding of rape. London and New York: Routledge.

Heinskou, M. B., Schierff, L. M., Ejbye-Ernst, P., Friis, C. B., \& Liebst, L. S. (2017). Seksuelle kraenkelser i Danmark: Omfang og karakter. Copenhagen: Det kriminalpræventive råd.

Hernes, H. (1987). Welfare state and woman power: Essays in state feminism. Oslo: Norwegian University Press.

Hockett, J. M., \& Saucier, D. A. (2015). A systematic literature review of 'rape victims' versus 'rape survivors': Implications for theory, research, and practice. Aggression and Violent Behavior, 25(Part A), 1-14.

Jacobsen, J. (2019). Valdtektsstraffebodet: Gjeldane rett og spørsmålet om reform. Bergen: Fagbokforlaget.

Javaid, A. (2018). Male rape, masculinities, and sexualities: Understanding, policing, and overcoming male sexual victimisation. Cham: Palgrave Macmillan.

Khan, S. R., Hirsch, J. S., Wamboldt, A., \& Mellins, C. A. (2018). 'I didn't want to be "that girl": The social risks of labeling, telling, and reporting sexual assault. Sociological Science, 5, 432-460. doi:10.15195/v5.a19

Krebs, C. (2014). Measuring sexual victimization: On what fronts is the jury still out and do we need it to come in? Trauma, Violence, \& Abuse, 15(3), 170-180.

Liinason, M. (2018). Equality struggles: Women's movements, neoliberal markets and state political agendas in Scandinavia. Abingdon, UK: Routledge.

McGlynn, C., \& Munro, V. E. (2010). Rethinking rape law: An introduction. In C. McGlynn \& V. E. Munro (Eds.), Rethinking rape law: International and comparative perspectives (pp. 1-14). New York: Routledge.

McKowen, K. (2018). A welfare 'regime of goodness'? Self-interest, reciprocity, and the moral sustainability of the Nordic model. In N. Witoszek \& A. Midttun (Eds.), Sustainable modernity: The Nordic model and beyond (pp. 119-138). Abingdon, UK: Routledge.

Nordic Council of Ministers. (2019). Nordic co-operation programme on gender equality 2019-2022. Copenhagen: Nordic Council of Ministers. http://norden.diva-portal.org/ smash/get/diva2:1283606/FULLTEXT01.pdf (accessed 20 April 2019).

Pratt, J. (2008). Scandinavian exceptionalism in an era of penal excess. Part I: The nature and roots of Scandinavian exceptionalism. British Journal of Criminology, 48(2), $119-137$.

Reitan, E. (2001). Rape as an essentially contested concept. Hypatia, 16(2), 43-66.

Salfati, C. G., \& Taylor, P. (2006). Differentiation sexual violence: A comparison of sexual homicide and rape. Psychology, Crime \& Law, 12(2), 107-125.

Skjørten, K. (1996). Rettsoptimisme og seksualisert vold. Materialisten, 24(1-2), 21-39.

Swedish National Council for Crime Prevention. (2017). Kriminalstatistik 2016. Anmälda brott. www.bra.se/download/18.5484e1ab15ad731149e3a81c/1490859029793/Samman fattning_anmalda_2016.pdf (accessed 15 May 2019).

Tham, H. (2001). Law and order as a leftist project? Punishment and Society, 3(3), 409-426. 
Tham, H., Rönneling, A., \& Rytterbro, L. L. (2011). The emergence of the crime victim: Sweden in a Scandinavian context. Crime \& Justice, 40(1), 555-611.

Thoresen, S., \& Hjemdal, O. K. (Eds.). (2014). Vold og voldtekt i Norge: En nasjonal forekomststudie av vold $i$ et livsløpsperspektiv. Oslo: Nasjonalt kunnskapssenter om vold og traumatisk stress.

Ugelvik, T., \& Dullum, J. (Eds.). (2011). Nordic prison practice and policy: Exceptional or not? Abingdon, UK: Routledge.

United Nations. (2018). Report of the secretary-general on conflict-related sexual violence. www.un.org/sexualviolenceinconflict/wp-content/uploads/report/s-2018-250/SGREPORT-2017-CRSV-SPREAD.pdf (accessed 15 May 2019).

Williamson, J., \& Serna, K. (2018). Reconsidering forced labels: Outcomes of sexual assault survivors versus victims (and those who choose neither). Violence against Women, 24(6), 668-683.

Witoszek, N., \& Midttun, A. (2018). Sustainable modernity and the architecture of the 'well-being society'. In N. Witoszek \& A. Midttun (Eds.), Sustainable modernity: The Nordic model and beyond (pp. 1-17). Abingdon, UK: Routledge.

World Economic Forum. (2018). The global gender gap report 2018. Geneva: World Economic Forum. 


\title{
2 Theorising sexual violence in intimate relations in Scandinavia
}

\author{
A literature review
}

\author{
Margunn Bjørnholt
}

\section{Introduction}

Theories and concepts are crucial to all academic thinking, and the literature review is a mandatory element in academic writing. The theory is usually presented in the introduction and ideally is used as a tool for analysis. But it is also not unusual to use theories as stepping stones only by presenting them in superficial and often caricatured ways as a means of rendering them obsolete, irrelevant and in need of replacement. As Clare Hemmings (2005, 2011) has argued, such has been the fate of second-wave feminist work by successive generations of feminist scholars. Theories and concepts are rarely studied in their own right, despite their importance to academic thinking. Studying theories and theorisations is crucial to understanding particular phenomena and fields of study as well as for academic self-reflection.

This chapter contributes to such academic self-reflection within the Nordic context by providing an analytic review of how selected Scandinavian ${ }^{1}$ scholars use gender theories and gender perspectives in their theorisations of sexual violence. The chapter, which is a conceptual piece, describes different strands of thinking about gender in relation to sexual violence and explores the relationship between these strands, with a particular focus on their relevance for theorising sexual violence within intimate relations.

Studies of violence and sexual violence are characterised by increasing theoretical diversity and methodological sophistication (Hester \& Donovan, 2009; Brown \& Walklate, 2011; Walby et al., 2015; Walby \& Towers, 2017). Nevertheless, in contrast to the growing literature on the history of concepts and theory in the social sciences (Somers, 1995; Doucet, 2015), theories of violence and sexual violence have seldom been the object of study. In the Scandinavian context, Anne-Lie Steen's study (2003) of discursive struggles in the field of violence studies in Sweden is, to my knowledge, the only Nordic study to date to have focussed exclusively on theories in this field.

In this chapter, I analyse contemporary theorisations of rape and sexual violence found in a small sample of recent publications by Scandinavian scholars. Searches were made for works published between 2012 and 2017 in the following Norwegian, Swedish, Danish and general Nordic databases: Idunn, sociological abstracts 
from ProQuest (for Norway, Sweden and Denmark), Norart, Den danske forskningsbase and Swepub. The final selection of publications also relied on my general reading and prior knowledge of relevant authors and publications. The main criteria of selection included having a gender perspective and being involved with theories of gender and violence. Because of my choice of recent contributions only, the chapter presents a snapshot rather than tracing the genealogy and development of theories over time and generations. Five publications (by Norwegian, Danish and Swedish authors), representing four different theoretical approaches, were eventually selected for the present analysis. The four approaches include the continuum approach, a structural-intersectional approach, a dialectic approach and an institutional, complex-systems approach. The anthropologist Bo Wagner Sørensen's (2013) study, which uses the continuum approach, is the only contribution presented in this chapter to specifically address sexual violence as part of domestic violence.

In their article on young girls' experiences of unwanted sexual touching, Kari Stefansen, Ingrid Smette and Dagmara Bossy (2014) also draw on the continuum approach to link the experiences of unwanted touching by acquaintances, friends and strangers to a normative theory of gender freedom; their approach is also potentially relevant for studying sexual violence in intimate relations.

Ulrika Andersson, Monika Edgren, Lena Karlsson and Gabriella Nilsson (2016), in their research project on genres of rape narratives in Sweden, study how stories of rape are told in three different contexts: in the legal system, in the media and in autobiographic material within social media. Using a structural-intersectional approach that invokes the early feminist conceptualisations of victimisation and agency, the authors draw on narrative theory and theories of genres to examine how rape is discursively produced in these three contexts.

Lena Gunnarsson (2018) suggests a dialectic approach inspired by critical realism, with a focus on the relations between experiences and discourses. She develops her argument by exploring the tensions between hegemonic discourses on rape and the more ambiguous experiences found in autobiographic stories by victims of different genders. The approaches represented by Andersson et al. (2016) and Gunnarsson (2018) are related, in that both in different ways combine cultural perspectives and different strands of radical feminist perspectives. I have still chosen to treat them separately, however, as they take as starting points two different strands of radical feminist thought.

In their book Stopping Rape, Sylvia Walby and co-authors (2015) develop a new holistic approach in which they argue that using a broad, institutional, complex-systems approach is necessary in theorising about and preventing rape. This approach most clearly differs from the other approaches in its focus on the macro level.

The first part of this chapter presents the four approaches. The analysis focusses on the authors' use of core concepts such as victimhood and agency as well as how the authors apply gender perspectives and integrate gender theories in their analyses. The different theoretical approaches are analysed in the latter part of the chapter, with the aim of identifying common themes and differences 


\section{0}

Margunn Bjørnholt

and discussing how using various approaches might be useful in making sense of sexual violence within intimate relations as a gendered phenomenon.

\section{The continuum approach}

\section{Sexual violence as part of intimate partner violence}

In his article on sexual violence within the narratives of victims of domestic violence in the Danish context, Sørensen (2013) found that the victims of domestic violence in his study did not necessarily distinguish between sexual violence and violence in general. Rather, for some 'it was just part of the whole' (69). Sørensen discusses this finding in relation to the general perception among researchers and practitioners of rape as being a particularly vicious form of violence; he argues that the analytic distinction between different forms of violence that researchers and practitioners typically make does not necessarily correspond to victims' experiences of intimate partner violence (IPV) as a total 'package' (2013).

Sørensen (2013) argues that the continuum approach is suitable for studying violence as a lived experience. The continuum approach, originally formulated by Liz Kelly (1987, 1988a, 1988b), starts with the idea that violence is present in all women's lives, while differences exist in the forms the violence takes and how different women define particular incidents. The concept is not a matter of a degree of seriousness; rather, Kelly argues that establishing hierarchies of forms of violence is problematic (1987, p. 49). Kelly uses the term 'sexual violence' for all forms of violence because of the difficulty in distinguishing between physical violence and sexual violence $(1987$, p. 59, footnote 1).

In his theoretical framing of the article, Sørensen (2013) places the continuum approach in a feminist understanding of violence as being rooted in power relations between men and women in which violence is linked to gendered identities and cultural perceptions of gender and gendered privileges. Sørensen argues that while several researchers have used the continuum approach, they have mainly used it on a descriptive level and have not fully utilised the approach's analytical potential (2013). Kelly (1988b) proposes two possible uses of the continuum. The first use is on a more abstract level, as a continuum of different means of male power and control over women; different incidents and topics are linked, thereby recognising their interconnectedness. The second use is the continuum's application on an empirical level by establishing links between everyday sexist male behaviours and the less frequent forms of abuse defined as crimes.

In defining violence, Sørensen (2013) draws on David Riches's (1986) tripartite definition of interpersonal violence as always involving a victim, a perpetrator and one or more witnesses. In Sørensen's conceptualisation, witnesses can be understood as all actors who may have an effect on the interpretation of the violent act (2013). The general social climate towards violence and the recognition over the last fifty years of violence as a social problem - both a result of the international and national women's movements - have changed the relationship 
between victim and perpetrator and have reduced perpetrators' power of interpretation. Inspired also by Sally Engle Merry's work (2003, 2009), Sørensen (2013) suggests that victims of violence are legitimate victims, in the sense of legal subjects who have had their human rights violated. This understanding avoids the futile discussions of the problems with attributing or claiming a victim identity, which is associated with stigmatisation, passivity and lack of agency. In contrast, Sørensen (2013) argues, no antagonism exists between the position of a violated legal subject and agency, as illustrated in the concept of 'survivor' used by victims of rape and sexual abuse. Rather, recognition of the experience of being a victim is the prerequisite of being a survivor. Sørensen's (2013) main contribution is to reintegrate sexual violence into the understanding of IPV by theorising from victims' experiences and drawing on the concept of a continuum of violence that links other acts of IPV and sexual violence.

\section{Unwanted touching on a continuum of sexual violence}

In their article on young girls' experiences of unwanted sexual touching from acquaintances and strangers, Stefansen et al. (2014) also use the continuum approach; they see mild sexual violations as (1) being different from severe sexual violations, (2) connected at an experiential level and (3) linked to an underlying gender-power dimension. They view the approach as useful in elucidating differences within the same form of violation. The authors refer to the two different lexical definitions of a 'continuum' that Kelly (1988a, p. 76) refers to: what is common to different incidents versus a series of incidents that may be difficult to separate. Stefansen et al. (2014) use the latter definition as an opportunity to identify different forms of unwanted touching and to create a typology of such sexual violations.

Stefansen et al. (2014) also draw on Carol Smart's work (1995) on the 'disciplining' effects on all women of accumulated minor sexual offences and the importance of studying minor sexual offences as constitutive of gender-power relations, in that they confirm the lack of bodily protection and women's lack of the right to be left alone, in contrast to men. Both unwanted sexual touching and rape are 'demonstrations of the same problem of women being constituted as sexualized' bodies (Smart, 1995, p. 223, cited in Stefansen et al., 2014, p. 6). Stefansen et al. (2014) argue that minor assaults - such as in Smart's (1995) example of a woman who had her breast squeezed in public by a stranger - not only affect the particular woman but also serve as a reminder to all women of their vulnerability, hence contributing to a diffuse, latent fear (Sheffield, 1989) that then blurs the boundary between normal male aggression and more rare forms that 'shade into one another' (Kelly, 1988a, p. 75, cited in Stefansen et al., 2014, p. 6). Still drawing on Smart (1995), however, the authors argue that it is also important to recognise the potential ambiguity of such experiences, since the same incident may simultaneously make a woman feel attractive and incite fear within her.

Finally, Stefansen et al. (2014) draw on the Norwegian legal scholar Tove Stang Dahl's (1994) definition of sexual violence as a violation of gender 


\section{Margunn Bjørnholt}

freedom. Dahl (1994) argued that the strong focus on violence and the use of physical force in rape cases may overshadow other aspects of force preceding the rape act, such as confinement. Using rape in the context of hitchhiking as an example, Dahl argued that the crime in this particular case started when the driver took the victim to a different destination than agreed upon, did not let her out when she asked and locked the doors to prevent her from escaping. Stefansen et al., too, focus on situations in which the unwanted touching is related to other violations of the freedom of movement and elements of force, such as being locked up, restrained or violated while in a particularly vulnerable state (2014). Based on descriptions of unwanted touching, Stefansen et al. distinguish between three different forms of unwanted touching: sexual invasion, explorative touching and aggressive touching (2014).

Like Sørensen (2013), Stefansen et al. (2014) theorise from victims' experiences by drawing on the concept of a continuum of sexual violence. They both take as their starting point the misfit between victims' experiences and the available concepts. While Sørensen (2013) focusses on reintegrating sexual violence with other forms of severe IPV and the level of experience, Stefansen et al. (2014) focus on the distinctions between different forms of 'mild' sexual violations outside of couple relationships. By developing a typology of different forms of unwanted touching, Stefansen et al. (2014) contribute to recognising and naming such experiences. Introducing Dahl's (1994) concept of gender freedom as a normative standard against which to measure these experiences, the new typology becomes an important tool for recognising, naming and resisting unwanted touching, thereby clarifying and reducing the ambiguity of the victim position.

\section{The structural intersectional approach}

Andersson et al. (2016), a multidisciplinary research group, based on law, gender studies, ethnology and history, present in their paper a research project on Swedish discourses on rape since 1990. The project focusses on the production of hegemony and truth by an examination of three kinds of sources and the relations between them: (1) legal texts on rape (with a focus on discussions of force and consent) and the intersections of power and subordination in such texts; (2) rape narratives in the media and the consequences for political mobilisation of the separation of rape narratives into different types/genres, depending on the relation to the perpetrator or the context; and (3) biographical stories in the response to social media campaigns, with a focus on the role of personal experience in political mobilisation.

Andersson et al. (2016) draw on feminist critiques of 'linking rape to sexuality, which in turn is constructed as the basis for the inner (core) of human beings' (p. 88). Following Carine Mardorossian's work (2014), Andersson et al. (2016) draw on Susan Brownmiller's (1975) and Michel Foucault's work on the sexualisation of bodies in Western culture $(1979,1990,1992)$. Brownmiller problematised the concept of consent from a radical feminist perspective (1975, p. 384, cited in Andersson et al., 2016, p. 87), arguing that the idea of consent was based on a liberal view of women's bodies as autonomous and rape as a violation of 
individual integrity. This view is at odds with the radical feminist theoretical position that rape is a question of gender and power at the societal level.

Second-wave feminists framed rape as violence against women and introduced the concept of power at the system level (i.e. through patriarchy) into the public debate on rape. They also widened the understanding of what rape is and who can be raped. According to Brownmiller (1975), rape is a political act, the purpose of which is to frighten and degrade women as a group. Andersson et al. (2016) argue that the benefit of this perspective, which separated rape from sexuality, was to make the question of consent irrelevant; thus, issues of shame and guilt, and the related victim role, are also irrelevant. If we think of rape as being related to sex, then the victim is made complicit via the notion of consent, which then leads to personal shame and guilt. In contrast, Brownmiller (1975) argued that women were victims only of patriarchal power, thus offering a victim position linked to agency and resistance.

Andersson et al. (2016) also refer to the work of Ann Cahill (2001), who argues from a phenomenological feminist perspective that draws on feminist theorisations of the body as the basis of gender difference and the inscription of power. Following Mardorossian (2002, 2014), Andersson et al. (2016) also refer to Foucault's $(1979,1990,1992)$ work on the perpetual reproduction of the body as sexual (specifically heterosexual) and the reduction of human existence to the use of the body's reproductive organs. Foucault (1977) argued that resistance should be directed against the discursive power that describes sexuality as the core of being human; this discourse underpins the perception that rape is the worst that can happen to a woman, since it robs her of her worth as a human being.

With Mardorossian (2002, 2014), Andersson et al. (2016) want to return to the second-wave feminist view on rape victims as active subjects rather than what they see as the prevailing view: as objects to be acted on by victimologist help agencies. Emphasising structural-intersectional positions and the decoupling of rape from erotic sexuality, Andersson et al. (2016) contribute to the ongoing theoretical endeavours to synthesise radical feminist thinking, feminist theories of the body and poststructuralist thinking. Focussing on power relations and political mobilisation, they invoke the legacy of radical feminist theorisations in which sexual violence was viewed as an expression of gendered power relations.

\section{The dialectic critical-realist approach}

Gunnarsson (2018) explores the tensions between dominant popular understandings that discursively juxtapose sex and rape and the more continuum-like and ambiguous realm of experience in women's and non-binary people's narratives of sexual encounters in the 'grey zone' between sex and abuse. She then analyses narratives of men who do not want sex and male victims of sexual abuse, as a contrast to discourses that presume men always want sex and that ignore men's vulnerability and victimisation. Related to the lack of fit between discourse and experience, she argues that experiences and gendered subjectivities are shaped by discourses. 


\section{Margunn Bjørnholt}

Gunnarsson (2018) aims to reconcile discursive constructions of sexual violence and experiences of sexual violence by suggesting a dialectic approach inspired by critical realism (Bhaskar, 2008). Scholars of feminist theory have hotly debated the relationship between experience and discourse (Scott, 1992; Alcoff, 2000). And, in research on sexual violence and victimisation, poststructuralist scholars have argued that the concepts and discourses typically used to name sexual violence may perpetuate the problem they describe by locking women in a powerless position of rapability (Marcus, 2002). Others see this argument as a trivialisation of women's experiences and have argued that rape is not a discursive problem (Hawkesworth, 1989; Mardorossian, 2002). Gunnarsson (2018) carves a path through this polarisation between the realist and discursive approaches by exploring the dialectic between dominant discourses on sex and people's reported experiences in the grey zone between sex and sexual violence. Referring to the work of Linda Alcoff $(2000,2014)$ ), among others, Gunnarsson argues that experiences and discourses mutually influence each other (2018).

In her analysis of this grey area between sex and rape, Gunnarsson (2018), too, draws on a continuum perspective. She refers to Gavey $(1999,2005)$, who argues that it is difficult to draw a line between 'just sex' and sexual violence, and to scholars who have pointed to the similarities and overlap in the scripting of heterosexual romance/sexual pursuit and rape (Gilbert \& Webster, 1982, cited in Kelly, 1988a, p. 74; Gunnarsson, 2018, p. 7). This notion was most radically formulated by Catharine MacKinnon (1989), who questioned how to tell the difference between normal sex and violence in a culture and a sexual and gendered reality that eroticises male power and female submission. In a less reductionist form of this insight, Gunnarsson (2018) also refers to the observation that normative heterosexuality is infused with violent dynamics and can be thought of as a continuum in which typical male behaviours and 'aberrant' male behaviours shade into one another, as formulated in Kelly's continuum concept (1988a, p. 75). MacKinnon's (1989) and Kelly's (1987, 1988a, 1988b) ideas have been taken up and reworked in later explorations of the ambiguous grey area between the categories of sex and sexual violence (Gavey, 1999, 2005; cf. Powell, 2008; Cunniff Gilson, 2016).

With Gavey, Gunnarsson also argues that scholars who endorse a 'dimensional' view of sexual violence generally operate on two levels, which they normally do not explicitly distinguish: (1) sex and violence are often difficult to distinguish within the experience, and (2) the discursive scripting of heterosexual sex and sexual violence overlaps (Gavey, 1999, p. 60, cited in Gunnarsson, 2018, p. 7).

This tension between discourse and experience was what fuelled the \#prataomdet ('talkaboutit') campaign in Sweden. An important framing of the campaign was the need for a new language to map nuances in people's experiences of sex and violence. In her analysis of women's narratives from the campaign, Gunnarsson (2018) found that the grey area was in the difficulty in discerning the boundary between sex and violence. In analysing these narratives, Gunnarsson (2018) draws on feminist scholarship on rape and 'rape scripts', referring to Kathryn Ryan's work (2011): if rape is constructed as 
something monstrous and removed from everyday life, while in reality it shades into common sexual affairs, then this discourse makes it difficult to identify, both at an individual and societal level.

Gunnarsson (2018) finds that the rape script makes it difficult both to name experiences of sexual violence and to stop acts of sexual violence. In one \#prataomdet story, that lends her article its title, a woman woke up in pain, realising her boyfriend had done things to her that she had not consented to, but she had not intervened or tried to stop him. The woman asked in retrospect, 'What was I supposed to say? "Excuse me, but are you raping me now?" The rape script also makes it difficult to confront the perpetrator. In another \#prataomdet story, the victim ended up comforting the perpetrator: after confronting her boyfriend that he had raped her in her sleep, he started to cry and made her take it back, as he could not bear being a rapist, thus illustrating the risks involved in rendering one's partner a 'psychopathic monster'.

In analysing the male-authored narratives in the \#prataomdet campaign, Gunnarsson (2018) refers to the shared foundation of both sex and rape in the discourse on the 'male sex drive'. A man who does not want sex not only violates the social expectation of men always wanting sex but also violates his masculine identity that was formed by this discourse. Exploring the gap between his experience of not wanting sex while at the same time wanting or claiming to want it, Gunnarsson (2018) explores how discourses may simultaneously shape expectations and subjectivities and produce tensions at an individual level.

Like Andersson et al. (2016), Gunnarsson, too, can be seen as synthesising different strands and different generations of feminist theorisations of rape by exploring the gaps in accounts of grey-zone experiences between discourses and experiences (2018). In involving theorisations of grey zones that draw on feminist theorisations in which rape is viewed as being related to 'just sex' in the MacKinnon (1989) tradition, Gunnarsson (2018) explores the ambiguities of the victim position. Her contribution illustrates the need to empirically study and to critically discuss the discursive framings of experience as well as the role of discourses in shaping gendered subjectivities and interactions.

\section{The institutional approach}

In Stopping Rape (2015), Walby and co-authors - among them Sofia Strid, who is a Swedish scholar, which is why this general work on rape is included in the present volume on rape in the Nordic countries - argue that the theorisation and prevention of rape requires a broad, institutional approach and a theoretical model that will account for the complex, causal pathways to rape. Taking a holistic, complex-systems approach, the authors argue that the production and prevention of rape can be understood to occur at three levels of analysis: (1) societal-level systems (gender regimes and overall violence); (2) social institutions (planning/political, health, conflict/military, civil society, economics, and law and criminal justice); and (3) the level of individual victims and rapists. Looking not only at individuals but also at the effects of other institutions 
relevant to rape, the authors emphasise how both the understanding of causal pathways to rape and rape prevention may be affected by changes at all these levels; they also discuss how changes at one level may affect the other levels via feedback systems.

Support services for victims are one example: better-supported victims (i.e. the individual level) may be empowered to endure the criminal justice process, thus leading to more convictions (i.e. the institutional level). Further, empowered victims will be capable of speaking out and educating the public and politicians on the reality of rape, which will challenge rape myths and contribute to the prevention of rape. In this conceptualisation, the mutual relations between experience and discourse, theorised in several of the previous contributions, are thought of as part of possible feedback systems in a complex system. Further, the general level of gender inequality/equality policies and the social systems of violence in particular societies shape the institutions that are relevant to rape.

The authors develop their model by detailing six institutional fields: (1) strategy, planning and coordination; (2) victim and healthcare systems; (3) law and criminal justice systems; (4) conflict zones (specifically rape in such zones); (5) culture, media and education; and (6) economics. They present their research findings as well as selected successful interventions within each field. This broad scope is enabled by the book's co-authorship by a large, interdisciplinary and international team of scholars who provide a broad overview, combined with deep insights into the particular issues they cover. For instance, the authors argue that economic gender inequality is related to rape; indeed, previous studies have found that unemployed women are more often exposed to rape (Walby \& Allen, 2004; Kelly, Horvarth, Uzelac, \& Lovett, 2007). Riger, Staggs, and Schewe (2004) found an inverse relationship between work stability and rape, which might be an important finding in the context of the increasing precariousness of the labour market. Research by one of the Stopping Rape co-authors, Bina Agarwal, shows how in India, purported employment may take the form of unpaid work in the family business, which often provides neither a decent income nor autonomy (Agarwal \& Panda, 2007). Rather than such positions providing employment as such, Agarwal and Panda found that having access to property and other tangible economic means had a protective effect (2007). This scenario illustrates that strategies of women's economic empowerment as part of preventing rape must be well researched and specific.

The holistic-systemic approach, which emphasises the interplay between different systems at different levels, calls for research at different levels as well as at an overall systems level. Walby et al. (2015) argue that understanding the causal pathways to rape requires theoretically and empirically determining the interactions between different institutional fields and the working of feedback systems. Some of the other approaches' theoretical concerns are also present in Walby et al.'s (2015) contribution, such as the importance of discourses and that victims speak up. In their approach, however, the focus is not predominantly on the internal relationship between discourse and experience but on how these factors interact with other elements in the social system. Further, the use 
of this approach also implies an ambition and a need to theorise and understand the operation of combined systems at a macro level. By introducing the concept of violence regimes and linking them to gendered welfare-state regimes, Strid (the Swedish co-author mentioned earlier) has proceeded in this direction in a new study on 'Gendered violence regimes' (Delaunay \& Strid, 2018).

\section{Theoretical diversity and innovation}

This review, although far from exhaustive, has revealed some of the theoretical diversity and innovation found in making sense of sexual violence among Scandinavian scholars and mirrors the growth in-depth and sophistication notable in theoretical approaches in the field internationally (Brown \& Walklate, 2011). The contributions also demonstrate the continued relevance and theoretical potential of renewed and continued involvement with different strands of second-wave feminist theorisations of sexual violence.

The four approaches presented in this chapter explicitly draw on or involve earlier feminist work while also reflecting and reproducing some of the controversies between different strands of early feminist theorisations on core issues such as the relation between sex and violence. Andersson et al. (2016), for example, drawing on the work of Brownmiller (1975) and Foucault (1977, 1979, 1990, 1992), position themselves against linking sex and rape, while Gunnarsson (2018) explores the grey zone between sex and rape and takes as her starting point that sex and rape can be understood as a continuum - a position most radically formulated by MacKinnon (1989) and reworked and nuanced by others such as Gavey (2005). The continuum concept (Kelly, 1987, 1988a, 1988b) features prominently in three of the contributions. The widespread and different ways in which the authors use the continuum concept illustrate the idea's continued relevance and analytical usefulness, as well as how the concept can be employed in various - and not necessarily compatible - ways.

\section{Different uses of the continuum concept}

Sørensen (2013) draws on the continuum concept to explore the relations between sexual violence and other forms of violence (such as domestic violence) from intimate partners. He argues that sexual violence may well be part of a more general picture of violence and that victims of domestic violence (which often includes sexual violence) do not necessarily distinguish between different forms of violence at the experiential level. In their use of the concept, Stefansen et al. (2014) hope to coin new concepts for sexual experiences in the grey zone between sex and violence. They also draw on the concept of a continuum at an experiential level by linking acts of sexual violence to other acts of force and the violation of freedom of movement; in addition, they refer to the wider cultural level and link minor sexual offences by acquaintances to sexualised micro-aggression in the public sphere, both of which limit girls' and women's gender freedom. 


\section{Margunn Bjørnholt}

Gunnarsson (2018), who also explores grey-zone experiences, focusses on the continuum between sex and rape. Walby et al. develop a wider institutional approach that transcends the continuum approach, which they refer to only briefly as a way of capturing 'the way in which small events are connected to create a context that is more threatening than the sum of its parts' $(2015, \mathrm{p} .12)$.

\section{Conceptualisations of the victim}

One common denominator among these studies is a general concern for working out concepts of victimisation that will leave room for agency, hence challenging notions of victimisation that imply passivity. Andersson et al. (2016) explicitly draw on second-wave feminist theorisations, in particular Brownmiller's (1975), to revitalise the link between victimhood and agency. So does Sørensen (2013), who draws on feminist conceptualisations (Merry, 2003) in which the victim is viewed as a violated legal subject - a position from which to act and a prerequisite for agency (Kelly, Burton, \& Regan, 1996), in contrast to being a 'broken subject' - as well as drawing on Riches's (1986) tripartite model of victimhood. In this model, which involves the victim, the perpetrator, and one or more witnesses, the broader culture and general attitudes to rape are included in the definition of the witness and the role witnesses play in the model.

Walby et al. (2015) explicitly limit their investigation to rape; in their contribution, victims of rape are victims of criminal acts. In their discussion of feedback systems that might influence understandings and social and legal responses to rape, Walby et al. also use as an example the possible effects of changes in the legal and social responses to rape for victims who speak up.

This strong emphasis on the victim's agency may be seen as part of an effort to repoliticise the field and to mobilise rape victims' voices in the political struggle against rape. This focus on agency and voice may be problematic, however, in that it may produce new normative expectations as to how victims should act. For instance, the imperative to be strong and agentic, to speak out and to report, may be felt as a moral norm but may not be in an individual victim's interest. In a recent master thesis, Marie Louise Hansen (2018) highlights how rape victims negotiate these norms in order to avoid the personal and social costs of reporting.

Gunnarsson (2018) discusses the ambiguity of the victim position and how hegemonic discourses may make it difficult to identify sexual violence or to harbour non-typical victims' experiences and vulnerabilities. Sørensen (2013) and Stefansen et al. (2014) also highlight the lack of fit between the available concepts and the experiences of sexual violence.

\section{Gender theory}

All the contributions analysed so far have explicitly drawn on and engaged with theories of gender and sexual violence, and some have also drawn on more general gender theories. Sørensen (2013) and Stefansen et al. (2014), who use the continuum approach, analyse empirical material and contribute to new 
conceptualisations and theorisations of sexual abuse while also discussing such abuse's link to gender hierarchies (Sørensen, 2013) and gender cultures that limit women's and girls' gender freedom (Stefansen et al., 2014). Sørensen (2013) mainly refers to theories of gender violence and argues for including sexual violence in general studies of domestic violence/IPV.

Andersson et al. (2016) also employ more general feminist and poststructural theories, including feminist theories of the body, and focus on gendered power relations and political mobilisation related to gender and violence. Gunnarsson (2018) combines second-wave feminist theorisations of sexual violence and poststructural approaches with critical realism, with the aim of theorising the gap between discourses and experiences. Walby et al. (2015) cite gender theories and policies at the international and national levels to develop a holistic model of the social production and prevention of rape.

\section{Concluding remarks}

The aim of this review has been to map various theorisations of sexual violence that are potentially relevant for understanding sexual violence in intimate relations as a gendered phenomenon. The contributions presented in this chapter differ both in terms of which acts of sexual violence they address and in which kinds of relationships and perpetrators they include and exclude. Only one contribution (Sørensen, 2013) addresses sexual violence from partners alone (as part of domestic violence); the other contributions address sexual violence per se and in different relations.

A comprehensive approach to sexual violence as a gendered phenomenon needs to draw on and synthesise a variety of perspectives in order to explain the co-production of gender and sexual violence that results in this gendered pattern of victimisation and perpetration. Such an approach also needs to explain how this gendered phenomenon is linked to broader processes in contemporary societies that produce and facilitate sexual violence - in ways that will not exclude the experiences of victims and perpetrators who do not fit with the general gendered pattern of sexual violence. This goal demands a multidimensional and multilevel approach - in line with what Walby et al. (2015) propose - that will take into consideration different institutional levels, from particular institutions to national regimes, of gender and violence. The individual and interactional levels are still important, however, and we need to be able to recognise and name grey-zone experiences. With their typology of unwanted touching, Stefansen et al. (2014) have provided tools for recognising, naming, and potentially resisting such events. In line with Gunnarsson's (2018) dialectic critical-realist approach, I would add the need to further explore gendered subjectivities and discourses (and the tensions between them) as well as ontological sex differences. Finally, and in line with Sørensen (2013), we must explore how sexual violence from intimate partners is part of the broader picture of IPV and discuss the gains and potential problems of singling out sexual violence as a particular field of study, separate from IPV studies. 


\section{Margunn Bjørnholt}

The recent rapprochement of poststructuralist and radical feminist theories (which is also visible in the Scandinavian context) may be seen as part of an ongoing process of theorising from the experiences of new generations who are trying to understand sexual violence in the context of the uneven process of changing gender structures, gender discourses, gender relations, and gendered subjectivities. The continued relevance and engagement with radical feminist theorising in recent theorisations of sexual violence may be thought of as arising from the need to theorise gender-power relations. We must study the experiential continuum of sexual violence in different contexts and relationships in order to understand, recognise and name such experiences and to construct categories that will represent victims' lived experiences. Theorisations of rape, sexual harassment and grey zones in other-than-intimate relationships may also be helpful in making sense of sexual violence in intimate relations (see Bjørnholt \& Helseth, 2019). Nevertheless, we must further explore sexual violence in intimate relationships, specifically within the relational dynamics of couple relationships.

\section{Note}

1 The choice to select only publications from the Scandinavian countries is a pragmatic one. As a Norwegian, the author also reads languages Danish and Swedish, but not the languages of the other Nordic countries.

\section{References}

Agarwal, B., \& Panda, P. (2007). Toward freedom from domestic violence: The neglected obvious. Journal of Human Development, 8(3), 359-388.

Alcoff, L. M. (2000). Phenomenology, post-structuralism, and feminist theory on the concept of experience. In L. Fisher \& L. Embree (eds.), Feminist phenomenology (pp. 39-56). Dordrecht, the Netherlands: Springer.

Alcoff, L. M. (2014). Sexual violations and the question of experience. New Literary History, 45(3), 445-462.

Andersson, U., Edgren, M., Karlsson, L., \& Nilsson, G. (2016). Våldtäkt i Sverige 1990-2013: Ett historiskt och intersektionellt perspektiv på berättelser om våldtäkt inom olika genrer [Rape in Sweden 1990-2013: A historical and intersectional perspective on narratives of rape in different genres]. Gränsløs: Tidskrift för studier av Öresundsregionens historia, kultur och samhällsliv [Limitless: Journal of Studies of the History, Culture and Religion of the Öresund Region], 6, 82-92.

Bhaskar, R. (2008). Dialectic: The pulse of freedom. London: Routledge.

Bjørnholt, M., \& Helseth, H. (2019). 'Jeg ville jo si nei' - Seksuell vold i parforhold ['I would have said no' - Sexual violence in intimate relations]. In K. Skjørten, E. Bakketeig, M. Bjørnholt, \& S. Mossige (eds.), Vold i noere relasjoner [Violence in intimate relations]. Working title. Oslo: Universitetsforlaget, 86-103.

Brown, J. M., \& Walklate, S. L. (eds.). (2011). Handbook on sexual violence. London \& New York: Routledge.

Brownmiller, S. (1975). Against our will: Rape, women, and men. New York: Simon \& Schuster.

Cahill, A. J. (2001). Rethinking rape. Ithaca, NY: Cornell University Press. 
Cunniff Gilson, E. (2016). Vulnerability and victimization: Rethinking key concepts in feminist discourses on sexual violence. Signs: Journal of Women in Culture and Society, 42(1), 71-98.

Dahl, T. S. (1994). Pene piker haiker ikke: Artikler om kvinnerett, strafferett og velferdsstat [Nice girls don't hitchhike: Articles on women's law, criminal law, and the welfare state]. Oslo: Universitetsforlaget, and Copenhagen: Akademisk Forlag.

Delaunay, M., \& Strid, S. (2018). Gendered violence regimes: Context, policy and practice in intimate partner violence in France and Sweden. Presentation at the IXI ISA World Congress of Sociology, July 15-21, Toronto.

Doucet, A. (2015). Parental responsibilities: Dilemmas of measurement and gender equality. Journal of Marriage and Family, 77(1), 224-242. doi:10.1111/jomf.12148

Foucault, M. (1977). La folie encerclée. Paris: Change Collective.

Foucault, M. (1979 [1976]). The history of sexuality volume 1: An introduction. London: Allen Lane.

Foucault, M. (1990 [1984]). The history of sexuality volume 3: The care of the self. London: Penguin Books.

Foucault, M. (1992 [1984]). The history of sexuality volume 2: The use of pleasure. London: Penguin Books.

Gavey, N. (1999). 'I wasn't raped, but ...': Revisiting definitional problems in sexual victimization. In S. Lamb (ed.), New versions of victims: Feminists struggle with the concept (pp. 57-81). New York and London: New York University Press.

Gavey, N. (2005). Just sex: The cultural scaffolding of rape. New York: Routledge.

Gilbert, L., \& Webster, P. (1982). Bound by love: The sweet trap of daughterhood. Boston: Beacon Press.

Gunnarsson, L. (2018). 'Excuse me, but are you raping me now?' Discourse and experience in (the grey areas of) sexual violence. NORA: Nordic Journal of Feminist and Gender Research, 26(1), 4-18.

Hansen, M. L. J. (2018). Vilje og motvilje: Fortellinger bak ikke-anmeldte voldtekter [Will and resistance: Stories behind non-reported rapes]. Master thesis. University of Oslo.

Hawkesworth, M. E. (1989). Knowers, knowing, known: Feminist theory and claims of truth. Signs: Journal of Women in Culture and Society, 14(3), 533-557.

Hemmings, C. (2005). Telling feminist stories. Feminist Theory, 6(2), 115-139.

Hemmings, C. (2011). Why stories matter: The political grammar of feminist theory. Durham, NC: Duke University Press.

Hester, M., \& Donovan, C. (2009). Researching domestic violence in same-sex relationships: A feminist epistemological approach to survey development. Journal of Lesbian Studies, 13(2), 161-173.

Kelly, L. (1987). The continuum of sexual violence. In J. Hanmer \& M. Maynard (eds.), Women, violence and social control (pp. 46-60). London: Palgrave Macmillan.

Kelly, L. (1988a). Surviving sexual violence. Cambridge, UK: Polity Press.

Kelly, L. (1988b). How women define their experiences of violence. In K. Yllo \& M. Bograd (eds.), Feminist perspectives on wife abuse (pp. 114-132). Thousand Oaks, CA: Sage.

Kelly, L., Burton, S., \& Regan, L. (1996). Beyond victim or survivor: Sexual violence, identity and feminist theory and practice. In L. Adkins \& V. Merchant (eds.), Sexualizing the social (pp. 77-101). London: Palgrave Macmillan.

Kelly, L., Horvarth, M., Uzelac, G., \& Lovett, J. (2007). Rape in the 21st century: Old behaviours, new contexts and emerging patterns. Swindon, UK: Final Report to the Economic and Social Research Council (ESRC). 


\section{Margunn Bjørnholt}

MacKinnon, C. A. (1989). Toward a feminist theory of the state. Cambridge, MA: Harvard University Press.

Marcus, S. (2002). Fighting bodies, fighting words: A theory and politics of rape prevention. In J. Butler \& J. W. Scott (eds.), Feminists theorise the political (pp. 403-421). New York and Abingdon, UK: Routledge.

Mardorossian, C. M. (2002). Toward a new feminist theory of rape. Signs: Journal of Women in Culture and Society, 27(3), 743-775.

Mardorossian, C. M. (2014). Framing the rape victim: Gender and agency reconsidered. New Brunswick, NJ and London: Rutgers University Press.

Merry, S. E. (2003). Rights talk and the experience of law: Implementing women's human rights to protection from violence. Human Rights Quarterly, 25(2), 343-381.

Merry, S. E. (2009). Human rights and gender violence: Translating international law into local justice. Chicago and London: University of Chicago Press.

Powell, A. (2008). Amor fati? Gender habitus and young people's negotiation of (hetero) sexual consent. Journal of Sociology, 44(2), 167-184.

Riches, D. (1986). The phenomenon of violence. In D. Riches (ed.), The anthropology of violence. Oxford, UK: Basil Blackwell, 1-28.

Riger, S., Staggs, S. L., \& Schewe, P. (2004). Intimate partner violence as an obstacle to employment among mothers affected by welfare reform. Journal of Social Issues, 60(4), 801-818.

Ryan, K. M. (2011). The relationship between rape myths and sexual scripts: The social construction of rape. Sex Roles, 65(11-12), 774-782.

Scott, J. W. (1992). Experience. In J. Butler \& J. W. Scott (eds.), Feminists theorise the political (pp. 40-58). New York and Abingdon, UK: Routledge.

Sheffield, C. J. (1989). The invisible intruder: Women's experiences of obscene phone calls. Gender \& Society, 3(4), 483-488.

Smart, C. (1995). Law, crime and sexuality: Essays in feminism. London, Thousand Oaks, CA, and New Delhi: Sage.

Somers, M. (1995). What's political or cultural about political culture and the public sphere? Toward an historical sociology of concept formation. Sociological Theory, 13 (2), 113-144. doi:10.2307/202157

Sørensen, B. W. (2013). Voldens kontinuum og kvinders voldserfaringer [The continuum of violence and women's experiences of violence]. Sosiologi i dag [Sociology Today], 43(4), 69-93.

Steen, A.-L. (2003). Mäns våld mot kvinnor - Ett diskursivt slagfält: Reflektioner kring kunskapsläget [Men's violence against women - A discursive battlefield: Reflections on knowledge status]. Göteborg, Sweden: Göteborgs universitet sociologiska institutionen.

Stefansen, K., Smette, I., \& Bossy, D. (2014). Angrep mot kjønnsfriheten: Unge jenters erfaringer med uønsket beføling [Attack on gender liberty: Young girls' experiences with unwanted touching]. Tidsskrift for kjønnsforskning [Journal of Gender Studies], 38(1), 3-19.

Walby, S., \& Allen, J. (2004). Domestic violence, sexual assault and stalking: Findings from the British Crime Survey. London: Home Office.

Walby, S., Olive, P., Towers, J., Francis, B., Strid, S., Krizsan, A., ... Armstrong, J. (2015). Stopping rape: Towards a comprehensive policy. Bristol: Policy Press.

Walby, S., \& Towers, J. (2017). Measuring violence to end violence: Mainstreaming gender. Journal of Gender-Based Violence, 1(1), 11-31. 


\title{
3 Cultivating ethical negotiations or fetishising consent in BDSM?
}

\author{
Monika Grønli Rosten
}

\section{Introduction}

By the end of 2015, I had begun to recruit participants for a research project on exposure to intimate partner violence (IPV) and help-seeking as part of the domestic-violence research programme (2014-2019) at the Norwegian Centre for Violence and Traumatic Stress Studies. One day I received an email from Tina (26):

I think I might be in the target group for your study, but I'm struggling to explain why. A few years ago, I was in a relationship with a woman, and I've realised since then that I've been manipulated, forced into situations where I was uncomfortable, and it feels like I've lost myself somehow along the way. She performed a kind of 'voluntary' violence against me, as we both consented to it (BDSM). Since the relationship ended, I've struggled with severe anxiety and depression, and I haven't been able to seek help.

Tina had engaged in an intimate relationship involving the practice of BDSM (bondage/discipline, dominance/submission, sadism/masochism). As an acronym for bondage/discipline, dominance/submission and sadism/masochism, the term 'BDSM' is used to distinguish a wide range of erotic practices from mainstream normative sexuality. BDSM community members often juxtapose their own various alternative practices with the duller 'vanilla sex' practised by outsiders (Newmahr, 2011).

When the relationship ended, Tina found herself hurt, confused and frightened. In her own words, she had been exposed to violence 'kind of voluntarily' (i.e. BDSM), which made her wonder whether she was in the target group for a study on IPV. Had she been subjected to physical or sexual violence at all? Had she instead experienced psychological abuse from a manipulative girlfriend? Or could what happened between them simply be labelled 'bad BDSM', in the popular sense of 'bad sex'? She asked herself these questions as she deliberated whether she was entitled to professional help for a 'self-inflicted' trauma.

This chapter, using the complex relationship between sexuality and power exchanges in BDSM as a backdrop, will address what has been referred to as 
the 'grey area' (Gavey, 2005) and the 'murky interface of consent and coercion' (Gunnarsson, 2018, p. 3). The World Health Organization (WHO, 2002) defines violence as 'the intentional use of physical force or power, threatened or actual, against oneself, another person, or against a group or community, that either results in or has a high likelihood of resulting in injury, death, psychological harm, maldevelopment or deprivation'. In this definition, violence is understood as an actual fact: both an intention and a set of real-life consequences. In the following analysis, we will instead understand violence as a social construct that emerges from struggles of legitimacy in a particular cultural and historical context.

In this chapter, I refer to illegitimate BDSM as 'sexual violence', as BDSM in my understanding is strongly related but at the same time encompasses sexuality. What differentiates BDSM from sexual violence, as a socially constructed category, is first the prerequisite of consent (or not) to participate, and second the fact that the BDSM practice itself is seen as a game of make-believe, as opposed to real violence (McClintock, 1993; Newmahr, 2010). But how do participants in BDSM draw this line in actual practice, and what role does the idea of consent play?

Throughout this chapter, we will explore the social construction of sexual violence in BDSM from different angles, all revolving around the question of consent. I will problematise the idea of consent as a way of properly distinguishing BDSM from sexual violence by drawing on interviews with Tina and other BDSM practitioners. Towards the end of the chapter, I will reflect on what we can learn about IPV and consent from this particular context.

\section{The consent problem}

The concept of consent tends to mean different things to different people, both in academic discourse and in everyday life. In relation to sexuality, 'consent' can be defined as the 'the freely given verbal or non-verbal communication of a feeling of willingness' (Hickman \& Muehlenhard, 1999, p. 259). In sexual-violence prevention in the Western world, according to Beres (2014, p. 373), the message "no means no' has gradually been replaced by 'yes means yes'. The same discursive shift is visible in online BDSM communities and the blogosphere (Barker, 2013). Encouraging explicit rather than implicit communication of consent is often seen as a way of avoiding misunderstandings.

Insisting on the importance of affirmative consent is also useful in fighting sexual violence. Rape is wrong, Cahill states (2001, p. 170), precisely because 'it undermines the integrity of the personhood of the victim by denying their right of consent over that property that is most personally, most intensely held: the body'. In Cahill's discussion of rape and the problem of consent (2001), the author further explains how rape in the traditional Western understanding was defined as a crime against primarily male property. In this logic, women did not possess their sexuality, so the question of consent was irrelevant. In liberal theory, in contrast, rape is a violation of personal autonomy, where lack of consent is the very definition of the crime. An obvious challenge in this approach is that the communication of consent is not necessarily the same as actually 
wanting to participate (Beres, 2014; West, 2008). In the classic 'Women and Consent', Pateman defines the consent problem as an ideal in liberal societies: 'consent is central to liberal democracy, because it is essential to maintain individual freedom and equality; but it is a problem for liberal democracy, because individual freedom and equality is also a precondition for the practice of consent' (1980, p. 162). In other words, consent is never given in a social vacuum and therefore should be discussed with reference to the ethical negotiations related to consent, since it occurs within a social context of unequally distributed opportunity for freedom and equality.

The following problematisation of consent as negotiated within the subcultural social context of BDSM is inspired by Pateman's (1980, p. 162) insistence on taking into account these 'realities of power and domination in sexual and political lives'. Ethnographic studies of sadomasochism (SM) have problematised the limits of conceptualising the individual by demonstrating how ritual practices within such communities seem to be articulated precisely in the language of individualism (Martin, 2011). The act of consent/non-consent is often seen as an individual responsibility. Against this modern conception of an essential self stands the postmodern deconstruction of the individual subject. Using a Foucauldian understanding, ethical work on the self as part of the governing of souls in modern societies ('governmentality') involves both caring for the self and for others (Foucault, 2003, 2009). Foucault defines this self-formation of the ethical subject as a constant process of acting, monitoring and transforming oneself in relation to particular moral goals and ideals (Foucault, 2001, 1985 [2014]). Carmody (2003, p. 201) builds on Foucault's work when arguing for a discourse on sexual-violence prevention that would acknowledge precisely the ability to ethically negotiate and to establish an 'erotics of consent' across gender and power differences.

\section{Method}

The work in this chapter resembles the process of 'abduction', which Timmermans and Tavory (2012, p. 169) describe as 'the cultivation of anomalous and surprising empirical findings'. As a researcher of IPV with little knowledge of the practice of BDSM, I welcomed the opportunity Tina offered to be led astray, since I hoped to be able to develop novel theoretical insights from her story. In order to understand Tina's attempts to carve out the sexual violence from the BDSM context in her story, I had to expand my initial research project on IPV. Via colleagues and friends, I managed to be introduced to people with an interest in BDSM; through their network, I then recruited seven informants for interviews, in addition to Tina.

These informants were experienced in practising BDSM with life-partners or play partners, and they all had overlapping social networks within local, national and even international BDSM communities. Since the number of interviews had to be limited, I tried to recruit male and female informants with different role preferences in order to analytically explore issues of power exchange from different angles; these roles included 'dominant', 'submissive' (or 'sub') and 'switch', 
a subcultural term for those who sometimes like to dominate and sometimes prefer the role of sub. All informants identified themselves as heterosexual; I found this analytically fruitful, as Tina herself was clear that her story was about abuse in a BDSM relationship, rather than abuse in an LGBTQ relationship. Unlike Tina, the other informants had higher education. Several had academic or even political interest in BDSM: they had read extensively on the subject and had engaged in activism and identity politics to create a more tolerant and 'kink-friendly' society.

I conducted three additional individual interviews with two women (Linda and Mari) and one man (Lukas), all in their 30s. These were qualitative semistructured interviews lasting about two hours, where the informants were asked to describe their personal practice and to explain the role BDSM played in their social lives and as part of their identities. They were also invited, throughout the interview, to reflect on how to draw the line between BDSM and abuse. In addition, three men and one woman (ages 25-40) were interviewed in a group, as friends and fellow members of a BDSM club. Before the group interview, the four participants were asked to read an anonymised short version of Tina's story. In the interview, the story could then serve as a starting point for discussions about how BDSM and sexual violence can be separated. During the interview, I tried to remain passive and not offer my point of view; instead, I listened to their discussions.

The individual interviews were transcribed and analysed. After the group interview, the field notes from the session (and later, an early draft of the chapter) were shared with and commented on by the participants in order to avoid misunderstandings and misinterpretations on my part. I also conducted a follow-up interview with Tina about a year after the first one to get her opinion about my interpretation and analysis of her story. The informants insisted on the importance of their preferred positions (dominant, sub or switch) as well as their gender and sexuality (homo/hetero) for their perspectives on BDSM and sexual violence. At the same time, I was fascinated by the similarities in perspective across such dividing lines as I carved out a shared understanding of the difference between BDSM and sexual violence in the analysis. I understand these similarities from different standpoints as being indicative of high-level social/cultural integration in the larger BDSM community.

In addition to conducting interviews, I observed the participants at BDSMrelated events, such as public lectures during the 2017 Oslo Pride festival, where I engaged in more informal conversations with practitioners. I also searched Norwegian and international BDSM community websites for relevant information on the phenomenon of sexual violence in the BDSM context.

Anonymity is crucial in this project, as the informants most often kept their BDSM practice secret at work or with certain friends and family members. I discussed the issue of anonymity with each interviewee. In addition to using pseudonyms, I have changed several details in their personal stories and quotations. The following includes an analysis of what BDSM essentially is before discussing (through the analysis of Tina's story) what separates BDSM from sexual violence. 


\section{BDSM as perversion, alternative sexuality or lifestyle}

Outsiders often understand BDSM to be either an alternative sexual practice or a form of role-play between consenting adults who suspend their individual lived realities for the sake of erotic enjoyment (Newmahr, 2010). In Foucault's The History of Sexuality (1984), the author describes how sexuality throughout history has become a domain of regulation and social control. According to Foucault, this transformation of sex into discourse endeavours 'to expel from reality the forms of sexuality that were not amenable to the strict economy of reproduction' (1984, p. 36). In a Foucauldian understanding, the 'perversions' included in the BDSM category are products of society's efforts to suppress them. These practices are included in socially constructed hierarchies of sexual value, where some forms of sexuality are valued as 'good', 'normal' and 'natural', whereas others are singled out as 'bad', 'abnormal' and 'unnatural' (Rubin, 1984, pp. 280-281).

In an interview about sex, power and the politics of identity, Foucault discusses sadomasochism (SM) as an attempt to 'de-sexualise pleasure' in a society where traditional understandings of physical pleasure seem limited to eating, drinking and sex (2001, p. 1557). In Foucault's analysis, SM is neither simply a form of alternative sexuality nor a way of releasing suppressed aggression and violence (2001) but rather an alternative way of seeking pleasure. This view seems to agree with the general understanding expressed by the BDSM practitioners I interviewed. A woman I met at a BDSM lecture referred to herself as a 'sadist' in the BDSM context. She told me that over the years, she had concluded that sex for her was about penetration or the touching of genitals. Whether or not sex is included in BDSM play thus depends on the practice, in her understanding. As she explained, 'I actually stopped having sex with my boyfriend many years ago, but I love playing with him'.

There is a growing body of literature on sadomasochism and fetishism in the social sciences that I will not be able to engage with here; see Weinberg (2006) for an extensive review. Practices now often referred to as BDSM have become more visible in the mainstream since the Fifty Shades series (Deller, Harman \& Jones, 2013) and thus more accepted as a way of 'spicing up' one's sex life. Still, from my informants' points of view, BDSM is not reducible to the practice of 'kinky sex'. One of them, Linda, has been part of a BDSM community since she was a teenager and characterises her fellow 'BDSMers' as 'a bunch of friendly geeks'. Linda practices BDSM both in private with her husband and with playing partners at the local club. She identifies herself as switch. 'Please don't get me started on the Fifty Shades hype', she says, implying that her community's BDSM is something else. For Linda, BDSM is a crucial part of her identity as well as an interest she has in common with most of her 'geek' friends and thus not simply a 'practice' or a 'sexual/relational orientation'. Linda's description resonates with Newmahr's findings from an ethnographic study of a US-based SM community that it is: 'an all-encompassing lifestyle that represents liberation from the oppressive plight of the everyman and nurtures identities of marginality' (2011, p. 9). 
From an outsider's perspective, BDSM practices might appear as obeying conventions of power (such as the largely gendered patterns of male dominance and female submission) and perhaps even violence, such as the acceptance of physical pain and bloodshed. The difference lies in the meanings the participants apply (Carlström, 2018). Based on her studies of commercial fetishism and gender power, McClintock (1993, p. 89) argues that despite its apparent servility to traditional power, SM 'performs social power as scripted, and hence as permanently subject to change'. But this opening for change is often understated when insiders draw the line between play and abuse, as if this boundary were fixed and non-negotiable (Wiseman, 1996). People often explicitly refer to the commonly accepted ground rules that BDSM practice should always be 'safe, sane and consensual', or SSC.

\section{SSC and ethical BDSM}

David Stein first introduced the SSC ground rules at an SM-community conference in Washington, DC, in 2000; they have since become a litmus test for 'proper' BDSM. Newmahr (2011, p. 147) expands on this point in her ethnographical studies of SM practices: "“safe, sane and consensual" is what makes SM morally acceptable. The concept thus has come to constitute SM; what is not safe and sane and consensual is not SM, and therefore does not belong in the community'. SSC works as a conceptual tool for acceptance and understanding outside the communities, as well as a way of protecting oneself and each other on the inside. Practitioners consider consent to be crucial. As Newmahr (2011, p. 149) states,

the most serious of the boundaries with which to play, from the perspective of the community, is not the line between life and death, but the edge between consent and non-consent. In the consciousness of the community, deference for a sharply drawn line here separates SM from criminal behavior.

Newmahr's description here illustrates Fanghanels point (2019) that consent in BDSM, the negotiation between risk and trust, must be understood as a practice of community-building, relying on the neoliberal constructions of the autonomous self.

In an interview with Lukas, an experienced sub, he admits that the SSC guidelines do not solve all problems in all situations, but as rules of thumb he finds them 'good to think with'. First, consent to engage in BDSM, according to Lukas, means an enthusiastic expression of free will. In Lukas's understanding, however, the relative health risk in BDSM practice actually implies that consent in itself is not necessarily enough. Accordingly, Lukas defines spanking of the head, stomach, or neck, even if enthusiastically requested, as not safe and therefore not a proper BDSM. He also stresses that BDSM should be practised with a sane mind so that the participants will be able to give their enthusiastic consent. Combining alcohol or drugs with play is not a proper BDSM in his view. In the same logic, Lukas claims that keeping partners socially isolated as part of dominance/submission 
relationships, in a way that hinders them from growing as people, is potentially unhealthy and therefore not a proper BDSM.

Lucas is an idealist and an activist on behalf of his community. The implication of what he says is that ideal BDSM is practised by caring and responsible adults with good social skills and basic knowledge about the human psyche and anatomy. BDSM should be practised with the well-informed intention to please rather than to hurt, within a relational rather than an egotistical logic. Incompetent BDSM playing - or worse, abuse, may be the result when this is not the case. At stake is the boundary between legal, morally acceptable and playful BDSM and illegal, immoral and hurtful sexual violence. Strict, black-and-white dichotomisation between sexual violence and ideal BDSM becomes a way of addressing what outsiders perceive as practices in shades of grey.

Linda, just like Lukas, stresses the importance of belonging to a network of fellow BDSMers so that this clear boundary will not become blurred in practice. When experimenting with technically or psychologically advanced BDSM, people need a place to learn the proper ethics, social rules and language for negotiation and evaluation, and how to take safety precautions and provide proper aftercare. As Linda explains, no matter what role people play (dominant, sub, or switch), they must find what SSC means in their current practice. They must also explore whether their partners' and their own personal boundaries represent 'hard' or 'soft' boundaries: respectively, those that people will not consent to cross at all and those they might cross, from the safe place they have created through negotiations. This distinction between hard and soft boundaries is a way of addressing consent as a question of free will in a floating landscape of explorative pleasure-seeking.

Linda insists on open communication between the parties before, during and after play-sessions, where timing is crucial. When she plays the dominant role with a male sub newcomer at the BDSM club, she never breaks his skin, touches his genitals, or introduces advanced techniques such as breath play without discussing it in advance. An occasion when she has him tied up, hanging upside down, and aroused by the scene is not a good time to ask for permission to touch his genitals. In Linda's understanding, bad timing like this would indeed deprive him of the opportunity to provide consent, in the sense of a conscious expression of free will. She describes how she insists on discussing the details with her playing partners before each session by systematically mapping out each other's hard and soft boundaries, likes and dislikes, and discussing any relevant allergies or other physical conditions. Negotiating BDSM practice at home with her husband is a different situation: they trust each other and can communicate well.

As Carmody argues, much academic discourse on sexual violence has focussed on essentialist ideas about masculinity and femininity, as well as on what is often perceived as 'abnormal' unethical subjects, rather than considering 'how women and men of diverse sexualities do behave as ethical subjects' (2003, p. 211). I see Linda and Lukas as examples of such women and men; in a Foucauldian sense, they seem to include conscious ethical work on the self as part of their BDSM practice. From their point of view, mutual enthusiastic consent is a necessary but insufficient prerequisite for the practice of 'ethical BDSM'. 


\section{Troublesome BDSM}

The tendency among insiders to present BDSM and sexual violence as mutually exclusive is understandable, given the potential social stigma in identifying with BDSM outside of the community. The International Classification of Diseases and Related Health Problems (ICD-11) is a good illustration of existing hierarchies of sexual practices in society (Rubin, 1984). Until June 2018, 'fetishism', 'sadism' and 'masochism' were included in chapter F65 of ICD-11 as forms of 'mental disorders of sexual preference'. According to a revision based on current scientific evidence (Reed et al., 2016, p. 213), these diagnoses were removed, and the new category 'coercive sexual sadism disorder' was introduced 'to clearly distinguish this disorder from consensual sadomasochistic behaviors that do not involve substantial harm or risk'. WHO's recent decision to follow the Nordic countries in removing the diagnoses implies that 'consensual sadomasochism' (or BDSM) will now be considered a sexual practice; 'sexual sadism' aimed at a non-consenting person, in contrast, will still be considered a form of mental disease. The key concept in this distinction between an acceptable sexual preference and a mental disorder is consent.

According to Conly (2004, p. 98), the legal concept of rape traditionally involves two elements: the perpetrator's use of force and the victim's lack of consent. Because use of force is often part of the game in BDSM, mutual consent given by healthy adults has become a major distinction between BDSM (as a legal sexual practice) and illegal sexual violence; see Smart (1995) for a problematisation of earlier jurisprudence in the UK. In a Norwegian court case from 2013 (LH-2012-160658), a man was acquitted for charges of 'grossly negligent sexual assault' in a case where BDSM 'rape play' had resulted in an indictment of rape on the part of a male dominant. The actual play session had been filmed and thus was able to be used as evidence in court. The male dominant/offender asked the female submissive/victim to confirm that she had agreed to be part of a role-play where she was to be raped (including being hit in the face and held down). The woman consented on tape, and during the filmed play session/rape, she screamed 'No', sobbed and asked the man repeatedly to stop. Their mutual agreement beforehand had included the use of a safe word ('red') in case either wanted to end the play session. Because the woman never uttered 'red' on tape, the court could not prove beyond a reasonable doubt either that she had withdrawn her consent or that the man had understood that she wanted him to stop. In other words, the court could not prove that it was dealing with 'non-consensual sexual sadism' rather than 'consensual sadomasochism'; therefore, the male dominant/ offender was free to go.

The international BDSM social movement insists on free mutual consent as the signature of 'healthy BDSM', regardless of gender, class or ethnicity. In actual practice, however, gender is often a crucial factor, as shown in Carlström's studies (2017) among Swedish practitioners who work hard to reconcile gender equality with the power structures of BDSM. As Carlström shows, 
radical feminist theorists tend to see BDSM practices as fundamentally misogynistic products of patriarchy that eroticise power differences of gender, regardless of who dominates whom on the individual level. The BDSM movement, in contrast, is inspired by more 'sex-positive' queer theory, with a different approach to power and consent.

West (2008) makes a point of how both feminist and queer perspectives can be used in obscuring the distinction between consenting and non-consenting sex, pushed to extremes: 'from either perspective, then, consent fades in significance as power looms: for radical feminists, sexual power is coercive with or without consent, and for queer theorists, sexual power is transgressive and pleasure-enhancing, with or without it' $(2009$, p. 19). In sex crime legislation, the concept of consent strictly means giving permission (and thus is under the influence of specific circumstances), whereas a feminist understanding of the concept looks at consent as 'an aspect of relational sexual integrity and autonomy' (Larcombe, Fileborn, Powell, Hanley \& Henry, 2016, p. 614). A common feminist critique of legal definitions of rape has precisely been that these definitions do not always consider the structural inequalities and particular contexts that shape all sexual encounters.

Mari, a woman in her 30s who practises BDSM exclusively in her private home, provided a similar explanation for why she tries to keep her distance from her former BDSM community. To her, the ideals of gender-equal BDSM between consenting adults are not always reflected in actual practice. She uses the example of respect for a stop-word as a way of withdrawing consent: an imperative social norm in BDSM. Mari has experienced how esteemed male dominants get away with breaking this rule because it is up to his female sub to prove that he has indeed disrespected her attempt to stop him. As Mari says:

As a feminist, I find this community problematic, and that's partly why I wish not to be part of it: because so many pretty words are spoken about consent and all that, but in reality, my experience is that these boundaries are fluid. If you go to [a BDSM club] and sit there in the bar, and someone comes up to you and pulls your hair, for instance, then you haven't given your consent. And people say, 'That's just flirting'.

In BDSM, just as in life in general, consent becomes a problematic issue in practice precisely because the consent depends on the particular social context of unequal power relations. BDSM communities often frown upon drawing attention to problematic experiences related to consent. According to Mari, people who speak out against fellow BDSM community members' disrespect of the ideal of mutual and enthusiastic consent tend to experience being 'frozen out' as a result (see also Barker, 2013). There is no reason to believe that feminist attitudes differentiate significantly between sadomasochists and non-sadomasochists (Cross \& Matheson, 2006). That is precisely Mari's point: BDSM takes place within a larger social context characterised by gendered power differences. 


\section{When BDSM becomes violent: Tina's story}

Tina's story is a good example of how the problem of consent encompasses both BDSM ideals and the performative act of giving permission or saying 'yes'. At the age of 23, Tina contacted 'Emma' (10 years older) on Fetlife, the BDSM equivalent of Facebook. Tina was interested in sex rather than something more serious, and Emma was already in a relationship with another woman who accepted her wish to have a playing-partner/girlfriend on the side. During the following year, Tina spent most of her spare time at the couple's house and with their friends, as well as with Emma on her own.

Within the BDSM framework, Tina and her former girlfriend seemed to take their negotiations over practice to ensure mutual consent seriously. Tina explains:

When you're doing something that outside of this framework is basically violence, it's important that you make agreements ... BDSM has a lot of rules: both the general ground rules saying that it has to be safe, sane, and consensual, and ... the personal preferences - your own boundaries. If you're to benefit from pushing your boundaries - something that many people take pleasure in - you have to do it based on mutual trust and communication.

Tina points to a fundamental dilemma in BDSM: between control obtained through the establishment of general rules (SSC) and personal boundaries and the willingness to push these boundaries. This situation is a matter of finding the right balance between taking precautions and taking risks; for many people, the element of risk seems to be precisely what makes BDSM more interesting than 'vanilla' sex. Consent in this context is a way of solving this dilemma. Consent then operates at different levels: as part of the negotiation of rules and boundaries in each situation and in the negotiated willingness to engage with a particular partner (or with BDSM play in general).

Although both Tina and Emma preferred domination to submission, Tina agreed to let Emma teach her how to become a proper dominant through the submissive role. Emma suggested that they discuss sexual preferences and boundaries in writing 'so that we both know what we want', she said. During the first few months, Tina and Emma mostly engaged in physical and sexual BDSM play and spent time working out compromises so that both would benefit. After a few months, Tina agreed to try more extensive psychological dominance during her everyday life. In the beginning, Tina found these more boundless and fluid mental aspects of BDSM exciting. As Emma's servant, Tina was to address her as 'Mistress' and could not touch her without permission. Emma particularly liked when Tina showed off her bruises and scars as signs of Emma's ownership of her. Other ways for Tina to make Emma happy included wearing 'butt plugs' at work, wetting herself in public, or drinking her own urine as ways of proving her willingness to please her 'domina'. Eventually these tasks, all seemingly common in BDSM, started to make Tina more and more uncomfortable. It became increasingly difficult for her to do her job 
properly or to spend time with her own friends - people whom Emma often told her were a bad influence.

As a dominant, Emma expected Tina to email her a description of her tasks for the coming day every night before going to sleep, including sexual activities. One evening about a year after they had first met, Tina fell asleep on the couch without sending this mandatory email to her mistress. When they met the following day, Emma was 'cold as stone', as Tina describes her, and she horsewhipped Tina. Tina was terrified, as she felt the boundary between play and reality was collapsing and that she had lost control of the situation. As is common in BDSM practice, Tina and Emma had agreed on a safe-word for each to use to revoke their consent if things went too far. Looking back at what happened that particular morning, Tina says:

Of course, I could've used the safe-word, and then she would've stopped. But then again, I was convinced that if I'd said 'red', our relationship would have ended there. She felt that she did all this to me as a favour. Or at least that's what she would've said afterwards.

Shortly after this incident, Tina admitted to herself and to Emma that she had fallen in love with her. Because Emma was unwilling to leave her partner, they decided to end their relationship. During the three years that have passed since that time, they have had no contact other than a few messages on social media. But Tina is convinced that Emma is stalking her through anonymous profiles on social media by sending disturbing messages and vague threats. During the first few months after the breakup, Tina became increasingly confused, anxious and depressed. Suddenly she was afraid to leave her apartment without doing a proper risk analysis: which streets were safe and which social venues would put her at risk of bumping into Emma, or her girlfriend or friends.

\section{Drawing the line through shades of grey}

Even before Tina met Emma, BDSM had become a fundamental trait of her personal and social identity; their relationship was defined within this framework. BDSM is still part of who Tina is and wants to be, and therefore, it is crucial for her to define what happened between her and Emma as 'something else'. The overarching problem in Tina's struggle to make sense of what happened to her appears to be the disparity between black-and-white BDSM ideals and the grey areas of actual practice. This situation has led Tina into a constant dichotomisation between legitimate BDSM and illegitimate sexual violence. The BDSM play that she was part of - at least from her own understanding in retrospect - did not feel safe, sane and consensual and therefore could not have been BDSM. But beyond BDSM, Tina has difficulty finding the right words to describe what happened. Was this violence? If so, was the violence physical, sexual or psychological? At what time did the violence start, and is it in fact still going on? 
At the time of the first interview, Tina seemed to have made up her mind, more or less: she claimed to have been exposed to violence by intent in an intimate relationship. It was the consequences of what had happened - the anxiety and depression she had suffered in the period after the relationship ended that made Tina question Emma's moral character and intentions:

I've realised since then that she never did this for me. All that talk about teaching me ... I think she did it to put me in a situation where she could take advantage of me. Where she was allowed... allowed to hit me.

The idea of Emma exploiting the BDSM framework for her own purposes was not helpful for Tina, as she still had to live with her own 'consent' to the actions whose aftermath later caused her so much pain. Using a safe-word essentially means revoking one's consent, and she never used it; she never said 'red'. In Tina's story, consent was a state of mind and was the constant as her initial BDSM experiences over time turned into experiences of sexual violence. The burning question in her story that she constantly returned to was: 'How could I have put myself in such a situation?' She repeatedly accepted and normalised Emma's dominance out of love or fear, constantly pushing her own boundaries until they no longer existed. What exactly does consent mean under such circumstances?

\section{Consent and responsibility}

While power and domination are central aspects of all social relations (Foucault, 1984 [2001]), we may understand violence as a particular kind of power and domination where legitimacy is contested. As Riches notes (1986, p. 10):

the main ambiguities, and therefore misunderstandings, will certainly come from people's inability always to spot acts of hurt which are primarily meant as playful or ritualized, as opposed to those which are directly serious in intent'.

During the interview with several friends from a BDSM club, they debated the question of legitimacy related to intent in relation to the anonymised version of Tina's story.

Just as in my conversations with Tina, the discussion in the group interview was coloured by the participants' insistence on responsibility related to the issue of consent in the story. One of them, a male dominant, described the relationship in the story presented as 'clearly abusive', and claimed that he would never let his sub consent to play on such premises. He particularly questioned Emma's apparent lack of interest in checking in on Tina, ensuring that she was ok emotionally. In his view, Emma had been responsible for creating a coercive context in which free consent had become impossible. Because safe BDSM does not actually exist, this man argued, all participants - and the dominant in particular - must take the issue of risk seriously to avoid people getting hurt. 
Another participant, a submissive male, disagreed with his friend; he claimed that Tina herself had been responsible for this situation and referred to it as 'self-abuse, plain and simple'. As a fellow sub, he insisted on Tina's responsibility for protecting her own boundaries and integrity during BDSM play. Whenever she found that she was unable to do so - for instance because she had unintentionally fallen in love with her mistress - he felt that she should have stopped practising.

The question that all the informants in their different ways tried to answer was one that I never asked them myself: Whose responsibility is it when someone consents to unwanted BDSM play? This is not an issue that can easily be agreed upon based on BDSM moral codes alone. In general, the informants seemed fairly ambiguous when talking about the risks related to BDSM: they drew strict lines between BDSM and sexual violence based on the general SSC guidelines while also engaging in a nuanced problematisation of the same distinctions. They also explained that fellow BDSMers frequently talk about their practice in terms of violence; they even claimed that BDSM is indeed a form of violence. They all seemed to understand the practice of BDSM as 'playing with fire', where the risk of harm is inevitable. They explicitly shared my understanding of risk assessment and safety precautions in BDSM as being more often aimed at physical rather than mental aspects. They explained that, because of the stigmatisation from outside BDSM as a former psychiatric diagnosis, psychological troubles related to the practice tend to become taboo on the inside.

\section{Conclusion: fetishising consent to manage stigma?}

In conclusion, based on the above discussion, Tina's difficult situation is not only related to what happened between her and Emma but also to the general social context and the internal and external mechanism of the stigmatisation of a sexual minority. The social construction of sexual violence in the context of BDSM somehow turns 'abusive BDSM' into an anomaly (Douglas, 1984): a phenomenon that falls between cultural categories and is a potential threat to the social order. Tina's story represents such a threat, both to her and to her fellow BDSMers, since she claims to have been exposed to BDSM as 'consensual violence'.

West addresses the phenomenon of consensual sexual harm: 'at most, the consensuality of the transaction implies only that if the transaction is harmful, or bad, it is so for reasons other than the harmful consequences that flow from the exercise of coercion or force' (2009, p. 20). Because consent has never been a good proxy for well-being, West argues, we should not treat it as such. We should indeed 'quit fetishising consent' (2008, p. 15), she points out, when exploring the frontiers of sex and violence within academic discourse.

The verb 'to fetishise' has two meanings. First, it refers to making something the object of a sexual fetish; second, it refers to having an excessive and irrational commitment to something. During the process of analysing BDSM as ideal and practice, I have come to think of consent as something that could easily be fetishised in the latter sense within this distinct subculture in which sexual fetishism is 
encouraged. I find that people's commitment to consent in BDSM communities might cause serious blind spots concerning their common responsibility in preventing BDSM play from becoming abusive. According to the above-mentioned shift in sexual violence prevention discourse, this fetishising of consent within BDSM seems to be part of a much larger trend in societies and political fields where individualist ideologies dominate, to the point that they are taken for granted. Within such logics, because of the insistence on personal responsibility, the individual tends to be held responsible for consenting to unwanted sex.

Because of the risk related to the potentially coercive circumstances of BDSM, the necessity for nuanced ethical negotiation in practice - particularly in relation to consent - is perhaps more urgent than elsewhere. This study has shown that BDSM as a subculture is indeed characterised by particularly sophisticated ethical negotiations over issues concerning sexual practices and consent: likely much more so than in mainstream sexual practice. People who practise BDSM as part of a community appear to be aware of the risk and social responsibility involved; the widely accepted ground rules - safe, sane and consensual - are precisely meant to prevent people from turning pleasure into abuse. Alongside the rather problematic fetishising of consent, I sense a cultivation of skilful risk management for the benefit of both the group and the individual. The political and academic field of sexual violence might find the potential for several new insights within this universe of rigid obedience to rules alongside the simultaneous pursuit of creative flexibility.

\section{Acknowledgements}

This study was conducted at the Norwegian Centre for Violence and Traumatic Stress Studies and funded by the Norwegian Ministry of Justice and Public Security. The author would like to extend a warm thanks to Yngvil Grøvdal for allowing this little detour from the main research project, and to Ingvild Bergom Lunde for leading the way. Thanks also to informants in the BDSM community for opening doors and giving valuable comments on an early draft, and to the editors for their important contributions towards this final version.

\section{References}

Barker, M. (2013). Consent is a grey area? A comparison of understandings of consent in Fifty Shades of Grey and on the BDSM blogosphere. Sexualities, 16(8), 896-914. doi: $10.1177 / 1363460713508881$

Beres, M. A. (2014). Rethinking the concept of consent for anti-sexual violence activism and education. Feminism \& Psychology, 24(3), 373-389. doi:10.1177/0959353514539652

Cahill, A. J. (2001). Rethinking rape. Ithaca, NY: Cornell University Press.

Carlström, C. (2017). Gender equal BDSM practice: A Swedish paradox? Psychology \& Sexuality, 8(4), 268-279. doi:10.1080/19419899.2017.1383302

Carlström, C. (2018). BDSM - The antithesis of good Swedish sex? Sexualities, 0(0), 1-18. doi: $10.1177 / 1363460718769648$ 
Carmody, M. (2003). Sexual ethics and violence prevention. Social \& Legal Studies, 12(2), 199-216. doi:10.1177/0964663903012002003

Conly, S. (2004). Seduction, rape, and coercion. Ethics, 115(1), 96-121. doi:10.1086/421981

Cross, P. A., \& Matheson, K. (2006). Understanding sadomasochism: An empirical examination of four perspectives. Journal of Homosexuality, 50(2-3), 133-166. doi:10.1300/ J082v50n02_07

Deller, R. A., Harman, S., \& Jones, B. (2013). Introduction to the special issue: Reading the Fifty Shades 'phenomenon'. Sexualities, 16(8), 859-863. doi:10.1177/1363460713508899

Douglas, M. (1984). Purity and danger: An analysis of the concepts of pollution and taboo. London: Ark Paperbacks.

Fanghanel, A. (2019). Asking for it: BDSM sexual practice and the trouble of consent. Sexualities, 0(0), 1-18. doi:10.1177/1363460719828933

Foucault, M. (1984). The history of sexuality 1: An introduction (Vol. 1). Harmondsworth, UK: Penguin.

Foucault, M. (1984 [2001]). L'ethique du souci de soi comme pratique de la liberte. In D. Defert \& F. Ewald (Eds.), Dits et écrits II, 1976-1988 (pp. 1527-1548). Paris: Quarto Gillimard.

Foucault, M. (1985 [2014]). Morality and practice of the self. In D. Fassin \& S. Leze (Eds.), Moral anthropology: A critical reader (pp. 41-45). New York: Routledge.

Foucault, M. (2001). In D. Defert \& F. Ewald (Eds.) Dits et écrits, 1954-1988. Paris: Gallimard.

Foucault, M. (2003). 'Society must be defended': Lectures at the Collège de France, 1975-76. New York: Picador.

Foucault, M. (2009). Security, territory, population: Lectures at the Collège de France, 1977-78. In M. Senellart, F. Ewald, A. Fontana, \& G. Burchell (Eds.), Michel Foucault: Lectures at the College de France. New York: Picador.

Gavey, N. (2005). Just sex? The cultural scaffolding of rape. London: Routledge.

Gunnarsson, L. (2018). 'Excuse me, but are you raping me now?' Discourse and experience in (the grey areas of) sexual violence. Nora: Nordic Journal of Feminist and Gender Research, 26(1), 1-15.

Hickman, S. E., \& Muehlenhard, C. L. (1999). 'By the semi-mystical appearance of a condom': How young women and men communicate sexual consent in heterosexual situations. Journal of Sex Research, 36(3), 258-272.

Larcombe, W., Fileborn, B., Powell, A., Hanley, N., \& Henry, N. (2016). 'I think it's rape and I think he would be found not guilty': Focus group perceptions of (un)reasonable belief in consent in rape law. Social \& Legal Studies, 25(5), 611-629.

Martin, R. (2011). Powerful exchanges: Ritual and subjectivity in Berlin's BDSM scene. ProQuest Dissertations Publishing. https://dataspace.princeton.edu/jspui/handle/88435/ dsp01qz20ss51g

McClintock, A. (1993). Maid to order: Commercial fetishism and gender power. Social Text, 37, 87-116. doi:10.2307/466262

Newmahr, S. (2010). Power struggles: Pain and authenticity in SM play. Symbolic Interaction, 33(3), 389-411. doi:10.1525/si.2010.33.3.389

Newmahr, S. (2011). Playing on the edge: Sadomasochism, risk, and intimacy. Bloomington: Indiana University Press.

Pateman, C. (1980). Women and consent. Political Theory, 8(2), 149-168. doi:10.1177/ 009059178000800202

Reed, G. M., Drescher, J., Krueger, R. B., Atalla, E., Cochran, S. D., First, M. B., ... Saxena, S. (2016). Disorders related to sexuality and gender identity in the ICD-11: 


\section{Monika Grønli Rosten}

Revising the ICD-10 classification based on current scientific evidence, best clinical practices, and human rights considerations. World Psychiatry, 15(3), 205-221. doi:10.1002/ wps. 20354

Riches, D. (1986). The phenomenon of violence. In D. Riches (Ed.), The anthropology of violence (pp. 1-27). Oxford, UK: Blackwell.

Rubin, G. S. (1984). Thinking sex: Notes for a radical theory of the politics of sexuality. In C. Vance (Ed.), Pleasure and danger: Exploring female sexuality (pp. 267-319). Pandora: London.

Smart, C. (1995). Law, crime and sexuality. London: Sage.

Timmermans, S., \& Tavory, I. (2012). Theory construction in qualitative research. Sociological Theory, 30(3), 167-186. doi:10.1177/0735275112457914

Weinberg, T. S. (2006). Sadomasochism and the social sciences: A review of the sociological and social psychological literature. Journal of Homosexuality, 50(2-3), 17-40. doi:10.1300/J082v50n02_02

West, R. (2008). Sex, law and consent. Faculty Working Paper, Georgetown University Law Center. https://scholarship.law.georgetown.edu/cgi/viewcontent.cgi?referer=https:// www.google.com/\&httpsredir=1\&article=1073\&context=fwps_papers

Wiseman, J. (1996). SM 101: A realistic introduction. San Francisco: Greenery Press.

World Health Organization (WHO). (2002). World report of violence and health. Geneva: WHO. 


\title{
4 Understanding unwanted sexual touching
}

\author{
A situational approach
}

\author{
Kari Stefansen
}

\section{Introduction}

Situations involving unwanted sexual touching are analysed in this chapter in an effort to enhance our understanding of the social dynamics of this particular form of invading behaviour against girls and young women. The analysis is grounded in a situational perspective (which I will expand on later) that draws on Collins's (2009) micro-sociological approach to the study of violence. On the background of that analysis, I will discuss some of the wider ramifications or cultural consequences of the phenomenon of unwanted touching, with a focus on the harm such behaviour causes at the collective level. The starting point for this discussion is the idea that unwanted sexual touching, like rape and other forms of sexual violence, represents both 'a personal and systemic attack' (Munro, 2010, p. 26). The relevance of an analysis of unwanted sexual touching in a book about rape is that such an analysis contributes to our understanding of the boundaries and harm of sexual violence - issues that are high on the agenda among numerous socio-legal studies on rape law (e.g. McGlynn \& Munro, 2010). It is important to explore the harm and boundaries of sexual violence more generally, however, and not exclusively from a penal perspective, where phenomena such as intent and culpability are often placed in the foreground. My interest in this chapter is instead to draw our attention to the social aspect of unwanted sexual touching, particularly the way it unfolds in different interactional settings. The analysis highlights how context shapes sexual behaviour, an issue that is understudied in relation to sexual violence (Khan, Hirsch, Wamboldt, \& Mellins, 2018).

The situations I explore involve acts that in common parlance are referred to as groping, fondling, feeling up and similar terms. These are forms of unwanted and unsettling sexualised touching that may happen everywhere - on the bus, at school, at work and during parties and other social events. Viewed from a penal or hierarchical perspective on sexual violence, such acts may represent 'minor events' (Smart, 1995, p. 222) compared to violent rape, but they are prevalent and part of the everyday sexism that many girls and women encounter and must handle. Nationally representative studies among youths in Norway (the empirical context of my analysis) indeed confirm that unwanted touching is 


\section{Kari Stefansen}

widespread in the Nordic context, despite increasing efforts in recent years to prevent sexual violence among the youth population (for example, see Skilbrei \& Stefansen, 2018). The lifetime prevalence rates for 18-19-year olds are around 25\% among girls and 6-7\% among boys (Mossige \& Stefansen, 2007, 2016); the annual rates are correspondingly high. In a study among 16-18-year olds, $21 \%$ of girls and $9 \%$ of boys reported having experienced unwanted sexual touching in the past 12 months (Bakken, 2017). The referred-to studies among older youths were conducted eight years apart but showed similar rates, thus indicating that unwanted sexual touching (and sexual violence in general) is stable and frequent among youths in Norway. The consistently higher numbers for girls serve as a reminder that sexual violence is highly gendered, even if it also affects boys.

The analysis in this chapter is restricted to girls' experiences of unwanted touching, for the simple reason that the empirical material I analyse contains too few descriptions from boys to allow for a meaningful exploration. I analyse descriptions of unwanted touching that happened to girls after the age of 13 and that involved boys or young men of the same age as the girl or a few years older. Hence, the focus of attention is youth-related incidents of unwanted sexual touching, not childhood sexual abuse. The descriptions were gathered as part of a large-scale survey study conducted among students in the final year of upper secondary school (18-19-year olds). The descriptions are short and typically comprise two or three sentences, which means that the data are 'thin' compared to other types of qualitative data (such as interviews or fieldwork) that yield more complex and 'thick' data on the object of inquiry.

Other researchers have used this type of data to gain knowledge about different aspects of sexual encounters and transgressions. Examples include gendered patterns in regretting consensual sex (Krange \& Pedersen, 1999), women's labelling of rape and sexual assault (Kahn, 2004; Kahn, Jackson, Kully, Badger, \& Halvorsen, 2003; Stefansen \& Smette, 2006) and gendered aspects of incapacitated sexual assault (Stefansen, Överlien, \& Frøyland, in preparation). These studies, much as I do in the current chapter, simultaneously acknowledge the limitations of this type of data and make the epistemological claim that short descriptions of sexual and sexualising encounters that offer only glimpses of social interactions and contexts nevertheless can provide possibilities for the theorisation of the phenomenon in question. The potential of short descriptions in this respect relates to the fact that they are gathered as part of large-scale and often representative surveys; thus, they likely capture close to the full range of experiences related to the phenomenon of interest. The underlying idea of the analysis in this chapter is that a careful empirical patterning of unwanted sexual touching can contribute to an understanding of the social and situational dynamics involved in producing such incidents, which in turn can further scholarly discussions on the boundaries of sexual violence and the cultural effect of minor transgressions. In this sense, I follow up on the call from Fileborn $(2016$, p. 7$)$ to reignite scholarly discussion on 'the broader spectrum of sexually violent and unwanted behaviours'. 
The starting point for my analysis is that unwanted touching needs to be unpacked before we can understand its social dynamics, which means taking into account that unwanted sexual touching is and does different things in different situations. In the current literature, unwanted sexual touching is often understood in terms of unwanted sexual attention or sexual harassment. Within this strand of research, the spatial dimension of such transgressions has been the most common subject of attention. Specialised studies in the literature have focussed on sexual harassment on the street (Vera-Gray, 2016), in bars and other social-drinking venues (Graham, Bernards, Abbey, Dumas, \& Wells, 2017; Kavanaugh, 2013; Tinkler, Becker, \& Clayton, 2018), in schools and university campuses (Gillander Gådin \& Stein, 2017; LeMaire, Oswald, \& Russell, 2016) and online (Megarry, 2014; Thompson, 2018). Very few researchers have looked into the relational aspect of unwanted sexual attention in combination with spatiality, i.e. the socio-spatial contexts of unwanted sexual touching. In the current chapter, I take such contexts to represent different situational circumstances for unwanted sexual touching. I situate my analysis within the scholarship on sexual violence, to be discussed next.

\section{Theorisations of sexual violence}

To explore unwanted sexual touching means to explore the boundaries of sexual violence (cf. Fileborn, 2016). But what counts as sexual violence? Two main approaches to this question are the 'conceptual' and 'cataloguing' approaches (Munro, 2010, p. 17). Rather than listing specific behaviours that constitute sexual violence, the focus of the conceptual approach, which guides my analysis, is on what acts of sexual violence harm (Skilbrei \& Stefansen, 2018). Stang Dahl (1994), for instance, defines sexual violence as acts that violate a person's 'gender freedom', i.e. the right to decide for oneself when and how to engage in sexual interactions and how far these interactions can go. Kelly articulates a similar position, seeing sexual violence as acts that take away someone's 'ability to control intimate contact' (1988, p. 41). Both conceptualisations depart from a normative theory of sexual integrity or self-determination and agency as that which is harmed or compromised by sexual attacks (and which legal regulations today aim to protect). The same is the case in Cahill's sexual-ethics perspective $(2014,2016)$. Cahill's theorisation (to which I will return shortly) is especially relevant for my purposes because it also offers conceptual tools that encompass the 'grey area' of sexual or sexualised encounters those encounters that represent neither sexual violence nor reciprocal or wanted interactions but are located somewhere between the two.

So far, I have dealt with theorisations of acts of sexual violence. To facilitate discussion on the wider ramifications of unwanted sexual touching, I will also draw on theorisations of the collective aspect of sexual violence. One idea is that sexual violence can be understood as compromising what Cornell (2007, p. 230) calls the 'imaginary domain', meaning 'the moral and psychic space we all need in order to come to terms with who we are as sexuate beings and to 


\section{Kari Stefansen}

have the chance to claim our own person as a sexuate being'. ${ }^{1}$ The implication, which I draw from Bjørnholt and Helseth's reading (2019) of Cornell (1995), is that sexual violence compromises women's imaginary domain through the gendered power structures such violence upholds. Their interpretation echoes Munro's point (2010, p. 26), mentioned earlier, that rape (and sexual violence in general) simultaneously represents an attack on the personal and the cultural/ systemic levels. The systemic dimension of sexual violence implies that sexual violence may cause harm that transcends the harm experienced by those who are directly affected. When I later discuss the concept of a gendered 'phenomenology of fear' (Cahill, 2001, p. 143), I will draw on this line of thought. Below I expand on the situational perspective that has guided the empirical analysis.

\section{Analytical approach: the situational perspective}

The analysis in this chapter draws inspiration from Collins's (2009) microsociological approach to the study of violence. Collins claims that in order to understand the dynamics of violence, researchers should not study violent individuals, but violent situations. As Collins argues, 'we [must] seek the contours of situations, which shape the emotions and acts of individuals who step inside them', which means to 'put the interaction in the center of analysis, not the individual, the social background, the culture or even the motivation: that is to say, look for the characteristics of violent situations' (p. 1). Thus, researchers must look for the situations that occur within forms of violence, and compare them. I aim to do this in my analysis by identifying and comparing the sociospatial contexts in which unwanted touching occurs. Socio-spatial contexts, then, are defined by their normal flow of meaning or underlying social contract. It makes a difference, for instance, if the touching has happened in a 'sexualised space' (Fileborn, 2016; Kavanaugh, 2013) or in a more 'neutral' zone, for example at school or work. Hence, the use of the situational perspective allows for sensitivity towards the fluidity of unwanted sexual touching. This is an important consideration, since situations involving unwanted touching may shift rapidly from something wanted to unwanted, and vice versa (Demant \& Heinskou, 2011). The same act of unwanted touching may also be fundamentally ambiguous - wanted and unwanted at the same time. It may, for instance, both ignite feelings of devaluation and fear and work as a confirmation of a girl's sexual attractiveness and social standing (Stefansen, Smette, \& Bossy, 2014).

With this background, I understand unwanted sexual touching as acts that can potentially disrupt some of the normal flow of meaning that takes place in a given situation. The focus of the analysis will be on how such disruptions happen or are actualised and how they can be understood in terms of sexual violence. To that end, I will apply Cahill's sexual-ethics framework (2014, 2016). Cahill argues that sexual situations can be differentiated according to the degree of agency and possibility to affect the situation that the interaction allows for those involved. She identifies two main situations: 
ethically acceptable sex (or 'just sex') and ethically problematic sex, or 'unjust sex'. In ethically acceptable sex, both parties have agency, meaning that they both have recognised will in the situation, while in ethically problematic sex, the agency of one person is compromised. Unethical sexual acts do not necessarily represent a total undermining of the victim's agency, however, as some unethical acts allow for some form of agency. In these cases, the act does not constitute sexual violence. I will discuss how the different situations in which unwanted touching occurs can be understood, in light of Cahill's conceptual tools.

In the next section, I turn to the empirical basis of my analysis. Collins (2009, p. 2) argues that to 'see the patterns of confrontation, tension and emotional flow, which are at the heart of the situation where violence is carried out', researchers need data that will capture the details of the situation, preferably via direct observation. Given that such observation is seldom possible, video, reconstructions or observations of violent events are valid options. My data are a form of observation - from the perspective of the affected girl. Because they lack depth and detail, the analysis is explorative rather than comprehensive. This means that I can only sketch out the contours of situations in which unwanted touching occurs and infer the meaning for those involved and the dynamics related to the disruptive act.

\section{Methods, data and categorisations}

The short written descriptions I analyse were gathered through a large-scale survey study conducted among students in their final year of upper secondary school, aged 18-19 years. A representative sample of 67 upper secondary schools across Norway were recruited. The sample of schools was provided by Statistics Norway following a two-stage sampling procedure. All eligible upper secondary schools were allocated to five geographical regions to ensure participation from the whole country and then stratified within each region into three categories: academic track only, vocational track only and combined. The participating schools were drawn according to strata size to ensure proportional allocation. All final-year students in each school were invited to participate. A total of 7,033 students accepted, giving a response rate of $77 \%$.

The participants answered a questionnaire about different types of victimisation, including sexual victimisation, broadly defined. The questionnaire was administered in the classroom and with a teacher present. The participants answered yes or no to a set of questions about unwanted touching, attempted rape and rape before and after the age of 13. Any participants who indicated at least one such experience were asked to describe in their own words what had happened and the people involved (without providing names) for the first and last incidents. This material consisted of approximately 1,000 short, written descriptions. Among these descriptions, 164 were relevant for the analysis presented in this chapter. Among these descriptions, 97 were related to assailants whom the girl had defined as either a friend or an acquaintance; 10 were related to a boyfriend and 57 to a stranger. 


\section{Kari Stefansen}

The aim of the analysis was to identify situations of unwanted touching. To that end, I first grouped the descriptions according to the girl's relation to the assailant: whether he was a friend or acquaintance, a boyfriend or a stranger. Within these categories of relations, I identified where and how the unwanted touching had occurred. Taken together, these elements provide insights into the different interactional dynamics of unwanted touching. The labelling of each type of unwanted sexual touching is intended to capture the meaning of the different acts and to also enable analysis of the fluidity of the phenomenon. The forms of unwanted touching from friends and acquaintances that I conceptualise in this chapter are also described in Stefansen et al. (2014).

\section{Situations involving friends/acquaintances and boyfriends}

Friends and acquaintances were the most frequently occurring type of relation in the material. One distinct type of unwanted sexual touching from friends and acquaintances happens in public or semi-public places with other youths present. I use the label performative touching for these instances because the phrase highlights the relationship between the act of unwanted touching and the flow of meaning in a given situation. I interpret the acts as representing a form of role-play related to heterosexual stereotypes.

The typical scenario for this type of performative touching is the public space of schoolyards or hallways in lower secondary school, and situations where a boy suddenly reaches out and touches a sexualised area of a girl's body, for instance her breasts or thighs. The quotes below are illustrative:

He touched my boobs in recess, which I didn't want.

A group of boys our age touched the girls in middle school against our will especially one person, who was a year older than us. He held us really hard while he touched us.

Fondling by people my age and maybe a bit older at a youth club.

A classmate touched my breasts, and it was pretty obvious: right in the middle of the school hall.

These acts may be understood as being directed towards an audience of other boys as much as towards the girl; hence, the interaction in the situation is more between the boys than between the particular boy and girl involved in the sexualtouching incident. On this premise, these acts can be understood as representing performances of a sexualised form of male aggressiveness that reproduce ideas about masculinity and gendered hierarchies (Lahelma, 2002; Robinson, 2005).

The data include descriptions of similar behaviours from friends and acquaintances at parties or clubs, i.e. in arenas associated with romantic or sexual initiatives. I see these advances as being different from performative touching. Because they happened in sexualised spaces, they have a more explorative quality. The typical 
scenario is of a boy reaching out and signalling interest but being rejected by a girl. The premise for this interpretation is that while the particular act is unwanted (and may come as a surprise to the girl), sexual or romantic advances are to be expected in these situations, and they therefore represent part of the normal flow of meaning or general social energy or 'vibe'. I label these acts explorative touching. The following quotes describe typical situations:

He made a pass at me; it wasn't much. He stopped right away when I told him off.

He touched my thighs and sat down next to me. Before he had a chance to embrace me, I stood up. I was with my friends the rest of the evening.

I was at a birthday party. We were alone outside, so he made a pass at me.

In a sense, this form of unwanted sexual touching resembles what Kavanaugh (2013) describes as transgressions that stem from 'competing definitions of the situation' (p. 26). The situations represent a form of 'scorned sexual advance' (p. 26) that follows from a boy's misinterpretation of a girl's behaviour as signalling openness to some kind of contact. Kavanaugh's description is perhaps too simplistic, however. The notion of explorative touching highlights how such advances, while out of sync with the person they are directed against, at the same time are spurred by and in sync with the flow of meaning and interaction that defines the situation.

But some of the descriptions from parties or clubs in my data challenge the interpretation of all acts of unwanted touching in sexualised spaces as being explorative or inviting. Some acts of unwanted touching in these spaces seem to be more impulsive and random, and they happen in situations with other people present, as the following quotes show:

I was on the dance floor at a club when a guy came up behind me and touched me. I pushed him away.

Nothing serious, but sometimes people pass you and touch you at parties and so on.

[I was] felt up at a club on the dance floor (my breasts, between the legs, and my hips) despite me saying no.

Kavanaugh (2013, p. 28) labels such acts of unwanted sexual contact as 'opportunistic predation', referring to the fact that the assailant takes advantage of a complex situation, typically a crowded dance floor. In these situations, unlike the situations he labels 'competing definitions', no prior personal interaction has taken place between victim and assailant. Hence, while people may acknowledge this form of unwanted touching as a possibility or risk, they are perplexing when they happen. One might wonder whether these incidents are performative, since they happen when other 


\section{Kari Stefansen}

people are present, but the fleeting and in-passing nature of the incidents suggests otherwise. As Kavanaugh (2013) has described, girls will often not know who the assailant was because the touching happened in a crowd, with the actual act hidden from view. Rather than being performative - a display of sexualised masculinity aimed at an audience - such incidents could be interpreted as spurred by (and with the potential of adding to) the sexualised atmosphere and liminal quality of a party or club. The situational backdrop in this case is hence the flow of meaning that defines such spaces, and not a prior exchange of signals between individuals.

While incidents of opportunistic predation are unwanted and in some cases frightening for the girl, they are different from a third form of unwanted touching that I label aggressive touching. These are acts where the boy takes advantage of a girl while she is sleeping or heavily intoxicated, or where the boy uses physical force or other forms of coercion and constraint, such as by locking her in a room or car. Incidents where the boy had followed the girl - i.e. persistently stalked her - for a whole evening are also included in this category. Such incidents often involve what Stang Dahl (1994) refers to as 'series of acts of force'. 2 This category of acts challenges the idea of unwanted touching as being minor events and underlines the importance of looking at the interaction involved in order to understand how unwanted touching comes about in different situations.

Aggressive touching from friends and acquaintances happened in a range of contexts - at parties and after-parties, in cars, outdoors and at home or at a friend's house. Most of the incidents took place in a private space or away from other youths.

I was held hard and not allowed to go home; he touched me.

[I] was taken advantage of the first time I drank alcohol, by the boy next door. He locked us in a restroom.

The boy was stalking me the whole evening; we were sitting with others, but he still tried to touch my breasts and kiss me, even after I pushed him away.

He was suddenly on top of me [and] pressed me down against the floor. I could hardly move; he made me touch him and masturbate him against my will. He knew it was against my will.

Some of the descriptions illustrate how unwanted touching can shift from being explorative to becoming aggressive, thus illustrating the point about the fluidity of the phenomenon described above. The quote below is an apt illustration:

We sat next to each other, relaxing. He liked me and wanted to touch me. He tried, but he took no for an answer. Eventually.

The word 'eventually' in the quote above suggests that the boy ignored her first 'no' or rejection. This situation had thus seemingly started out as a form of invitation but then developed into a more insistent and aggressive approach. These situations 
may be understood as being linked to the same heterosexual 'hooking-up' logic as explorative touching, which underlines the boy's responsibility to make the first move. The difference in this case is that he ignores her initial rejection and continues to touch her, which also means that these situations are different from the 'competing definitions of the situation' scenarios that Kavanaugh (2013) describes. Like attacks on drunk and sleeping girls, these incidents could be interpreted as displays of male entitlement. The same would be the case for other incidents of aggressive touching that take the form of 'blitz' attacks - sudden and violent and seemingly random.

Very few descriptions of unwanted sexual touching from boyfriends appeared in the material; among the ten descriptions, all could be labelled as aggressive touching. Four descriptions were related to situations where the girl was young - 13 or 14 years old. In two of these cases, the boy was equally young, while in the other two cases, the boy was three to four years older. A commonality seems to be that he wanted her to engage in a sexual activity that she felt she was not ready for - either because of her age or because the relationship was very new. He either applied pressure or force or took advantage of her being younger and more vulnerable.

My boyfriend touched my breasts and down there; I didn't want to, but I didn't dare say anything.

Girl 13, boy 17

He forced me to masturbate him, and he touched my upper body. He locked me in because he wanted to finger me. This happened twice, but I kicked him in the groin. Everything happened at practice: either in the boys' locker room or in the back room.

Girl 13, boy 16

He absolutely wanted to do something sexual with me. I didn't want to, because it was too early [in the relationship]. We'd been together a week. It ended with me masturbating him, and then he was angry because I didn't want to do anything more.

Both 14

The other incidents involved sexual touching after the girl had explicitly said no, or she woke up being touched.

He touched me even if I said no.

I woke up because my boyfriend was fingering me. Earlier that evening, I'd made it clear that I didn't want to have sex.

Given the few descriptions, we cannot draw clear conclusions from this material. Still, it seems reasonable to hypothesise that unwanted sexual touching within teenage romantic relationships is primarily a risk for young girls who, because of their age, are less experienced sexually than their partners. Such touching is also indicative 


\section{Kari Stefansen}

of how very young boys may act out a form of male entitlement to sex in romantic relationships. In some cases, the touching is also facilitated by acts of force.

\section{Situations involving strangers}

In the descriptions involving strangers, performative touching as described above was not common. Descriptions of unwanted sexual touching in public or semi-public spaces were mentioned, but they were of a different quality. These descriptions portrayed behaviour that was unlikely to produce acclaim from peers or any other audience, because it deviated too much from the standard script for sexual or romantic advances. They had a bizarre quality and had associations with something out of control akin to episodic madness, sometimes related to intoxication, as illustrated below:

I was at a party; someone came up to me and started to talk. Then he took his clothes off. I ran away terrified and said I had a boyfriend. Then he put a stranglehold on my boyfriend. I and a few others managed to pull him away, and I cried for a long time. We went home right after.

I was sitting on a bench; someone I didn't know moved closer and closer to me without me noticing before he started to touch me. I ran away, and he didn't follow.

He pursued me on my way home from practice and exposed himself twice on the road, and he wanted me to touch him. He touched my breasts and put his finger against my bum. He was reported to the police and was given a fine.

Public touching from strangers also happens in covert ways: for instance, in a crowd of people. In these situations, the others present are not positioned as an audience, as in performative touching, but represent a facilitating context, as shown in the following quotes:

It happened on the bus when it was crowded, and it happened naturally that people bumped into each other. After a while I realised that someone had touched my bum and that it wasn't an accident. I tried to move but couldn't get away. I heard later that it was a group that did this systematically.

We were at a concert, my friends and I. When we were standing in the middle of a crowd of people, I felt a hand stroking me from the front and back between my legs. I turned around, and a boy was standing there grinning. I asked him, 'What the fuck are you doing?' I slapped him and walked away.

He started to touch me when I was standing in the streetcar. I screamed and hit him, and he left. 
[He was] just someone who passed me and put his hand between my legs and tried to touch me, but he walked away so that no one could see what he'd done. I felt nauseous and lost, but I didn't do anything about it.

These forms of public touching do not seem to fit the three initial categories of acts involving friends/acquaintances and boyfriends (performative, explorative and aggressive touching). What they have in common is a total break with the social contract of the situation. They are acts that are 'out of place' and therefore disturbing. The first cluster of acts are clearly deviant and outside the normal. The second cluster is associated with immature forms of rule-breaking behaviour, sexualised pranks or stunts with a sexual content. The notion of 'opportunistic predation' developed by Kavanaugh (2013) is perhaps relevant; they could also be labelled as 'random predation' - the affected girls just happened to be there when the impulse to reach out occurred. In this sense, these acts could be thought of as a gendered parallel to what has been called meaningless or 'blind' violence between men, typically in urban areas and late at night and committed for no apparent reason. Following this idea, we could consider these random acts of unwanted touching as a form of 'blind sexual violence': blind in the sense that they neither follow from any prior personal interaction nor are sparked by any social energy or shared definition of the situation.

In addition to these disturbing and apparently random forms of unwanted touching, girls described unwanted touching from strangers at pubs, clubs, parties and other social-drinking arenas. These incidents resemble the incidents involving friends and acquaintances from the same social contexts. They seem to be related to displaying or living up to a sexually charged party atmosphere, which I infer from the difference in reactions to the same type of in-passing sexualised touching within other types of public arenas, described above. In these situations, the girls reacted by screaming, slapping the offender or by feeling nauseous and lost. In comparison, girls could describe inpassing sexual touching at nightclubs and parties as 'a minor thing', 'nothing severe' and 'not serious'. One possibility is that in these situations, the girls did not want to be touched - in the sense that they did not want to be touched by a specific person - but they also acknowledged that the touching had been spurred on by the general atmosphere and that they added to the general sexual vibe of the situation. Hence, the girls could think of these acts as being objectifying in a positive sense.

It was nothing severe - just a club where boys are a bit eager to touch you.

Boys who are the grabby type at clubs, but nothing serious.

Me and my friends were out on the town, dancing. We [often] dance with others we meet and with each other, and some of the boys and men out there are a bit creepy. [The girl used a Norwegian term for men who touch women in a sexual way without their permission: 'klåfingret'.] 


\section{Kari Stefansen}

In his discussion of the literature on the affective dimensions of nightlife, Tutenges (2012, p. 133) points to how such environments 'may be understood as force fields of emotional energy where individuals can be assisted in the difficult task of transgressing the confines of their ordinary selves and becoming more wild and adventurous' (see also Pedersen, Tutenges, \& Sandberg, 2017; Tutenges, 2013). Drawing on Williams (2008), Fileborn (2016, p. 18) contends that 'the un-known nature of night-time spaces ... give[s] rise to the possibility of experiences that are not available in day-time spaces'; according to Williams (2008, p. 519), 'the potential for "non-normalised" behaviours' are therefore present. Fileborn (2016, p. 36) uses the word 'downplaying' for situations where her interviewees talked about incidents of unwanted sexual attention in such situations as being 'harmless', or when they described themselves as being able to handle the unwanted attention. An alternative interpretation - one that does not exclude Fileborn's interpretation - is that these incidents are at the same time part of what makes spaces sexually laden and dangerous in the positive sense. Rather than treating them as serious transgressions that are downplayed, this perspective highlights how the situations are open to alternative interpretations and hence may be experienced as being less intrusive. The premise is that incidents that are linked to the underlying social contract - even if they represent transgressions - are less disturbing than incidents that more clearly are out of sync with this contract.

At the same time, a form of ambivalence exists related to incidents like those portrayed above. They are not very severe incidents, and they seem to be part of the normal flow of interaction or meaning - but the line between acknowledging/positive objectifying touching and degrading/objectifying touching is very fine. In some situations, this type of touching is more problematic and is felt as a clear invasion of one's private space.

[I] was out dancing at a club when a boy came over to dance. After a while, he put his hands on my boobs. I removed his hands and told him off. He was offended and left.

I was at a club when this guy came over and put his arms around me from behind outside of my sweater and touched my boobs. He was thrown out of the club later.

It was at a party. Everybody was really drunk. [I'd] flirted a little but didn't mean anything serious. He started to be way too intense and touched me uncomfortably. A male friend 'saved' me.

The last quote above also illustrates how a situation involving a stranger can shift from one mode to the other - from an explorative interaction to the crossing of boundaries and changing of the atmosphere. 


\section{Conclusion}

Mindful that my analysis is based on empirical material that is limited in terms of depth and context, I have described and conceptualised distinct forms of unwanted touching that are distinguishable by their socio-spatial dynamics. As Fileborn (2016, p. 5) has noted, I have also explored experiences that "sit "on the margins" of our current understanding of sexual violence' - the implication being that unwanted sexual attention, and touching, only sometimes fall within our concept of sexual violence. In the following, I discuss how we can meaningfully differentiate between the two situations: those that fall within the concept of sexual violence that has guided my analysis, and those that do not. To that end, I apply Cahill's sexual-ethics framework $(2014,2016)$. Her idea, as outlined in the introduction to this chapter, is that for an act to qualify as sexual violence, it must represent a nullification of the victim's agency or interest in the situation. This means that situations that grant the victim some form of leeway or agency fall short of sexual violence. If the victim's agency nevertheless is compromised, then such situations are unethical and often problematic (and in some cases traumatic), but they do not constitute sexual violence.

How can we then understand the different forms of unwanted sexual touching that girls experience if we read them through this particular lens? Two of the situations seem rather clear-cut in terms of the leeway allowed for the affected girl: unwanted touching from friends and acquaintances at school (performative touching) and public unwanted touching from strangers in non-sexualised spaces (random predation). In these situations, the sexual act is meant for the thrill or amusement of the collective of spectators or the individual assailant; it is not an act that follows from a prior or ongoing interaction between the girl and the assailant. The level of reciprocity in the interaction is low or non-existent. The act is unrelated to her interest in the situation: what she says or does has no implication in the situation. Her presence is that of an object; it is not a social presence. The act therefore represents sexual violence.

The same is the case for the aggressive sexual touching that happens both within teenage romantic relationships and other social relations. These situations portray nullification of her agency: in a sense, he has performed the sexual or sexualised acts on her (Hansen, 2018). Hence, her interest in the situation of not engaging with him at all or in a specific way is not allowed to influence his acts. In these situations, acts of unwanted sexual touching 'fixate a gendered and embodied experience' (Gottzén, 2018, p. 116) on the part of the victim and hence represent a complete closure of the potentiality for rejection and control that the idea of gender freedom (Stang Dahl, 1994) presupposes.

For the three remaining situations - explorative touching from friends/acquaintances that signals romantic or sexual interest, and in-passing touching by both friends/acquaintances, and strangers in party and club settings - the picture is less clear-cut. These situations are linked to more or less sexualised spaces, i.e. spaces with an affective atmosphere that suggests that they are places for sexual advances and possibly contact. For the first type of touching (the making-a-pass type of touching), her reaction and his ensuing response of retreat - the instant backing off - demonstrate that she has agency in the situation and that it is put to productive 


\section{2}

Kari Stefansen

use: he quickly changes his behaviour. Hence, such situations fall short of the definition of sexual violence as the eradication of self-determination or loss of control relating to sex and sexual encounters and relations. Because such incidents happen in public or semi-public places, they could also be interpreted as having a performative dimension. What separates these incidents from clear cases of performative touching is, as described above, the leeway for her agency or will.

For the latter types of unwanted touching - the types that happen on the dance floor, or in other spaces within drinking venues or parties - the question of the scope of the affected girl's interest or will is more complicated. If her interest or will is related to becoming absorbed in the sexualised atmosphere, then his transgression in a sense is in line with her interest. Her reaction - as well as her classification of the incident as unwanted sexual touching - indicates that this is not the whole story; that his actions do not totally align with her interest but are off-balance or badly timed. I take a cue in this case from Heinskou (2010), who refers to discomfort and unease in sexual or sexualised situations as being related to shifts in temporality: 'the rhythm of the social relation has perhaps jumped a step or a heartbeat, and this can be experienced as a physical form of discomfort' (p. 141). Hence, discomfort may relate not so much to the sexualised act itself but to a lack of synchronisation.

Demant and Heinskou (2011) offer an interesting perspective on transgressions in sexualised party settings. They argue that in order to understand sexual assault among young people, the standard risk perspective should be combined with a perspective on chance: 'analytically, it is suggested that young men and women go to parties and drink in an attempt to take a chance, but the chance, in some cases, backfires' (p. 398; italics in the original). This interpretation is related to the fact that parties also are gendered contexts, with social norms that affect young girls' and boys' sexual expressions and ability to resist sexual advances. Because the 'backfiring' in this case only represents a partial break of the flow of meaning in the situation - i.e. to experience what Demant and Heinskou (2011), drawing on Vance (1984), refer to as the 'pleasures of the dangers' of drinking and partying in my interpretation, the act rests within the realm of the unethical but does not by default cross the border into sexual violence. The premise is that situations of asynchronicity in interests are different from situations totally dominated by the interest of one party in the interaction. As described earlier, in-passing touching in party contexts can also represent cases of opportunistic predation. In these situations the girl's will is undermined in a different way - the touching more clearly demonstrates the domination of the boy's will over hers; the danger involved in touching a more or less random person adds to his thrill only, not hers.

What further complicates the understanding of unwanted sexual touching is the way in which acts that remain outside the boundary of sexual violence work on the cultural or symbolic level, what Fileborn $(2016$, p. 6) calls the 'background' experiences of sexualised violence. Cahill (2001) makes a similar point. She writes about how her knowledge of girls' vulnerability to sexual violence and of her female friends' experiences combine to affect her own self-understanding as being 'rapeable' and therefore as someone who must be careful: 'the possibility of rape shapes the space I inhabit' (p. 1). 
My point is that the minor transgressions that do not cross the boundary of sexual violence also feed into the 'phenomenology of fear' among girls and women that Cahill (2001, p. 143) describes. In this sense, unethical sexual acts are far from innocent or 'minor'. As Stefansen et al. (2014) have commented, such incidents may work as a form of implied gendered violence (cf. Sheffield, 1987) that affects girls in general. Cornell's $(1995,2007)$ notion of the 'imaginary domain' is helpful to explain this point. The imaginary domain is the psychic space that allows people the freedom to think about who they want to be as sexuate and sexual beings. The micro-transgressions that girls encounter on a regular basis shrink this space for girls and women in general. They work as constant reminders that girls must take into account that their right to bodily integrity is less protected than it is for boys. Such acts may therefore spur girls to adjust what their interest in a situation can be: to the possibility of sexual assault. Some girls, for example, may refrain from engaging in the sexualised energy of party and night-time spaces, which not only deprives them of the possibility for positive transgressions - of letting go of their controlled, everyday selves (Tutenges, 2012) - but may also leave them more vulnerable to experiencing sexual violence. Those absorbed in the party vibe may feel or treat micro-transgressions on the dance floor or at the bar as minor; for those who are not, the same acts are more likely to be experienced as a violent attack that demands a response, such as anger, disgust, shame or fear. Hence, what is intended as protective or preventive behaviour may paradoxically become a risk factor.

\section{Acknowledgements}

This chapter was written as part the Domestic Violence Research Programme at Oslo Metropolitan University, funded by the Norwegian Ministry of Justice and Public Security. The author would like to extend a warm thanks to Marie Heinskou, MayLen Skilbrei and Ingrid Smette for their valuable comments on earlier versions of the chapter.

\section{Notes}

1 As Patosalmi (2009) has discussed, Cornell's (2007) theory of the imaginary domain is complex and is founded on ideas of subjectivity and the person from psychoanalytic thinking. In this chapter, I use the notion of the imaginary domain as a metaphor in order to draw our attention to the collective or systemic aspect of sexual violence.

2 In Norwegian: 'Serier av tvangshandlinger'.

\section{References}

Bakken, A. (2017). Ungdata: Nasjonale resultater 2017. Oslo: NOVA.

Bjørnholt, M., \& Helseth, H. (2019). 'Jeg ville jo bare si nei' - Seksuell vold i parforhold. In K. Skjørten, E. Bakketeig, M. Bjørnholt, \& S. Mossige (Eds.), pp. 85-103. Vold i ncere relasjoner: Forståelser, konsekvenser og tiltak. Oslo: Universitetsforlaget.

Cahill, A. J. (2001). Rethinking rape. Ithaca, NY: Cornell University Press. 


\section{Kari Stefansen}

Cahill, A. J. (2014). Recognition, desire, and unjust sex. Hypatia, 29(2), 303-319.

Cahill, A. J. (2016). Unjust sex vs. rape. Hypatia, 31(4), 746-761.

Collins, R. (2009). Violence: A micro-sociological theory. Princeton, NJ: Princeton University Press.

Cornell, D. (1995). The imaginary domain: Abortion, pornography and sexual harassment. New York: Routledge.

Cornell, D. (2007). The shadow of heterosexuality. Hypatia, 22(1), 229-242.

Demant, J., \& Heinskou, M. B. (2011). Taking a chance: Sex, alcohol and acquaintance rape. Young, 19(4), 397-415.

Fileborn, B. (2016). Reclaiming the night-time economy: Unwanted sexual attention in pubs and clubs. London: Palgrave Macmillan.

Gillander Gådin, K., \& Stein, N. (2017). Do schools normalise sexual harassment? An analysis of a legal case regarding sexual harassment in a Swedish high school. Gender and Education, 1-18. doi: 10.1080/09540253.2017.1396292

Gottzén, L. (2018). Geographies of anger and fear: Exploring the affective atmospheres of men's 'domestic' violence. In M. Livholts \& L. Bryant (Eds.), Social work in a glocalised world (pp. 106-118). London: Routledge.

Graham, K., Bernards, S., Abbey, A., Dumas, T. M., \& Wells, S. (2017). When women do not want it: Young female bargoers' experiences with and responses to sexual harassment in social drinking contexts. Violence against Women, 23(12), 1419-1441.

Hansen, M. L. J. (2018). Vilje og motvilje: Fortellinger bak ikke-anmeldte voldtekter. (MA thesis in criminology). Oslo: University of Oslo.

Heinskou, M. B. (2010). En kompleks affare: Anmeldte voldtogter i Danmark. $\mathrm{PhD}$ dissertation. Copenhagen: Copenhagen University.

Kahn, A. S. (2004). 2003 Carolyn Sherif award address: What college women do and do not experience as rape. Psychology of Women Quarterly, 28(1), 9-15.

Kahn, A. S., Jackson, J., Kully, C., Badger, K., \& Halvorsen, J. (2003). Calling it rape: Differences in experiences of women who do or do not label their sexual assault as rape. Psychology of Women Quarterly, 27(3), 233-242.

Kavanaugh, P. R. (2013). The continuum of sexual violence: Women's accounts of victimization in urban nightlife. Feminist Criminology, 8(1), 20-39.

Kelly, L. (1988). Surviving sexual violence. Cambridge, UK: Polity Press.

Khan, S. R., Hirsch, J. S., Wambold, A., \& Mellins, C. A. (2018). 'I didn't want to be "that girl"': The social risks of labeling, telling, and reporting sexual assault. Sociological Science, $5,432-460$.

Krange, O., \& Pedersen, W. (1999). Å angre på sex. Sosiologisk tidsskrift, 7(1), 45-70.

Lahelma, E. (2002). Gendered conflicts in secondary school: Fun or enactment of power? Gender and Education, 14(3), 295-306.

LeMaire, K. L., Oswald, D. L., \& Russell, B. L. (2016). Labeling sexual victimization experiences: The role of sexism, rape myth acceptance, and tolerance for sexual harassment. Violence and Victims, 31(2), 332.

McGlynn, C., \& Munro, V. E. (Eds.). (2010). Rethinking rape law: International and comparative perspectives. London: Routledge.

Megarry, J. (2014). Online incivility or sexual harassment? Conceptualising women's experiences in the digital age. Women's Studies International Forum, 47(Part A), 46-55.

Mossige, S., \& Stefansen, K. (2007). Vold og overgrep mot barn og unge: En selvrapporteringsstudie blant avgangselever $i$ videregående skole. Oslo: NOVA. 
Mossige, S., \& Stefansen, K. (2016). Vold og overgrep mot barn og unge: Omfang og utviklingstrekk 2007-2015. Oslo: NOVA.

Munro, V. E. (2010). From consent to coercion: Evaluating international and domestic frameworks for the criminalization of rape. In C. McGlynn \& V. E. Munro (Eds.), Rethinking rape law (pp. 17-29). Oxfordshire, UK: Routledge.

Patosalmi, M. (2009). Bodily integrity and conceptions of subjectivity. Hypatia, 24(2), 125-141.

Pedersen, W., Tutenges, S., \& Sandberg, S. (2017). The pleasures of drunken one-night stands: Assemblage theory and narrative environments. International Journal of Drug Policy, 49, 160-167.

Robinson, K. H. (2005). Reinforcing hegemonic masculinities through sexual harassment: Issues of identity, power and popularity in secondary schools. Gender and Education, 17 (1), 19-37.

Sheffield, C. J. (1987). Sexual terrorism: The control of women. In B. B. Hess \& M. M. Ferree (Eds.), Analyzing gender: A handbook of social science research (pp. 171-189). Newbury Park, CA: Sage.

Skilbrei, M.-L., \& Stefansen, K. (2018). Seksuell vold: En samfunnsvitenskapelig innføring. Oslo: Cappelen Damm Akademisk.

Smart, C. (1995). Law, crime and sexuality: Essays in feminism. London: Sage.

Stang Dahl, T. (1994). Pene piker haiker ikke. Oslo: Universitetsforlaget.

Stefansen, K., Överlien, C., \& Frøyland, L. (in preparation). Exploring gendered aspects of incapacitated sexual assaults among teenagers.

Stefansen, K., \& Smette, I. (2006). Det var ikke en voldtekt, mer et overgrep: Kvinners fortolkninger av seksuelle overgrepserfaringer. Tidsskrift for samfunnsforskning, 47(1), 33-56.

Stefansen, K., Smette, I., \& Bossy, D. (2014). Angrep mot kjønnsfriheten: Unge jenters erfaringer med uønsket beføling. Tidsskrift for kjønnsforskning, 38(1), 3-19.

Thompson, L. (2018). 'I can be your Tinder nightmare': Harassment and misogyny in the online sexual marketplace. Feminism \& Psychology, 28(1), 69-89.

Tinkler, J. E., Becker, S., \& Clayton, K. A. (2018). 'Kind of natural, kind of wrong': Young people's beliefs about the morality, legality, and normalcy of sexual aggression in public drinking settings. Law \& Social Inquiry, 43(1), 28-57.

Tutenges, S. (2012). Nightlife tourism: A mixed methods study of young tourists at an international nightlife resort. Tourist Studies, 12(2), 131-150.

Tutenges, S. (2013). Stirring up effervescence: An ethnographic study of youth at a nightlife resort. Leisure Studies, 32(3), 233-248.

Vance, C. S. (1984). Pleasure and danger: Toward a politics of sexuality. In C. S. Vance (Ed.), Pleasure and danger: Exploring female sexuality (pp. 1-27). Boston, London, Melbourne, and Henley, UK: Routledge \& Kegan Paul.

Vera-Gray, F. (2016). Men's stranger intrusions: Rethinking street harassment. Women's Studies International Forum, 58(September-October), 9-17.

Williams, R. (2008). Night spaces: Darkness, deterritorialization, and social control. Space and Culture, 11(4), 514-532. 


\title{
5 Making the case for ' $g o o d$ enough' rape-prevalence estimates
}

\author{
Insights from a school-based survey \\ experiment among Norwegian youths
}

\author{
Kari Stefansen, Mette Løvgren and \\ Lars Roar Frøyland
}

\section{Introduction}

How to measure rape precisely has been a key topic in feminist research on violence against women since the 1980s. The issue of rape estimates is currently high on the agenda among jurisdictions that seek to develop prevention policies towards rape and other forms of sexual violence - such as Norway, the empirical context of this chapter. In national policy documents, prevalence estimates are held to be important because they shed light on the 'dark figure' of rape, i.e. the gap between incidents reported to the police and the real scope of the problem (e.g. Ministry of Justice and Public Security, 2012). States' responsibilities to monitor the prevalence of rape are also incorporated in supranational policies, such as the 2011 Council of Europe Convention on preventing and combating violence against women and domestic violence (known as the Istanbul Convention), which all the Nordic countries have ratified.

In Norway, the study of rape prevalence is still in the early stages. In 2008, when the first governmental committee was appointed to outline new directions for rape prevention (Ministry of Justice and Public Security, 2008), no nationally representative surveys were available. The committee therefore estimated the national prevalence based on a survey conducted in Oslo, the capital city (Pape \& Stefansen, 2004). The prevalence from Oslo is not necessarily representative for the whole country, however, due to the city's significantly higher proportion of inhabitants from migration backgrounds and a larger dispersion of economic and cultural resources than is the case among the general Norwegian population.

Since 2010, two studies have been conducted on nationally representative samples of the adult population (Steine, Milde, Bjorvatn, Grønli, \& Nordhus, 2012; Thoresen \& Hjemdal, 2014). Both departed from the legal definition of rape and used behaviourally specific questions to measure the prevalence of acts that fall within this definition. Norwegian law defines rape as an act of penetration by the use of force or threats, as well as sexual assault against a person who is unable to consent (penal code section 191; see Skilbrei \& Stefansen, 2018). The definition further includes incidents where direct contact has occurred between the sex organ 
or finger of the accused (or an object or someone acting on the accused's behalf) and the victim's vagina or anus, as well as the insertion of a penis into the victim's mouth (Haugen \& Efjestad, 2015, p. 344). The code also extends to incidents involving masturbation. The threshold for what counts as force is generally considered very low and is in line with legislation elsewhere with a focus on non-consent (Ot. prp. nr. 22 [2008-2009]).

The two studies mentioned above had different samples and used different methodologies, but they reported similar rates of rape prevalence. One study (Steine et al., 2012) used a six-item measure that included incapacitated sexual assault and the experience of feeling pressured to have intercourse without the use of threats or force, as well as forced or threatened penetration of bodily orifices by a sex organ, finger or object. In comparison, Thoresen and Hjemdal (2014) used a four-item measure covering different forms of penetration by the use of force or threats (against the victim or someone close to the victim), and they did not ask about pressure (which in most cases would not qualify as rape in the legal sense). They also excluded an item on incapacitated sexual assault. Steine et al. (2012) reported a total prevalence of rape experiences after the age of 16 to be $16.3 \%$ for women and $1.6 \%$ for men. The item on pressure revealed the highest number by far for women: $11.6 \%$ had experienced being pressured to have intercourse. For the other items, the numbers varied from $1.6 \%$ to $4.1 \%$ (see Steine et al., 2012, Table 5.3, p. 954). Thoresen and Hjemdal (2014) reported somewhat lower lifetime rates for rape: $9.4 \%$ for women and $1.1 \%$ for men.

Although very similar in their results, the two studies illustrate a general point: that to measure rape is also to construct rape. What we include and what we exclude speaks to and contributes to specific understandings of a given phenomenon. While this might be a rather banal insight, it is a fundamental one if we are to construct reliable measures of the prevalence of rape across time and context.

Given this background, the aim of this chapter is twofold: first, to introduce ongoing discussions about rape measurement in the international literature, and second, to present and discuss results from a large-scale school-based survey among Norwegian youth that featured an experiment in which two different rape measures were presented to the participants. We ask: What can we learn from comparing the two measures, and how can we assess the quality of the 'better' measure? In what sense is it 'good enough' as a prevalence measure?

\section{Rape measurement: the international debate}

The development of methodology for the measurement of rape is intimately connected to the 1980s work of the US psychologist Mary P. Koss in developing the Sexual Experiences Survey (SES), a set of behaviourally specific questions about rape and other forms of sexual assault that were first published in Koss and Oros (1982) and later revised in Koss, Abbey, Campbell, Cook, and Norris (2007). The original aim of the SES was to capture all acts that had been criminalised as rape. It therefore included both less violent attacks and 
rape in intimate relationships, such as date rape and marital rape. During the eighties and nineties, studies based on the SES found rape and other forms of sexual assault to be much more prevalent than estimates from general crime surveys and police statistics had indicated (Koss, 1992, 1993; Koss, Gidycz, \& Wisniewski, 1987). These studies were also the subject of criticism, however. Gilbert (1993), for example, argued that their definition of rape was too broad and that the questions that were posed captured incidents that did not meet the legal criteria for rape. In essence, Gilbert critiqued Koss and the SES for casting the net too wide.

In a comprehensive report about rape measurement, Fisher and Cullen (2000) described the situation at the end of the 1990s as being characterised by controversy. Their report, which reviewed research to date on rape measurement and aimed to outline directions for future research, then sparked new debates. Fisher and Cullen followed Koss in the rejection of stand-alone questions that ask directly about exposure to rape, forced intercourse or similar formulations. Such questions cast the net too narrowly and have poor validity, because most respondents will respond in accordance with stereotypical ideas about rape. The result, most often, is massive underreporting of rape, especially of rapes committed by partners and acquaintances and of date rape (Kahn, 2004; Kahn, Jackson, Kully, Badger, \& Halvorsen, 2003; Stefansen \& Smette, 2006).

Fisher and Cullen (2000) acknowledged Koss and colleagues' important contributions to rape measurement, especially the shift from general to behaviourally specific questions. The latter approach offers a way around cultural beliefs about rape and rapists because it focusses on specific acts - which researchers can then calculate into rape measures - although they also criticised the one-step model that the SES represents. Fisher and Cullen's reservation was that not all the recorded incidents would likely meet the legal criteria of rape had the researchers followed up with more detailed questions. Hence, the one step-model may lead to exaggerated estimates of rape. As the authors argue,

the risk of this one-step approach - that is, of not having an incident report is that it may include reports of victimization that, on closer scrutiny, would not qualify legally as a rape or other types of sexual victimization.

(Fisher \& Cullen, 2000, p. 324)

They instead argue that a two-step model would yield more accurate estimates. In this model, the respondents are first presented with a list of screening questions about different forms of sexual assault that are intended to trigger the respondents' memory about relevant incidents. Respondents who answer yes to one or more of the first set of questions are then asked a new set of questions related to each incident. Prevalence estimates are based on the information from the second step and will only include incidents that meet the legal criteria for rape. According to Fisher (2009), this model ensures both that incidents that are mistakenly included in the material as rape through the first step can be excluded and that other forms of sexual assault can be reclassified as rape through the second 
step and subsequently used in the prevalence estimate. Hence, the model solves two problems: it avoids both casting the net too wide (by excluding 'false' rapes) and casting it too narrowly (by including 'false' non-rapes).

Fisher (2009) has further shown that asking more questions and using behaviourally descriptive questions in the first step includes a higher number of respondents in the incident report and yields a higher percentage of rape victims in the second step. Koss and colleagues (in Cook, Gidycz, Koss, \& Murphy, 2011) have responded to Fisher and Cullen's (2000) critique and the two-step model's potential for more accurate measurements. They contend that it is ethically problematic to exclude respondents who have indicated that they have been raped, even if they respond differently later in the questionnaire. They refer to the two-step method Fisher (2009) used as 'confrontational' (p. 210) because the interviewer asks the respondent about what 'actually' happened during the reported incident. This critique is a reminder that concerns other than accuracy - such as the potential for psychological distress - must be taken into account when assessing the usefulness of rape-measurement models.

\section{A pragmatic approach to rape measurement}

While these authors disagree on the merits of the two-step model compared to the one-step model, what they have in common is a commitment to work towards establishing best practice for rape-measurement research. These methodological debates may give the impression that it is possible to design an instrument that will capture all incidents of rape in a surveyed sample. Fisher and Cullen, however, comments that researchers now acknowledge that it unlikely that any model can avoid all sources of error:

In particular, researchers have come to realize that conceptually defining and then operationalizing sexual victimization are complicated and, to a degree, imperfect enterprises - especially when deciding when an unwanted sexual advance crosses the line from imprudence to criminal behaviour.

(Fisher \& Cullen, 2000, p. 320)

Fisher and Cullen (2000) also stress that the issues of definitions and operationalisations of rape and other forms of sexual violence are epistemological, since 'they raise critical issues about what we know and how we know it' (p. 340).

In a review article, Krebs (2014) summarised the debate on rape measures and argued for a pragmatic approach. The key issue, according to the author, is to understand when different models are suitable and how they can be improved. In his view, it is more fruitful to establish consensus on areas that different models have in common rather than to continue debating which model is best. This consensus would include the fact that instruments that use behaviourally specific questions within self-administrating surveys seem to work well. 


\section{Kari Stefansen et al.}

His approach, which we follow here, represents a call for establishing consensus on 'good enough' instruments. In our opinion, doing so does not necessarily conflict with a quest for better or ideal instruments for population estimates of rape but represents a complementary approach. In the next section, we describe the study that our analyses are based on.

\section{The study}

\section{Sample and participants}

Our data are drawn from a school-based study among students aged 18-20 years in Norway in the last year of upper secondary school. The data were collected in 2015. The students answered a comprehensive electronic questionnaire about different types of victimisation, including questions about sexual assault and rape. The study was a follow-up to a similar study conducted in 2007 (Mossige \& Stefansen, 2007) and therefore used the same sample of schools. For the 2007 study, a representative sample of schools was provided by Statistics Norway following a two-stage procedure. The schools were first allocated to five geographical regions to ensure participation from the whole country and then stratified within each region into three categories: vocational track only, academic track only and combined. The 67 participating schools were then selected to ensure proportional allocation. These schools were contacted again and asked to participate in the 2015 study. A total of 41 schools from the 2007 study participated; in addition, eight replacement schools were selected to fit the relevant strata, yielding a total sample of 49 schools. From these schools, 4,530 students participated, resulting in a response rate of $66.2 \%$. Schools and groups within schools with a response rate below $10 \%$ were excluded from the material. In these cases, the survey had not been administered according to instructions.

The students completed the survey during two consecutive school sessions with a teacher present in the classroom. The mean age of the respondents was 18.4 years; 1,766 respondents were male, and 2,580 were female. The gender difference in the sample was caused by a larger proportion of academic-track schools (in which girls are overrepresented). The gender was missing for 65 respondents. The analyses discussed in this chapter are restricted to students between 18 and 20 years old with non-missing responses to the question of gender. For the rape items, we included students with non-missing responses on at least one item of the multi-item measure (described below). The final sample for the analyses presented in this chapter consisted of 4,346 participants.

Because we recruited respondents through schools, dropouts were not part of the sample, which may have affected the results - those who drop out differ from those who do not in terms of risk and protective factors associated with rape (Mossige \& Stefansen, 2007, 2016). 


\section{Questions and variables}

The items about rape were part of a survey instrument in which a range of sexual-victimisation experiences were mapped, including unwanted touching and attempted rape. Those items that were designed to capture experiences with rape followed items about other forms of sexual victimisation. The latter items could therefore work as memory cues for unwanted sexual experiences, including rape.

Using a survey-experiment design, we randomly assigned the respondents to different versions of the instrument: one with a single question about rape and the other with five behaviourally specific items. In the questionnaire, both versions had the following introductory phrase: Before/after the age of 13, have you been subjected to any of the following against your will? Alternative 1 read: 'You have been raped'. Alternative 2 consisted of the following items: someone 'forced or threatened you to have intercourse', 'forced or threatened you to have oral sex', 'forced or threatened you to have anal sex', 'injected fingers or objects into your vagina or anus', and 'has had sex with you while you were asleep or too drunk to object'. The answer options for both versions were 'No, never', 'Yes, once', and 'Yes, several times'. As expected, the randomisation achieved balance across variables such as gender, age, parents' socioeconomic status and school track (academic or vocational). Hence, all observed differences in reported prevalence rates are attributable to being asked either broad or behaviourally specific questions (cf. Løvgren, Stefansen, Smette, \& Mossige, 2017).

In the following, we investigate how the behaviourally specific questions compare to the broad one-item question. First, we compare the responses from girls and boys; we then compare the responses between girls within different subgroups to test if different wordings had greater or lesser impact within certain groups compared to others. This part of the study is exploratory, meaning that we do not have existing research on which to form hypotheses on the impact of different wording between subgroups, although we do expect that the behaviourally specific instrument will yield significantly higher prevalence rates compared to the one-item question, and that this result will hold for both genders and across different subsamples. Because the sample size was reduced when we analysed subgroups, the lower prevalence rates of rape experiences among boys compared to girls led to problems with statistical power; therefore, these analyses were only conducted for girls.

We do not distinguish between experiences before and after the age of 13 . Most of the reported experiences of rape took place after the age of 13 (analysis not shown). We used dummy variables in all analyses. For the one-item question (labelled 'Rape1' in this chapter), a value of 1 was given to those who reported having been raped at least once, either before or after the age of 13 . We constructed two different dummy variables based on the five-item alternative, with a value of 1 indicating at least one positive answer. The 'Rape4' measure consists of the four items that specify different forms of penetration 


\section{Kari Stefansen et al.}

with the use of force or threats, excluding the item on incapacitated sexual assault. The 'Rape5' measure includes all five items.

We had two reasons for constructing two variables rather than one. First, we wanted to compare our results with those of another Norwegian study in which incapacitated sexual assault was not included in the reporting of the results (Myhre, Thoresen, \& Hjemdal, 2015). Second, the 'incapacitated sexual assault' item used the general term 'sex' rather than specifying an act of penetration. We address possible implications of this choice of wording in the discussion section below.

In addition to the questions about rape, we use variables on family economy, parents' work-life participation and choice of academic track in upper secondary school in the analyses. Family economy is measured by a single question: 'Over the last two years, has the economic situation of your family been good or bad?' The response options were 'Good all of the time', 'Mostly good', 'Neither good nor bad', 'Mostly bad', and 'Bad all of the time'. The measure was dichotomised into two dummy variables: good economy ('good all of the time' and 'mostly good'), and poor economy ('mostly bad' and 'bad all of the time'). Two variables measure whether the respondents' fathers and mothers were currently working (either full time or part time), and two variables measure if either parent received social benefits. Finally, a single question measures whether the respondents followed the academic or vocational track in upper secondary school. All these variables were coded into dummy variables (1 for affirmative answers; otherwise 0).

We tested for mean differences across groups using $t$-testing. Because we have tested multiple hypotheses and have thus increased the chances of test results displaying as significant when they are in fact not, we advise caution in interpreting the results. Specifically, with a significance level of $p=0.05$, one out of every 20 analyses could, out of statistical necessity, be expected to return a significant result, more commonly known as a false positive finding (type I error).

\section{Results}

As demonstrated in Table 5.1, very few male students reported being subjected to sexual assault, by either measure. The absolute numbers as well as the rates are higher among female students. The differences between males and females are significant for all items except the one on anal penetration. Both for boys and girls, incapacitated sexual assault is the more common experience. Among girls, being subjected to enforced penetration of a finger or object and by a penis are more common than enforced oral and anal penetration. Among boys, about 1\% reported all the different forms of penetration.

Interestingly, among girls, the one-item question about rape and the item on forced or threatened intercourse had very similar rates, only differing by half a percentage point. This finding could suggest that what the subsample which received the one-item measure had reported as rape were incidents of forced or 
Table 5.1 All items. Prevalence of positive responses. By gender. Frequency and percent.

\begin{tabular}{|c|c|c|c|c|c|c|c|}
\hline & \multicolumn{3}{|c|}{ Boys } & \multicolumn{3}{|c|}{ Girls } & \multirow[b]{2}{*}{ T-test p-value } \\
\hline & Percent & Freq. & $N$ & Percent & Freq. & $N$ & \\
\hline \multicolumn{8}{|l|}{ Broad question } \\
\hline $\begin{array}{l}\text { You have been raped } \\
\text { Behaviourally specific questions }\end{array}$ & $s^{1.1}$ & 9 & 832 & 5 & 62 & 1259 & $<0.001$ \\
\hline $\begin{array}{l}\text { Forced or threatened you } \\
\text { to have intercourse }\end{array}$ & 0.9 & 8 & 872 & 4.5 & 57 & 1275 & $<0.001$ \\
\hline $\begin{array}{l}\text { Forced or threatened you } \\
\text { to have oral sex }\end{array}$ & 0.9 & 8 & 873 & 2.9 & 37 & 1271 & $<0.01$ \\
\hline $\begin{array}{l}\text { Forced or threatened you } \\
\text { to have anal sex }\end{array}$ & 0.8 & 7 & 870 & 1.7 & 21 & 1271 & $>0.05$ \\
\hline $\begin{array}{l}\text { Injected fingers or objects into } \\
\text { your vagina or anus }\end{array}$ & 0.9 & 8 & 873 & 6 & 76 & 1273 & $<0.001$ \\
\hline $\begin{array}{l}\text { Someone has had sex with you } \\
\text { while you were asleep } \\
\text { or too drunk to object }\end{array}$ & 2.2 & 19 & 868 & 7.6 & 96 & 1270 & $<0.001$ \\
\hline
\end{tabular}

threatened intercourse. This situation would correspond with the common finding that assaults involving intimidation or the explicit use of physical power more often are considered rape (Ryan, 2011; Stefansen \& Smette, 2006). Because the items were distributed to different subsamples and not the same respondents, we cannot test the degree of overlap.

How do the different measures of rape compare? Table 5.2 shows the results for the dummy variables Rape1, Rape4 and Rape5. Because each variable is a dummy, the mean reads as a percentage; a mean of 0.05 means a $5 \%$ prevalence.

Table 5.2 demonstrates - as expected - that the measures based on behaviourally specific questions elicited higher rates of sexual assault among both boys $(p<0.001)$ and girls $(p<0.001)$. Further, the gender differences are notable. For girls, the prevalence rate increases from $5 \%$ to $14 \%$ from the oneitem to the five-item measure, and for boys, the rate increases from $1 \%$ to $3 \%$. Table 5.2 also demonstrates that the difference in victimisation rates between boys and girls increases as more items are included in the measure. The difference is four percentage points for the one-item question, seven percentage points for the four-item measure and eleven percentage points for the fiveitem measure.

The analyses so far relate to the whole sample. We also investigated if the measures based on the behaviourally specific questions would increase the prevalence of rape to a similar degree within different subgroups of girls. This would strengthen the evidence for the instrument if so. For these analyses, we 
Table 5.2 Three measures of rape. Boys and girls. Between-group mean comparison. $t$-Test.

\begin{tabular}{lllllllll}
\hline & \multicolumn{4}{c}{ Boys } & & \multicolumn{4}{c}{ Girls } \\
\cline { 2 - 4 } & $N$ & Mean & Std. Dev. & $N$ & Mean & Std. Dev & t-Test, p-value \\
\hline Rape1 & 832 & 0.01 & 0.1 & & 1259 & 0.05 & 0.22 & $<0.001$ \\
Rape4 & 872 & 0.02 & 0.12 & & 1276 & 0.09 & 0.29 & $<0.001$ \\
Rape5 & 873 & 0.03 & 0.17 & & 1276 & 0.14 & 0.34 & $<0.001$ \\
\hline
\end{tabular}

chose a set of sociodemographic variables known to affect levels of sexual assault. Research in Norway has consistently shown that the risk of sexual victimisation is significantly higher among those with low socioeconomic status compared to those with high socioeconomic status (Mossige \& Stefansen, 2007, 2016; Pape \& Stefansen, 2004). The same pattern has been documented in international research (e.g. Phipps, 2009). For this study, we use indicators related to family economy, parents' labour-market status and choice of academic track in upper secondary school.

In the following analyses, we focus only on differences between two measures (Rape1 and Rape4) because we are uncertain about the types of experiences reported in the fifth item, on incapacitated sexual assault. The use of the general concept 'sex' in this item means that it is unclear if the reported incidents involved acts that are criminalised as rape in the Norwegian penal code, or if they represent cases of sexual assault that do not involve penetration (or penetration-like acts). We draw on Myhre et al. (2015), who found that around $50 \%$ of reported incidents on a similar item did not involve penetration. In order to ensure internal validity, we therefore proceeded with the four-item measure, given that all the acts covered align with the legal definition of rape (Table 5.3).

The group differences in rape prevalence are large but as expected. For example, the rate of rape is considerably lower among girls with a good family economy in the last two years compared to girls with a poor family economy in the same period. For the Rape 1 measure, the prevalence is $4 \%$ for the former group and $12 \%$ for the latter group; for Rape 4 , the respective numbers are $8 \%$ and $19 \%$. Not surprisingly, we see a nearly identical pattern for girls with parents who work or receive social benefits (variables that are indicative of the economic conditions of the family). We see corresponding but lower differences between the other groups. The difference for Rape1 between girls in academic and non-academic tracks is close to three percentage points, and for Rape4, the difference is around nine percentage points.

For most of the groups included in the study, the prevalence of rape was significantly higher when we used the four-item measure compared to the single-item measure. The non-significant result for having a poor family 
Table 5.3 Rape measures and socio-economic characteristics. Girls. Between-group mean comparison. $t$-Test.

\begin{tabular}{|c|c|c|c|c|c|c|c|}
\hline & \multicolumn{3}{|c|}{ Rape1 } & \multicolumn{3}{|c|}{ Rape4 } & \multirow[b]{2}{*}{ T-test } \\
\hline & $N$ & Mean & St. dev. & $N$ & Mean & St. dev. & \\
\hline Poor family economy & 67 & 0.12 & 0.33 & 58 & 0.19 & 0.4 & n.s. \\
\hline Good family economy & 925 & 0.04 & 0.2 & 953 & 0.08 & 0.27 & $* * *$ \\
\hline Father working & 1058 & 0.043 & 0.20 & 1093 & 0.09 & 0.28 & $* * *$ \\
\hline Father social benefits & 64 & 0.13 & 0.33 & 58 & 0.14 & 0.35 & n.s. \\
\hline Mother working & 1059 & 0.046 & 0.21 & 1081 & 0.088 & 0.28 & $* * *$ \\
\hline Mother social benefits & 91 & 0.044 & 0.21 & 98 & 0.13 & 0.34 & $*$ \\
\hline Academic track & 892 & 0.043 & 0.2 & 940 & 0.076 & 0.26 & $* *$ \\
\hline Non-academic track & 94 & 0.043 & 0.2 & 78 & 0.13 & 0.34 & $*$ \\
\hline
\end{tabular}

economy is most likely ascribable to the low $n$, as the $t$-test is a function of the magnitude of the observed differences and the sample size. In larger groups (e.g., the non-academic-track group), similar differences returned significant results at the 0.05 level. In general, the Rape4 measure resulted in approximately twice the rate of rape compared to the Rape1 measure. Following an academic track resulted in a somewhat smaller discrepancy between the two measures. But logistic regression analyses (not shown), with an interaction term between the different background characteristics and the given rape instrument, showed no significant results. As such, the relative difference in the proportion of rape measured by the two rape instruments does not differ significantly according to background characteristics.

Overall, the measures provide comparable differences in rape rates for all the groups we included, even though the total prevalence varied greatly according to the given instrument and among the different groups. We may thus conclude that the four-item measure works as intended. It captures a significantly higher number of rape experiences across different groups of girls compared to the one-item measure, thereby reducing underreporting. The measure hence provides an estimate of rape that is more in accordance with the penal definition of rape. Does this mean that it can be considered 'good enough'? This would depend on the criteria for defining what is good enough - to be discussed next.

\section{Discussion}

We have shown that the four-item measure works as intended and performs well across different groups. The measure, which is based on recommendations in the international literature, is part of a broader instrument that also surveys other forms of sexual assault (which then triggers participants' memory of unwanted sexual experience), and the items are behaviourally descriptive. The 


\section{Kari Stefansen et al.}

items also cover acts that have been criminalised as rape in the Norwegian penal code. We would add that the measure has important advantages for examining the population in question (students in upper secondary school) and for the chosen methodology (i.e. a more general victimisation survey administered at school).

First, the measure is relatively short, meaning that it can be integrated into surveys on a wider range of topics, including other aspects related to sexual assault such as background characteristics, risk factors and health outcomes. The use of a short instrument also prevents exhaustion on the part of the respondents and subsequently reduces the number of missing answers on later items in the instrument. We found this to be the case in the present study, where $98 \%$ of those who had answered the first question in the instrument also answered the remaining questions. While the length of questionnaires and instruments is important for all samples, it is likely that the length is even more critical when conducting surveys among young people. A related point is that asking less detailed and probing questions may be less emotionally draining for students who have experienced rape - and therefore would be more suitable for use in classroom settings with other students and a teacher present, where an emotional reaction would be noticed.

Second, the items themselves are short and entail few elements; the aim of this approach is to limit the possibility for misunderstandings or differing interpretations. In formulating the items, we were inspired by Thoresen and Hjemdal's (2014) study, although the phrasing used in their study was much more complex. To exemplify, while we asked, 'Has someone forced or threatened you to have intercourse?', they asked, 'Has someone at any time forced you to have intercourse by the use of physical power or by threatening to harm you or someone you have a close relationship with?' While the first item is related to force or threats and the nature of the sexual act, the latter also specifies that the timeframe is unlimited, and the type of force and threats.

These advantages aside, what are the relevant criteria to assess the instrument as being 'good enough' for the production of rape estimates in a youth population?

As a first step, we would look at the rates of rape produced by this and similar instruments in different studies. Studies that produce similar results would speak to the validity of the instrument. In the introduction to this chapter, we detailed the results from two previous studies conducted among the adult population in Norway. Both used sets of behaviourally specific questions, and the results were very similar to what we have found in our study. Based on our four-item measure, close to $9 \%$ of the girls had experienced rape; the corresponding number in the adult study in which a four-item measure was used (Thoresen \& Hjemdal, 2014) was only slightly higher. If we compare our fiveitem measure with the adult study that included incapacitated sexual assault, then the numbers are also quite similar. Among the girls in our study, the prevalence rate was 14\%; among the women in the adult study, the rate was around $16 \%$ (Steine et al., 2012). Given that adults have had more time to accumulate 
rape experiences, these higher rates among adults are as expected. We would also expect that the difference would be quite low, given that young people are considerably more at risk than adults and older people (see Kruse, Strandmoen, \& Skjørten, 2013). But our results differ markedly from the results in Myhre et al.'s (2015) study among 16- and 17-year olds, which used the same fouritem measure as Thoresen and Hjemdal (2014). The prevalence of rape was as low as $3.5 \%$ among girls and $0.2 \%$ among boys. The two-year age span between the respondents in Thoresen and Hjemdal's (2014) study and our study complicates comparisons. These two years of a young person's life most likely see a disproportionate number of sexual assaults compared to previous years. We suspect, however, that the marked difference in part is caused by the composition of the sample in Myhre et al.'s (2015) study. They drew their sample from the telephone directory and reached only $10.4 \%$ of the original sample, from which $66.2 \%$ chose to participate (p. 50), thus making it unlikely that the final sample was representative of the youth population. In addition to the low response rate, the study was not based on a self-completion questionnaire but on telephone interviewing, which involves personal contact between the participant and interviewer. The choice of methods is known to affect people's willingness to disclose sensitive issues, with self-administered methods yielding higher rates compared to methods that involve personal contact, either face-toface or on the telephone (Krumpal, 2013).

A second - and perhaps the most important - step would be to evaluate the degree to which the measure covers the legal definition of rape. We have already commented on why we have excluded the item on involuntary incapacitated sex from the final analysis. Given the high percentage among both girls and boys who reported involuntary incapacitated sex in our study, we would expect that the inclusion of incapacitated rape (penetration or similar) would result in higher prevalence rates for both genders. How an item on incapacitated rape should be phrased is not a straightforward matter. The crime of incapacitated rape covers all forms of penetration by different means - and hence captures a broader set of acts than incapacitated penal-vaginal penetration. It is clear that our four-item measure is too narrow to capture all acts of incapacitated rape. By including the involuntary incapacitated-sex item, we would solve this problem but would at the same time capture a wider set of acts, thus leading to an overly high rape estimate. The solution for future research is to reformulate this item in a manner that would accord with the legal provision on incapacitated rape, or to apply the follow-up method that Thoresen and Hjemdal (2014) used and include confirmed incidents of incapacitated rape in the rape estimate.

What about the broad understanding of rape in the penal code? Rape in the penal code is not limited to 'completed' penetration but also covers incidents of direct contact between sex organs or sex organs and fingers; it also includes masturbation by force or threats of the accused as well as of the victim. The items on rape in our study are all focussed on incidents of rape in a more narrow sense - completed penetration - and hence set the bar 


\section{Kari Stefansen et al.}

higher than the legal code does. Also, these items do not include acts of masturbation by the use of force or threat. How the rape code is to be interpreted is not spelled out in the code itself but is instead to be found in preparatory works and jurisprudence; hence, current law cannot be read directly from the letter of the law. Our instrument is flawed, in the sense that it is an operationalisation of the concrete paragraph on rape and not of current law in action. On the other hand, one could argue that the items we have included cover the main acts that legislators would wish to criminalise (i.e. that they are operationalisations of legislators' intent, so to speak), given, of course, that legislators intend to capture acts of a certain degree of seriousness that would represent more invasive intrusions than unwanted touching and the like. The more general point is that how we should interpret the general notion that population studies should depart from the penal definition of rape is not particularly clear (cf. Fisher \& Cullen, 2000).

Another issue related to operationalisation concerns gender. In line with previous research, our behaviourally specific measures document a clear gendered pattern in the exposure to rape. These measures were intended to capture all acts considered rape under the Norwegian penal code. But the items we have included all address the experience of being penetrated, while the penal code also covers incidents of forcing someone to penetrate someone else, including the assailant. ${ }^{1}$ In the literature, this type of sexual assault is labelled 'made to penetrate', 'forced to penetrate' and 'compelled penetration' (Hlavka, 2017; Stemple \& Meyer, 2014; Weiss, 2010). None of the Norwegian prevalence studies have included questions about 'forced-to-penetrate' rapes, so the prevalence is unknown. Referring to studies from different countries and using different methods and questions, Weare (2018) concluded that 3-5\% of the male population might have experienced rape in this sense.

We do not know how the inclusion of one or more items on 'forced-topenetrate' incidents would have affected the results in our study and the gender difference in rape exposure we found, but such an inclusion would likely mean a higher prevalence among boys than we have reported in this study. The general point is that the use of rape measures that do not include those specific forms of rape that only men and boys experience contributes to constructing rape as the act of being penetrated, and therefore as a predominantly female experience. As for the evaluation of our measure, we would conclude that it is biased, and that the measure should be expanded with items that cover compelled penetration. For girls, however, the instrument most likely yields a more accurate estimate, even if it excludes certain incidents of incapacitated rape.

\section{Conclusion}

Our work in this chapter is inspired by Krebs (2014) and his call to work simultaneously to improve the one- and two-step approaches to the measurement of rape in population studies. We have detailed our experiences from using a one- 
step model based on only five items in a school-based survey among youths. The aim of using these items was to capture rape as it is defined in the Norwegian penal code. Our analyses revealed that those measures that were based on behaviourally specific items yielded higher rates than the one-item general measure did, which held for both genders and for different subgroups of girls. Due to the low N, within-group differences could not be tested for boys hence we do not know if the results are the same for boys. The possibility of including the measure in a school-based survey meant that the response rate was high and that the rape estimates were based on nationally representative data from youths (at least those who were still in school).

Our conclusion is that the measure in some senses is 'good enough'. For girls, it does capture most incidents of rape, according to the legal concept of rape; for boys, it is too narrow and needs to be reworked to include compelled penetration. As an operationalisation of current law on rape in Norway, the measure is probably too strict - given that it is based on the letter of the law and not on how it is interpreted in preparatory works and legal practice. We would caution against including more acts and less clear experiences, however, as the net then could be cast too wide and could include offences that are located in the grey area between rape and other forms of sexual violence.

We would also welcome critical debate of the idea that societies need exact numbers on rape prevalence. There is much to be learned from the goodenough measures used in studies that can provide representative data, especially from studies that monitor developments in rape prevalence over time. We would also caution against the idea that the higher the prevalence, the more trustworthy or useful the study: a high prevalence may be the result of asking overly general questions. In our study, the inclusion of an item about involuntary incapacitated sex (which is not necessarily rape in Norwegian law) had a dramatic effect, for instance, by doubling the percentage of affected boys.

On this note, we will make two final points. First, the one-item general approach has been heavily criticised in international scholarship because it leads to underreporting and a skewed description of who is affected by rape. This critique is well substantiated. The value of general questions is seldom explored or explicated, however. In our study, this question made for an interesting comparison with the behaviourally specific measures. We also believe that it can be very fruitful to follow developments over time in both the prevalence of self-defined rape and the difference between self-defined rape and rape as measured by behaviourally specific questions. One hypothesis concerning the latter would be that the difference will decrease over time because of the heightened attention to the issue of what counts as rape in prevention campaigns and public debate.

Second, the value of prevalence research for monitoring purposes and for prevention efforts needs to be discussed. Prevalence estimates need to be complemented by research that aims to understand the aetiology of rape on the population level. For example, one recent study (Heinskou, Friis, Ejbye-Ernst, \& Liebst, 2017) has illustrated how prevalence studies can be used to identify how 


\section{Kari Stefansen et al.}

rape is located in time, space and relations. In Heinskou et al.'s analyses, the authors examine exposure to rape in relation to a range of factors, including who the assailant was, when it happened and what the consequences of the incident were, both during the situation and afterwards. Such analyses may be developed further to monitor where different forms of rape are socially located and how they decrease or increase over time in different groups. Doing so would then pave the way for more ambitious theoretical work on the social patterns of rape in modern societies.

\section{Note}

1 Penal code section 291, letter c, defines an act to be rape if "through violence or threatening conduct [someone] makes a person engage in sexual activity with another person, or perform[s] acts corresponding to sexual activity on himself/herself'. The code applies the same maximum penalty as committing forceful penetration or similar types as well as incapacitated rape. See https://lovdata.no/dokument/NLE/lov/2005-0520-28/KAPITTEL_2\#KAPITTEL_2.

\section{References}

Cook, S. L., Gidycz, C. A., Koss, M. P., \& Murphy, M. (2011). Emerging issues in the measurement of rape victimization. Violence against Women, 17(2), 201-218.

Council of Europe. (2011). The Council of Europe Convention on preventing and combating violence against women and domestic violence.www.coe.int/fr/web/conventions/ full-list/-/conventions/rms/090000168008482e

Fisher, B. S. (2009). The effects of survey question wording on rape estimates: Evidence from a quasi-experimental design. Violence against Women, 15(2), 133-147.

Fisher, B. S., \& Cullen, F. T. (2000). Measuring the sexual victimization of women: Evolution, current controversies, and future research. Criminal Justice, 4, 317-390.

Gilbert, N. (1993). Examining the facts: Advocacy research overstates the incidence of date and acquaintance rape. In Donileen R. Loseke, Richard J. Gelles \& Mary M. Cavanaugh (Eds.), Current Controversies on Family Violence (pp. 120-132). Newbury Park, CA: Sage.

Haugen, F., \& Efjestad, J. S. (2015). Strafferett - Håndbok (4th ed.). Oslo: Cappelen Damm Akademisk.

Heinskou, M. B., Schierff, L. M., Ejbye-Ernst, P., Friis, C., \& Liebst, L. S. (2017). Seksuelle krcenkelser i Danmark: Omfang og karakter. København: Aalborg Universitet, Københavns Universitet.

Hlavka, H. R. (2017). Speaking of stigma and the silence of shame: Young men and sexual victimization. Men and Masculinities, 20(4), 482-505.

Kahn, A. S. (2004). 2003 Carolyn Sherif award address: What college women do and do not experience as rape. Psychology of Women Quarterly, 28(1), 9-15.

Kahn, A. S., Jackson, J., Kully, C., Badger, K., \& Halvorsen, J. (2003). Calling it rape: Differences in experiences of women who do or do not label their sexual assault as rape. Psychology of Women Quarterly, 27(3), 233-242.

Koss, M. P. (1992). The underdetection of rape: Methodological choices influence incidence estimates. Journal of Social Issues, 48(1), 61-75. 
Koss, M. P. (1993). Detecting the scope of rape: A review of prevalence research methods. Journal of Interpersonal Violence, 8(2), 198-222.

Koss, M. P., Abbey, A., Campbell, R., Cook, S., Norris, J., Testa, M., ... White, J. (2007). Revising the SES: A collaborative process to improve assessment of sexual aggression and victimization. Psychology of Women Quarterly, 31(4), 357-370.

Koss, M. P., Gidycz, C. A., \& Wisniewski, N. (1987). The scope of rape: Incidence and prevalence of sexual aggression and victimization in a national sample of higher education students. Journal of Consulting and Clinical Psychology, 55(2), 162.

Koss, M. P., \& Oros, C. J. (1982). Sexual experiences survey: A research instrument investigating sexual aggression and victimization. Journal of Consulting and Clinical Psychology, 50(3), 455.

Krebs, C. (2014). Measuring sexual victimization: On what fronts is the jury still out and do we need it to come in? Trauma, Violence, \& Abuse, 15(3), 170-180.

Krumpal, I. (2013). Determinants of social desirability bias in sensitive surveys: A literature review. Quality \& Quantity, 47(4), 2025-2047.

Kruse, A. E., Strandmoen, J.-F., \& Skjørten, K. (2013). Menn som har begått voldtekt - En kunnskapsstatus. Oslo: Nasjonalt kunnskapssenter om vold og traumatisk stress.

Løvgren, M., Stefansen, K., Smette, I., \& Mossige, S. (2017). Barn og unges utsatthet for fysisk vold fra foreldre. Endringer i mild og grov vold fra 2007 til 2015. Tidsskriftet Norges Barnevern, 94(2), 110-124.

Ministry of Justice and Public Security. (2008). NOU 2008: 4 Fra ord til handling, Bekjempelse av voldtekt krever handling. Oslo: Ministry of Justice and Public Security.

Ministry of Justice and Public Security. (2012). Handlingsplan mot voldtekt 2012-2014 [Action plan against rape 2012-2014]. Oslo: Ministry of Justice and Public Security.

Mossige, S., \& Stefansen, K. (2007). Vold og overgrep mot barn og unge: En selvrapporteringsstudie blant avgangselever $i$ videregående skole. Oslo: NOVA.

Mossige, S., \& Stefansen, K. (2016). Vold og overgrep mot barn og unge: Omfang og utviklingstrekk 2007-2015. Oslo: NOVA.

Myhre, M., Thoresen, S., \& Hjemdal, O. (2015). Vold og voldtekt i oppveksten: En nasjonal intervjuundersøkelse av 16-og 17-åringer. Oslo: NKVTS.

Pape, H., \& Stefansen, K. (2004). Den skjulte volden: En undersøkelse om Oslobefolkningens utsatthet for trusler, vold og seksuelle overgrep. Oslo: NKVTS.

Phipps, A. (2009). Rape and respectability: Ideas about sexual violence and social class. Sociology, 43(4), 667-683.

Ryan, K. M. (2011). The relationship between rape myths and sexual scripts: The social construction of rape. Sex Roles, 65(11-12), 774-782.

Skilbrei, M.-L., \& Stefansen, K. (2018). Seksuell vold: En samfunnsvitenskapelig innføring. Oslo: Cappelen Damm Akademisk.

Stefansen, K., \& Smette, I. (2006). Det var ikke en voldtekt, mer et overgrep: Kvinners fortolkninger av seksuelle overgrepserfaringer. Tidsskrift for Samfunnsforskning, 47(1), 33-56.

Steine, I. M., Milde, A. M., Bjorvatn, B., Grønli, J., Nordhus, I. H., Mrdalj, J., \& Pallesen, S. (2012). Forekomsten av seksuelle overgrep i et representativt befolkningsutvalg i Norge. Tidsskr Norsk Psykologforening, 49, 951-957.

Stemple, L., \& Meyer, I. H. (2014). The sexual victimization of men in America: New data challenge old assumptions. American Journal of Public Health, 104(6), e19-e26.

Thoresen, S., \& Hjemdal, O. (2014). Vold og voldtekt i Norge: En nasjonal forekomststudie $a v$ vold $i$ et livslopsperspektiv [Violence and rape in Norway: A national prevalence 


\section{Kari Stefansen et al.}

study with a life course perspective.] Norwegian only. Oslo: Nasjonalt kunnskapssenter om vold og traumatisk stress.

Weare, S. (2018). 'Oh you're a guy, how could you be raped by a woman, that makes no sense': Towards a case for legally recognising and labelling 'forced-to-penetrate' cases as rape. International Journal of Law in Context, 14(1), 110-131.

Weiss, K. G. (2010). Male sexual victimization: Examining men's experiences of rape and sexual assault. Men and Masculinities, 12(3), 275-298. 


\title{
6 From the protection of marriage to the defence of equality
}

\author{
The Finnish debate over the sexual \\ autonomy of wives
}

\author{
Riikka Kotanen
}

\section{Introduction}

Intimate relationships are the most common context for rape (UN Women, 2011), and there is a strong correlation between physical and sexual violence within them: the majority of victims of intimate partner violence (IPV) are also victims of rape within the same relationship (e.g. Black et al., 2011). Wider societal awareness of rape in marriage rose gradually alongside second-wave feminism, the growing criticism of violence against women and the lack of state intervention in both the private sphere and in intimate relations (Gavey, 2005). The first empirical research on the topic, conducted in the United States in the early 1980s, revealed the extent of the problem and described its characteristics as well as giving voice to the victims (Russel, 1982; Finkelhorn \& Yllö, 1985). Feminist activism and pioneering research raised awareness, which consequently led a number of countries to criminalise rape in marriage during the 1980s and early 1990s. Nevertheless, marital rape, or rape in intimate relationships more generally, is still legally and socially condoned in many countries: more than 2.6 billion women still live in nations that have not criminalised rape in marriage, either legislatively or judicially, ${ }^{1}$ or where a marital exemption exists allowing husbands to have sexual intercourse regardless of their wives' consent (UN Women, 2011).

The intertwined effects of the social and legal inequality of genders have manifested differently in legislation regulating sex crimes. From the perspective of wives, the most persistent restrictions on their sexual autonomy, in general, relate to the position of women in society. More specifically, these restrictions are connected to the unequal legal position of men and women in the context of marriage resulting in the subordination of wives. The change in legal thinking concerning wives' sexual autonomy is thus connected to the shift in meanings and norms attached to marriage as a social institution. According to a wealth of international comparisons, the Nordic countries rank highest in gender equality from the social and legal perspective. Historically, gender equality was recognised significantly earlier in Nordic countries than elsewhere in Europe, which included the modernisation of legislation (e.g. Pylkkänen, 2009). For example, in 1906, Finnish women were among the first to acquire the vote, and they 
were the first to be able to run for Parliament. Moreover, the marriage acts were completely transformed in the Nordic countries from 1909 to 1929. This was a joint Nordic process in which women's movement took an active part (Melby et al., 2006).

The process resulted in progressive modern regulations that emancipated married women, particularly economically; sexuality and issues related to personal integrity, however, were not addressed within the context of the marriage acts (Melby et al., 2006). But a concurrent process of the revision concerning sexual crimes did take place, where statutes based on religious moral perceptions, such as illicit intercourse, were abolished (e.g. Kotanen, 2010). The revised marriage legislation aimed for a union of equal partners both seen as responsible, independent individuals contributing to the shared marital economy. Moreover, securing women and children economically, even in cases of divorce, was seen as important in terms of ensuring a thriving population; equality was a key feature in the struggle against social problems. According to Melby, Pylkkänen, Rosenbeck and Carlsson Wetterberg (2006), the Nordic marriage reform indicated the growing influence of state responsibility and intervention - the rise of the Nordic welfare state - at the expense of religious views. Yet, they point out that the normative climate in Finland at the time was more conservative than in other Nordic countries, especially in the liberalisation of divorce.

Given the early equalisation in legislation in terms of gender, it comes as no surprise that the Nordic countries were also in the forefront of criminalising rape in marriage. Sweden and Denmark removed a marital exemption from their respective legislations in the early 1960s. In Norway, although its legislation lacked a marital exemption, a 1974 Supreme Court verdict confirmed that rape in marriage was a criminal act. In other Western countries, the wider wave of legal changes securing wives' sexual autonomy started later, during the 1980s (e.g. Yllö, 2016). In Europe, the development was spurred on by the European Parliament's Resolution on Violence against Women of 1986, which urged member states to criminalise rape in marriage. The Finnish case is an interesting exception in the Nordic context: the marital exemption was removed from the Criminal Act in 1994. Finland was following several European jurisdictions that had repealed the marital exemption or had explicitly criminalised rape in marriage in the late 1980s and the early 1990s.

Although Finland provided for the legal equality of spouses within marriage in the 1920s, gaining physical and sexual autonomy took a surprisingly long time, especially in comparison to the other Nordic countries. Using this inconsistency as a starting point, this chapter explores this particular delay in the Finnish legislation by analysing (1) how and why wives' sexual autonomy was rejected in the early $1970 \mathrm{~s}$, (2) what motivated the later criminalisation of marital rape in 1994, and (3) what kind of role the interaction between law and wider societal values played during the legal processes analysed in this chapter (cf. Pylkkänen, 2009). 


\section{The Nordic myth of equality and wives' sexual autonomy}

Because of the Nordic countries' strong egalitarian tendencies, gender equality there has traditionally been understood as a fairly symmetrical balance between men and women (e.g. Pylkkänen, 2009; Julkunen, 2010). Formal equality has long been a valued social and legal element, and the genders have been generally perceived as 'different but equal'. This has been explained by the Nordic emphasis on mutual solidarity and individual responsibility to the state and to the universalism and inclusiveness of the Nordic welfare state model (Nousiainen \& Niemi-Kiesiläinen, 2001). Despite its gender neutrality, the Nordic welfare state has largely been characterised as women-friendly (Hernes, 1987), particularly because the welfare state has created a social environment where the boundaries between public and private have been comparatively easy to cross for women. This has allowed them to enjoy economic independence, resulting in widespread possibilities for self-determination in most areas of life (Kantola, 2006).

Feminist scholars have pointed out a certain lack of polarisation in terms of gender-related issues in the Nordic countries, particularly in comparison to social class. According to this feminist critique, the hegemony of sameness visible, for example, in the way gender differences are often downplayed in the Nordic countries - has created a myth of equality. Such a myth captures situations where equality is understood in society as something that is already realised and complete, as opposed to a future, yet-to-be achieved goal (Nousiainen \& Niemi-Kiesiläinen, 2001). Among the negative consequences of this myth are equality-blind spots such as personal integrity, sexuality and antidiscrimination issues, all of which garnered wider attention only in the late 20th century (Pylkkänen, 2009). The case study from Finland presented in the current chapter highlights not just the above-mentioned difficulties in acknowledging gender differences and women's bodily rights but also the importance of equality as a collective concept and value.

The historical acceptability of marital rape can be explained by a combination of socio-legal ideologies and attitudes to marriage, sexuality and gender inequality. Globally, the widespread acceptance of marital rape has been based on three overlapping ways of reasoning. The first of these justifications is the idea of women as property, particularly in terms of sexuality (Brownmiller, 1975; Schelong, 1994; Yllö, 2016). Thus, rape in marriage was perceived to be as impossible as a husband robbing himself. Early rape laws were enacted to protect men's property interests. For a long time, the complainant was hence either the family or father of an unmarried woman, or the husband of a married woman (Niemi-Kiesiläinen, 2000).

Second, until the modernisation of marriage acts in the early 20th century, a wife was not considered to be a competent legal person within the Western legal tradition. Generally, after entering into a marriage, husband and wife were seen to 'become one'. Due to women's societal and legal position, however, this meant that a wife's legal person was subsumed within that of her husband 
(Pylkkänen, 2009). The idea of marriage as a unity was justified as a way of protecting a harmonious symbiosis within the family; yet in practice, this continued to legitimise husbands' control over their wives (Schelong, 1994).

The third justification relates to the idea of marriage as a contract, and the subsequent interpretation that entering into a marital contract presupposes consent to fulfil a husband's sexual demands under any circumstances (Pateman, 1980; Russel, 1982). The intertwining of the common legal definition of rape as sexual intercourse without the consent of the victim and the idea of continuous marital consent has had a considerable effect on how legally and socially unimaginable rape by a husband has been in many countries until the last decades of the 20th century.

Socio-legal studies on more recent debates concerning marital exemption have shown that the retention of the exemption is often justified by appealing to various ominous scenarios, commonly related to wives' alleged vindictive misuse of rape charges or from difficulties in providing evidence (e.g. Brooks, 1989). But these debates also demonstrate the long-reaching effect of the historical and cultural understandings of marriage discussed above. For example, Mandal (2014) has pointed out that the protection of marriage as a culturally unique and valuable institution was a key concern in India in 2013 when, despite intense debate, the marital exemption was not repealed. Moreover, the understanding that marital rape is not real rape - and thus should be addressed by measures that are considered more suitable, given the private and intimate context - is a widely used justification for retaining the marital exemption and is also firmly connected to historical understandings of marriage (e.g. Williamson, 2017).

From a wider perspective, the historical impact has not been restricted to legislation or wives' sexual autonomy. Because of the presumption of irrevocable marital consent, the courts have used previous (or even potential) consensual sexual intercourse in other contexts, such as current or former intimate partners, cohabitees, or dates, as evidence of ongoing consent, hence making sexual violence accepted or less condemned and the victim less credible (e.g. Jokila, 2010; Lazar, 2010).

\section{Data and method}

The following sections provide an empirical analysis of two legislative processes related to the criminalisation of rape within marriage in Finland. The data were collected as part of a broader study (Kotanen, 2013) and comprise primary and secondary data sets. The primary data set contains all legislative documents from two legal processes: (1) the unsuccessful proposal to criminalise rape within marriage between 1965 and 1970 and (2) the criminalisation of rape within marriage between 1991 and 1994.

Despite the more than two decades that elapsed between the processes analysed in this chapter, the legal procedure for enacting legislation was very similar. In Finland, a governmental proposal (GP), which represents the key document of 
a legislative process, is prepared by Ministry of Justice officials and generally provides an account of the present state of the legislation in question; GPs typically also include an international overview. The proposed legislative revision, its importance, aims and desired effects of implementation are also justified in GPs. The largest difference in terms of the procedure and the documents produced during it is related to the GPs' preparatory process that took place before the proposals were passed to Parliament. In the first process, the GP 52/1970 was based on two preparatory documents: the report of the Committee of Sex Crimes (CSC report 1967: A12) and the Statement of the Supreme Court (SSC, 1969) for the CSC's report. The second process proceeded in two phases: Members of Parliament (MPs) put forward two legislative initiatives (25/1991 and 28/1991) in 1991 , which were handled in subsequent parliamentary hearings. During the following two years, Ministry of Justice officials formed the latter initiative into a GP 365/1992, which they then handed to Parliament in early 1993.

In addition to the above-mentioned documents prepared for GPs, the legislative material includes documents related to the following legislative work of Parliament presented with the GP, including committee reports, written expert statements from committee hearings ${ }^{2}$ and transcriptions of the plenum discussions of Parliament. The legislative data covered in the present study amount to 205 pages.

In order to trace the interaction between law and societal values related to the criminalisation of rape in marriage, a secondary data set was collected to supplement the legislative data. This data set consists of all news articles on IPV published in the largest Finnish newspaper in terms of circulation, Helsingin Sanomat (HS), between 1990 and 1994. In addition, the secondary data include all available written materials related to campaigns and initiatives against IPV by different social actors and government organisations during the same timeframe. The secondary data consist of approximately 450 pages. It is important to note, however, that most documents in the secondary data relate to the latter legislative process, mainly because of the lack of public debate about rape in marriage in the late $1960 \mathrm{~s}$.

The focus of the current qualitative analysis is on legal and social change, and their mutual dynamics, in relation to wives' sexual autonomy. The starting point of the analysis is the Finnish legal historian Anu Pylkkänen's (2009, p. 19) notion that the law has never actually offered protection for women as 'owners of their selves'; instead of integrity, the perspective of the legal regulation of institutions and relations has often been based on the protection of other values, such as economic interests and societal morals. Neither legislative documents nor their ultimate outcomes - legal statutes - are disconnected from the society they are legislated for. Despite the pursuit of neutral objectivity, legal norms and extralegal values tend to interact and intermingle, particularly with topics such as sexuality, reproduction, family issues and personal integrity (Pylkkänen, 2009). As Ngaire Naffine (2007) has stated, the dominant understandings of rape, often implicitly presented as universal and natural, are constructed on a heterosexual male conception of sexuality rather than on women's perceptions and experiences. This becomes visible not only in historical understandings, such 
as the supposed impossibility of raping an unchaste woman, but also more currently in discussions of whether qualifications of rape as a crime should be based on the lack of consent rather than the use of violence or the threat of violence.

The two legal processes analysed in this chapter represent potential moments of legal change. Keeping in mind the intertwining and interacting of legal and social values and understandings, the documents of the legislative data are perceived as a negotiation through which legally and socially acceptable sexuality and sexual acts are defined and through which sexual autonomy is either granted, restricted or denied. The secondary data capture some of the key moments of the social change that has taken place outside the legal realm. The data thus enable the locating of legislators' actions in a wider context: for example, by tracing the moments, measures and/or groups that created pressure for legal change.

The analysis focusses on the justifications provided for the proposed enactment during the legal processes, for example, by examining what kinds of protected interests and societal values these justifications entailed, or what kinds of legal or extralegal understandings of sexuality, marriage and rape as a crime these justifications were based on. Moreover, how the justifications, and the values and interests connected to them, assumed or denied wives' sexual autonomy. The focus is not just on the change in legislation and society but also on the resistance to the change, particularly in the first legal process. A specific point of interest is whether the change, or resistance to it, seems to have been connected to legal culture and tradition or to the wider societal environment. Pylkkänen (2009) has argued that even though the law typically describes the history of winners, spaces of resistance and challenge are always to be found, and that it is equally important to pay attention to the silences: the lack of voices and any unexplained breaks in legal reasoning and conceptualisation. Following this, the present analysis also aims to pinpoint possible missing perspectives and speaks to these silences.

\section{Sexual autonomy in Finnish legislation in the late 1960s: husband's right, wife's duty}

The sexual norms that guided the legal regulation of sex crimes in the 19th century were largely based on religious understandings and beliefs. Accepted and chaste sexual activity was legally and socially institutionalised within the confines of marriage and procreation. This understanding was gradually abandoned during the early 20th century. For example, illicit intercourse was decriminalised in 1926 in Finland, followed by adultery in 1948. Despite the modernisation of the legal regulation of marriage and the repeal of these statutes, when preparations for the revision process began in the mid-1960s, Finnish law on sex crimes was still mainly based on religious-led sexual morals; the legislation on 'chastity crimes" ${ }^{3}$ that was in force at the time had been enacted in 1889. According to the law, forced sexual intercourse could only be interpreted as rape if the perpetrator had been someone other than the husband of the particular woman. A husband could 
only be charged for raping his own wife if he had aided and abetted another man in committing the act. In theory, other statutes, which regulated physical violence instead of sex crimes, allowed for a husband who had committed an act equivalent to rape against his wife to be charged for an assault or coercion. The penal scales for both offences were considerably more lenient compared to rape. ${ }^{4}$

While Sweden and Denmark had abolished marital exemptions in the 1960s, other European countries did not proceed with the matter despite the activity of second-wave feminists. Although social activism for women's rights and gender equality began in Finland later than in the Anglo-Saxon countries and the other Nordic countries, there was emerging activism for sexual liberation and reproductive rights for women as part of protests against restricting sexual norms and gendered double standards (Julkunen, 2010). This activism was connected to a critical, yet somewhat gender-neutral, organisation called Yhdistys 9. ${ }^{5}$ Within the organisation, both women and men campaigned for equality; their actions led to the establishment of the governmental Advisory Board for Equality (TANE ${ }^{6}$ ) in 1972.

In general, contemporary legal scholars considered the legal position of men and women to be fairly equal, even though it was acknowledged that the legislation still consisted of certain unequal statutes. For example, it was criticised that a wife was obliged to take her husband's surname upon marriage under Finnish law (Mickwitz, von Essen \& Nordgren, 2008). None of the deficiencies highlighted at the time were related to women's physical or sexual integrity; instead, questions related to economic and labour rights were the priority. While this was a joint Nordic blind spot, one specific reason for the invisibility of physical and sexual integrity, particularly in Finland, has been the comparatively late modernisation of Finnish legislation and society that has hindered the acknowledgement of individual rights (Pylkkänen, 2009). The shift from an agrarian society to a Nordic welfare state was largely delayed due to the destructive wars in the earlier half of the last century. From the legal perspective, apart from the protection of property and rights related to ownership, fundamental rights were largely absent in Finnish legal discussions before the 1970s (Pylkkänen, 2012). The first actual listing of fundamental rights was introduced only in 1995 after a long revision process of the constitution. The Nordic culture of sameness, and the tendency to avoid open conflict between genders, has also been particularly strong in Finland. One indicator of this was the channelling of social activism through Yhdistys 9 rather than through a women's movement (Jallinoja, 1983).

The preparatory work for the new Sex Crime Act began in December 1966, when the Finnish government appointed the Committee of Sex Crimes. After a year, the CSC handed its report to the government which then requested a statement from the Supreme Court. Following the Supreme Court's suggestions, the report was revised by Ministry of Justice officials into GP 52/1970, which was eventually handed to Parliament in 1970. The CSC report (1967: A12) stated that the current criminal justice system was based on conceptions connected to religiously based morality, and hence heterosexual marriage had 


\section{Riikka Kotanen}

been seen as the only lawful context for sexual relations. However, the CSC estimated in its report that during the 20th century, gender equality had developed to the point that 'almost all differences between the genders have disappeared within society'. This highlights how long-lived the Nordic ethos of 'already-achieved equality' is.

The general justifications for the revision of the regulation of sex crimes represented a clear separation from the previous regulation. In other words, instead of protecting chastity and other religious-based moral sentiments related to sex and sexuality, the focus of the justifications was on the protection of individual autonomy, especially in situations where one's autonomy had been denied due to 'intimidation or violence'. According to the report (CSC 1967: A12), instead of protecting only sexual morals and the chastity of society, the Criminal Law should prioritise the protection of individual autonomy. The CSC utilised the revised Swedish Sex Crime Act from 1962, which included the criminalisation of rape in marriage, as a model for its proposal. The Swedish example was also one of the key justifications for initiating the criminalisation of marital rape in Finland. Despite proposing the removal of the marital exemption, the CSC's attitude towards the potential criminalisation remained ambivalent. In its report, the modern idea about individual autonomy as the core protected interest of law was intermingled with the understanding that marriage was meant to provide ongoing consent:

... marriage can no longer be considered to establish sexual authority for a husband over his wife; sexual intercourse requires mutual consent even within a marriage: although getting married justifies an assumption that such consent has been given.

(CSC, 1967: A12)

The Supreme Court was solicited for a written statement to the committee's report. In its statement (SSC, 1969), the Supreme Court opposed the proposal for criminalising rape in marriage. It was considered too modern and unsuitable for Finland (Kotanen, 2013). When GP 52/1970 was finally handed to Parliament, the Supreme Court's position was straightforwardly adopted into the proposal. Several justifications, such as that 'criminalisation would be against the Finnish people's sense of justice', were replicated word for word from the Supreme Court's statement.

The most significant impediments to criminalisation found in the data are (1) the denial and questioning of the occurrence of marital rapes, (2) the conceptual inextricability of marriage and sexual intercourse, and (3) the definition of rape as a chastity crime in the legislation (in force at the time) and governmental proposal. The justification for the opposition to criminalisation referred to the conception that such acts are not committed 'in practice between spouses living in a normal marriage', and also the possible harm was assessed as being so minor that it did not require any intervention. Marriage and sexual intercourse were connected to each other so closely in the legal documents that they appear 
indivisible. Only two addresses held in Parliamentary hearings challenged the 'marital duties' of a wife to resign herself to sexual intercourse with her husband, even against her will. These addresses represented modern ideas about gender equality and women's human rights, which were more characteristic of the latter part of the data. In them, wives were also acknowledged as victims of sexual violence - a perspective that is missing elsewhere in the data from the 1960s (Kotanen, 2013).

Even though the marital exemption is explicitly relational by definition, in the data, the exemption also has spatial restrictions. According to GP 52/1970 and the Supreme Court's statement (SSC, 1969), wives' marital duties will cease only in cases where spouses are separated due to an approaching divorce. Only living in separate households is considered a sufficient indicator for the withdrawal of ongoing consent. The Supreme Court's statement highlights the discontinuation of sexual duties due to physical and spatial separation. The withdrawal of the marital exemption is justified because merely forcing oneself into another person's private sphere is a criminal offence in such situations. The interpretation of who a specific space belongs to thus becomes an important qualifier of rape. From a spatial perspective, the private sphere becomes a protector of wives' sexual autonomy:

In cases of separation, one cannot assume without question that consent to sexual intercourse related to marriage would exist. ... It would be unfair to exclude wives from legal protection in these cases ...

(SSC, 1969)

Discussion about how the section on sexual crimes should be named within the Criminal Act illustrated how firmly rooted religiously based sexual morality and conservative attitudes remained in the late 1960s in the context of Finnish legislation. The CSC suggested that the heading of the particular section should be updated from 'Chastity crimes' to 'Sex crimes', which it regarded as more suitable and modern. The Supreme Court opposed this proposal and this was adopted into GP 52/1970. The understanding of rape, and other sex crimes, as unchaste is one of the key explanations for the incongruity of marriage and rape. From the point of view of marital rape, this understanding proved to be a significant obstacle to its criminalisation. According to these two documents, a chastity-crime charge would be 'inappropriate' and 'shameful' in the context of marriage. Classifying marital intercourse as a crime against sexual morals and chastity would thus be impossible, as doing so would be contradictory to the idea of marriage as the only legitimate context for intercourse. In the data, this contradiction was regarded as so significant that not even the most grievous violation of a wife's sexual autonomy could be considered to be penalised as a chastity crime, as that would imply that these acts, and consequently the marriage they were committed within, were immoral: 
In other cases [i.e. when spouses are not separated], not even sexual acts that violate the autonomy and freedom of the other spouse in an aggravated manner should be penalised as chastity crimes ...

(SSC, 1969)

The quote above is important from two perspectives. First, its gender-neutral articulation, particularly in a legal context where rape can only be inflicted on a woman, is a good example of the tendency to downplay gender differences. Second, the quote reveals how inconsistent and contradictory attitudes towards marital rape were at the time. The same action is defined within one sentence, first, neutrally as a sexual act, and immediately after as a gross violation of rights. The statement hence seems to include a clear awareness of the problematic nature of, and the possibly serious consequences connected to, rapes inflicted on wives. Nevertheless, wives' sexual autonomy was consciously defined more narrowly in comparison to other women; within marriage, sexual autonomy was seen specifically as the right of the husband.

In the late1960s, the violation of a woman's sexual autonomy qualified as a crime only if the act could be interpreted as unchaste; in other words, if it simultaneously violated conservative, religion-based sexual morals. Since forced intercourse with one's own wife was not regarded as such a violation at the time, these moral norms were, in practice, more valued as an interest of legal protection than was married women's sexual autonomy. Moreover, the idea of a woman's ongoing consent was not applied only to married women in subsequent criminal law enactment. Other types of relationships between 'the offender and the woman' were also considered as extenuating circumstances, and thus a possible remission of sentence. This view was not questioned at all in the data. However, in addition to the CSC's original suggestion to remove the marital exemption, the close result of the parliamentary vote -77 in favour versus 86 opposed to criminalisation - implies that the legal and social understandings of marital rape had already started to diverge.

\section{Criminalising rape in marriage in 1994: in defence of equality}

The understandings attached to rape slowly began to change in Western countries from the 1970s onwards. Anglo-American feminist activists, followed by feminist researchers, were at the forefront of raising awareness about rape as a social and structural problem by emphasising the position and rights of victims (e.g. Millet, 1970; Connel \& Wilson, 1974). Instead of involuntary sex, rape was defined not just as a crime but as an exercise of gendered power (Brownmiller, 1975). General attitudes towards marital rape, however, did not change considerably until the late 1980s and early 1990s (Gavey, 2005). The United Nations General Assembly adopted the Convention on the Elimination of All Forms of Discrimination against Women (CEDAW) in 1979, which was instituted in 1981. Internationally, the UN and CEDAW had an important role in expediting legislative changes on marital rape in Europe in the late 1980s and early 1990s (Utriainen, 2010; van Leeuwen, 2013). 
In Finland, marital rape was publicly acknowledged after it became the subject of critical attention in the late 1970s as part of the book Violence within Marriage (Germain et al., 1978). Nevertheless, no legislative initiatives were undertaken for criminalisation until the early 1990s, even though the social atmosphere and attitudes had changed considerably in Finland during these two decades. International obligations spurred on gender equality and the legitimation of women's rights; for example, the first Equality Act (609/1986) was enacted in 1986 largely due to legal preparations for the pending ratification of CEDAW. The status of marriage as an institution had begun to diminish from the 1970s, and societal changes influenced attitudes to marital rape. According to a survey published in 1993 , only $10 \%$ of men and $8 \%$ of women were in favour of the idea that rape should be punished differently when committed within marriage (Haavio-Mannila \& Kontula, 1993). Still, in the early 1990s, Finland remained among the few Western countries not to have criminalised rape within marriage.

In this legislative process, the interaction of law and societal values occurs in the form of extralegal social activity and pressure directed towards legislators. The contradiction between the changed societal attitudes and the extant legislation induced critical public discussion. In particular, the members of TANE's recently established division of gendered violence actively promoted the cause against gendered violence (e.g. Sosiaali- ja terveysministeriö, 1991). It was not just the feminist activists who were raising critical awareness, however. For example, two editorials in Helsingin Sanomat pressed for the criminalisation of marital rape (HS 13.6.1991; HS 29.11.1991), and MPs prepared two separate legislative initiatives on criminalisation. The first initiative 25/1991 was made by a group of MPs who all were representatives of the Left Alliance. ${ }^{7}$ At the time, the initiative appeared rather radical in the Finnish context, suggesting not only criminalising rape in marriage but also, for example, subjecting assault in the private sphere to public prosecution as well as a change in the legal definition of rape to redefine it as gender-neutral regarding rape victims. ${ }^{8}$ The second legal initiative 28/1991 was signed by a group of MPs from several political parties; the initiative's more moderate aim was to criminalise marital rape by removing the marital exemption and eliminating from the statute the sentence defining the relationship between the offender and victim as a possible mitigating circumstance.

After Parliamentary hearings addressed the initiatives, the cause progressed slowly. According to Pirjo Pehkonen (2003), who has analysed anti-violence activism within the Finnish women's movement, members of TANE who actively worked to promote the cause pointed out that there was clear reluctance on the part of the Ministry of Justice to make any progress in the matter. However, the TANE members eventually managed to convince the then Minister of Justice of the importance of criminalisation. GP 365/1992, based on the latter legal initiative 28/1991, was handed to Parliament in January 1993. Similar reluctance by the Ministry of Justice also appeared later in the 1990 s in relation to the increasing demands for legal regulation of 


\section{Riikka Kotanen}

IPV. For example, for several years before the enactment of legislation to introduce the restraining order in 1998, feminist activists, the media and MPs had pressured the Ministry of Justice to act (Kotanen, 2018). The ministry's reluctance seems to have been based largely on a lack of recognition of the scale and prevalence of IPV as well as an understanding that such violence was a problem of social rather than criminal justice policy (NiemiKiesiläinen, 2004; Kotanen, 2013).

In GP 365/1992, the explicit justification for legislative alterations was to strengthen the individual's right to sexual integrity and autonomy. A closer analysis of the data, however, shows that sexual autonomy was not the only protected interest: such autonomy was only one of several elements of equality, which was the key interest to be protected. This was particularly related to the Parliamentary hearings. In their addresses, the MPs presented Finnish equality as incomplete, particularly due to the marital exemption, as though the Criminal Law was calling Finnish equality into question. The proposed legal changes would provide a means for rectifying the situation and pursuing more comprehensive equality within legislation and society. Equality has three dimensions in the data: (1) equality between spouses, (2) equality among women, and more generally, (3) equality between genders.

This initiative is aimed as a part of actions to promote gender equality.

... The aim has been, as it has been in the legislation in general, to increase equality between spouses, and their independent right to decide whether to stay married or to end the marriage has been vitally reasserted .... The alteration of this statute is important, above all, with respect to principles.

(GP 365/1992)

Particularly in GP 365/1992, prepared by the Ministry of Justice, criminalisation appears as a 'principled revision'; in other words, as a legislative alteration whose importance lies in its principles. This is consistent with the lack of references to the real people who are affected by marital rape despite the research and statistics that by then had provided substantial information about these acts. In terms of missing perspectives, neither victims of rape nor offenders are mentioned at all in the GP.

The most weighty and concrete motivations for criminalisation are the international demands and agreements connected to Finland's approaching EU membership. Finnish feminist researchers have pointed out that the international agreements, as well as EU membership in general, have been the most significant reasons for promoting women's rights in Finland, particularly in terms of gendered violence (Kantola, 2006; Nousiainen \& Pentikäinen, 2013). In the GP, however, the binding force of these agreements is explicitly defined as having an effect 'in principle': 
The assembly [against violence towards women consisted of 16 ministers from Western European countries] passed a declaration that was signed by Finland ... in April 1991. In terms of legislation, the declaration states that physical violence against women is a crime within and outside marriage ... and that, in principle, physical and sexual violence has to be punished as severely when it is committed within marriage ...

(GP 365/1992)

In addition to the international agreements, another tangible international motivation for criminalisation was Finland's international reputation, especially vis-à-vis other Nordic countries and EU member countries. GP 365/1992 includes a comprehensive cross-European legal review in terms of marital rape. The partial revision, limited to the one statute that included the marital exemption, was validated by the pressure created by the European example in the situation where comprehensive revision of the Criminal Act was already in progress. The MPs emphasised in the Parliamentary hearings how harmful the current situation was to Finland's reputation. They highlighted criminalisation as an advantage not just for women but especially for Finland as a nation:

... we are enacting this [statute] separately so that we are not the only Western European country ... to not fulfil the international agreements we have concluded in this respect. This is the reason for handing this partial revision over to Parliament.

(Minister of Justice in a parliamentary hearing, 16 February1993)

Framing the criminalisation of marital rape as a national question of Finland's international image is not entirely exceptional. Highlighting gender-neutral national interests, such as the national economy, labour policy, or public health, has been a tradition in Finland within legal revisions for improving the societal position of women. This has been interpreted as a national strategy to avoid open conflict between genders (Rantalaiho, 1994; Julkunen, 2010). A marginal group of male MPs displayed an objection to criminalisation during the Parliamentary hearings; their addresses defended values based on the conservative sexual morals that dominated legal discussion in the 1960s (Kotanen, 2013). Similarly to other countries, they justified retaining the marital exemption through a presumption of potential misuse (e.g. Mandal, 2014; Williamson, 2017).

\section{Discussion}

The purpose of this study was to analyse justifications for the late criminalisation of marital rape in Finland by asking (1) how and why wives' sexual autonomy was rejected in the early 1970s, (2) what motivated the later criminalisation of marital rape in 1994 and (3) what kind of role the interaction between law and wider societal values played during the legal processes analysed in this chapter. The analysis has examined what kinds of legal or 
extralegal values, as well as understandings of sexuality, marriage and rape as a crime, these justifications were based on.

When the joint Nordic reform of marriage acts took place in the 1920s, the equalisation of marriage at the expense of religious views provoked more opposition in Finland than in the other Nordic countries due to Finland's conservative normative climate (Melby et al., 2006). According to the present study, conservative views still held a strong hold in the legal realm of marriage four decades later. The key justifications for the decision not to repeal the marital exemption were a mixture of historical understandings of marriage as a husband-led unity and as ongoing sexual consent on the part of the wife, combined with religiousbased moral views that mainly protected the moral reputation of marriage as an institution. Sexuality appears as a husband's right, a privilege guaranteed by his wife's marital agreement. From the female perspective, sexuality is a submissive duty. Wives' sexual autonomy is weighed against the chastity of marriage, which becomes crystallised in a conflict between the contemporary understanding of rape as an unchaste act and marriage as the solely appropriate and legitimate unity, even in cases of sexual violence.

The strong resistance to change within the legal realm highlights how inappropriate and alien the initiative, inspired by other Nordic countries, was seen in Finland. In some respects, this reflects Indians' objection to repealing the marital exemption; Mandal (2014) refers to this type of situation as 'cultural nationalism'. Marriage as an institution was perceived as a culturally unique part of society's morality, whereas the criminalisation of marital rape represented something that came from outside the familiar, cultural values. The prioritisation of conservative views, in terms of marriage as an institution, and the acceptance of wives' lack of sexual autonomy are particularly striking because, at the time, the Nordic countries had a well-established tradition of mutually revising and harmonising their legislation. One reason that the resistance to the change appeared fairly unanimous was the lack of social debate about the issue. Although sexual double standards were criticised, sexual integrity was not yet on the agenda (Pylkkänen, 2009). The close parliamentary vote, however, indicated that despite the silence and lack of discussion in the social and legal contexts, many considered the unequal position of wives to be unjust.

In the early 1990s, the change arose mainly through extralegal social activity aiming to bring the legal understanding of equality in line with societal understanding. Contrary to the situation in the late 1960 s, criminal law, and the old-fashioned and unequal values it embodied in terms of the regulation of sex crimes, were widely perceived as alien. They uncomfortably challenged something socially and culturally important: that is, the myth of equality (cf. Nousiainen \& NiemiKiesiläinen, 2001). In general, sexuality was only incidentally touched upon, and when it was, sexuality appeared as an equal right of men and women. Similarly to the late 1960s, resistance to change occurred on the part of legislators. The Ministry of Justice's reluctance hindered the legal process; they were later primarily motivated by the demands of Finland's recent EU membership.

The Nordic way of downplaying gender differences appeared in the 1990s as a calculated, traditional way of political argumentation for women's rights in 
Finland (cf. Rantalaiho, 1994; Julkunen, 2010). But this tendency to downplay was also a probable cause for the invisibility of female victims of sexual violence as well as the male perpetrators in GP 365/1992, the key document of the legal process. This tendency also presents an interesting contrast to the feminist social activism towards violence against women that started at the beginning of the 1990s, which was the main domestic motivation behind the legal change that consequently launched a wider process of legal reforms, particularly in relation to IPV (e.g. Kotanen, 2013, 2018). In general, however, this feminist redefinition of gender-neutral domestic violence to gender-based violence clearly had some influence on legal argumentation at the time.

The legal regulation of sexual crimes has been reformed in Finland on multiple occasions after revoking the marital exemption. The Act on Sexual Crimes was completely revised in 1999 to reinforce victims' individual autonomy and sexual self-determination as the main objects of protection. After a critical social debate and intensive campaigning by the Finnish section of Amnesty International, the legislative subsections on rape were further revised in 2011 and 2014 by widening the range of the punishability of rape (Kotanen \& Kronsteadt, 2019). As of 2019, legislators are yet again under extralegal pressure to change the Act on Sex Crimes following Sweden's 2018 reform. The citizens' initiative called 'Suostumus2018,9 demands that the current definition of rape, based on the use of physical force or the threat of violence, be changed to one based on lack of consent.

\section{Notes}

1 Different countries have criminalised rape in marriage either by changing the legislation regulating sex crimes or by changing the judicial customs, such that these acts are dealt with in courts in a similar manner to rape committed outside marriage.

2 The expert statements related to the attempt to criminalise rape in marriage in the late 1960 s were not as comprehensively documented in literal form as the expert statements in the early 1990s and hence offer very little additional information.

3 All quotes from the research data have been translated from Finnish to English by the author.

4 At the time, the maximum sentence for rape was 10 years in prison, while the maximum penalties for assault and coercion were two years and one year, respectively. The maximum penalty was a fine for cases of minor assaults.

5 'Association 9' in English.

6 From the Finnish for Tasa-arvoasiain neuvottelukunta.

7 A left-wing political party in Finland.

8 According to the legislation in force in 1991, rape could only be inflicted on women.

9 'Consent 2018' in English; see http://suostumus2018.fi/.

\section{References}

Black, M., Basile, K., Breiding, M., Smith, S., Walters, M., Merrick, M., ... Stevens, M. (2011). The National Intimate Partner and Sexual Violence Survey: 2010 summary report. Atlanta: National Center for Injury Prevention and Control.

Brooks, R. (1989). Marital consent in rape. Criminal Law Review, 877-887. 


\section{Riikka Kotanen}

Brownmiller, S. (1975). Against our will: Men, women, and rape. New York: Bantam Books.

Connel, N., \& Wilson, C. (1974). Rape: The first sourcebook for women by New York radical feminists. New York: New American Library.

Finkelhorn, D., \& Yllö, K. (1985). License to rape: Sexual abuse of wives. New York: The Free Press.

Gavey, N. (2005). Just sex? The cultural scaffolding of rape. New York: Routledge.

Germain, S., Mattila, K., Polkunen-Gartz, M.-L., \& Törnroth, C. (1978). Väkivalta avioliitossa. Helsinki: Tammi.

Haavio-Mannila, E., \& Kontula, O. (1993). Seksuaalinen lähentely, ahdistelu ja maksettu seksi. In O. Kontula \& E. Haavio-Mannila (Eds.), Suomalainen seksi: Tietoa suomalaisten sukupuolielämän muutoksesta (pp. 311-342). Porvoo, Finland: WSOY.

Hernes, H. M. (Ed.). (1987). Welfare state and women power: Essays in state feminism. Oslo: Norwegian University Press.

Jallinoja, R. (1983). Suomalaisen naisasialiikkeen taistelun kaudet. Juva, Finland: WSOY.

Jokila, H. (2010). Tahdonvastainen suostumus ja liiallisen luottamuksen hinta: Raiskauksen ja muiden seksuaalirikosten oikeudellisen tiedon konstruktiot. Helsinki: Suomalainen lakimiesyhdistys.

Julkunen, R. (2010). Sukupuolen järjestykset ja tasa-arvon paradoksit. Tampere, Finland: Vastapaino.

Kantola, J. (2006). Feminists theorize the state. Basingstoke, UK: Palgrave Macmillan.

Kotanen, R. (2010). Omistussuhteesta autonomiaan? Raiskauksen kriminalisoiminen avioliitossa ja aviovaimon seksuaalinen itsemääräämisoikeus Suomessa. Oikeus, 4, 369-395.

Kotanen, R. (2013). Näkymättömästä näkökulmaksi - Parisuhdeväkivallan uhrit ja oikeudellisen sääntelyn muutos Suomessa. Helsinki: Unigrafia.

Kotanen, R. (2018). The rise of the crime victim and punitive policies? Changes to the legal regulation of intimate partner violence in Finland. Violence against Women, 24 (12), 1433-1453.

Kotanen, R., \& Kronsteadt, J. (2019). Attribution of responsibility for sexual crimes beyond individual actors - Construction of responsibility of offenders, victims and society in laypersons' explanations. International Review of Victimology, 25(3), $358-374$.

Lazar, R. (2010). Negotiating sex: The legal construct of consent in cases of wife rape in Ontario, Canada. Canadian Journal of Women and the Law, 22(2), 329-363.

Mandal, S. (2014). The impossibility of marital rape. Australian Feminist Studies, 29(81), 255-272.

Melby, K., Pylkkänen, A., Rosenbeck, B., \& Carlsson Wetterberg, C. (2006). The Nordic model of marriage. Women's History Review, 15(4), 651-661.

Mickwitz, M., von Essen, A., \& Nordgren, E. (2008). Roolien murtajat: Tasaarvokeskustelua 1960-luvulta 2000-luvulle. Helsinki: Gaudeamus.

Millet, K. (1970). Sexual politics. New York: Doubleday.

Naffine, N. (2007). Feminism \& criminology. Cambridge, UK: Polity Press.

Niemi-Kiesiläinen, J. (2000). Mitä seksuaalirikoslailla halutaan suojella? In P. Honkatukia, J. Niemi-Kiesiläinen, \& S. Näre (Eds.), Lähentelyistä raiskauksiin: Tyttöjen kokemuksia häirinnästä ja seksuaalisesta väkivallasta (pp. 137-168). Helsinki: Nuorisotutkimuseura.

Niemi-Kiesiläinen, J. (2004). Rikosprosessi ja parisuhdeväkivalta. Helsinki: WSOY.

Nousiainen, K., \& Niemi-Kiesiläinen, J. (2001). Introductory remarks on Nordic law and gender identities. In K. Nousiainen, Å. Gunnarsson, K. Lundström, \& J. Niemi-Kiesiläinen 
(Eds.), Responsible selves. Women in the Nordic legal culture (pp. 1-22). Aldershot, UK: Ashgate.

Nousiainen, K., \& Pentikäinen, M. (2013). Rise and fall of the CEDAW in Finland: Time to reclaim its impetus. In A. Hellum \& H. Aasen (Eds.), Women's human rights: CEDAW in international, regional and national law (pp. 557-587). Cambridge, UK: Cambridge University Press.

Pateman, C. (1980). Women and consent. Political Theory, 2, 149-168.

Pehkonen, P. (2003). Naisen puolesta, ei miestä vastaan: Suomalainen naisliike väkivaltaa vastustamassa. Joensuu, Finland: Joensuun yliopisto.

Pylkkänen, A. (2009). Trapped in equality: Women as legal persons in the modernisation of Finnish law. Helsinki: Finnish Literature Society.

Pylkkänen, A. (2012). Muodollisen tasa-arvon pitkä historia ja sen sisäänrakennetut erot. In J. Kantola, K. Nousiainen, \& M. Saari (Eds.), Tasa-arvo toisin nähtynä (pp. 57-72). Helsinki: Gaudeamus.

Rantalaiho, L. (1994). Sukupuolisopimus ja Suomen malli. In A. Anttonen, L. Henriksson \& R. Nätkin (Eds.), Naisten hyvinvointivaltio (pp. 9-30). Tampere: Finland: Vastapaino.

Russel, D. (1982). Rape in marriage. Bloomington: Indiana University Press.

Schelong, C. (1994). Domestic violence and the state: Responses to and rationales for spousal bettering, marital rape and stalking. Marquette Law Review, 1, 79-120.

Sosiaali- ja terveysministeriö. (1991). Tasa-arvojulkaisuja 1/1991: Naisiin kohdistuva väkivalta. Helsinki: Sosiaali- ja terveysministeriö.

UN Women. (2011). Progress of the world's women 2011-2012: In pursuit of justice. New York: UN Women.

Utriainen, T. (2010). Raiskaus rikosoikeudellisena ongelmana. Rovaniemi, Finland: Lapin yliopistopaino.

van Leeuwen, F. (2013). Women's rights are human rights! In A. Hellum \& H. Aasen (Eds.), Women's human rights: CEDAW in international, regional and national law (pp. 242-267). Cambridge, UK: Cambridge University Press.

Williamson, A. (2017). The law and politics of marital rape in England and Wales 1945-1994. Women's History Review, 26(3), 382-413.

Yllö, K. (2016). Prologue: Understanding marital rape in global context. In K. Yllö \& M. Torres (Eds.), Marital rape: Consent, marriage, and social change in global context (pp. 1-8). Oxford, UK and New York: Oxford University Press.

\section{Original sources}

Eduskunnan täysistuntokeskustelu HE 365/1992 Hallituksen esitys eduskunnalle laiksi rikoslain väkisinmakaamista ja vapautta loukkaavaa haureutta koskevien säännösten muuttamisesta, 16.2.1993. (Parliamentary hearing, 16 February 1993).

HE 52/1970 vp Hallituksen esitys eduskunnalle siveellisyyteen kohdistuvien rikosten rangaistuksia koskevan lainsäädännön uudistamisesta. (Governmental proposal [GP] 52/1970).

HE 365/1992 vp Hallituksen esitys eduskunnalle laiksi rikoslain väkisinmakaamista ja vapautta loukkaavaa haureutta koskevien säännösten muuttamisesta. (Governmental proposal [GP] 365/1992).

Helsingin Sanomat, 13 June 1991, editorial: ‘Synkän kolkko suomalainen avioliitto'. Helsingin Sanomat, 29 November 1991, editorial: ‘Avioraiskauksestakin rikos'. 


\section{Riikka Kotanen}

KM 1967: A12. Seksuaalirikoskomitean mietintö. Helsinki 1968. (Report of the Committee of Sex Crimes [CSC] 1967: A12)

Korkeimman oikeuden lausunto ehdotuksesta hallituksen esitykseksi eduskunnalle siveellisyyteen kohdistuvien rikosten rangaistuksia koskevan lainsäädännön uudistamisesta. Selostuksia ja tiedonantoja Korkeimman oikeuden ratkaisuista vuonna 1969. Helsinki, 1970. (Statement of the Supreme Court [SSC] 1969)

LA 25/1991 vp Ehdotukset laeiksi rikoslain 20 ja 21 luvun sekä maksuttomasta oikeudenkäynnistä annetun lain 1 §: n muuttamisesta. (Legal initiative[LI] 25/ 1991).

LA 28/1991 vp Ehdotus laiksi rikoslain 20 luvun muuttamisesta. (Legal initiative [LI] 28/1991). Laki naisten ja miesten välisestä tasa-arvosta (609/1986). 


\title{
7 Towards voluntariness in Swedish rape law
}

\section{Hyper-medialised group rape cases and the shift in the legal discourse}

\author{
Gabriella Nilsson
}

\section{Introduction and aim}

In December 2017, the then Swedish Prime Minister Stefan Löfven demanded, 'Sex should be voluntary. If it is not voluntary, then it is illegal' (Aftonbladet, 17/12 2017). ${ }^{1}$ The background of his statement was the recommendation made already in 2016 by the Sexual Offences Committee to introduce a consent-based regulation in the sexual offences legislation instead of the force-based existing legislation (SOU, 2016:60). Already prior to the inquiry by the Sexual Offences Committee, the legislation had been subjected to two recent reviews, resulting in an extensive reform in 2005 and legislative amendments in 2013. On both occasions, consideration was given to amending the legislation to base criminal liability on the absence of consent, but it was decided against such a proposition. In 2016, however, the conclusion was the reverse:

Even though several amendments have been made to sexual offences legislation in the past decade, there are still situations where sexual integrity and self-determination are violated and where it is doubtful whether there is sufficiently strong protection from the violation under criminal law. [...] In the choice between supplementing the present legislation and changing it completely, we have concluded that the law has to be changed.

(SOU, 2016:60)

Thus, the committee proposed that 'criminal responsibility is borne by a person who performs sexual intercourse or another sexual act that, with regard to the seriousness of the violation, is comparable to sexual intercourse, with a person who is not participating voluntarily' (SOU, 2016:60, p. 43). Additionally the punishable area was expanded by the introduction of a liability for negligence, including both cases where the perpetrator actually realised that it might be the case that participation in a sexual act was not voluntary, but still chose to perform the sexual act, and the cases where the perpetrator could and really ought to have done something to come to a realisation of whether the participation was voluntary or not (SOU, 2016:60, p. 53). 
The Swedish government chose to propose the change that was recommended by the committee and, on 23 May 2018, the parliament voted for a legislation based on the requirement of consent (Govt. Bill. 2017/18:177). On 1 July 2018, the new legislation entered in force (SFS 2018:618).

Internationally, this legal shift coincides with an increased criticism the last few decades towards the judicial procedure and the legal construction of rape, and a great number of changes in sexual offences legislation (Bumiller, 2008; McGlynn \& Munroe, 2010; Spohn \& Horney, 2013). Nonetheless, it is surprising how little scope the legislative changes in other countries, in particular the countries where consent-based legislation has come into force far earlier than in Sweden, have been given in the Swedish debate on sexual offences.

The main argument in this chapter is that in Sweden, this legal shift was the result of a discursive process that since the mid-1990s, in particular, was taking place in news reports and debate about the legal handling of a number of hyper-medialised Swedish group rape cases (cf. Wennstam, 2002; Leijonhufvud, 2015; Nilsson, 2018). The aim is to highlight how a gradual change towards voluntariness was reflected in, and largely pushed by, news reports and debate about these cases.

\section{Material}

The chapter uses empirical material gathered as part of a larger study of how rape is portrayed in Swedish news media from 1990 to 2015 (see Andersson et al., 2016). Within the scope of this study, an initial search was conducted of all newspaper articles about rape in the tabloid Expressen. In the first overview of these articles, it was apparent that a number of particularly hyper-medialised cases of group rape seemed to work as starting points and discursive arenas to debate legislation and call for legal changes (Nilsson, 2018). These cases were in particular the so-called 'Södertälje case' (1995); the 'Rissne case' (2000); the 'Tumba case' (2003); the 'Husby case' (2004); the 'Motala case' (2004); the 'Stureplan case' (2007); the 'Tensta case' (2013) and the 'Bottle rape' (2013).

An additional search was conducted where all newspaper articles concerning these cases, both news reports, editorials and opinion pieces, published mainly in the six largest Swedish morning papers and tabloids, were retrieved. The articles were closely read focussing on how they had influenced a legislative change, including how new terms was introduced, discussed and implemented. In this chapter, the four cases that most clearly illustrated the gradual change towards consent-based legislation have been selected for the analysis. In the analysed articles, aside for the journalists themselves, the voices from the courts are heard in the form of lawyers and prosecutors involved in the cases, as well as is the voice of the legislature, usually represented by the minister of justice. 


\section{Analytical framework}

The analytical starting point is a discourse theoretical perspective (Laclau \& Mouffe, 1985). Central to discourse theory is for the meaning of language to be regarded as contingent. By relating different terms to one another in a certain discourse, their meaning is (temporarily) fixed. Accordingly, a discourse can be described as a context in which the ambiguous meanings of the central terms, what Laclau and Mouffe call nodal points, have been reduced for the purpose of certainty and clarity. The legal discourse is one context in which the certainty and clarity of the nodal points is particularly important, especially from the perspective of legal certainty. In the legal discourse on rape, the nodal points are general legal principles but also the specific terms stipulated in the legislation, e.g. force and intent.

A discourse is influenced not only by the terms it includes, but also by the exclusion of terms what Laclau and Mouffe describe as the discursive field. As a discourse such as the legal discourse is constituted in relation to the surrounding discursive field, it risks being undermined by the articulations taking place therein. In this chapter, the news articles on rape are regarded as an arena where the discursive field took shape, e.g. by gradually introducing a debate about the alternative terms 'consent' and 'negligence'. The chapter will analyse the process of the legal discourse being gradually influenced by articulations on the discursive field.

\section{The Södertälje case, 1995}

At the time of the Södertälje case, the Swedish rape legislation was a gender-neutral version of the Penal Code (PC) from 1965, implemented in 1984. The offence of rape was regulated as follows:

A person who by violence or threat which involves or appears to the threatened person to involve an imminent danger, forces another person to have sexual intercourse or to engage in a comparable sexual act is guilty of rape [...]. Causing incapacitation or a similar state shall be regarded as equivalent to violence.

(SFS, 1984:399, PC, Chapter 6, Section 1)

In this section of law, the terms 'forces', 'violence', 'threat' and 'causing incapacitation' appeared as nodal points for how the offence of rape was to be defined.

The offence of sexual exploitation is also relevant and was laid down in law as follows:

A person who induces another person to engage in a sexual act by gross abuse of his or her dependent state or by improperly taking advantage of the fact that the he or she is helpless or in some other state of incapacitation $[\ldots]$ is guilty of sexual exploitation.

(SFS, 1984:399, PC, Chapter 6, Section 3) 
The term 'taking advantage' and the wording 'helpless or in some other state of incapacitation' here appear as nodal points in the legal discourse. At this point, it is relevant to note the distinction between causing incapacitation (prerequisite for the offence of rape) and exploiting someone who is helpless or already in some other state of incapacitation (prerequisite for the offence of sexual exploitation). It was in this specific legal context that the Södertälje rape was committed.

In July 1995, an 18-year-old woman, called Anna by the media, was at a restaurant in Södertälje. She was very intoxicated. A 22-year-old man offered her a lift home to the smaller town outside Södertälje where she lived. Once inside the car, she discovered three other young men. Three of the men had repeated sexual intercourse with the woman in the car. Thereafter they took her to an apartment where further vaginal and oral sexual intercourse was carried out. They then promised to take the woman home but, on the way, they stopped the car and one of the men again demanded that she have intercourse with him. The woman, who at this point had sobered up, then bit him in the throat. After this the woman was left and was able to call her step-father to be picked up. ${ }^{2}$

Almost two years later, Södertälje District Court, the lowest court in Sweden, sentenced three of the men to imprisonment for sexual exploitation because they, according to the newspaper Expressen, 'had exploited the girl who, due to her severe intoxication, had been helpless' (24/4 1997). Another newspaper, Aftonbladet, highlighted the term helpless and further developed the description of what this condition means: "[The court] was of the opinion that Anna was completely helpless. She was very intoxicated, she was petrified, she was alone' (24/4 1997). The term helpless was here defined in the everyday sense of the word in terms of feelings 'Anna' experienced. Being helpless meant feeling petrified and alone.

Despite the prosecutor choosing to classify the offence as sexual exploitation rather than rape, the judgement does not seem to have made visible any discrepancy between the legal interpretation of the assault and the general conception of justice. However, the word the newspapers borrowed from the judgement to describe Anna's fear was not the colloquial 'helpless' but the legal term 'helpless state' - one of the nodal points in the legal discourse. In this discourse, the colloquial term's potentially ambiguous meaning was presumed to be fixed in an unambiguous manner - not dependent on 'Anna's' subjective experiences. It would later become evident that the disagreement about the definition of the term helpless state revealed the inherent contingency of the legal discourse and thereby created scope for a struggle for precedence of interpretation.

An appeal against the judgement in the Södertälje case was made to the higher court, the Svea Court of Appeal, which acquitted the three men. The newspaper Dagens Nyheter (DN) reported the Senior Judge of Appeal's explanation in which a distinction was made between the legal nodal point helpless state and the colloquial word helpless: 'The girl was not in a helpless state. Nor 
was she in a state of incapacitation. She could both walk and talk. The section that concerns sexual exploitation is there to protect people who are unconscious or passed out' (DN, 30/4 1997a). This then was another definition of the word helpless - to be unconscious or passed out. In the legal discourse, being able to 'walk and talk' was the same as not being in a helpless state. The court of appeal's narrowing of the definition, which resulted in an acquittal, can be seen as an attempt to fixate the legal discourse by excluding the alternative interpretations.

In the discrepancy between the court of appeal's definition and that of the media, a dilemma arose. Could it really be possible to do what the three men had done and walk free? (DN, 30/4 1997a)

Neither the court nor now [the senior judge of appeal] discuss the possibility that an even moderately intoxicated girl weighing $45 \mathrm{~kg}$ may have felt completely helpless against three men, particularly considering that she said she had been very afraid of them. What ability could she have had to fight off the three with any success?

(DN, 6/5 1997)

The newspaper here sought an interpretation of the term helpless state as both a subjective experience (that she had 'felt helpless') and a physical fact (her weight in relation to the number of men). The wording can be seen as a critique of the fact that the legal definition of the term helpless state is not consistent with the general conception of justice. It was asserted in an opinion piece that 'the perpetrators had been acquitted, not because the court was convinced of their innocence, but because the lawyers, through their sacred law, have turned the reality of what happened into something only they can understand!' (DN, 30/4 1997b). The hegemony of the legal discourse was questioned here by talking sarcastically about the 'sacred law'.

The Senior Judge of Appeal responded to this criticism by stressing that the men may have committed an offence other than sexual exploitation, implying rape, but that this had not been examined in the court of appeal as the prosecution only pertained to sexual exploitation (Svenska Dagbladet, SvD, 3/5 1997). This statement caused some debaters to instead direct their criticism at the public prosecutor's decision not to prosecute the men for rape:

It is obvious that the prosecutor made a misjudgement when he declared himself satisfied with the alternative classification of the offence as sexual exploitation in eight of the nine assaults. In the appeal, the prosecutor should have maintained that rape had taken place in these cases as well.

(SvD, 4/5 1997)

The prosecutor regretted this but revealed his justification: 'I knew that I would have problems proving that there had been violence or the threat of violence. That is why I assessed there to be more chance of them being convicted of sexual exploitation' (DN, 30/4, 1997a). The prosecutor here portrayed the 
choice of how to classify the offence as tactical in order to achieve any kind of conviction. In another article, the prosecutor said it was a problem that the offences rape and sexual exploitation function as each other's opposites so that cases like this 'fall between the cracks' (Expressen, 24/4 1997). With this statement, the prosecutor revealed that he did not necessarily comply with the legal understanding of what constitutes rape, which gave the media legitimacy in their critique of the judgement.

It is the task of the highest court in Sweden, the Supreme Court, to clear up this type of uncertainty around how the law is to be interpreted - to fixate the legal discourse - by establishing certainty and clarity through its judgements. The Supreme Court can be seen as the actor that, in addition to the legislature, formulates the content of the legal discourse by literally having precedence of interpretation. In the Södertälje case, the Supreme Court decided to concur with the district court and convict the men of sexual exploitation by, in the words of the news service Tidningarnas Telegrambyra (TT), 'broadening the term "helpless state"" (TT 10/9, 1997). The Prosecutor-General, who lead the prosecution, opened up the possibility of including a more empathetic assessment of what it means to be helpless in the legal discourse:

The court of appeal made it too easy for itself when it dismissed the potential to interpret what the law means by helpless state. Anna was intoxicated and surrounded by seven men, entirely unknown to her, in unknown locations. She was extremely vulnerable and thus in a helpless state.

(DN, 25/8 1997)

Here further examples were given of what it could mean to be helpless being 'vulnerable' to 'unknown men' in 'unknown' locations. Through the Supreme Court's precedence of interpretation, the meaning of the term helpless was fixated and it was determined that a 'broadened term' would apply.

However, the Södertälje case also initiated a discussion about the need to amend the sexual offences legislation. Even prior to the Supreme Court judgement, the then minister of justice, Laila Freivalds, criticised the justice system and threatened to amend the legislation if the judgement was not the one she favoured: 'If the Supreme Court decision was to indicate the criminal law has shortcomings in terms of the protection it provides against sexual assault, I will not hesitate to immediately ensure that those shortcomings are rectified' (SvD 30/5 1997). Another actor, the legislature, thus stepped into the discursive field. From the legislature's perspective, it is, in order to encourage compliance with the law, key that the wording of legislation and its application are closely aligned with the general public's conception of justice. Ahead of the Supreme Court hearings, there were seemingly two possible outcomes, a judgement that set precedent consistent with the general conception of justice or a change of the wording of the law. 
The Prosecutor-General indicated which direction she thought the legal discourse should take when she described how the conviction opened up the possibility of

perpetrators being convicted even if the victim is passive. It is incumbent upon the man to realise the woman's situation, even if she does not express her fear or try to get away. If a woman is intoxicated the man must realise that she is perhaps not able to make adequate assessments.

(Göteborgs-Posten, GP, 9/9 1997)

This articulation opened up the possibility of placing the responsibility for the situation on the person who performed the sexual act; that which in the sexual offences legislation of 2018 would come to be laid down in a negligence requirement.

The term consent was also mentioned in relation to the conviction in the Supreme Court. Expressen predicted that

the judgment would have several positive effects. It will become easier for prosecutors to bring prosecutions in similar cases. The responsibility is transferred back from women to men, who must ensure that both or all parties have given their consent prior to having sex. [...] It is a partially new but entirely reasonable interpretation of the term 'helpless state'.

(Expressen, 11/9 1997)

The conviction thus opened for a discursive potential to connect consent and negligence to rape and sexual exploitation. This set out two alternative nodal points to force and helpless state.

Following the judgement, Freivalds said that it was a step in the right direction but that uncertainties remained 'within the area of sexual offences'. She announced that a government committee of inquiry would be appointed to 'clarify the terms' (TT, 10/9 1997). The terms of reference for the committee, called 1998 års Sexualbrottskommitté [the Sexual Offences Committee of 1998], stated that the alternative nodal point consent was to be investigated. The committee was to explicitly examine whether the requirements for violence, threat or a state of incapacitation could be replaced by a 'consent construction' (Leijonhufvud, 2015:44).

\section{The Tumba case, 2003}

A few years later, in 2001, the Sexual Offences Committee presented its report in which the matter of consent had been investigated. This report pointed out that the requirement for force could undeniably be seen as an obstacle to taking legal action against what 'rightfully should be punishable acts' (SOU, 2001:14, pp. 89f.). However, the committee did not go all the way and propose consent-based legislation, choosing instead to retain violence, threat or a state of incapacitation as prerequisites for the offence of rape. 
One of the arguments was that a prerequisite of consent risked leading to a 'reversed burden of proof', meaning that it was up to the man to prove that the woman had consented and not the other way around. A consent regulation was thus deemed to challenge another of the legal discourse's central nodal points - the principle of on whom the burden of proof lay (SOU, 2001:14, p. 128). This left the terms consent and negligence hanging in the air, while the terms violence, force and incapacitation were once again fixated as nodal points in the legal discourse through having been given new political legitimacy.

Nonetheless, other legislative changes were proposed, for example that the prerequisite for sexual exploitation, exploiting someone who is already 'helpless or in some other state of incapacitation', should be moved to the section on rape. I will return to this, but because the amendment did not happen until 2005 , the legal situation was unchanged at the time of the 'Tumba case'. 3

In February 2003, a 32-year-old mother of two was at a bar in Tumba, a Suburb outside Stockholm, together with a female friend. She met three younger men that she knew superficially. The party left the bar together and the men gave the woman a ride home. After that point, the woman has no memory and she suspected that she had been drugged, however this could not be proven. Once in the woman's apartment, the men carried out repeated oral and vaginal intercourse with the woman, sometimes several men at the same time. Further men came to the apartment, and a total of seven different men were suspected of having had intercourse with the woman over several hours. Between the instances of intercourse, the woman walked around the apartment, intoxicated and naked, smeared in semen.

Four men were prosecuted in Huddinge District Court for sexual exploitation. The media appeared to have learned the legal terminology after the Södertälje case and explained: 'The fact that the offence is classified as sexual exploitation is because the woman, by drinking alcohol, has contributed to being in what is called a "helpless state" (TT, 9/4 2003). The choice to legitimise in this instructive manner the court's classification of the offence suggests the hegemony of the legal discourse. However, the fact that there is any need to explain the court's definition reveals that this is obviously defined as rape outside of the legal discourse. In other words, the wording makes it clear that there was a discrepancy between the general conception of justice and the law.

As if to anticipate the criticism of the charges brought that was directed at the prosecutor in the Södertälje case, the public prosecutor admitted in Aftonbladet that 'because rape in colloquial terms is to have sex with someone who doesn't want to, I can see how it seems a bit odd that we lawyers classify it differently' (17/4 2003). The prosecutor here presumed that the general public, as opposed to the lawyers, had a perspective on rape that did not assume force, meaning instead a lack of consent.

Both Huddinge District Court and the Svea Court of Appeal acquitted the four men with the argument that the woman had not been in a helpless state. The judgements sparked strong reactions in the newspapers' editorial and 
opinion pages. 'A lone woman against four men, how is she supposed to defend herself regardless of whether she is sober or not? Can you be any more helpless than that?' (GP 29/4 2003). 'Blind drunk women are every man's property in Sweden. The court of appeal judgment in the Tumba group rape trial cannot be interpreted in any other way' (GP 5/11 2003). The criminal law professor Madeleine Leijonhufvud, who would become a leader in the political struggle for consent-based legislation, warned in Aftonbladet of what could happen unless there was change in how the law is applied: 'I see great, great anger emerging, not least among young women. [...] They are becoming a strong political force that are forcing a change to the law so that it actually protects them' (7/11 2003).

In addition to the term helpless state, the news reporting pinpointed another nodal point in the legal discourse that had not been discussed in the Södertälje case, that rape is a crime committed with intent. For a sexual act to be an offence, the perpetrator must be aware that the act is committed using force but chooses to carry on regardless. The district court's justification for the acquittal, as it was reported in the media, questioned whether there was intent:

The woman [had] voluntarily gone with the men in the car to the apartment. One of them had previously danced with her at a restaurant. She had reportedly behaved in a sexy manner. According to herself, she can be perceived as flirty. She was happy and giggly when she left the restaurant. 'Even though it may be difficult to understand how anyone voluntarily wants to be part of such activities as occurred in the apartment, this behaviour - from the men's point of view - cannot be considered so unnatural that it is proven that they had exploited the state she was in', the court writes.

$D N$ 's response to the acquittal in the court of appeal suggested that this hypothesis was perceived as ridiculous:

The woman was helpless when she was sexually exploited by several men. But they didn't understand that she was helpless because she was active. That was the court of appeal's reasoning when it acquitted four men in the much-discussed Tumba case.

The leader writer Maria Carlshamre described how the requirement for intent, combined with the lack of both a consent and a negligence prerequisite, deprived women of their rights:

Swedish legislation has an implied prerequisite: women are basically available for sexual intercourse - unless otherwise specified. On the other hand, men are not being held responsible for finding out whether women consent to 
intercourse. And if a woman finds herself in a helpless state, it is sufficient for the men to be too dumb to realise that for them to walk completely free.

(DN 4/11 2003)

This summed up what was perceived to be the problem with the nodal points that constituted the legal discourse on rape at that time - that in the legislation and in practice women were, as a rule, available and men were relieved of responsibility (cf. Andersson, 2004). At the same time, the possibility of an alternative legal discourse was articulated, one that was based not on force and intent but on consent and responsibility in a way that is similar to the sexual offences legislation of 2018.

The debate came to encompass the change to the legislation that had been announced in the debate concerning the Södertälje rape. As mentioned above, the Sexual Offences Committee of 1998 had presented its report in 2001 (SOU, 2001:14), but by 2003, no legislative change had been proposed. In the debate about the Tumba case, the social democrat government, represented by the new Minister of Justice Tomas Bodström, took the opportunity to launch the forthcoming proposal.

The question of whether it shall be possible to classify an assault as rape when a severely intoxicated woman is sexually exploited is one of the questions the Ministry of Justice is currently wrestling with. A new proposal will be presented before the end of the year [...]. Under this proposal, sexual assaults against severely intoxicated, sleeping or disabled people will in future be classified as rape.

$(\mathrm{SvD}, 14 / 10$ 2003)

It was evident here that the government had seized on the problem that in neither the Södertälje case nor the Tumba case had the prosecutor considered themselves able to prosecute for rape, choosing instead to classify the offences as sexual exploitation. Under this proposal, the solution was to allow more experiences of assault to be classified as rape. Some described the forthcoming legislative amendment as a solution to the legal dilemma. 'If this proposed new law had applied, the men would have been prosecuted for rape, not sexual exploitation' (Sydsvenskan, 5/11 2003).

However, many debaters were not satisfied. Instead, the demand for a consent prerequisite was again brought to the fore. "Amend the law so that the woman's consent it required!" is the new battle cry from all of those who have already tired of Bodström's legislative amendment before it has even come into force' reported Anna Dahlberg, leader writer at Expressen (20/11 2003).

In modern sexual offences legislation, the starting point must be that the person who wants to have sex is responsible for establishing whether this desire is reciprocated. The woman's duty to resist should be replaced by 
the man's duty to ensure there is consent wrote $D N$ 's leader writer Maria Carlshamre (4/11 2003).

However, in his response to the newspapers' critique, Bodström made it clear that the new law would not contain a consent prerequisite: 'Minister of Justice Bodström has finished considering this point: he says that if we reverse the burden of proof, Sweden risks ending up in the European Court of Justice' (GP, 6/11 2003). It became clear at this point that the legislature not only had the political duty to listen to the general public but was also forced to align with the legal discourse. Arguing that Sweden risked ending up in the European Court of Justice if the legislation was brought closer in line with the general conception of justice, Bodström clearly marked the boundaries of what changes to the legal discourse were possible. Rhetorically choosing to describe consentbased legislation - a format for the legislation that had already been applied in several countries - as a violation of one of the most important principles of the legal discourse - to 'reverse the burden of proof' - further legitimised the legislature's decision on this issue. Stating that he had 'finished considering this point' created a fixation of the legal discourse.

Despite the announcement that new legislation, which, if it had been in force when the Tumba case happened, could have resulted in a rape conviction, was on the way, the case was brought before the Supreme Court. This was interpreted by some to mean that the articulations of the discursive field had literally infiltrated the legal discourse. Expressen wrote that 'the lawyers for the accused claim that the Prosecutor-General had given in to popular opinion and that is why the case had been brought before the Supreme Court' (30/3 2004).

However, the actual reason why the case was brought was to examine the issue of intent. The Prosecutor-General said that:

It involves, among other things, making it clear what responsibility can be demanded of the suspects, of the three men in this case. If it is as the men say, that she was the instigator, it is still not OK to just go ahead. You may not take advantage of someone who is in no fit state to realise what she is offering.

(SvD, 31/3 2004)

In the Tumba case, just like in the Södertälje case, the Prosecutor-General opened up the possibility of a more empathetic approach to the victim's situation to be included in the legal discourse; in the quote, it is worded in a way that is reminiscent of the reasoning concerning negligence in the legislation of 2018.

Nevertheless, this approach was absent when the Supreme Court also chose to acquit the men. According to the media reporting, the argument was instead based once more on the fact that the women had not been in a helpless state:

There is no doubt that she was drunk and had lost her sense of judgement. However, this doesn't mean that she was in a helpless state of the 


\section{Gabriella Nilsson}

kind the law defines as grounds for it being an offence to have sexual relations with her.

(Aftonbladet, 5/5 2004a)

The legal vacuum between rape and sexual exploitation was again highlighted in the editorial pages of both Aftonbladet and Expressen: 'Either you have been forced to have sex or you have been so passed out that you have not been able to notice any sexual advances whatsoever. In between those situations, nothing criminal has occurred' (Expressen, 5/5 2004). 'In a legal sense, it is not possible to convict the men. In principle, this proves that the law, as it is currently worded, is based on a degrading view of mankind' (Aftonbladet, 5/5 2004b). It is 'a hard day for Swedish gender equality' is how Expressens leader writer Anna Dahlberg summed up the situation (5/5 2004).

\section{The Husby rape, 2006}

The new sexual offences legislation came into force on 1 April 2005 (Govt. Bill, 2004/05:45). The change that had the greatest relevance for the cases analysed here was the second paragraph of the section on rape where it was stipulated that someone could be convicted of rape who, in addition to violence and threat, performs sexual intercourse or a sexual act with a person:

[...] by unlawfully exploiting the fact that this person, due to being unconscious, asleep, intoxicated or under the influence of drugs in some other way, ill, injured or having some form of mental disorder, or, taking into account the circumstances, is otherwise in a helpless state.

(SFS, 2005:90, PC, Chapter 6, Section 1)

Here, the prerequisite for sexual exploitation - exploiting someone who already was in a helpless state - had been included in the prerequisite for the offence of rape and had also been specified through a list of possible situations in which a helpless state could exist. This change would make it possible to avoid the dilemma the prosecutors faced in both the Södertälje case and the Tumba case - the difficulty of prosecuting for rape. It was in this legal context that the Husby case occurred.

The night of the 14 May 2006, a 25-year-old woman visited a disco in central Stockholm. She drank alcohol and felt nauseous, which is why she chose to leave the place. On her way home, she met three unknown men who took her with them in an unlicensed taxi. The woman was taken to an apartment in Husby, a Suburb to Stockholm. Once there she has vague memories of two men having intercourse with her. In the morning, the woman is thrown out of the apartment and is encouraged by a friend to report the incident to the police. 
The Husby case was the first group rape case with media attention that would be tried under the new legislation. The prosecutor argued that the men had exploited the woman's helpless state and chose to prosecute them for aggravated rape. $S v D$ reminded the readers of why it was now possible to charge the men with rape: 'Under the new sexual offences legislation from 2005, sexual assaults against victims who are severely intoxicated are to be classified as rape rather than sexual exploitation' (25/10 2006). However, despite the amended legislation, Stockholm District Court acquitted the men. 'Difficulty with proof despite the new law' was the headline in Aftonbladet following the judgement (23/11 2006).

Again, it was the definition of the term helpless state that was the problem: "According to the district court, it is not possible to conclude that the woman was in a helpless state and there are therefore no grounds on which to examine whether she was the victim of rape' (Expressen, 22/11 2006). The acquittal showed that, more than ten years after the Supreme Court set the precedent that a helpless state could mean 'being vulnerable to unknown men in unknown locations' in its judgement in the Södertälje case, the legal discourse could still use the level of intoxication as a measurement of helpless state.

The victim's lawyer expressed her surprise at the judgement, according to the newspaper Metro:

Even though there is new sexual offences legislation that is supposed to protect victims of crime who are under the influence of alcohol and drugs, we are stuck in a situation where assessments are being made under the old legislation. If we don't change our viewpoint, we'll never be able to take legal action against this type of men's violence against women.

With this statement, the lawyer gave legal legitimacy to the new law and instead directed her criticism inwards, towards the actors within the legal discourse and their inability to read the new law in the way the legislature intended.

It is conceivable that the district court judgement in the Husby case was perceived as problematic by the government that had pushed the legislation through and put their faith in it working. Thus, it might have been a relief when the Svea Court of Appeal sentenced the men to imprisonment for rape when the judgement in the Husby case was appealed against the following year. Aftonbladet wrote that

The court of appeal is of the opinion, in contrast to the district court, that it is beyond reasonable doubt that the men have raped the now 27-year-old woman. According to the court of appeal, the men have exploited the woman's helpless state and they were also well aware of this. 


\section{Gabriella Nilsson}

The judgement confirmed that the men had exploited the woman and that they did this with intent. In that respect, the judgement can be seen as a defence of the new legislation and as a reflection of the fact that the legal discourse and the general conception of justice were in accord.

\section{The Tensta rape, 2013}

After the Husby rape, the sexual offences legislation was however still debated. The government therefore decided to set up a special inquiry, the 2008 Sexual Offences Inquiry, tasked with evaluating the application of the 2005 sexual offences reform. This assignment included once more investigating and determining whether the current requirement for force as a basis for criminal liability for rape should be replaced with a requirement for a lack of consent.

In its report, the inquiry argued that even though the protection of personal and sexual integrity as well as sexual self-determination had been reinforced through the new legislation, the term helpless state was considered too limited to cover all acts where the perpetrator had exploited the situation the victim was in (SOU, 2010:71). Following this inquiry, the government however once again made the assessment that the disadvantages that a consent regulation would entail were not outweighed by the advantages (Leijonhufvud, 2015, p. 75). Instead, the result of the inquiry was that the government proposed a minor amendment to the second paragraph of the rape section, which meant that the term helpless state was replaced with the broader term 'particularly vulnerable situation' (Govt. Bill, 2012/13:111). The legislature argued that, by doing so, several of the acquittals covered heavily in the media could be avoided in future. However, before the change came into force on 1 July 2013, the Tensta case occurred.

On 2 March 2013, a 15-year-old girl went with two female friends to the Stockholm suburb of Tensta to attend a private party. In the apartment were eight similarly aged boys who the girl did not know. Later on, when one of the friends had gone home and the other was very intoxicated, the girl was in a bedroom where she had intercourse with one of the boys. Subsequently a situation occurred where five other boys lined up to have intercourse with the girl. The girl said that she did not want to, but the boys repeatedly had intercourse with her. They had taken her jacket and phone and at times the room was locked. When the boys were finished, the girl left the apartment and reported the incident to the police.

In June 2013, Solna District Court found five boys guilty of aggravated rape. 'In legal terms, the girl was in a helpless state. She was outnumbered, she did not know the boys, they were obtrusive, and she was afraid of them beating her up if she did not do as they said' (TT 14/6, 2013). TT's reporting of the judgement indicates that the district court appears to have used the broader definition of helpless state that had been applied by the Supreme Court in its assessment 
of the Södertälje case. Helpless state was described as being possible to define as a subjective experience of fear, and not directly related to the level of intoxication not just in the general conception of justice but also in legal terms.

However, the judgement was appealed and the Svea Court of Appeal acquitted the boys in September 2013. The judge explained to Aftonbladet that 'the intercourse that took place could very likely have occurred against her expressed will, but if it is not exploitation of a helpless state, it is not rape' (28/9 2013). The court of appeal judge here defended the acquittal by reminding us that the new legislation was not based on a consent prerequisite intercourse that took place against someone's will was not by definition illegal. However, critics argued that the judgement did not pertain to deficiencies in the legislation, rather to lawyers' 'male perspective' (Kvällsposten, 5/10 2013).

The fact that the court considers it possible that the boys would not be aware of the imbalance of power in that room and would not be able to understand that the girl was afraid shows a shockingly low faith in boys' ability to be sympathetic and to assess reciprocity.

(Expressen, 27/9 2013a)

This problematises, once again, the term intent and what responsibility should be demanded of the person who actively carried out the sexual act.

Between the conviction in the district court and the acquittal in the court of appeal, the amendment from helpless state to particularly vulnerable situation had entered into force, which is why the reporting of the Tensta case came, to some extent, to be characterised by a sense of hope for the future. 'You can read between the lines of the court of appeal's grounds for the judgement that if it had been possible to apply the new law, they would have been convicted' (Expressen, 27/9 2013b). However, the acquittal was not just debated in terms of hope, the debate was also suffused with a resignation to the fact that the legislation always seemed to be one step behind reality; that the legislature acted reactively rather than proactively. Expressen's Maria Rydhagen wrote that 'when it comes to rape, the law is like a tone-deaf drunk [...]. I think few Swedes support or even understand the Svea Court of Appeal judgement that was announced yesterday' (28/9 2013). Instead, the judgement gave rise to new demands for consent-based regulation:

One proposal that has been brought up again is a requirement for consent for sex. [...] After this judgment in the Svea Court of Appeal, this proposal should be properly examined. In a democracy, courts cannot in the long run go against people's sense of justice.

(Aftonbladet, 1/10 2013)

Evidently, as the legal discourse had failed time and again to achieve convictions in cases that seemed clear-cut in the general conception of justice, its hegemony was weakened and alternative nodal points such as consent appeared 
increasingly attractive, even among members of parliament. There was now a political 'breeding ground' for a change towards consent-based legislation (Expressen, 6/10 2013).

On 28 August 2014, the government decided to set up a special inquiry with the task of once again reviewing the offence of rape, an inquiry that was later reorganised into the 2014 Sexual Offences Committee. Two years later, on October 2016, the Committee recommended a consent-based legislation (SOU, 2016:16). After a long period of referral for consideration and comment, the government bill was presented in parliament, which was adopted on 23 May 2018. Consent-based legislation entered into force in Sweden on 1 July 2018.

\section{Conclusion}

I have shown how the amendment to the sexual offences legislation in 2018 is the result of a discursive process in which the terms 'consent' and 'negligence' have been gradually introduced, heavily debated and slowly implemented in the legal discourse over a period of more than twenty years. Theoretically, I have shown how the legal shift from a force-based legislation to a consent-based construction is the result of an ongoing interplay between challenging articulations on the discursive field and attempts to fixate the meaning of terms on the legal discourse. By definition, continuous attempts to fixate nodal points is what constitutes a discourse (Laclau \& Mouffe, 1985).

Although a consent-based legislation has come into force in other countries far earlier than in Sweden, this has not been utilised in the Swedish debate, neither as an argument for nor against such a legal construction. Instead, the aim of this chapter has been to show that the discursive field where this legal process took shape has been the news reports and debate about a number of hyper-medialised Swedish group rape cases. News reports and debate about these cases have formed the arena where the voices of the law have been both defending the legal discourse and highlighting its dilemmas, such as the various potential meanings of 'helpless state' and the crack between the offences rape and sexual exploitation. The cases have also formed the arena where representatives of the legislator have attempted to meet the demands for a change expressed in the public opinion and bridge the discrepancy between the general conception of justice and the law.

It is clear that in Sweden, the appointment of government committees of inquiry plays a crucial part in the development and implementation of political reform. In fact, Swedish historian Sara Edenheim has shown that appointing a committee might be of greater political value than to actually implementing its recommended change (2005). However, news media is central in this political process, and specifically the news reports about group rape cases have offered a sufficiently turbulent situation for the challenging articulations on the discursive field to have an impact (cf. Nilsson, 2018). The news reports of the legal discourse failing time and again to achieve convictions in cases that seemed clear-cut in the general conception of justice weakened its hegemony and gradually made the alternative nodal point consent appear increasingly 
attractive, even among members of parliament. With the new legislation that entered in force in July 2018 (SFS 2018:618), it remains to be seen how the various potential meanings of consent, or voluntariness, and liability for negligence will be interpreted.

\section{Notes}

1 All quotes from newspaper articles have been translated from Swedish by the author.

2 All summaries are made by the author and are based on the information given about the cases in the news.

3 The law was unchanged apart from a minor amendment that was adopted as part of the Kvinnofridspropositionen [the Women's Peace Bill] (Govt. Bill, 1997/98:55).

\section{References}

Aftonbladet 24/4 1997. Rätten friade gruppvåldtäkt. News article, unsigned.

Aftonbladet 17/4 2003. Åtalade för grovt sexbrott. Släpps i väntan på dom. News article, Cecilia Gustavsson.

Aftonbladet 23/11 2006. Tre går fria från gruppvåldtäkt. Bevissvårigheter trots nya lagen. News article, unsigned.

Aftonbladet 7/11 2003. Dags att förbjuda alla sexuella övergrep. Debate article, Madeleine Leijonhufvud.

Andersson, Ulrika, 2004. Hans (ord) eller hennes? En könsteoretisk analys av straffrättsligt skydd mot sexuella övergrepp. Lund: Bokbox Förlag.

Aftonbladet 5/5 2004a. 'Jag ångrar inte anmälan'. News article, Cecilia Gustavsson.

Aftonbladet 5/5 2004b. Ändra lagen om sexbrott. Unsigned editorial.

Aftonbladet 5/10 2007. Friade för våldtäkt fällda i hovrätten. News article, unsigned.

Aftonbladet 1/10 2013. Våldtäkt borde inte vara lagligt. Editorial, Anders Lindberg.

Aftonbladet 28/9 2013. Domaren: Hon kan mycket väl ha sagt nej. News article, Anders Clark.

Aftonbladet 17/12 2017. Regeringen inför samtyckeslag - sex ska vara frivilligt. News article.

Andersson, Ulrika, Edgren, Monika, Karlsson, Lenaoch \& Nilsson, Gabriella, 2016. Våldtäkt i Sverige 1990-2013: ett historiskt och intersektionellt perspektiv på berättelser om våldtäkt i olika genrer. Gränsløs. Tidskrift för studier av Öresundsregionens historia, kultur och samhällsliv, 6: 82-92.

Bumiller, Kristin, 2008. In an abusive state. How neoliberalism appropriated the feminist movement against sexual violence. Durrham: Duke University Press.

Dagens Nyheter 25/8 1997. Hjälplös nog att bli utnyttjad? Södertäljemålet i HD. News article, Ulrika By.

Dagens Nyheter 6/5 1997. Den friande domens försvar. Unsigned editorial.

Dagens Nyheter 30/4 1997a. Södertäljemålet: Sexdom kan bli fall för HD. News article, Ulrika By.

Dagens Nyheter 30/4 1997b. Driv Södertäljemålet till HD. Nu måste det klargöras vad en våldtäkt egentligen är. Debate article, Billy Butt och Annika Hjelmqvist.

Dagens Nyheter 2/12 2003. Tumbadomen prövas av HD. News article, Peter Letmark.

Dagens Nyheter 4/11 2003. Dags att förändra våldtäktslagen. Editorial, Maria Carlshamre. 


\section{Gabriella Nilsson}

Edenheim, Sara, 2005. Begärets lagar. Moderna statliga utredningar och heteronormativitetens genealogi. Stockholm/Stehag: Brutus Östlings Bokförlag Symposion.

Expressen 11/9 1997. Hjältinnan. Unsigned editorial.

Expressen 24/4 1997. De måste straffas. News article, Challe Lundholm.

Expressen 20/11 2003. Var är juristerna? Editorial, Anna Dahlberg.

Expressen 30/3 2004. Sexoffrets sista chans. News article, unsigned.

Expressen 5/5 2004. De tror inte på kvinnan. HD friar männen från övergrepp vid gruppsex. Editorial, Anna Dahlberg.

Expressen 22/11 2006. Frias från gruppvåldtäkt i Husby. News article, unsigned.

Expressen 6/10 2013. Nät-ilska kan hjälpa. Experten: 'På lång sikt påverkas politikerna och lagstiftningen'. News article, Karl-Johan Karlsson.

Expressen 28/9 2013. Juridik och moral är olika saker när de gäller våldtäkt. Editorial, Maria Rydhagen.

Expressen 27/9 2013a. Alhem: Med den nya lagen hade de fällts. News article, Stina Loman.

Expressen 27/9 2013b. Frias för gruppvåldtäkt - rummet var för mörkt, News article. Rebecka Martikainen

Göteborgs-Posten 9/9 1997. Vilken väg väljer rätten? Imorgon avgör Högsta domstolen Södertäljefallet. News article, Eva Parkrud.

Göteborgs-Posten 29/4 2003. En kvinna är hjälplös mot fyra män! Editorial, Carina Andersson.

Göteborgs-Posten 5/11 2003. Kvinnan rättslös snarare än fredad. Unsigned editorial.

Göteborgs-Posten 6/11 2003. Skärpta sexlagar nästa år. News article, Björn Svensson.

Govt. Bill 1997/98:55. Kvinnofrid. Regeringens proposition.

Govt. Bill 2004/05:45. En ny sexualbrottslagstiftning. Regeringens proposition.

Govt. Bill 2012/13:111. En skärpt sexualbrottslagstiftning. Regeringens proposition.

Govt. Bill 2017/18:177. En ny sexualbrottslagstiftning byggd på frivillighet. Regeringens proposition.

Kvällsposten 5/10 2013. 'Domen är felaktig' - Sven-Erik Alhem sågar hovrätten i våldtäktsmålet? News article, Eva Rogsten.

Laclau, Ernesto \& Mouffe, Chantalle, 1985. Hegemony and socialist strategy. Towards a radical democratic politics. London and New York: Verso.

Leijonhufvud, Madeleine, 2015. Svensk sexualbrottslag. En framåtsyftande tillbakablick. Stockholm: Norstedts juridik.

McGlynn, Clare \& Munroe, Vanessa E. (eds), 2010. Rethinking rape law: International and comparative perspectives. Oxford and New York: Routledge.

Metro 24/11 2006. Nu förstår jag varför flickor inte anmäler. News article, Anna Hagman.

Nilsson, Gabriella., 2018. Rape in the news: On rape genres in Swedish news coverage. Feminist Media Studies. Published online. https://doi.org/10.1080/14680777.2018.1513412

SFS 1984:399, BrB kap. $61 \S, 3 \S$.

SFS 2005:90, BrB kap. $61 \S$.

SFS 2018:618, BrB kap. $61 \S$.

SOU 2001:14. Sexualbrotten - Ett ökat skydd för den sexuella integriteten och angränsande frågor. Betänkande av 1998 års Sexualbrottskommitté.

SOU 2010:71. Sexualbrottslagstiftningen - utvärderingen och reformförslag. Betänkande av 2008 års sexualbrottsutredning.

SOU 2016:60. Ett starkare skydd för den sexuella integriteten. Betänkande av 2014 års sexualbrottskommitté. 
Spohn, Cassia \& Horney, Julie, 2013. Rape law reform: A grassroots revolution and its impact. New York: Plenum Press.

Svenska Dagbladet 3/5 1997. Svea hovrätt hade inga andra möjligheter än att fria. Debate article, Peter Löfmarck.

Svenska Dagbladet 30/5 1997. Våldtäktsmål kan leda till skärpt lag. News article, Bosse Brink.

Svenska Dagbladet 4/5 1997. Juridiska missar om våldtäkt. Unsigned editorial.

Sydsvenskan 5/11 2003. Prövning i HD inte trolig. News article, Bibi Häggström.

Svenska Dagbladet 14/10 2003. Kritiserat domslut i sexmål prövas igen. News article, Daniel Kjellberg.

Svenska Dagbladet 31/3 2004. Uppsåt avgör dom i Tumbamålet. News article, unsigned.

Svenska Dagbladet 25/10 2006. Tre åtalas för våldtäkt av berusad ung kvinna. News article, Christina Wahldén

TT 10/9 1997. HD dömer tre män för våldtäkt och sexövergrepp på 18-årig. News telegram.

TT 25/4 2003. Fyra frikända i gruppsexmål. News telegram.

TT 9/4 2003. Fyra män åtalade för sexövergrepp på kvinna. News telegram.

TT 14/6 2013. Tveklös dom om gruppvåldtäkt. News telegram.

Wennstam, Katarina, 2002. Flickan och skulden: en bok om samhällets syn på våldtäkt. Stockholm: Bonnier. 


\title{
8 Rape law and coercive circumstances
}

\author{
Helena Jokila and Johanna Niemi
}

\section{Introduction}

Rape law has undergone several changes since the second-wave feminist movement placed such legislation on the agenda in the 1970s (Brownmiller, 1974/ 1993; Estrich, 1987). One central debate has been whether lack of consent or use of force should be considered the basic element of rape (MacKinnon, 1996, 2006; McGlynn \& Munro, 2010). Broadly speaking, the European continental countries have historically relied on (and still rely on) use of force in their definitions of rape, while the Anglo-Saxon countries use lack of consent as the central element of rape (European Court of Human Rights [ECtHR] M. C. v Bulgaria, 2003, pp. 156-162; Munro, 2010). Alongside these two legislative strategies, the International Criminal Tribunals for Rwanda and for the Former Yugoslavia (ICTR and ICTY, respectively) have convicted as rape any sex crimes committed under coercive circumstances, under which no consent can be valid. Recent international documents and case law have again emphasised lack of consent as the essential element of rape, and a similar trend has occurred in the Nordic countries.

We argue in this chapter that the differences between the two main legal definitions of rape are more of a technical nature than about the underlying understanding of rape as a type of wrongdoing. We argue that, despite their differences, the two strategies of rape law at a deeper level share the same ontological and epistemological basis and offer insufficient responses to rape under coercive circumstances. At the ontological level, both definitions focus on a certain criminal act and exclude context. In this chapter, we focus on the coercive circumstances of rape and how the courts take such circumstances into account.

Epistemologically, evidence in the courts is connected to physical signs of violation, external observation by witnesses and, increasingly, expert testimony of trauma. The purpose of evidence is to show that the individualised act happened, not to provide evidence of the surrounding circumstances.

Historically, the notion of the context of rape has broadened to show that the victim had behaved in a way that demonstrated consent or lack of resistance by drinking, flirting or her manner of dressing (O'Donovan, 1997, p. 53). In this 
chapter, we look at the context of rape from another perspective. We use the concept of coercive circumstances (taken up by the ICTR and ICTY) and look at the case law of the ECtHR and the Finnish courts to see how they have noted elements of coercive circumstances. First, we briefly present national legislative discourses. While we focus on Finland, we also refer to developments in other Nordic countries and in Canada.

The concept of coercive conditions that the ICTR and ICTY used concerned fairly extreme circumstances. Munro (2010) has argued that the coercivecircumstances element is problematic in national contexts of rape (as opposed to international or armed conflicts). She argues that there is a qualitative difference between rapes in these circumstances. During conflicts, rape is committed in the context of other wrongful acts; the perpetrator and victim do not know each other and belong to antagonistic ethnic or social groups. In peacetime, many rapes are committed between people who are close to each other or know each other, rapes are not always accompanied by other forms of physical violence and threats, and the power relations at play are more complex (Munro, 2010 , p. 24). In addition, replacing consent with the idea of coercive circumstances would undermine women's sexual autonomy (Munro, 2010, p. 26).

In this chapter we investigate what the consideration of coercive circumstances would mean in the adjudication of rape under normal, peacetime circumstances. Our empirical data are drawn from Finnish courts. We focus on cases of rape in intimate partnerships and among youth - both of which illuminate problems in the application of rape law - and analyse what kinds of coercive circumstances are present in these types of rape and how the courts have addressed these circumstances.

\section{Theory, method, and data}

Theoretically, law is a social construction, made in legislative processes and legal practices. Relying on constructionist theory, we argue that facts are also socially constructed during these processes (Berger \& Luckmann, 1966; Burr, 1995). Thus, the courts construct the facts of a given case, and criminal law guides crime-investigation processes and interpretations (Bennet \& Feldman, 1984; Niemi-Kiesiläinen, Honkatukia \& Ruuskanen, 2007).

In criminal-law doctrine, sexual self-determination is the foremost value protected by criminal law on sex crimes. Self-determination is a central aspect of personal autonomy, which is the central tenet of the construction of legal personhood. In legal doctrine, a 'person' is usually understood to be a unified, pre-existing and stable entity who is morally immune to and isolated from the influence of other people. We instead adhere to critical analysis of the legal person and autonomy, according to which personality and autonomy develop during social interactions with other people. Interaction makes the capacity to self-determine possible. We draw on the relational concept of autonomy proposed by several feminist legal theorists (Davies, 2001; Fineman, 2004; Naffine, 2011). 
The relational understanding of autonomy is linked to trust (Lacey, 1998, pp. 62-68; Nedelsky, 1989, p. 11), which can be defined in different ways. Drawing on Govier (1993) and Brothers (1982), we understand trust to be an affective entity and an individual and social experience - as a feeling of being safe with other people. In psychology and feminist philosophy, trust in other people and self-trust are thought of as supporting people's experiences of themselves as autonomous people (Brothers, 1982) and as the precondition for acting as moral people (Govier, 1993).

Psychological studies indicate that a breach of trust in a sexual relationship has unique consequences for victims. A person's self-trust and self-respect can collapse (Brothers, 1982) and can severely shake someone's belief system about the world. The betrayal of trust can destroy the feeling of being safe in the intimate private sphere and of having control over one's life. Victims of sexual violence in intimate relationships typically suffer from the psychological consequences of the crime longer than victims of stranger rape do (Gidycz \& Koss, 1991, p. 279; Katz, 1991, pp. 264-265; Näre, 2000).

In our reading of case law, we are interested in trust: What aspects of the context indicate that a level of trust has existed between the victim and the perpetrator? Do the courts address issues of trust in their decisions?

Today the debates about the elements of rape are international or transnational; we thus refer to discussions in other Nordic countries as the nearest reference points for Finnish legislative processes. Canadian rape law has gone the furthest in requiring affirmative consent for sexual intercourse to proceed. Because most of the pressure to introduce laws that criminalise non-consensual sex has come from international law, we also look at central international documents and cases. Our empirical data consist of published Finnish court decisions on rape (identified through Finlex and Edilex) from 2000 until 2018. In addition, the data include all 98 cases from the Finnish courts of appeal in 1999-2002. From this sample, originally collected by Jokila (2010) for her doctoral thesis, we have analysed cases of intimate partner rape and rape among young people between 16 and 19 years old.

\section{Legal developments}

\section{National laws: from use of force towards lack of consent}

Traditionally, the Nordic countries have relied on a model in which the basic element of rape is use of force or threat of force. This basic definition has been complemented by definitions of rape or sexual abuse that criminalise abuse of a person who is unable to consent or resist because of unconsciousness, illness, disability or similar conditions. Especially after 2004, debates about rape-law reform have shifted towards the lack-of-consent model.

Swedish law included a distinction between rape with the use of force and the sexual abuse of a person who was unable to express resistance until 2018. Between these two sex crimes was an abyss that was debated while several 
cases - referred to by place names such as Jordbro, Rissne, Tumba, Södertälje and Stureplan - were processed through the courts (see Nilsson's chapter in this volume). The facts in these cases had similarities: one victim, usually a young woman, who was intoxicated but not passed out; several men; little to no physical violence; and no evidence of explicit threats and resistance in either words or actions. In some of the cases, the defendants were convicted of rape, while in others the courts dismissed the charges. The central problem was that the victim had not passed out (which would have qualified as sexual abuse), nor was there evidence to show use of force or resistance by the victim (which would have qualified as rape). These cases then fed into a heated debate about the construction of rape (Asp, 2010; Leijonhufvud, 2008). In 2018, the law was changed, and intercourse or a comparable sexual act with someone who does not participate voluntarily is now defined as rape (Brottsbalk 6:1; as amended by law, 2018:618).

Icelandic law has evolved to include both force and lack of consent (Iceland Review, 2018). In Norway, rape is defined as use of force, but the provision of rape with grave negligence mitigates this position, even if this provision is very rarely used. Lack of consent has also been discussed in Norway. Canadian law, which emphasises the victim's consent, requires affirmative consent for sexual intercourse to proceed. The legislation specifically mentions the abuse of trust as an element of rape. Someone who is protected by the criminal provision is constructed as a legal subject who actively and affirmatively utters his or her consent (or non-consent) with words or deeds. Canadian law requires that a person take 'reasonable steps' to find out whether or not a partner is consenting. The use of the defence of 'mistaken belief' regarding the partner's consent is restricted (Gotell, 2010, p. 212). The Canadian model has been called the 'communicative model' of sexuality (Boyle, 1984; Pineau, 1996; critically, Halley, 2016).

Consent is not and has never been a part of the legal definition in Finland. The relevant Finnish legislation defines rape as a violent coercion to engage in sexual intercourse:

A person who forces another into sexual intercourse by the use or threat of violence directed against the person shall be sentenced for rape to imprisonment for at least one year and at most six years. ${ }^{1}$

(Criminal Code [CC] 20:1.1/1999)

Besides the use of force, a rape can be committed by taking advantage of another person's state of unconsciousness, illness, fear or helplessness, all of which make this person incapable of formulating or expressing his or her will to engage in sexual intercourse. ${ }^{2}$ According to the law:

Also a person who, by taking advantage of the fact that another person, due to unconsciousness, illness, disability, state of fear or other state of helplessness, is unable to defend himself or herself or to formulate or 
express his or her will, has sexual intercourse with him or her, shall be sentenced for rape.

(CC 20:1.2/2014/509)

This paragraph was a reformulation of an outdated crime of sexual abuse of an 'unconscious woman'. As a remnant of that previous law, the law still requires the incapability of expressing resistance, but the widening of the scope of vulnerable states brings the law closer to considering coercive circumstances. In addition, the law also includes a less serious form of rape, which can be committed by a less serious threat of force, abuse of a situation of helplessness, or other kind of threat. In such situations, the punishment is meted out on a lower scale:

If the rape, taking into consideration the pettiness of the threat or the other circumstances connected with the offence, is less serious when considered as a whole than the acts referred to in subsections 1 or 2 , the offender shall be sentenced to imprisonment for at least four months and at most four years. A person who forces another into sexual intercourse through other than the threat referred to in subparagraph 1 shall be sentenced in a similar manner. What is provided above in this subparagraph does not apply if violence has been used in the rape.

(CC 20:1.3/2014/509)

The definition of rape includes intercourse. Other sexual acts using force or the abuse of helplessness and similar states constitute the crime of coercion to engage in a sexual act (CC 20:4). The sexual abuse of people in dependent situations is also a crime (CC 20:5). Sex with someone who is 15 years old or younger is considered child sexual abuse (CC 20:6), which we do not discuss in this chapter.

When Finnish rape law was reviewed in 2013, the government discussed the possibility of changing the basic element of rape to sexual non-consent (Ministry of Justice, 2012; RP 216/2013). According to the Finnish government, those countries where a lack of consent is an essential element of rape also have additional evidential rules concerning valid consent. Such evidentiary rules define the circumstances under which adequate consent can be given. The government concluded that such evidentiary rules are not in line with the theoretical doctrines of evidence, based on the free evaluation of evidence. According to the government, the idea that sexual partners would take active steps to determine whether their partners had consented to sex was unnatural (or 'otherworldly', according to RP 216/2013, 37).

Notwithstanding the legal definition, the core problem in the Finnish courts is whether the complainant has consented to a sexual act (Ylikulju, 2017). The Supreme Court (KKO, from the Finnish Korkein Oikeus) has interpreted the elements of force, fear and helplessness:

Because A had said no to the [defendant] ..., the groping and pushing to the bedroom as well as the sitting on top of A, as described in the 
indictment, fulfil the element of violence. Due to the violence and fear and helplessness caused by it, A had been forced to [have] intercourse.

(KKO:2013:96, 46)

According to the Supreme Court, the complainant was proved to have tried to push the defendant away before the rape and that she had forbidden the defendant to continue. The defendant had admitted that he had heard the complainant's refusal. The Supreme Court considered the question of consent:

The Supreme Court states as a point of departure that one cannot derive a consent to [have] intercourse solely on the basis of ending physical or even verbal resistance after having first denied it. The intent or criminal liability is not avoided just because one assumes that the other has changed her mind if the change of mind has not been verbally or otherwise clearly expressed.

(KKO:2013:96, 48)

While the Supreme Court does not explicitly discuss trust in this case, the situation had evolved such that ' $\mathrm{A}$ ' - who knew ' $\mathrm{K}$ ' as an employer of a friend and wished to be hired at K's bar - had invited $\mathrm{K}$ to her apartment. These circumstances indicated some degree of trust in K. The case shows how the interpretation of the use-of-force construction has come close to the lack-of-consent construction, as required by international law instruments. The judgement does not include an explicit reference to the ECtHR decision in M. C. v Bulgaria (2003) nor to the Istanbul Convention, ${ }^{3}$ but the interpretation that use of force actually means lack of consent provides reason to assume that the Supreme Court is aware of the case and the Convention.

\section{International law: from coercive circumstances to consent}

Rape arrived on the agenda of international law under cruel circumstances. Both the ICTR and the ICTY had to consider the elements of rape. The ICTR in Akayesu (1998) and the ICTY in Kunarac (2002) held that the circumstances of the cases were coercive and that consent was therefore irrelevant. ${ }^{4}$ Rape was defined in international law for the first time in the Akayesu case (Munro, 2010); soon after, the statute of the International Criminal Court recognised rape as a war crime and as a crime against humanity (art. 4[c] and 7[1]g; Cole, 2010; Walby et al., 2015, pp. 115-118).

The coercive-circumstances formulation highlights, among other things, the power relationship between parties (MacKinnon, 2006, p. 941). In these cases, the power imbalance was extreme, but the cases raise the question of what kind of coercive circumstances would generally make consent irrelevant. MacKinnon (2006, p. 951) criticised the tribunals for binding the coercive circumstances too closely with the lack-of-consent definition of rape. The use-of-force construction of rape in the Akayesu and Kunarac cases would not solve the issue, because in these cases, the rapes had not been preceded by immediate force or threat. 
Rape remained on the international-law agenda after the Akayesu case, but with an emphasis on lack of consent (UNDAW, 2010, p. 26). The ECtHR stated in M. C. $v$ Bulgaria (2003) that rape should be defined as a crime committed against one's consent. After a review of the definitions of rape in the Council of Europe member states, the ECtHR stated that most continental European definitions of rape are based on violence or threat of violence, whereas in common law, rape is usually constructed as lack of consent (M. C. $v$ Bulgaria, pp. 156-162). The ECtHR ruled that the central question of rape is whether the complainant has consented to engage in sexual activity, and that laws should be interpreted accordingly.

The suitability of the lack-of-consent approach in M. C. v Bulgaria can be questioned. The complainant in the case, a 14-year-old girl, was just above the age of consent, which in Bulgaria was 14 years at the time. She was in the company of three 20- to 21-year-old men in a lonely place when the alleged rape took place. No evidence was found of explicit violence, nor of resistance. The police and the prosecutor closed the case. The ECtHR referred to the coercive circumstances but did not deliberate on them:

The prosecutors forwent the possibility of proving the perpetrators' mens rea by assessing all the surrounding circumstances, such as evidence that they had deliberately misled the applicant in order to take her to a deserted area, thus creating an environment of coercion, and also by judging the credibility of the versions of the facts proposed by the three men and witnesses called by them.

(ECtHR M. C. v Bulgaria, p. 180; emphasis added)

The ECtHR has also examined other cases of the rape of young women in which the court could have considered the legal relevance of the circumstances more broadly (X\& Yv the Netherlands, 1985; Aydin v Turkey, 1997; Maslova \& Nalbandov v Russia, 2008, p. 91; I. G. v Moldova, 2012). In M. C. v Bulgaria, the legal analysis and conclusions were focussed on the interpretation of the use-of-force element in Bulgarian law to include lack of consent. Thus, the crucial moment to develop an interpretation of coercive circumstances was lost. Subsequent analyses of the case have not paid sufficient attention to the coercive circumstances the court mentioned but emphasise consent as the element of rape.

With the judgement of $M$. C. v Bulgaria, the lack of sexual consent became the core element of European rape laws. The European Convention on preventing and combating violence against women and domestic violence (Istanbul Convention 2011) confirms this notion in article 36 , which says that the parties to the Convention must take necessary legislative or other measures to ensure that engaging in non-consensual penetrative or other acts of sexual nature will be criminalised. In addition, the Committee on the Elimination of Discrimination against Women (the CEDAW Committee), in its concluding observations on various country reports, urged the states to set lack of consent as the core element of rape. ${ }^{5}$ As we discuss in the following section, both the lack-of-consent and use-of-force constructions define the context of rape narrowly - in our opinion too narrowly. 


\section{Consent versus force - a false controversy?}

\section{Act-oriented criminal law}

The protected good or interest of rape law is usually defined as sexual selfdetermination. In law drafting and case law, the basic tenets of self-determination are seldom explicated. Self-determination (or 'individual autonomy') is the liberal conception of free sexual choice based on rational decision-making and the underlying mind-body distinction (Lacey, 1998). Both lack of consent and use of force are connected to the concept of autonomy, as feminist researchers have pointed out (Lacey, 1998). In the lack-of-consent construction, the focus is on the expression of opinion by a victim, thus emphasising a complainant's response to actions (earlier conceptualised as seduction) of a perpetrator (MacKinnon, 2016). In the use-of-force construction, the focus is on the denial of the will of the victim. Both constructions focus on the complainant's expression of determination (or the impossibility of expressing one) and exclude the context.

In criminal law, the ontology of a crime is act-oriented. The concrete acts must correspond to the elements as defined in criminal law according to the nullum crimen sine lege or legality principle, that all crimes must be prescribed in law. The level of concretisation of the elements varies. While definitions of crimes against property and the person are narrow in both time and space, in the definitions of economic and environmental crimes, the actions, causality and violations are defined abstractly, and the time span may be long. In the definition of a criminal act, the relevant context is constructed and to some degree contingent (Kelman, 1981; Lacey, Wells \& Quick, 2003; Smart, 1991). In addition to the concrete and objective elements of crime, the criminal responsibility requires a subjective element, usually intent (mens rea), which often is induced from the concrete actions (evidence of facts).

The evidential considerations seem to be similar, notwithstanding the definition of rape. In legal practice, rape is usually established evidentially by virtue of physical signs (physical marks and injuries) as a result of violence and resistance (Jokila, 2010). A complainant's state of mind and behaviour after an alleged rape has occurred are typically used as supporting evidence for the prosecutor's case.

Andersson (2004) concluded in her empirical study that the victims were not thought of as legal actors, except in response to the advances by the perpetrator. According to Jokila's study (2010), the defendants often argued that the complainant had consented. The reporting of facts by the defendants and their lawyers during pre-trial investigations and in written pleadings in that study demonstrated discriminating attitudes towards women and prejudice about male and female sexuality. Pejorative attitudes by the defence have been a widespread problem in criminal justice, regardless of whether the use-of-violence or lack-of-consent models are used (Adler, 1987; Estrich, 1987; Lees, 1996). In two Finnish studies, such prejudicial language was not observed in the verdicts (Jokila, 2010; Ylikulju, 


\section{Helena Jokila and Johanna Niemi}

2017), but the language of the defendants and their lawyers reflected prejudice about the victim, such as interpreting paralysing fear as voluntariness, sexual foreplay and tacit consent (Jokila, 2010). ${ }^{6}$

\section{Rape in intimate relationships}

Historically, rape in marriage was not a crime before the mid-20th century (Burgess-Jackson, 1996; Kotanen's chapter in this volume). Rape in marriage was criminalised in Sweden in 1965, in Canada in 1983, in the UK in the early 1990s (ECtHR, R. C. v UK, 1995) and in Finland in 1994. Already in 1990, Russell found that rape in marriage was more common than previously assumed (Russell, 1990). Intimate partnerships take many forms today, as cohabitation is commonplace. In court cases it is not always clear what the status of a relationship is; on-and-off relationships are not uncommon.

In the Finnish appeal courts in 1999-2002, 18\% of rapes were found to have taken place in intimate partnerships (Jokila, 2010, p. 160). Typically, violence in these cases had been physical, psychological and sexual, repeated and continued over long periods of time. The acts included in the indictment were only a snapshot of long-lasting violence that in some cases continued after the investigation and prosecution had commenced. In these cases, the defendants were usually convicted (Jokila, 2010, p. 171), but in some cases, the type of relationship alleviated the sentence. In some cases, the court dismissed the charges with some of several rapes, and in others the conviction was of rape of a lesser grade (CC 20:1.3).

The courts were willing to stretch the context in these cases, but they obviously had to struggle with the elements of rape. When the victim had not resisted, the courts were sometimes willing to take previous violence into account:

The victim had not dared to resist the defendant because she feared that resistance would lead to violence as had happened before. According to the victim the defendant had not threatened her verbally.

(District Court, 11)

The court discussed how the capacity to self-determination was broken and how this lack could affect the ability of the victim to provide a coherent testimony:

Imprecision (in testimony) can be explained by the nature of crimes against sexual self-determination. An indecent crime takes place by breaking the will of the victim and it always has an effect on the state of mind of the victim.

(District Court, 11)

The defendant was convicted of lesser grade rape (CC 20:1.3). In another case, in which violence preceding the actual rape had also occurred, the defendant was convicted of rape. According to the complainant's appeal in that case: 
The defendant has threatened and assaulted her physically for many years. The complainant has been traumatized, and she is so afraid of her husband, that she doesn't dare to resist his wishes and orders. The complainant has told in the court, that if she somehow resists the defendant, the defendant usually begins to threaten her life. (The complainant's appeal to the Court of Appeal, Court of Appeal 64.)

In this and similar cases, the courts encountered problems in understanding why the victim had let the estranged spouse into the apartment in the first place. The victims had tried to use different strategies to avoid violence and disturbance:

When the defendant shows up at her home, the complainant doesn't always dare to ask the defendant to leave, because she is afraid that he would become violent.

(Court of Appeal, 64)

A discourse of involuntary consent appears in these cases:

Even though the victim testimony as such is credible, the evaluation of evidence about the number of rapes is difficult because the parties have also had several times intercourse that the victim has not wanted but that she nevertheless has consented to.

(Court of Appeal, 2)

In these cases, the core problem was whether or not a complainant had consented to a sexual act - even if consent is not a definitional element of rape in Finland. Thus, it is unlikely that problems at the level of legal application and evaluation of evidence would be solved solely by adapting consent as part of the definition of rape. Problems often originate from difficulties in distinguishing freely given consent from submission, paralysing fear or a complainant's strategic inaction (Ehrlich, 2001).

In some judgements, the courts have focussed on fear and coercion. In one case, the perpetrator did not use immediate violence to break the complainant's resistance but held the complainant against her will in an apartment for six hours. He threatened her, assaulted her, tried to strangle her and finally raped her. She was so afraid that she was unable to defend herself. The defendant argued that there was a time gap between the violence and the sexual intercourse and that the parties had solved their previous conflict before having sex. When sentencing, the courts evaluated the totality of the defendant's separate crimes in sentencing the punishment (Kouvola Court of Appeal 22.11.2011, no. 1082).

A complainant who, paralysed by fear, submits to intercourse can be held as consenting, albeit against her will. In one judgement, the core problem was how to adjudicate sexual acts that 'the complainant had not wanted, but that she nevertheless had consented [to]'. In such situations, fear and passivity were often a consequence of the perpetrator's previous violence: 
When the defendant shows up to her home, the complainant doesn't always dare to ask the defendant to leave, because she is afraid that he would become violent. The complainant has also told in court that sexual [intercourse has] happened in situations, which, according to the complainant's previous experience, would have resulted in rape, if the complainant wouldn't [voluntarily] agree to sexual intercourse.

(Court of Appeal, 64)

Intimate partner rape, the complainant's incapacity to form or utter her will, and the problem of 'involuntary consent' are all connected to coercive circumstances in violent relationships that have broken the autonomy and trust of the victim. In Appeal Court cases, the autonomy of the victims looks especially weak and fragile if the perpetrator is a family member or otherwise close. In these cases, trust has been destroyed a long time before the rape trial commences. The typical descriptions of facts in legal documents indicate that such victims have great difficulties in setting boundaries, taking care of themselves, and trusting their own experiences and interpretations of events. Many of these victims seem mentally fragile or mentally broken, and they seem to lack selfconfidence and self-respect.

\section{Rape and youth}

Rape cases involving young parties may cause even more trouble to the courts than rapes in intimate partnerships due to problems of autonomy and the circumstances of rape. In cases of child sexual abuse, trust in the relationship between the perpetrator and the victim is a standard factor that the Supreme Court refers to, which indicates that the abuse of trust is an aggravating circumstance (KKO:2018:35; 2018:30; 2017:51; 2017:50; 2017:31; 2011:102). In this part, we analyse cases in which the victim has been above the legal age of consent but nevertheless young: 16-19 years old.

The Supreme Court has provided only a few verdicts in rape cases, and trust was not considered to be a central element in those cases. In district and appeal courts, discourse on trust has circulated in some trials, thus shaping the ways in which knowledge of the events was constructed. Jokila (2010) found that a trust discourse was present in explanations of why a complainant had spent time with the defendant before the alleged crime took place or why she had let him into or gone with him to an apartment. The question of whether a complainant had voluntarily entered or had been forced into an apartment played a central role in the evaluation of evidence in one Supreme Court case (KKO:2004:60).

The courts do not always take an explicit 'no' by a young woman for a 'no'. In one case, the defendant had already come on to her by the time they were going to the apartment of the defendant's sister. They were lying on a bed when the defendant continued his sexual approaches. The defendant's sister testified that the complainant had told the defendant to stop several times; she did not 
intervene, however, because it did not sound like the complainant needed help. After the sexual act, the complainant smoked a cigarette together with the defendant and the sister. They talked about contraception, not about violence. The complainant returned to the apartment, where the defendant came on to her once more. The complainant now pushed him away and hit him in the face. The Court of Appeal (106) dismissed the charge of lower degree rape. The court stated that the complainant's behaviour after the sexual act supported the defendant's version of events.

This case could be interpreted differently. Understood in the context of anxiety and confusion, the girl's behaviour is understandable. She was young. She tried to tell him to stop. Her behaviour afterwards could tell of agony, confusion and breach of trust by the defendant. Afterwards, she hung out for a while with the defendant and the witness, likely to preserve her honour in the eyes of her friends and to try to avoid the stigma of being a rape victim. She may have been ashamed of not having asserted herself against the defendant and not controlling the situation.

Another case, this one between dating teenagers, showed evidence of the complainant having complained and cried after intercourse. According to the reasoning in the verdict of the District Court, the complainant had described how she had tried to persuade the defendant to stop, but she did it in such a way that other people in the house would not be awakened. She had told him that she did not approve of premarital sex and tried to get up from the bed. She had tried to negotiate. She had trusted him and had been confident that he would listen to her and respect her will. Afterwards, she was confused and in shock. The Court of Appeal was not convinced that she had resisted earlier, so the charge of lower grade rape was dismissed (Court of Appeal, 90).

Jokila's study (2010) showed that it is often difficult for courts to understand young women. She found that if the complainant went with the defendant voluntarily to an apartment, tried to tell him to stop (instead of resisting physically and fighting back) and finally stayed in the apartment afterwards, then charges were sometimes dismissed due to lack of evidence (e.g. Court of Appeal, 90 and 106).

Such complainants do not fit in with the idea of the autonomous rational decision-maker who assertively expresses her non-consent and fights against her attacker. But if trust is taken into account in the interpretation of events, then some of these behaviours can be understood. For example, girls are traditionally brought up to behave nicely and to negotiate themselves out of difficult situations. When in the company of someone whom the girl trusts, these tactics should succeed. When confused by the breach of trust, however, the girl might behave, from a judge's perspective, in a strange manner.

In one case (Court of Appeal, 5), rape was committed against a teenage boy. Both the District Court and the Court of Appeal considered the breach of trust to be a relevant element. The boy had met the defendant in a mall. They knew each other, since they were from the same country. Therefore, the boy trusted the defendant and accepted his invitation to his apartment, where the 
defendant gave him alcohol. He then got drunk, lost consciousness and was anally raped.

In Jokila's study (2010), breach of trust was sometimes a relevant factor. One court called rape 'the price for the misplaced trust' (District Court verdict, 53). The lawyers sometimes used the trust discourse to explain why a complainant had spent time with the defendant before the crime. The complainant might explain that she had gone to his place because she trusted him (complainant's statement, 66). In one case, the complainant's lawyer argued with the trust notion and depicted the defendant as someone who had created a feeling of trust between the victim and himself, only to abuse it (written statement, District Court, 56). Further, the court argued for the betrayal of trust over the relevance of mental damage in a case where a disabled girl had trusted the perpetrator (District Court, 88).

\section{Conclusion}

International courts and the Istanbul Convention emphasise that sexual acts should take place with the consent of both parties. This preference for lack of consent over use of force as the central element of rape in criminal law reflects the value of sexual self-determination and autonomy and the protection of the privacy and integrity of the person. In national jurisdictions, the interpretation of use of force in legal definitions has approached the lack-of-consent formulation.

The international tribunals discussed in this chapter have also underlined that cases of sexual intercourse under coercive circumstances should be convicted as rape, even if no immediate violence and force have been used, no direct threats have been given, nor explicit consent has been expressed. Some have argued that coercive circumstances are relevant for situations of war and violent conflict, and that such circumstances would not need to be considered as much during normal states of affairs. Our empirical data suggest otherwise.

In this chapter, we have looked at rape in intimate partnerships and rape among youth. Both the lack-of-consent and the use-of-force constructions focus on the events immediately before and during the rape, whereas in our cases the broader context of coercion was what led to involuntary intercourse. In the cases of intimate partner rape, the victim's autonomy seems to have been restrained to start with; a long history of violence and control formed coercive circumstances in these cases. These victims could not set boundaries, nor did they trust the adequacy of their own experience and interpretation of what had happened between the couple.

The behaviour of the young victims (between the ages of 16 and 19) seemed to be very difficult for the courts to understand. They appeared to have acted illogically. The courts paid attention to how the victim had ended up in the apartment, whether voluntarily or by force - not that the courts reasoned that the specifics of the situation would be part of the elements of 
rape, but that they could be concrete evidentiary facts to rely on. The victims often had not explicitly resisted, and the courts did not value their attempts to negotiate their way out of the situation as evidence. In these cases, the courts reasoned using the trust argument, as they also typically do in cases of child sexual abuse. Thus, trust can be used as a strategy to counter prejudicial assumptions about a complainant's personality and behaviour before, during and after rape.

Trust is essential for autonomy. Trust in human relationships promotes and enables the development of personal autonomy. Trust can also be situational. Our analysis of case law suggests that trust should be analysed in rape cases, in terms of how it is built and how it is broken. Using trust as a central concept, the courts could be more understanding towards young people and could avoid making prejudicial assumptions about a victim's personality and behaviour.

\section{Acknowledgements}

We thank the reviewer and the editors for their valuable comments. This chapter was written as part of research funded by the Academy of Finland, decisions 281788 and 284929.

\section{Notes}

1 Criminal Code, chapter 20, L 563/1998. Available in English at www.finlex.fi/en/laki/ kaannokset/1889/en18890039.pdf.

2 The 1999 law, reforming Chapter 20 of the CC, included a difference between abusing a victim's state of mind (the crime of sexual abuse) and inducing a person into such a state of mind and then committing abuse, which fell under the rape category. In 2011, both actions were placed under the rape category.

3 The 2011 Council of Europe Convention on preventing and combating violence against women and domestic violence, European Treaty Series (ETS) 201. Finland ratified the Convention in 2015.

4 The 1994 Rwandan genocide of the Tutsi minority at the hands of the Hutus included, in addition to the widespread systematic killing of Tutsis, the rampant rape of Tutsi women. Kunarac refers to a case about a group of Muslim women held in sexual enslavement in the city of Foça, Bosnia and Herzegovina, by Serb forces during the Bosnian war of 1992-1995.

5 Such as CEDAW Committee, 7th periodic report of Finland (2014).

6 Susan Ehrlich (2001) found similar interpretations of fear as consent in her Canadian, discourse-analytical study on rape. Ehrlich studied the ways in which legal facts were constructed in two rape cases against young female students, in a university campus.

\section{References}

Adler, Z. (1987). Rape on trial. London: Routledge \& Kegan.

Andersson, U. (2004). Hans (ord) eller hennes: En könsteoretisk analys av straffrättsligt skydd mot sexuella övergrep. [His (word) or Hers? A gender theoretical analysis of criminal legal protection against sexual abuse]. Lund, Sweden: Bokbox.

Asp, P. (2010). Sex och samtycke [Sex and consent]. Uppsala, Sweden: Iustus Förlag. 


\section{Helena Jokila and Johanna Niemi}

Bennet, W., \& Feldman, M. (1984). Reconstructing reality in the courtroom: Justice and judgement in American culture. New Brunswick, NJ: Rutgers University Press.

Berger, P. L., \& Luckmann, T. (1966). The social construction of reality: A treatise in the sociology of knowledge. Harmondsworth, UK: Penguin.

Boyle, C. (1984). Sexual assault. Toronto: Carswell.

Brothers, D. (1982). Trust disturbances among rape and incest victims. $\mathrm{PhD}$ dissertation. New York: Graduate School, Yeshiva University.

Brownmiller, S. (1974; reprinted 1993). Against our will: Men, women, and rape. New York: Fawcett Columbine.

Burgess-Jackson, K. (1996). Rape: A philosophical investigation. Aldershot, UK: Dartmouth.

Burr, V. (1995). An introduction to social constructionism. London: Routledge.

Cole, A. (2010). International criminal law and sexual violence: An overview. In V. Munro \& C. McGlynn (Eds.), Rethinking rape law: International and comparative perspectives (pp. 47-60). London: Routledge.

Davies, M. (2001). Are persons property? Legal debates about property and personality. Aldershot, UK: Ashgate/Dartmouth.

Ehrlich, S. (2001). Representing rape: Language and sexual consent. London: Routledge.

Estrich, S. (1987). Real rape. Cambridge, MA: Harvard University Press.

Fineman, M. A. (2004). The autonomy myth: A theory of dependency. New York: New Press.

Gidycz, C. A., \& Koss, M. P. (1991). The effects of acquaintance rape on the female victim. In A. Parrot \& L. Bechhofer (Eds.), Acquaintance rape: The hidden crime (pp. 270-283). New York: John Wiley \& Sons.

Gotell, L. (2010). Canadian sexual assault law: Neoliberalism and the erosion of feministinspired law reforms. In C. McGlynn \& V. E. Munro (Eds.), Rethinking rape law: International and comparative perspectives (pp. 209-223). New York: Routledge.

Govier, T. (1993). Self-trust, autonomy, and self-esteem. Hypatia, 8(1), 99-120.

Halley, J. (2016). The move to affirmative consent. Signs: Journal of Women in Culture and Society, 42(8), 257-279.

Iceland Review (2018). Parliament votes to change definition of rape. March 25th 2018.

Jokila, H. (2010). Tahdonvastainen suostumus ja liiallisen luottamuksen hinta: Raiskauksen ja muiden seksuaalirikosten oikeudellisen tiedon konstruktiot [Consent against one's will and the price of undue trust]. Helsinki: Suomalainen Lakimiesyhdistys.

Katz, B. (1991). The psychological impact of stranger versus nonstranger rape on victims' recovery. In A. Parrot \& L. Bechhofer (Eds.), Acquaintance rape: The hidden crime (pp. 251-269). New York: John Wiley \& Sons.

Kelman, M. (1981). Interpretive construction in the substantive criminal law. Stanford Law Review, 33(4), 591-673. doi: 10.2307/1228535

Lacey, N. (1998). Unspeakable subjects, impossible rights: Sexuality, integrity and criminal law. Canadian Journal of Law and Jurisprudence, XI(1), 47-68.

Lacey, N., Wells, C., \& Quick, O. (2003). Reconstructing criminal law: Texts and materials (3rd ed.). Cambridge, UK: Cambridge University Press.

Lees, S. (1996). Carnal knowledge: Rape on trial. London: Hamish Hamilton.

Leijonhufvud, M. (2008). Samtyckesutredningen: Lagskydd för den sexuella integriteten. Stockholm: Thomson. 
MacKinnon, C. A. (1996). Rape: On coercion and consent. In D. K. Weisberg (Ed.), Applications of feminist legal theory to women's lives: Sex, violence, work and reproduction (pp. 471-483). Philadelphia: Temple University Press.

MacKinnon, C. A. (2006). Defining rape internationally: A comment on Akayesu. Columbia Journal of Transnational Law, 44(3), 940-958.

MacKinnon, C. A. (2016). Rape redefined. Harvard Law \& Policy Review, 10(2), 431-477.

McGlynn, C., \& Munro, V. E. (Eds.) (2010). Rethinking rape law: International and comparative perspectives. New York: Routledge.

Ministry of Justice (2012) Justitieministeriets publikation. Behoven av att ändra lagstiftningen om våldtäktsbrott (bedömningspromemoria; utredningar och anvisningar 25/ 2012) [The need of rape law reform]. Finland.

Munro, V. (2010). From consent to coercion: Evaluating international and domestic frameworks for the criminalization of rape. In C. McGlynn \& V. E. Munro (Eds.), Rethinking rape law: International and comparative perspectives (pp. 17-29). New York: Routledge.

Naffine, N. (2011). Women and the cast of legal persons. In J. Jones, A. Grear, R. A. Fenton, \& K. Stevenson (Eds.), Gender, sexualities and law (pp. 15-25). Oxford, UK: Routledge.

Näre, S. (2000). Nuorten tyttöjen kohtaama seksuaalinen väkivalta ja loukattu luottamus tunnetaloudessa. In P. Honkatukia, J. Niemi-Kiesiläinen, \& S. Näre (Eds.), Lähentelystä raiskauksiin: Tyttöjen kokemuksia häirinnästä ja seksuaalisesta väkivallasta [The experiences of girls on sexual harassment and violence] (pp. 77-135). Helsinki: Nuorisotutkimusseura.

Nedelsky, J. (1989). Reconceiving autonomy: Sources, thoughts and possibilities. Yale Journal of Law and Feminism, 1(1), 7-36.

Niemi-Kiesiläinen, J., Honkatukia, P., \& Ruuskanen, M. (2007). Legal texts as discourses. In E.-M. Svensson, Å. Gunnarsson, \& M. Davies (Eds.), Exploiting the limits of law (pp. 69-88). Dartmouth, UK: Ashgate.

O'Donovan, K. (1997). With sense, consent, or just a con? Legal subjects in the discourse of autonomy. In N. Naffine \& R. J. Owens (Eds.), Sexing the subject of law (pp. 47-64). London: Routledge.

Pineau, L. (1996). Date rape: A feminist analysis. In D. K. Weisberg (Ed.), Applications of feminist legal theory to women's lives: Sex violence, work, and reproduction (pp. 484494). Philadelphia: Temple University Press.

RP 216/2013 rd. (Finland). Regeringens proposition till riksdagen med förslag till lag om ändring av 20 kap. i strafflagen. [Government proposal for amendments in rape law].

Russell, D. E. H. (1990). Rape in marriage. Expanded and revised edition. Bloomington: Indiana University Press.

Smart, C. (1991). Feminism and the power of law. London: Routledge.

UNDAW. (2010). UN handbook for legislation on violence against women. New York: United Nations Publication.

Walby, S., Olive, P., Towers, J., Francis, B., Strid, S., Krizsan, A. \& Agarwal, B. (2015). Stopping rape: Towards a comprehensive policy. Bristol, UK: Polity Press.

Ylikulju, M. (2017). Raiskauksen toteennäyttäminen rikosprosessissa [Evidence in rape trials]. In J. Niemi, H. Kainulainen, \& P. Honkatukia (Eds.), Sukupuolistunut väkivalta: Oikeudellinen ja sosiaalinen ongelma [Gendered violence: A legal and social problem] (pp. 232-249). Tampere, Finland: Vastapaino. 


\section{Helena Jokila and Johanna Niemi}

\section{Laws and official documents}

Brottsbalk 1962:700 (Criminal Code) Sweden

CC Criminal Code 1889, Finland

CEDAW Committee (2014). Committee on the Elimination of Discrimination against Women. Report on the 7th periodic report of Finland.

Istanbul Convention (2011) The European Convention on preventing and combating violence against women and domestic violence. ETS 210.

\section{Cases}

European Court of Human Rights [ECtHR]

Aydin v Turkey, Sept 25th, 1997 Appl 28293/95, 29494/95 and 30219/96

I. G. v Moldova, May 15th, 2012 Appl 535/07

M. C. v Bulgaria, Dec 4th, 2003 Appl 39272/98

Maslova \& Nalbandov v Russia, Jan 24th, 2008, Appl 839/02

R. C. v UK, Nov 22nd 1995, Appl 20190/92

$X \& Y v$ the Netherlands, March 26th, 1985 Appl 8978/80

International Tribunals

ICTR Akayesu (1998) International Tribunal for Ruanda

ICTY Kunarac (2002) International Tribunal for Former Yugoslavia... 


\title{
9 Empowered or protected? The 'problem' of complainants' rights in Danish and Norwegian preparatory works on criminal procedure
}

\author{
Hildur Fjóla Antonsdóttir
}

\section{Introduction}

The demand for and move towards improved rights and legal representation for complainants in criminal cases in the Nordic countries may be traced back to the efforts of the 1970s women's movement. Concerns over the mistreatment of complainants within the criminal justice system, particularly in cases of rape, led to the introduction of the complainant's lawyer (CL). In 1980, Denmark became the first country to introduce the CL model, whereby complainants in cases of rape were afforded the right to have a state-paid lawyer appointed to guard their interests. The right to a CL was later expanded to include other types of sexual violence cases, cases of physical violence and other serious crimes directed against the person (Brienen and Hoegen, 2000, pp. 218-219). The CL model was subsequently taken up by the other Nordic countries. ${ }^{1}$ However, as I will discuss in more detail in the next section of this chapter, complainants' legal status and rights are significantly stronger in Finland and Sweden than they are in Norway, Denmark or Iceland.

In the mid-2000s, both Norway and Denmark enacted legislative amendments to strengthen the position of the complainant in the two countries' laws on criminal procedure. While Norwegian complainants were afforded participatory rights and stronger legal representation in court, this was largely not the case in Denmark. In this chapter, I will conduct a comparative analysis of the Norwegian and Danish legal policies that underpin the legislative changes in the two respective countries, using Carol Bacchi's (Bacchi, 2009; Bacchi \& Goodwin, 2016) 'What's the problem represented to be?' (WPR) approach. I will explore how the 'problem' of complainants' participatory rights and stronger legal representation in the criminal procedure is constructed, shaped and represented in policy documents, and how complainants in cases of sexual violence are construed.

\section{Complainants' status and rights in Nordic criminal procedures}

The legal status and rights of complainants in criminal procedural law are considered to be stronger in civil law countries than they are in common law countries, although these rights can vary between different jurisdictions (Brienen \& 
Hoegen, 2000; Doak, 2005). While the term 'Nordic law' is widely used when emphasising the considerable similarities between the laws, legal systems and legal cultures of the Nordic countries (Husa, Nuotio, \& Pihlajamäki, 2008), complainants' legal status and rights in criminal cases have historically been significantly stronger in Finland and Sweden than in Denmark, Norway or Iceland (Robberstad, 2002).

Today it is possible to discern three different models on the status and rights of complainants in the Nordic countries: (1) the Finnish/Swedish model, where complainants have the right to obtain party status, with the accompanying rights; (2) the Danish/Icelandic model, where complainants have the legal status of witnesses, with certain special but limited rights; and (3) the Norwegian model, which falls between the other two, where complainants have the status of witnesses but with more extensive rights, including certain participatory rights (Ertzeid, 2007).

Since the publication of Anne Robberstad's PhD thesis in law titled Between Duel and Inquisition: The Basic Structure of Criminal Procedure in Light of the Role of the Complainant (1999), Norway has led recent Nordic discussions on the legal status and rights of complainants. Robberstad, a former CL herself, presents an historical analysis that reveals how the status and rights of complainants in Norwegian law have weakened over the centuries and she makes a forceful argument for strengthening their rights. In 2001, the Norwegian government commissioned Robberstad to conduct a comparative legal analysis of the status and rights of complainants in the Nordic countries with a view to propose legislative approaches to strengthening their positions in procedural law. In November 2002, Robberstad presented her report, titled 'Contradiction and Dignity' (2002), at a seminar organised by the Nordic Council of Ministers. At the seminar, which was attended by legal practitioners from the Nordic countries, Robberstad proposed that complainants should be afforded the right to become parties to criminal cases if they so wish (Nordic Council of Ministers, 2004). Her work has subsequently informed legislative deliberations in Norway and Denmark. These deliberations are the focus of analysis in this chapter.

\section{Method}

I analyse the legal policy documents using Bacchi's (2009) WPR approach, which is a Foucault-inspired poststructural method of analysing policies in an effort to make politics visible. This approach relies on the notion that by asking how 'problems' are represented in policies 'it becomes possible to probe underlying assumptions that render these representations intelligible and the implications that follow for how lives are imagined and lived' (Bacchi \& Goodwin, 2016, p. 6). Following Bacchi's (2009) guiding questions for analysis, I focus on how the problem of complainants' participatory rights is represented, and particularly how these problem representations are possible, by identifying which assumptions underpin them and which discourses shape them. In addition, I will analyse what remains unproblematised in the problem representations. Using a comparative approach is helpful for this purpose, 
as doing so enables the identification of the production of contrasting problematisations (Bacchi \& Goodwin, 2016, p. 23).

Finally, I will pay attention to the effects of particular problem representations. Bacchi and Goodwin (2016) have identified three different types of effects: discursive effects draw our attention to how particular problem representations limit what can be thought and said, while subjectification effects highlight how 'subjects' are implicated in problem representations and how they are specifically produced; finally, lived effects refer to how discursive and subjectification effects translate into people's lives.

I analyse the preparatory works that have accompanied the legislative amendments pertaining to the status and rights of complainants in Norway and Denmark, including early and later stages of preparatory works. The later stages of preparatory works are the actual explanatory texts accompanying the legislation. The early stages are reports based on deliberations and legislative recommendations by (1) the Standing Committee on Administration of Criminal Justice (SCACJ) of the Danish Ministry of Justice (Justitsministeriets Strafferetsplejeudvalg), and (2) an ad hoc commission (henceforth 'the Commission') appointed by the Norwegian Ministry of Justice and Public Security. The legislation enacted (or not) in both countries is closely based on the recommendations found in the reports published by the SCACJ and the Commission; these reports are thus the main focus of my analysis. In the case of Denmark, two separate reports were produced: the first addresses the legal position of complainants in rape cases, while the second addresses the position of complainants more generally (see Betænkning, 2005, 2006). In Norway, only one report was produced to address the position of complainants more generally (see NOU, 2006).

The reports are generally structured to include the following: an introduction, with the committees' mandates; a detailed overview of the current legislation; a review of what is considered relevant material, such as the outcome of consultations/hearings, previous reports and legislation in other Nordic countries; the committees' deliberations, considerations and suggestions; and finally legislative proposals. As will be discussed in more detail below, the Norwegian report is more expansive, as it also includes a discussion of the practical experiences of criminal justice procedures from the other Nordic countries, the outcomes of consultations with complainants and their next of kin, and a discussion of EU and UN policy and legislative developments.

Finally, the report excerpts presented in the following analysis have been translated from Danish and Norwegian to English.

\section{Backgrounds to Norwegian/Danish legal policy procedures}

The Norwegian and Danish policy processes have both similarities and differences. As discussed in the introduction to this chapter, the legislative developments to date to strengthen complainants' rights in Norway are largely based on Robberstad's work (1999; 2002). Robberstad (1999) has shown how the main 
obstacle for strengthening complainants' procedural rights, particularly their participatory rights, in the west Nordic context has been the interpretation of the equality of arms principle, which is related to the notion of fairness enshrined in Article 6(1) of the European Convention on Human Rights on the right to a fair trial. Equality of arms is often broadly defined as 'the requirement that a balance of fairness is maintained between parties' (Summers, 2007, p. 105). Robberstad (1999) has shown how, in the Norwegian context, the equality of arms principle has been interpreted to mean a requirement of equality between parties, without explaining what is actually meant by equality in this context. This interpretation has led to the common assumption that the two parties, the state and the accused, have to be equally strong - a scenario that has been partly exasperated by the conceptualisation of the trial as a form of battle or a sporting game in Norwegian legal discourse (similarly to the Anglo-American legal discourse) and that the two teams must have the same number of players. She critically notes that this conceptualisation is also encouraged by the metaphorical term 'equality of arms' in reference to military battle. Robberstad (1999) coined the term the 'balance illusion' to critique the notion that affording complainants party status in the criminal case, along with accompanying participatory rights, is equivalent to a 'two against one' scenario, thus jeopardising the equality of arms principle. Based on her review of the interpretation of this principle in the case law of the European Court of Human Rights, Robberstad concludes that the equality of arms principle does not preclude the strengthening of the rights of complainants, as long as the defendant's rights, for example to be heard and to raise objections, are upheld.

Niemi-Kiesiläinen (2001) has argued that although Robberstad's (1999) work was not presented in a feminist theoretical framework, it is underpinned by a feminist understanding of the subject matter. Niemi-Kiesiläinen points out that the metaphor of the trial as a duel or a game has obvious gendered connotations when analysed against the backdrop of the traditional roles and attributes assigned to men. She further notes that the use of such gendered metaphors makes the system more outlandish to ordinary people, and particularly women, even though the legal arrangement of the criminal justice system itself might not be gendered. And, since women are more likely to enter the criminal justice system as complainants than as accused, they are the ones who become excluded from the 'game'. Finally, the legal status of a witness implies a more passive role, which can easily be associated with traditionally ascribed 'feminine' attributes (NiemiKiesiläinen, 2001).

In that sense, the strengthening of the legal position of complainants in the Norwegian and Danish contexts is informed by feminist knowledge practices. Indeed, the legislative amendments in Norway were enacted on 7 March 2008 and were presented as a gift to women from the Norwegian government on 8 March, International Women's Day (Robberstad, 2014). In the case of Denmark, the impetus for initiating the policy process may be traced back to September 2003, when the Danish Association for Women's Rights (Dansk Forening for Kvinderet) held a conference on rape where the question of how 
to strengthen the legal status of complainants in rape cases was debated. Following that conference, the parliament asked the Ministry of Justice to suggest measures to improve the position of complainants in rape cases (Betænkning, 2005). The Danish policy process was informed by Robberstad's work via the Nordic Council of Ministers.

Now let us turn to the composition of the committees charged with reviewing complainants' legal positions. While the Danish Minister of Justice charged the ministry's SCACJ with conducting the review (Betænkning, 2005; 2006), the Norwegian Ministry of Justice and Public Security appointed the ad hoc Commission noted earlier to do the same (NOU, 2006). The composition of these committees was fairly similar, however, as they both comprised seven legal practitioners from the criminal justice system, including judges, prosecutors, practising lawyers and police representatives. In terms of the differences, the Danish SCACJ additionally included a legal scholar and a ministry representative, while the Norwegian Commission included one representative from an NGO who is well known in Norway for advocating for increased procedural rights for complainants and their next of kin. Nordic ad hoc commissions have traditionally been characterised by broad interest representation, although a recent analysis has shown that academics increasingly make up a substantial proportion of commission members (Christensen \& Holst, 2017). In this case, however, there was not much difference between the member composition of the Danish SCACJ and the Norwegian Commission, which indicates that criminal procedural law in these countries is largely understood to be the domain of expert legal practitioners in the criminal justice system, with only minimal, if any, representation from extra-legal stakeholders.

The mandate of the committees was similar, in that both were charged with reviewing the legal position of complainants in procedural law, with a view to improving their position; however, there were also some differences. The Norwegian Commission's mandate was to suggest 'how' the procedural position of complainants could be strengthened (NOU, 2006, p. 13), and if increased rights should apply generally to all complainants or only complainants in certain cases, such as cases of sexual violence and other cases of violence. The Danish SCACJ was charged with assessing 'if' there was a 'need' for legislative improvements (Betænkning, 2005, p. 11). The SCACJ's mandate was based on a parliamentary decision, the primary concern of which was to strengthen the position of complainants in cases of rape. The Minister of Justice also asked the SCACJ to assess the need for improvements in the context of criminal cases more generally. In comparing the mandates, one could argue that a clearer political will existed in Norway to enact meaningful legislative changes in order to strengthen complainants' legal position than was the case in Denmark.

That said, both policy processes were informed by external consultations. Previous to the appointment of the Norwegian Commission, a hearing had been conducted on Robberstad's (2002) report in which she had suggested affording complainants party status in criminal cases. A total of 64 responses were received. Of those who took a clear position on the issue of affording complainants full party 
status, 23 were against and 21 supported the suggestion. The responses showed a clear dividing line between victims' organisations and other interest groups, who supported the proposal, versus members of the criminal justice system, in particular the courts and the prosecution authorities, who did not (NOU, 2006).

Prior to the work of the Danish SCACJ, the Ministry of Justice sent a detailed questionnaire to 42 institutions and organisations. The questionnaire included questions both on how the then-current procedural laws worked in practice for complainants in rape cases and on whether a need existed to improve their rights, including the active rights of their CLs. The ministry received a total of 38 responses, the majority of which were from courts and police precincts and three lawyers' associations; the ministry also received responses from a rape crisis centre and two NGOs that provide support to victim-survivors of rape and other crimes (Betænkning, 2005). In short, the responses from the criminal justice system generally did not recommend strengthening complainants' participatory rights, and only one NGO suggested that complainants should be able to join the criminal case and thereby obtain party status (Betænkning, 2006). Based on the results from both the Danish and Norwegian consultation processes, it is clear that the main resistance to affording complainants and their CLs increased rights to participate in the court procedure primarily comes from the majority legal community within the criminal justice system. These results also indicate that the community of victims' organisations and other interests groups in Norway is larger and more robust than it is in Denmark.

Finally, several additional differences between the policy procedures should be mentioned. The Norwegian Commission was also mandated with assessing the needs of complainants for party rights. The Commission therefore conducted 15 meetings with complainants (and their next of kin) about their experiences with the criminal justice system. The mandate also requested that the Commission conduct country visits to Finland and Sweden to assess how complainants' party rights functioned in practice in those countries. The Norwegian Commission also drew on international and domestic legal and extralegal sources in its report, including EU and UN laws and policies, as well as socio-legal and victimological research (NOU, 2006). The Danish SCACJ, in contrast, did not conduct any consultations with complainants and did not conduct country visits to Finland or Sweden; instead, the group largely relied on domestic legal sources.

\section{Legislative results of the Norwegian and Danish policy processes}

Given the varied and detailed legislative amendments resulting from these policy processes, it is impossible to provide a full account of them in this chapter. Instead, I will endeavour to summarise some of the main changes, with an emphasis on complainants' participatory rights and the rights of their lawyers in court. 
In the case of Norway, the legislative changes included the following: (1) the clarification and spelling out of certain rights that were previously only implied by the complainants' legal standing in terms of civil claims, such as access to case documents during police investigations; (2) the right to comment on evidence presented in court (via their lawyers), as well as to provide final comments in court; and (3) the provision of additional rights unrelated to party status, such as the right to be informed about how the case is progressing in the criminal justice system. The order in which the complainant and the accused give their testimony in court was also changed. Before, defendants gave their testimony first, and so complainants were not permitted to sit in court and listen to their testimony, as doing so could affect their own testimony. Now, complainants give their testimony first, and they can therefore sit in court for the duration of the whole trial (Robberstad, 2014).

Some rights were only afforded to complainants to be exercised by their lawyers, such as the right to submit supplementary evidence and to ask supplementary questions of defendants, witnesses and experts in court once the prosecutor and the defence lawyer have concluded their questioning (Robberstad, 2014). But complainants were not afforded full party rights, such as the right to appeal. In this case, the majority of the Commission members found that complainants should not be given rights that would allow them to influence the question of guilt and the question of penalties, as they felt that such rights should solely be in the hands of the state (NOU, 2016).

In an effort to evaluate the effects of these legislative changes, Dullum (2016) recently interviewed 18 people who work within, or in relation to, the criminal justice system in Norway and asked them about their views on the matter. According to the research participants, complainants are now better represented and better prepared for criminal cases than before. In addition, they felt that the new participatory rights also seemed to aid in the restoration of self-respect and healing among complainants and that criminal cases themselves had acquired a more humane character. Participants' opinions differed on the question of whether complainants' rights had come into conflict with the rights of the accused, depending on their position within the criminal justice system. The majority of the participants, however, felt that complainants' increased rights had contributed to solving cases and had not been detrimental to the legal certainty of the accused. Exceptions included when the CL had taken on the role of an additional prosecutor and in cases with several complainants (and therefore several CLs) and one accused.

While the SCACJ did take note of the more progressive legislative developments in Norway, as well as the extensive rights complainants have in Finland and Sweden, the committee's suggestions were considerably more limited. When considering the rights of complainants in rape cases and other cases of sexual violence, the SCACJ's main point of departure was to ensure that complainants were 'better protected' (Betænkning, 2005, p. 13). The legislative amendments did include additional informational rights to ensure that complainants would receive guidance on their rights, especially in terms of their rights to 
legal representation, when reporting a case to the police. The amendments also included increased access for the CL to view case documents pertaining to their clients during the investigation stage, which now not only included their clients' police testimonies but also their medical records (Amendment to the Danish Administration of Justice Act, no. 558, 24 June 2005). This access is still more limited than in Norway, where CLs have more general access to case documents. The SCACJ considered whether the CL should have the right to object to questions about a complainant's previous sexual history but decided against this idea to ensure that the CL would not be involved in any questions regarding the evidence in the case. In the bill, however, which was passed in 2005, CLs were given the right to object to such questions, based on recommendations from the Ministry of Justice.

The question of whether complainants should have the right to give testimony in court before the accused - and thereby be able to observe the court proceedings - has been discussed extensively in Denmark (see Betænkning, 2006, 2010, 2014). Although the SCACJ has now provided draft legislation where complainants are afforded the right to give their testimony before the accused, the group did not endorse it (Betænkning, 2014); no such amendments have been enacted to date. In 2010, the Danish Standing Committee on Procedural Law (Retsplejeradet) also finalised a report that included legislative amendments to strengthen the legal position of complainants on the basis of their civil claims (Betænkning, 2010), but those proposals have also not been enacted to date.

The legislative changes proposed by the SCACJ are considerably more limited than those proposed by the Norwegian Commission and are primarily composed of small adjustments, with the aim of providing more protection for complainants. Unlike the case in Norway, the SCACJ thus did not propose the affording of complainants (via their lawyers) the right to submit and comment on evidence; nor the right to ask questions of the accused and witnesses in court. In the analysis below, I will explore the different problem representations and underlying assumptions that underpin these different legislative outcomes.

\section{Norway: Empowering rationally motivated female citizens and ensuring the rule of law}

In the Norwegian report, the 'problem' of complainants' participatory rights in court and stronger legal representation is typically represented in the form of such rights being lacking, in particular for certain groups of complainants. For the case of increasing complainants' rights, the underlying assumptions first include that such amendments would ensure the ongoing rule of law, which would otherwise be in jeopardy, and second that such rights would empower complainants and counteract their experiences of secondary victimisation.

The excerpts below highlight the first assumption underpinning the problem of complainants' lack of rights, i.e. that this lack jeopardises the rule of law. The discourses of citizenship, modernisation and social change are all evoked, thus shaping the problem representation. 
In a modern society, the individual's right to receive information about cases that concern them, to be able to object to information submitted by others and be able to express their views, is considered a basic condition for a good case procedure that provides a sense of security.

Social conditions, legal thinking, and people's expectations and education levels have changed significantly. ... Today, citizens have higher demands than before to receive information and have something to say in cases that affect them. Criminal cases are no exception.

If complainants' rights are not strengthened, the legal system can become out of step with people's understanding of the law. Over time, this will lead to a weakening of the trust that the legal system depends on.

(p. 16 and 124)

Nested within the problem representation is the notion that the criminal justice system is somehow exempt from the processes of modernisation and social change. Given that the results of the consultation process in Robberstad's (2002) report showed that resistance to affording complainants party rights overwhelmingly came from the majority community of legal practitioners within the criminal justice system, there is reason to assume that they are the ones who are primarily being addressed here. The discursive effects of this problem representation serve to warn the majority legal community that not strengthening complainants' rights will undermine citizens' trust in the legal system, which can be understood as a threat to the rule of law. These processes of modernisation and social change are also typically represented as entailing a set of changing factors, including social conditions and education levels. Although it is not entirely clear how these factors are qualified, the implication seems to be that they have improved.

In relation to these social changes, coupled with recent legal thinking and legislation, citizens are typically represented as having higher expectations vis-à-vis their relationship with the state. One of the subjectification effects produced by this problem representation is that complainants are represented as citizens first - as opposed to only victims of crime - and that the state has certain duties towards its citizens, such as ensuring that citizens' are able to have a say in matters that affect them in order for them to feel secure. Arguably, the implicit subjectification effects also include that these increased rights are primarily understood to be for the benefit of those citizencomplainants who enjoy good social conditions and higher education levels, as opposed to those who live in poorer social conditions with lower education levels.

Another example of the problem representation is also related to the notions held by the majority community of legal practitioners within the criminal justice system. The report states: 
The complainants' legitimate interests in having the state solve the case and assign punishment to the guilty person cannot be confused with a wish for revenge. The Committee's investigation shows that the complainant has interests in the case on completely different grounds than revenge. ... (Besides, doing so would be rather illogical, as having stronger rights does not increase complainants' possibilities for revenge.).

The Commission's report refers to Ertzeid (2005), who analysed the responses the Ministry of Justice received on the hearing process conducted on Robberstad's (2002) suggestions. In analysing the responses against affording complainants full party status, Ertzeid found that the responses were often grounded in the notion that affording complainants increased rights would entail 'an illegitimate legal acceptance of revenge', since complainants' motivations for participating in criminal trials are understood as being informed by feelings of revenge (Ertzeid, 2005, p. 110). The problem represented in the report excerpt above is the notion that strengthening complainants' rights could be used as a vessel for complainants' illegitimate feelings of revenge. In counteracting this argument, the Norwegian Commission emphasised the representation of the complainant as having legitimate factual and legal interests in the case. The subjectification effects of this argumentation entails that the complainant is represented as being guided by rational (as opposed to emotional) motivations. In the legal realm, emotions have long been understood as being subjective, partial and impervious to reason and therefore of having a destabilising effect on the rule of law (Bandes \& Blumenthal, 2012). This construction of the rational complainant motivated by factual and legal interest thus has the discursive effect of rendering complainants as legitimate actors in the eyes of the law. Conversely, those who might want to deny complainants increased rights on the basis that they might be able to exert their feelings of revenge through the criminal justice system are represented as harbouring illogical thoughts.

Another assumption underpinning the problem representation is that of complainants' secondary victimisation within the criminal justice system, as captured in the following excerpt from the report:

For complainants, [strengthening their rights] can also be of great importance for their sense of self-esteem. In cases concerning serious integrity violations, the strengthening of the complainant's status can be necessary to avoid that the criminal case is experienced as a new violation or a continuation of the violation.

Here, secondary victimisation is, partially or at least for some complainants, represented as being caused by a lack of rights or lack of empowerment; rights are also arguably represented to be equal to empowerment. This discursive reasoning is in line with certain knowledge strands within victimology, where 
some have argued that an important component in preventing or minimising secondary victimisation and in empowering complainants is to increase their procedural rights, particularly in cases of sexual violence and other serious integrity violations (Wolhuter, Olley, \& Denham, 2009).

So what are the lived effects of these policy suggestions? While all complainants are recognised as having legitimate interests in criminal cases, these interests are only converted into rights for specific groups of complainants, largely based on efficiency and cost arguments. Those represented as being most in 'need' of such rights are those who have suffered serious 'integrity violations', which 'cause major physical, mental and social harms' (p. 130). Per the recommendation of the Committee, complainants in the following crimes were afforded these new rights: sexual offences, serious physical violations, violations of restriction orders, forced marriage, violence in close relationships, human trafficking and genital mutilation (Norwegian Government Bill no. 11 [2007-2008], pp. 29-30). The lived effects of these laws hence affect complainants differently based on the type of crime they have been subjected to. Other than cases of serious physical violations, most complainants in these types of crimes are women and girls, sometimes with a foreign background and sometimes victimised by someone they know or are related to. The subjects produced, therefore, are largely women who have been subjected to sexual and other gender-based violence and who are to be empowered through these legislative amendments. As noted earlier, however, the majority of the Commission's members did not recommend giving complainants full party status. The report states that one member of the Commission, and the only representative from an NGO, thought that for her part, complainants should be afforded full party status. The report quotes her as saying that, despite this opinion, she is 'in doubt whether the Norwegian legal community is ready for such comprehensive reform' (NOU, 2006, p. 132).

\section{Denmark: Protecting vulnerable rape victims and preserving the rule of law}

In the Danish reports, contrary to the Norwegian report, the 'problem' is represented to be affording complainants participatory rights in court and stronger legal representation - particularly complainants in cases of rape and other sexual offences. The underlying assumptions are first that such rights would only serve to further victimise complainants, and second that such rights would jeopardise the rule of law.

The predominant representation of complainants in the Danish reports is that of traumatised rape victims (Betænkning, 2005, p. 51), which is also the main reference point in considerations of increased rights for complainants in general (Betænkning, 2006, p. 73; 2014, p. 66). This view is captured in the following excerpt:

[It should be] acknowledged that complainants in rape cases are in a very vulnerable position. This is because the rape victim, by the nature of the 
case, has to give testimony and be examined in relation to a very sensitive matter. ... Complainants in rape cases, who in principle are witnesses like any other witnesses, can easily come to feel that they are the ones being prosecuted. As a complainant in a rape case, it can therefore be particularly traumatising to go through the procedure.

(Betænkning, 2005, p. 51)

The crime of rape in this case is construed as particularly sensitive, and the criminal justice procedure is assumed to unavoidably retraumatise complainants. Arguably, both complainants and the crime of rape are implicitly construed as being incompatible with the criminal justice procedure. The effect produced by this problem representation is that complainants' subject positions become firmly rooted in both their primary and secondary victimhood. They are even described as easily taking on the subject position of the accused, which, in relation to the state, is considered to be in a very vulnerable position.

In the following excerpt, the SCACJ considers what might happen if CLs should have the right to ask complainants, and/or defendants and other witnesses, questions in court about other aspects of the case than only the compensation claim:

... this could influence the role of the CL in the process in an unfortunate way. This could - also unintentionally - lead to a more aggressive approach by the defence lawyer towards the complainant and their credibility. According to the Committee's opinion, it is against this background that there is good reason to exclude the CL from tasks that pertain to the evidence of the accused's guilt.

(Betænkning, 2005, p. 71)

Something like this would not be in the real interests of the complainant.

(Betænkning, 2006, pp. 73-74)

The discursive effect of this hypothetical scenario serves to warn against strengthening complainants' legal representation, as the assumption is that doing so would only lead to the further traumatisation of complainants, particularly in cases of rape. These subjectification effects construct defence lawyers as aggressive, and, given that this aggressive approach might also be unintentional, it also indicates that their aggression is unpreventable and, in a sense, uncontrollable. In turn, the complainants, and their credibility, are represented as the main targets for this aggressiveness. Given that rape cases are generally understood to be characterised by a lack of evidence, complainants' credibility is often understood to be their most important asset in a case. While one of the Danish reports states that complainants can have legitimate factual and legal interests in criminal cases (2006, pp. 68-69), indicating that complainants might therefore have a need for increased rights to protect those interests, the report introduces a new concept of complainants' 'real interests', as noted in the excerpt. The problem representation in this case is thus shaped by a paternalistic discourse in which complainants' 
real interests are to be protected from stronger legal representation, as such representation would only lead to the undermining of their credibility and them being subjected to further victimisation.

At least two factors are left unproblematised in this problem representation. First, as noted earlier, complainants' subject positions are represented as being akin to those of the accused in terms of their vulnerability in the criminal procedure. But while accused persons are afforded full party rights in criminal cases to defend themselves throughout the criminal justice procedure, that is not the solution presented for complainants. On the contrary, they are represented as being better protected if they lack such rights. Second, the defence lawyer's aggressive approach is represented as being uncontrollable but there is no mention of the role of the judge in this context in ensuring a fair court process. Therefore, the courtroom, which is a public place presided over by a judge, is represented as an uncontrollably hostile place for the complainant.

The second assumption underpinning the problem representation is that complainants' participatory rights and stronger legal representation could jeopardise the rule of law. In the Danish reports, one of the main obstacles to strengthening complainants' positions concerns the objectivity principle, according to which the prosecution authorities and the police are duty-bound to be impartial in their work, and that charges should only be issued if the prosecution authorities find that the charges will lead to a conviction (Betænkning, 2005, p. 64). The argument is that CLs cannot be expected to adhere to the objectivity principle, as their role is not to be impartial but rather to guard the individual interests of their clients (Betænkning, 2006, p. 72). The report further states that, according to the law, the prosecution authorities must make sure that:

... those who are guilty are held to account and [that] those who are innocent are not prosecuted. This principle applies to all aspects of the case, including when exercising particular party rights such as questioning witnesses. This arrangement is a central part of the rule of law and of society's protection against vigilantism.

(Betænkning, 2006, p. 72)

In this case, an implicit connection is effectively established between complainants' stronger legal representation and vigilantism (i.e. the objectivity principle serves to protect society against vigilantism), and affording complainants party rights is represented to be in conflict with the objectivity principle. One could argue that complainants' party rights hence are represented to possibly entail the undermining of the rule of law. The way in which increasing complainants' active rights is thought to jeopardise this fundamental principle of objectivity is portrayed as follows:

Such an arrangement could create lack of clarity in relation to the roles of the prosecutor and the defence lawyer, in that the complainant, or the CL, could appear as an additional prosecutor.

(Betænkning, 2006, p. 72) 
This can partly be perceived as a form of disparity, where there are 'two against one', and partly as a complication of the process where there would be two parties who would each in their own way pursue the same case. Such an arrangement could also, in the absence of the objectivity principle on the part of the complainant, lead to a shift in focus in terms of the presentation of evidence, whereby information that is not necessarily relevant for the criminal case will be sought or introduced.

(Betænkning, 2006, p. 73)

There is a nebulous and suggestive quality in the way in which a warning discourse is used to represent complainants' stronger legal representation as posing a potential threat to the objectivity principle. First, stronger legal representation for complainants is represented to possibly lead to lack of clarity in terms of the roles of legal actors, it could be perceived as a complication of the process, and it could lead to the submission of unnecessary evidence. Second, the equality/balance discourse is used to represent complainants' participatory rights as a destabilising agent - hence giving the appearance that there are two against one.

One of the benefits of conducting a comparative policy analysis is that such an analysis can reveal what remains unproblematised in a given problem representation. In the Norwegian report, for example, having stronger legal representation for complainants is not represented as going against the objectivity principle. In short, the objectivity principle is represented to be better protected if the prosecutor does not have to both pursue the case on behalf of the state and safeguard the interests of the complainant but can leave the latter to the CL (NOU, 2006, p. 103). In addition, the Norwegian report, drawing on Robberstad's (1999) critique of the 'balance illusion' discussed earlier, also does not represent complainants' participatory rights as undermining the accused rights, as the accused still has the same rights as before. The equality discourse is thus used to argue in favour of affording complainants' rights, since this is a matter of affording complainants some of the rights that accused people already have (NOU, 2006, p. 17 and 128).

To conclude, the Danish report notes that, given the ongoing developments in relation to strengthening complainants' positions, including the more progressive legislative developments in Norway, there is 'no reason to believe that the developments pertaining to the complainant have reached an end point' (Betænkning, 2006, p. 69). Arguably, this view indicates the committee's effort to hold on to a traditional legal arrangement while simultaneously realising that they are likely fighting a losing battle.

\section{Concluding remarks}

As I have shown in this chapter, a stark contrast is notable between the problem representations in the respective jurisdictions of Norway and Denmark. In Norway, the 'problem' is represented to be that complainants, particularly in 
cases of gender-based violence, lack participatory rights and stronger legal representation. In Denmark, the 'problem' is represented to be affording complainants such rights, particularly complainants in cases of rape and other sexual offences.

In Norway, the Commission's mandate indicated more clearly that political will existed to enact meaningful legislative changes to strengthen the position of complainants (and their next of kin) in criminal procedures. In Denmark, however, expert legal practitioners, largely representing the criminal justice system, were asked to assess if such changes were needed. The Norwegian Commission also included a representative from the NGO community and relied to a much larger extent on multiple knowledge sources, including international and extra-legal knowledge. Therefore, while the policy process in Denmark was largely shaped by traditional domestic legal knowledge practices, the Norwegian policy process also introduced 'subjugated knowledges' (Foucault, 1980, in Bacchi \& Goodwin, 2016), or knowledge types that challenge the centrality of traditional legal knowledge, including feminist-informed legal analysis, victimological knowledge and knowledge practices from other countries.

In both sets of policy texts, the main assumptions underpinning the problem representations are premised on the notions of secondary victimisation and the rule of law. But while these premises are similar, the reasoning draws on polar opposite conceptualisations, thus creating contrasting discursive, subjectification, and lived effects. Using a somewhat paternalistic discourse of protection, the Danish reports warn against affording complainants participatory rights and stronger legal representation, assuming that doing so would lead to the further victimisation of complainants and would undermine the rule of law. The Norwegian report, in contrast, includes an empowerment discourse, based on the assumption that having increased rights will counteract complainants' experiences of secondary victimisation and will ensure the ongoing rule of law, which otherwise might be at risk.

These markedly different problem representations produce two different subject positions for the complainant. The Danish reports represent complainants' subject positions as being rooted in their primary victimhood, where having increased rights, in a hostile courtroom, will only lead to their further victimisation. The only subject position offered for complainants is therefore that of the 'victim'. The discursive effects of the way in which the Danish reports represent increased rights for complainants as the 'problem' also produce a certain contradiction: complainants are represented as being too vulnerable to have stronger legal representation, while they would simultaneously pose a threat to the rule of law if such rights were afforded to them. The lived effects of these representations are that neither complainants nor their lawyers are allowed to become active agents during court procedures.

In the Norwegian report, by contrast, complainants are represented as being citizens first - rational yet vulnerable citizens who have been subjected to a crime and are in need of empowerment through having the right to guard their legal and factual interests during the criminal procedure. This subject 
position is therefore more nuanced and is, arguably, better captured by the notion of the 'victim-survivor'. It should be noted that the notion of the 'citizen-victim' has been problematised on the basis that many of those who have been subjected to crimes in society are people who are not citizens and are therefore particularly vulnerable and marginalised (Goodey, 2005, p. 139). However, when looking at which groups of complainants were afforded these increased participatory rights and stronger legal representation in Norway, then it is on the basis of the type of crime but not on the basis of complainants' citizenship status. Therefore, the lived effects of this problem representations does take this scenario into account. Arguably, however, the way in which the Norwegian report ties together social conditions, education levels and expectations for increased rights raises the question of whether these new rights are primarily conceptualised for certain groups of complainants, i.e. people living in good social conditions with higher education levels. We hence have reason to ask if and how these rights benefit people of lower educational and socio-economic status.

As noted above, in both Denmark and Norway, the main resistance to increasing the rights of complainants has come from the majority legal community within the criminal justice system. In Norway, the Commission stopped short of affording complainants full party rights in criminal cases, which the Commission's only NGO representative explained to mean that the Norwegian legal community was not ready for such reform. The resistance to complainants' rights in Norway is ongoing and is currently being shaped by the metadiscourses of 'effectivity' and 'legal certainty'. ${ }^{2}$ In 2014, the Ministry of Justice and Public Security appointed a commission to design a new Code for Criminal Procedure in order to address changes in the area of criminality, with a view to 'meet these challenges and facilitate an effective and legally certain settlement of criminal cases' (NOU, 2016, p. 93). The commission's mandate noted that, since the legal status and rights of complainants had recently been reviewed, the ministry assumed that there was no great need to revise those sections of the law. In their legislative proposal, however, the commission recommended several legislative changes to the rights of the complainant (NOU, 2016). During the hearing procedure following the publication of the commission's report, these changes were criticised for weakening the status and rights of complainants (e.g. Robberstad, 2017). The new code on criminal procedure has not been enacted to date.

\section{Notes}

1 The CL model was taken up in Norway in 1981, Sweden in 1988, Finland in 1997, and Iceland in 1999.

2 Legal certainty (rettssikkerhet) refers to the demand that court decisions be fair and predictable. Legal certainty is considered to be a central requirement for the rule of law. 


\section{References}

\section{General references}

Bacchi, C. (2009). Analysing policy: What's the problem represented to be? Frenchs Forest, NSW: Pearson Australia.

Bacchi, C., \& Goodwin, S. (2016). Poststructural policy analysis: A guide to practice. New York: Palgrave MacMillan.

Bandes, S. A., \& Blumenthal, J. (2012). Emotion and the law. Annual Review of Law and Social Science, 8, 161-181.

Betænkning. (2005). Betcenkning om forbedring af voldtcegtsofres retsstilling, no. 1458/ 2005 [On the improvement of rape victims' legal position]. Copenhagen: Danish Ministry of Justice, Standing Committee on Criminal Procedure.

Betænkning. (2006). Betcenkning om forurettedes processuelle retsstilling $i$ straffesager, no. 1485/2006 [On complainants' legal procedural position in criminal cases]. Copenhagen: Danish Ministry of Justice, Standing Committee on Criminal Procedure.

Betænkning. (2010). Reform af den civile retspleje VI: Behandling af forurettedes civile krav under straffesager (Adhcesionprocessen), no. 1522 [Reform of the civil procedure VI: The processing of complainants' civil claims in criminal cases (the adhesion procedure)]. Copenhagen: Danish Ministry of Justice, Standing Committee on Procedural Law.

Betænkning. (2014). Betcenkning om afhøring af forurettede før tiltalte i straffesager, no. $1549 / 2014$ [On the questioning of complainants before the accused in criminal cases]. Copenhagen: Danish Ministry of Justice, Standing Committee on Criminal Procedure.

Brienen, M. E., \& Hoegen, E. H. (2000). Victims of crime in 22 European criminal justice systems: The implementation of recommendation (85) 11 of the Council of Europe on the position of the victim in the Framework of Criminal Law and Procedure. Nijmegen, The Netherlands: Wolf Legal Publishers.

Christensen, J., \& Holst, C. (2017). Advisory commissions, academic expertise and democratic legitimacy: The case of Norway. Science and Public Policy, 44(6), 821-833.

Doak, J. (2005). Victims' rights in criminal trials: Prospects for participation. Journal of Law and Society, 32(2), 294-316.

Dullum, J. (2016). En ny offerposisjon? Om styrkede rettigheter for fornærmede i straffesaker [A new victim position? On stronger rights for complainants in criminal cases]. Nordisk Tidsskrift for Kriminalvidenskab, 103(3), 219.

Ertzeid, A. M. (2005). Hevn og straff: Studier av hevnenes strafferettslige legitimitet [Revenge and punishment: Studies on the legitimacy of revenge in criminal law]. Bergen, Norway: Fagbokforlaget.

Ertzeid, A. M. (2007). Kriminalitetsofrenes stilling [The position of victims of crime]. Nordisk Tidsskrift for Kriminalvidenskab, 94(3), 339-349.

Foucault, M. (1980). Two lectures. In C. Gordon (Ed.), Michel Foucault power/knowledge: Selected interviews and other writings 1972-1977 by Michel Foucault. Gordon, C., Marshall, L., Mepham, J. and Soper, K. (trans.). New York: Pantheon Books.

Goodey, J. (2005). Victims and victimology: Research, policy and practice. Harlow, England: Pearson/Longman.

Husa, J., Nuotio, K., \& Pihlajamäki, H. (2008). Nordic law: Between tradition and dynamism. Tilburg Institute of Comparative and Transnational Law working paper no. 2008/10.

Niemi-Kiesiläinen, J. (2001). Bortom tvekamp och inkvisition. Journal published by the Lawyers' Association in Finland, 138, 210-230. 


\section{Hildur Fjóla Antonsdóttir}

Nordic Council of Ministers. (2004). Nordisk seminar om offerets straffeprosessuelle stilling: Oslo, November 2002 [Nordic seminar on the victim's position in criminal procedures]. Copenhagen: Nordisk ministerråd.

NOU - Norwegian Official Report. (2006). Forncermede i straffeprosessen: Nytt perspektiv og nye rettigheter [Complainants in the criminal process: A new perspective and new rights], NOU 2006: 10. Oslo: Norwegian Ministry of Government Administration and Reform.

NOU - Norwegian Official Report. (2016). Ny straffeprosesslov [New laws on criminal procedure]. NOU 2016: 24. Oslo: Norwegian Ministry of Justice and Public Security.

Robberstad, A. (1999). Mellom tvekamp og inkvisisjon: Straffeprosessens grunnstruktur belyst ved forncermedes stilling [Between duel and inquisition: The basic structure of criminal procedure in light of the role of the complainant]. Doctoral thesis. Oslo: University Press.

Robberstad, A. (2002). Kontradiksjon og verdighet: Komparativ fremstilling av forncermedes stilling $i$ de nordiske land, med sikte på forslag om styrking av forncermedes rettigheter i straffeprosessen [Contradiction and dignity: Comparative analysis of complainants' position in the Nordic countries, with suggestions to strengthen complainants' rights in the criminal procedure]. Report. Oslo: Norwegian Ministry of Justice and Police.

Robberstad, A. (2014). Bistandsadvokaten [The complainant lawyer] (3rd ed.). Oslo: Universitetsforlaget.

Robberstad, A. (2017). Hearing statement, 2 June. www.regjeringen.no/contentassets/adda de5d609e4683a3f6217304df9fc9/annerobberstad.pdf?uid=Anne_Robberstad

Summers, S. (2007). Fair trials. Oxford, UK, and Portland, OR: Hart Publishing.

Wolhuter, L., Olley, N., \& Denham, D. (2009). Victimology: Victimisation and victims' Rights. London and New York: Routledge-Cavendish.

\section{Laws}

Amendment to the Danish Administration of Justice Act, no. 558, 24 June 2005

Danish Administration of Justice Act

Finnish Act on the Openness of Government Activities 621/1999

Finnish Criminal Procedure Act 689/1997

Icelandic Laws on Criminal Procedure 88/2008

Norwegian Government Bill no. 11 (2007-2008)

Swedish Act on Public Access to Information and Secrecy 2009: 400

Swedish Code of Judicial Procedure 740/1942 


\title{
10 Othering the rapist \\ Rurality, sexual violence and the Bjästa case
}

\author{
Lucas Gottzén and Anna G. Franzén
}

\section{Introduction}

Sweden has undertaken major efforts to combat sexual violence, particularly since the 1990s, when society came to view such violence as an expression of lack of gender equality. Since that time, the judicial protection of rape victims has strengthened, and society's condemnation of men's sexual abuse has toughened. Today, Sweden enjoys relative political consensus on the issue and, as part of gender-based violence, sexual violence has been central to several governments' gender-equality policies, regardless of political colour. For instance, the commission report that served as the basis for new sexual offences legislation described ending sexual violence as pivotal for gender equality: 'Our proposal to change the sexual offences legislation ... is an important step to a more gender-equal society' (Statens offentliga utredningar, 2016, p. 419). The commissioners argued that stricter laws and preventive work in schools were key in combatting sexual abuse:

If the proposal is implemented and followed by educational interventions and information campaigns in schools and in society, we estimate that the proposal - at least in the long run - may plausibly lead to changes in norms and behaviour related to sexuality and sex so that sexual offences will decrease. ... Our proposal to change the crime designation from rape to sexual assault may also improve equality between men and women.

$$
\text { (pp. 419-420) }{ }^{1}
$$

While sexual violence has long been targeted through legislation and victim support, gender-based violence policies have recently started to endorse universal prevention: that is, health-enhancing activities that address a general population or a specific age group and in which the activities are carried out prior to the violence. Sweden's Minister of Gender Equality has particularly promoted preventive work that involves men and boys and that targets gendered norms that justify violence (Government Offices of Sweden, 2016), including the Mentors in Violence Prevention (MVP) programme, which was developed in the United States and has recently been implemented in many Swedish secondary schools. 
Such legislative and interventive efforts in combating sexual violence are part of a longstanding tradition of progressive politics and social engineering that have been decisive in moving Sweden from being a poor, unmodern and primarily rural country on the global periphery to becoming something of a beacon of modernity. Along with parental-leave legislation, gender-based violence policies have been particularly central in presenting Sweden as 'a gender-equal paradise' and Swedish men as the most gender-equal men in the world (Gottzén, 2016, p. 165). As a result, the prevalence of the abuse of women appears as 'an anachronistic remnant' of traditional Swedish society and 'an obstacle for the modern regime we already live in' (Wendt Höjer, 2002, p. 179).

While combating sexual violence is a positive goal, the nation's genderequality policies have had a few unintended exclusionary consequences. Since gender equality is typically seen as being more or less ingrained in the Swedish character, acts of sexual violence committed by ethnic minority groups are often considered cultural traits and signs of a lack of Swedish values (Bredström, 2002). In contrast, acts of sexual violence committed by ethnic majority men tend to be regarded as either a consequence of individual psychopathology or of socioeconomic circumstances (Gottzén \& Jonsson, 2012).

We analyse in this chapter how sexual violence is discussed in the schoolbased MVP programme. In classroom discussions about rape and bystanders' responses to sexual violence, people recurrently distinguished between 'us' and the other. Rather than noting a primary connecting of rape to ethnic minorities, however, we identified several othering processes in relation to rurality, including both the male perpetrator (in this particular case) and the community in which he resided. Such othering, we argue, is related to a history of thinking of the countryside as a peripheral place excluded from the modern urban Swedish project; this outlook then enables the projection of negative affect towards rurality.

In the following sections, we provide a brief overview of current academic debates about rural violence; we then discuss a documentary film about a rape case in a town in northern Sweden and the media debate about the case, both of which MVP uses in the classroom. We detail how, when students and teachers discussed the case in the classroom, they distanced themselves from the community's responses to sexual violence. We then discuss how the othering works through an affective politics of disgust.

\section{Sexual violence and rurality}

Rural violence has emerged as an important field of inquiry over the last few decades (for overviews, see Edwards, 2015; Hall-Sanchez, 2016; Sandberg, 2013). This research has shown that physical and sexual violence is just as common - if not more common - in rural areas as it is in urban areas (Edwards, 2015), and that such violence has specific rurality-based characteristics. For instance, studies have demonstrated that women in rural areas are 
particularly affected by socioeconomic disadvantage and spatial and social isolation, that small communities have a lack of anonymity, and that the countryside is characterised by 'rural patriarchies' that provide social and emotional support to men who are violent towards their partners; all these circumstances may exacerbate the victims' vulnerability (DeKeseredy \& Schwartz, 2009). By highlighting the specific problems rurality imposes on victims of violence, such research has questioned notions of the countryside as an idyllic and peaceful place.

While acknowledging the importance of this scholarship, Sandberg (2013) has pointed out that this work tends to reproduce stereotypes of rurality and rural gender relations. In particular, such studies reinforce perceptions of rural localities and inhabitants as deviant, which may further marginalise rural victims of violence. This 'othering of rurality' corresponds with a common portrayal of the countryside that co-exists with the notion of the rural idyll: the countryside as a risky place characterised by racism, sexism, poverty and social problems (Stenbacka, 2011). Within this discourse, the countryside is often conceptualised as an unmodern and stagnant place. Similarly to sexual violence in Swedish gender-equality policies, the countryside becomes tied to the past and differentiated from a progressive urban centre. The north of Sweden in particular is often portrayed as a 'space of exception', a traditional and undeveloped space, in contrast to an otherwise modern nation (Eriksson, 2008).

In order to avoid reinforcing stereotypes of rural inhabitants, exploring the specific intersections between rurality and gender that may cause violence and produce place-specific vulnerability is insufficient; it is also necessary to deconstruct these categories, in particular clichés about rurality (Sandberg, 2013). Following this intersectional approach, in this chapter, we argue that simply highlighting the particularities of a place or group may enhance stereotypes and support the belief that sexual violence is only to be found among certain groups, or that certain groups support such violence more than others. Sexual violence could thus lead to hierarchy reproduction when people argue that such violence is an essential expression of particular groups and places. This notion is particularly important when discussing rural violence, given how both the countryside and violence are frequently tied to notions of unmodern and deviant masculinity. Sexual-violence prevention policies that are unconnected to the intersectional challenges of rape may reproduce ethnic, spatial and other hierarchies that continuously place rape as a crime only committed by other men in other places.

\section{Method}

This chapter draws on a larger ethnographic study of the Swedish implementation of the MVP programme that was conducted in 2016-2017. ${ }^{2}$ The goal of MVP is to prevent violence among boys and men. The programme was originally developed in the United States (Katz, 1995) and has recently been reworked to fit a Swedish setting. ${ }^{3}$ Central in the prevention programme are 
(1) the use of a bystander approach, which entails a focus on witnesses or bystanders of violence, rather than primarily the offender; (2) the existence of gender and masculinity norms and how they relate to violence; and (3) a focus on the continuum of violence, a perspective that illustrates how 'mild' violence is connected with, and might lead to, severe violence. The programme thus aims to prevent violence among boys by supporting bystanders in recognising violence at an early stage and intervening before it escalates into severe violence, and to alter problematic gender norms that enable men's violence, with a focus especially on sexual violence. School teachers undergo a three-day leadership training course and then conduct the programme with students at their schools, using a detailed MVP manual. The programme consists of seven two-hour lessons focussed on different subjects regarding the bystander perspective and issues related to gender and violence, specifically sexual violence. The lessons consist of teacher-led discussions and exercises centred on gender and violence, including storytelling about leaders' experiences with violence, hypothetical examples of violence, lessons on how to intervene safely as a bystander, and discussions about well-known cases of violence, such as the Bjästa case (the subject of this chapter).

The data consist of participant observations of leadership training and supervision as well as group interviews with teachers and students. In total, we interviewed 14 teachers and 26 students from five different schools, all in medium-size cities in Sweden. In addition, we conducted video-based observations of interactions in two classrooms throughout one semester (approximately 25 hours): one in a lower secondary school and one in an upper secondary school. The present study may be understood as an ethnographic case study in which we aim to 'follow the thing' (Marcus, 1998, p. 91). The 'thing' in this case is not so much a material object or a geographic location as a case of sexual assault in Bjästa, a town in the north of Sweden where a teenage boy who was convicted of rape received the support of his community. We therefore explore how people have discussed and felt about this 'thing' in a variety of settings, including a documentary, a motion picture and the media debate about the Bjästa case; we also examine how MVP used parts of the documentary about the rape to discuss sexual violence, gender and bystander responses.

The interviews and observations have been transcribed and coded, which helped us to identify recurrent themes in the talk about violence in general, sexual violence and gender. One such recurrent theme that we found throughout the whole corpus of the data was that of othering when discussing violence, and especially men's sexual violence. In the following section, we focus on the specific type of othering that we found to have occurred during classroom discussions about the Bjästa case. We have chosen this case since it is a particularly clear example of the recurring phenomenon of othering. We have also chosen the Bjästa case since it emerged as a recurring topic during the interviews; both teachers and students described the case as being particularly useful and interesting for discussion. 


\section{The documentary and the debate}

In the spring of 2009, a 15-year-old boy raped a 14-year-old girl in a school bathroom in the town of Bjästa in northern Sweden. The boy admitted to the assault and was sentenced in the district court and later in the court of appeal. A documentary titled The Second Rape (Swedish: Den andra våldtäkten), which aired on Swedish national public television (Sveriges Television, 2010) the following year, tells of how the community turned against the girl and supported the offender. Few believed the victim, who is called Linnea in the documentary, even though her story was confirmed in court.

In the documentary, the boy, called Oskar, is portrayed as popular. Because he is well liked, most people around him argue that he could not have committed the sexual assault. According to the reporter in the documentary, 'Everybody describes Oskar as a social boy who doesn't have any problems getting girls. Nobody understands why he'd commit a rape in the school bathroom'. In interviews with youths and adults from the town, few believe Linnea but rather argue that she is lying or distorting the truth. They contend that she has reported him because she wanted revenge, as she was disappointed that she had been unable to have a relationship with him. The locals who are interviewed claim that her information is fuzzy and contradictory. In general, her picture of Oskar is incongruent with theirs.

The events seem to have engaged large parts of the town. 'Rumours about what happened spread like wildfire in the community, and nobody believed Linnea', the reporter says. Bjästa's small size is self-evident background in the documentary. The town is repeatedly described as a small community, for instance, when the journalist introduces the town in the documentary as 'the small town of Bjästa, outside Örnsköldsvik'. Later he portrays the town as gossipy and comments that 'the tittle-tattle in Bjästa has grown to truths online'. In the documentary, the rumours are said to have been caused by the combination of a small town and the power of social media. Many people joined social media groups whose aim was to free Oskar from guilt, while they depicted Linnea as being promiscuous: 'She's called a tramp and a whore on the internet'. Her friends turned against her, and she felt increasingly threatened.

The climax of the documentary is the school graduation held in the local church, where the priest allows Oskar - who is under a restraining order at this point and has been moved to another school - not only to participate but also to hand out roses on stage to his old classmates and teachers. The attendees applaud him for what they consider a gesture of reconciliation. (Linnea dared not participate in the graduation, however.) The same night, Oskar goes on to rape another girl, a crime that he was later also convicted of. When the journalist confronts the priest about the graduation, he argues that it was really strong that he managed to' appear at the ceremony and that his doing so 'was a demonstration for human dignity'. The priest does not appear to think about Oskar's restraining order but argues that he is always welcome, sentenced or not. When asked if he has reflected on Linnea's situation, he falls silent. As 
a consequence of the bullying and the rumours, Linnea is then forced to move from the small town to the larger city of Stockholm.

After the documentary, the events in Bjästa became national news. The priest and the school were criticised for not supporting the assaulted girls. But the town itself was also denounced. While the documentary had highlighted the hate and the threats the victims of sexual violence had experienced from the people of Bjästa, the perpetrator and the town now became targets of hate and disgust. Oskar and his family were threatened, which caused the police to have to provide special protection. Another boy in the same school was also threatened, since he happened to have the same first name as the perpetrator's fictional name, Oskar.

A newspaper article published a few days after the documentary's airing described the responses from the town:

The inhabitants of Bjästa agree: they don't deserve the hate the entire country has addressed to the community. ... People are angry at the media; they think the media has turned Sweden against the village. The harassments have not ended, just taken a new course. 'Shame on you, Bjästa', 'Burn down Bjästa'. Every day, new protest groups against Bjästa are started on Facebook. The hate mail and the threats never seem to stop. Hell broke loose for many villagers when the documentary was shown last Wednesday. (Sundén Jelmini, Paulin, Nilsson \& Baltscheffsky, 2010, p. 6)

In the article, youth from Bjästa argued that the town had become a 'disgrace' but that it did not deserve its bad reputation. 'They tar everyone from Bjästa with the same brush', one boy told the newspaper.

At the end of each year, the Swedish Language Council presents its list of the 'Words of the Year', a list of words that are either new or have emerged in the last year and have become popular. In December 2010, one of the council's new words was 'bjästa', or rather 'doing a bjästa', which the council defined as 'siding with a perpetrator of a crime and bullying the victim [after the events in Bjästa, where many supported a rapist and bullied the victim]' (Swedish Language Council, 2010). Following this announcement of the new word, regional radio channel P4 Västernorrland asked, 'What does it mean for a small community to get such a deprecatory label?' Municipal commissioner Glenn Nordlund argued that 'for us, the event is serious, as it is troublesome in itself - for the parties, of course, but also for the community. We don't need a word to remember [us by]'. The reporter asked him, 'Do you think Bjästa will ever get rid of this label?' Nordlund responded, 'It's been difficult all the same. Now we'll get a label that will probably follow us for a long time' (Sveriges Radio, 2010).

Bjästa continued to be a deterrent example of how a community could turn against a rape victim (e.g. Wennstam, 2015). The motion picture Flocking (Flocken in Swedish), which was based on the events, premiered in 2015; the film won several Guldbagge awards (Sweden's highest award for filmmaking) 
as well as a Crystal Bear at the Berlin Film Festival. The film's director, Beata Gårdeler, saw the film as an example of how 'regular guys' could use sexual violence: 'We've created a picture of what a rapist looks like - he's either an ugly geezer in the woods or a gang of migrants - but the most common is that it's a young guy without a criminal record' (Bendjelloul, 2015, p. 4).

Gårdeler argued that what happens in the film could happen anywhere: 'I don't think that it could only happen in a small village or that [the townspeople] in any way are more stupid or evil [than others], but that it can happen anywhere' (Sveriges Radio, 2015). Yet she also emphasised that there was something specific to small towns such as Bjästa. She saw the town's strong community bonds - its herd mentality - as crucial for the events to have happened:

I grew up in a small community in the north of Sweden, where I experienced that the social patterns felt old-fashioned, and norms were strong. Together with the growing importance of social media, this could make [the risk of] assaults against a person become even greater today.

(Gårdeler, 2015)

The film created controversy. But this time it was not the stereotypical portrayal of Bjästa that people discussed, but rather the director's moral responsibility when making a movie based on a true story. Linnea's family was critical of the film, arguing that it resembled the original events too much, while it portrayed the raped girl's mother as an alcoholic and her father as incestuous. The family argued that these fictive parts could be perceived as real. 'It's like a third rape', the mother wrote in an op-ed piece in the newspaper Aftonbladet (Granlund, 2015).

\section{The Bjästa case in the classroom}

According to the MVP programme manual, the rationale behind using the Bjästa case in the Swedish adaptation of the programme was to provide an example of severe sexual violence that everybody can take a stand against. The aim was also to give the participants insights into what rape could look like and to realise that it is easy to contribute to spreading rumours. Another goal was to clarify bystanders' responsibility by showing how 'easy it is to do something, good or bad' (Men for Gender Equality, 2014, p. 49). The manual further describes the Bjästa case as potentially fruitful since it highlights the role of social media:

... first, [the case includes] a girl people don't believe. People use Facebook to spread hatred of her. The boy gets support from his friends and the community. Then he commits another rape, and eventually people turn their hatred towards him. All these components are interesting, but Facebook's role in the case is relevant, considering young people's use of social media. 
In the interviews, the teachers recurrently pointed out that Bjästa was an interesting and useful case. They said the case was immensely popular among the students, as it affected them and spurred much discussion in the classroom. They considered the case to be among the exercises in the entire programme that went particularly well:

I'm thinking that what can be difficult sometimes is ... to get the discussion going: breaking the ice and getting everyone to start talking. But when it came to [talking] about the Bjästa rape, that really got the whole class going.

(Male teacher)

The other teachers in this focus group agreed that the film clippings were captivating and said that the students wanted to see the entire documentary. The students were critical of how the town had responded to the rape, and they particularly considered the priest to be 'crazy'. The teachers recalled some of the students' reactions: 'It was almost as if they were a mob themselves'; 'They were thinking, "Oh my god, such idiots!"; 'That priest!'; 'That's how they are in Bjästa?'; and 'Everyone in Bjästa must be an idiot'.

During an in-service training day, a female teacher from another school also discussed the Bjästa case:

I was also thinking about those video clips about Bjästa: our students really got wound up. Then you really would've wanted to be able to show the whole documentary, and I really wish we could've had those extra 40 minutes to keep discussing.

A male teacher responded:

They made so many mistakes [in Bjästa]. You want to explain to them [when the students say things like] 'But it's because they're totally crazy in Bjästa', and you're just like, 'No, that's not how it is'.

In our classroom observations, the students were clearly intrigued and liked to discuss the case, but the stereotypical descriptions of the town found in the media after the documentary had obviously surfaced in the classroom as well. In the following paragraphs, we analyse the interactions in the upper secondary school, where the Bjästa case was discussed during the second lesson of the programme. During the introduction of the case, one of the two teachers immediately brought the students' attention to the size of the town: 'Has anyone heard about the Bjästa case?' Several of the students pointed out that they had not heard about it. The teacher therefore started what could be described as a collaboratively built narrative by accounting for the events after the rape by emphasising that Bjästa was a small and remote town: 
... [The town] was very hyped up at the time. A whole lot was written in the papers about what happened there. Then there was this documentary. There was a fourteen-year-old girl, and Bjästa is located up in ... wait, where is it now? In Övik, right?

Not completely sure of where the town was located, the teacher sought confirmation from the other teacher and then emphasised the size of the community. 'Yeah, so a small town, yeah. Örnsköldsvik is small', the teacher said, smiling. 'Bjästa is located [near Örnsköldsvik], so you can imagine [what] a tiny, tiny place that is'. Framing the Bjästa case as taking place in a small town is not suggested in the MVP manual, which does not mention the size of the town; this discussion was rather something that emerged in the classroom when the participants engaged in the subject and, as one teacher put it, got 'wound up' in their discussions.

After the teacher had provided some more context to the case, specifically about Oskar being taken in for interrogation, they moved on to describe how rumours about Linnea had begun to spread in the community. Again, the teacher emphasised how small the town was and related its size to how the rumours had begun to spread:

And now the rumours begin to spread. Just imagine, a small community, and the rumours start going around. And the rumours are that Linnea is lying and that Oskar is innocent, and they say that Linnea is, so to speak, promiscuous and that she's reported the rape because she wanted to get back at this guy because he didn't what to be in a relationship with her.

The teacher's continued narrative of the events built on how unlikely it was that this could have happened in the first place: 'And the adults in Bjästa as well that's what you think is so strange in this documentary, that the adults also were on his side'. A girl in the class raised her hand and asked about when this had all taken place; a recurrent theme was how people described Bjästa as unmodern, which was something the class returned to later in the discussion. The teacher answered, 'It was 2010, so it was six years ago'.

At this point of the introduction, the teachers (following the instructions in the manual) showed two short video clips from the documentary about the rumours that spread after the initial report and Oskar's hearings, and then how Oskar admitted to the rape in his third interrogation - and how people in the town still did not believe him to be guilty. The students' questions homed in on how incredible it was that they would not have believed Linnea at this point. The other teacher continued to explain how the rumours spread, saying that they 'spread like crazy online as well'. And again, the size of the town and what was unique to small towns appeared in the account: 'Even if it's a small town where you might also hang out like' this, they said, gesturing with their arms in what seemed to be a display of physical proximity. One of the teachers continued: 
Since it's a small community, you see each other [frequently]. But so, so, so much hatred started to spread towards this Linnea online as well. And groups started to form that really were, like, against her and that believed in him.

The teachers went on to describe how Oskar raped another girl after the school graduation and that, unbelievably, the people of Bjästa still did not turn against him. They showed a video clip of the priest in Bjästa who talked about how great he thought it was when Oskar showed up at the graduation and brought flowers to the other students, and how he felt sorry for Oskar under the circumstances. At this point in the video, many of the students in the classroom burst into loud guffaws, particularly when the priest said 'poor guy - and the girl too'. The teacher commented:

Exactly: this is the reaction you get, 'cause of course you think he's totally crazy, this priest; he doesn't seem to know anything, you know. Then we might not know exactly how the journalists have cut and angled it, and you know how it is ... but this wasn't good, plainly put. This was a big failure on the priest's part.

The students' disbelieving laughter, together with the teacher's confirmation of how 'totally crazy' the priest seemed, continued to present the events of Bjästa as beyond belief and the townspeople, specifically the priest, as irrational and even pathological. Building on this notion, a girl in the class returned to the question of when this had all actually happened: "Was this really 2010? "Cause it seems as if they were more old-fashiony?", The teacher answered, "Yeah, but it was more old-fashioned then, you know'. Again, the girl pointed out that the events seemed old: 'Yeah, but still, it feels kinda like the '90s when you see them'.

The students were then asked to discuss in small groups and were given a few questions to guide their discussions: their general thoughts about the case, how cases such as this could have happened and how people could have become fixed on the idea that Oskar was innocent and that the two girls were lying. After several minutes, the teachers encouraged the students to share their thoughts with the whole class. The first student to speak returned to the description of the priest: 'The priest seems to be totally stupid, but really, he interprets [the case] in the same way as the whole village does anyway, so I mean, it's not just him ... it's the whole village in that case'.

After some more discussion, the students returned to the small groups and talked about the role of social media in the spreading of rumours, as well as how the online bullying of the girls could have been stopped. The students had a lively debate for a while and then shared their thoughts with the class. At first, their comments centred on Facebook being a channel for bullying and allowing large numbers of people to join in, and on how strange they found it that adults would participate in the bullying as well. Then, as this section of the class was beginning to near its end, their attention was once again directed towards the size of the town, this time by a female student. 
'But in such a small town it's also easy for everyone to follow the trend, that no one dares ...' She then turned to the class and asked, 'But how small was the municipality?' As a response, the teachers introduced the town's tininess as a laughing matter, saying that Bjästa was located outside of Övik, and that perhaps 20,000 people lived in Övik; the other agreed: 'And Övik is pretty small, you know', and laughed. The girl did not appear satisfied with this answer, however, and asked for more detailed information about the size of the town. 'We'll have to google it', one of the teachers responded. Moments later, a boy in the class googled the question and soon proclaimed that in '2010, one thousand eight hundred and eight people lived in Bjästa'. One of the teachers asked, 'In Bjästa?' as if in disbelief. At this point, the entire class burst into loud laughter. The students and the teachers laughed together, and many talked excitedly to each other, repeating the numbers of thousands of people, seemingly discussing the size of Bjästa and other towns. Someone loudly exclaimed, 'One thousand and eight!?' and was corrected by one of the teachers ('one thousand eight hundred and eight - almost two thousand'). The teacher exclaimed, 'Yeah, get that!', confirming how incredibly tiny Bjästa is.

The chatter and laughter in the room continued for a few moments before the two teachers suggested that they take a ten-minute break. On this note, the class ended - one where the entire class together had enjoyed laughter about how tiny Bjästa is. The laughter in this situation might be understood as another way to increase the distance between the 'us' in the classroom and the 'other' in Bjästa and to provide an implicit, yet clear, answer to the question of how events such as those that took place in Bjästa could have happened. In a sense, the case was now closed, the students asked no more questions about the events (or the reasons they occurred) and the class moved on to a different subject after recess.

While the intention with the exercise was to make the students reflect on the role of social media, students and teachers alike primarily focussed on the small size of Bjästa, which they characterised as a place where 'everybody knows each other' and where rumours spread quickly. They argued that social media enhanced the gossip, but any comparisons between Bjästa and how hearsay may function in the school or the city where the participating students lived were absent in the classroom interactions. Instead, the participants repeatedly portrayed Bjästa as a different place, a space of exception (cf. Eriksson, 2008). While discussing the case, they did not consider sexual violence to be something that characterised rurality, but they did make the townspeople's responses to the rapes intelligible by Bjästa's tininess and by its community bonds, which they assumed to be strong.

\section{Discussion}

Until now we have discussed how Bjästa became a space of exception by its rural qualities, both in the media and in the classroom, particularly its reputation 
as a small town with a strong sense of community. In the following, we will add a further perspective in order to understand why the case discussions ended up focussing almost solely on rural deviance rather than on the role of social media. We will do this by focussing on the affectivity of othering processes, particularly by arguing that the Bjästa case is instructive of how negative affect circulates.

Cultural theorists such as Ahmed (2004), Anderson (2014) and Brennan (2004) have posited that affect is completely cultural while also being experienced in our bodies. We discern feelings in our bodies, but affect is also something in between us, as a relational experience. We get angry at somebody, we feel guilty for someone. We are ashamed when we see ourselves through the eyes of others. We sense the atmosphere when entering a room, or the hope in a political rally (Anderson, 2014). Affect 'transmits' (Brennan, 2004). We are affected by others' feelings, we are moved and the affective expressions of others cause us to feel and act in different ways. Another way to put this is to say that affect 'circulates' (Ahmed, 2004); it is contagious and moves between bodies. But as it circulates and comes in contact with certain bodies, affect may be channelled into specific emotions and - due to these emotions' history of associations - stick more easily to certain bodies; some figures may cause more disgust and revulsion than others (Ahmed, 2004). It follows that rapists and batterers of women are 'sticky' figures that may be attached to the men in their proximity. If someone has used physical or sexual violence, there is a greater risk that he will be regarded as an undesirable or 'shady' figure and hence becomes the target of hate and loathing (Gottzén, 2016, 2017), just as Oskar faced disgust after the documentary.

Bjästa is an interesting case, as it demonstrates how negative affect may spread and get stuck to different bodies. The case shows that affect is not simply something we experience in our bodies, but that it also transmits between us. We first find affective transmission between the perpetrator and the victim in the school bathroom: an event that, according to the documentary, was filled with both sexual arousal and fear. What initially seemed to be mutual desire changed as Oskar used force to get sex; his assaultive bodily confrontation made Linnea afraid and influenced her immobility. This scenario speaks to how encounters between bodies not only enable different affective states - thus making us feel something - but also channel our capacities to act (Deleuze, 1988). This situation also became evident when rumours later started to spread and the community became disgusted with the victim, which restricted her and finally forced her to move from the town. Meanwhile, the community supported and cared for the offender. Oskar seemed too nice and too popular to have been able to commit such a sexual offence. According to the community, rape was not something that happened there, or something that 'our' boys did. This outlook corresponds with the work of Wennstam (2015), who has pointed out that in cases where perpetrators of sexual violence receive social support, their relatives and friends have difficulty believing that 'their boy' is capable of such a crime. 
Affect also transcends beyond the human and appears through digital spaces and their specific affordances. In the Bjästa case, the screening of the documentary enabled somewhat of an affective twist. While people had at first directed their disgust towards Linnea, Oskar later became the target of online hate. People also projected their contempt onto others, particularly the priest. But what is perhaps most distinctive is that the abhorrence became attached to the town itself once Bjästa became a metonym for defective responses to sexual violence and the community the exemplar par excellence of a 'herd mentality' that then enabled derisive comments about the place. Affect may thus not only stick to bodies but may also envelop specific places, as affect is an encounter between both human and non-human bodies and materialities (Anderson, 2014; Deleuze, 1988). It seems reasonable to see that the disgust stuck to Bjästa in light of cultural perceptions about rurality and small villages in northern Sweden and its inhabitants (Eriksson, 2008; Stenbacka, 2011). People explained the villagers' handling of the rapes by Bjästa's small size and its strong sense of community. In all these affective moves, sexual violence was considered as something that happened elsewhere. Notions about rurality served as a backdrop in the documentary, as articulated in the news coverage and in the reactions on social media afterwards; such notions were also a theme in the film Flocking.

Disgust and negative affect circulated further. While MVP's intentions of using the Bjästa case was to cause students to reflect on social media usage, both the students and their teachers were occupied with the fact that Bjästa is a small community where everyone knows each other and rumours spread quickly. People argued that social media platforms such as Facebook contributed to this situation, but they made few comparisons between Bjästa and the students' own schools and cities. Even though the MVP manual emphasises that the violence and responses to the violence in Bjästa could have happened anywhere, those in the classroom portrayed the rapes and the bystanders' responses to the sexual violence as exceptional. To them, such violence simply could not have happened in their suburb, in their school, in their city, but only in the 'tiny village' out there, distinguished by its herd mentality.

Distance thus seems to be a crucial factor in affective responses to rape, as responses to violence in general include both relational and spatial positions (Gottzén \& Sandberg, 2019). When perpetrators are close to us, when they are familiar, we find it difficult to believe that they could do any harm. When they are more distant - for instance when we learn about them through news and documentaries - they become unintelligible strangers who are radically different from us (Gottzén, 2013). They, and those who support them, evoke disgust. This scenario reflects a more general tendency in Sweden's policies and media debates on violence, where people tend to view sexual violence as something that characterises other men (Gottzén \& Jonsson, 2012). In the classroom discussions examined in this chapter, sexual violence - and particularly the 'negative' bystander responses to abuse, where the community gave the perpetrator social and emotional support and bullied the victim - not only 
appeared to be an unsolicited reaction but also was something that characterised rurality: a rurality that in many ways seems to be stuck in an unmodern and uncivilised culture.

In this chapter, we have shown that discussing sexual violence is a matter of affect. The designers of the MVP programme appeared to have been aware of this notion when they addressed participants as bystanders rather than possible victims or perpetrators. This approach is generally thought to avoid making boys feel collectively blamed for sexism and abuse and thus reluctant to engage in interventions. Yet, our findings from this case suggest that sexual violence still became a hot topic that had an impact on the participants. In delicate situations such as these, clichés about rapists and rural towns, and the negative affect that coalesces with such figures and places, become resources that teachers and students can use to approach the conundrum of violence by placing both sexual violence and problematic bystander responses in a rural space of exception.

\section{Notes}

1 The translations in this chapter (all from Swedish to English) have been slightly edited for clarity in English.

2 The study was part of an evaluation of the MVP programme financed by the Swedish National Agency for Education. The study has been approved by the Regional Ethical Review Board in Uppsala (ref. no. 2016/067).

3 The US version of the programme was originally aimed at young men in sports programmes. The Swedish version of the programme has been transformed for use with all students in school, and the connection to youth sports has been removed.

4 'Övik' is a colloquial abbreviation for Örnsköldsvik. Örnsköldsvik is a city, but also the name of the municipality that includes Bjästa. The term 'municipality' (Swedish: 'kommun') is widely used in Sweden.

\section{References}

Ahmed, S. (2004). Cultural politics of emotion. Edinburgh: Edinburgh University Press.

Anderson, B. (2014). Encountering affect: Capacities, apparatuses, conditions. Aldershot, UK: Ashgate.

Bendjelloul, W. (21 August 2015). Filmen handlar mer om rädslor än om våldtäkt. Dagens Nyheter, p. B4.

Bredström, A. (2002). Maskulinitet och kamp om nationella arenor: Reflektioner kring bilden av 'invandrarkillar' i svensk media. In P. de Los Reyes, D. Mulinari, \& I. Molina (Eds.), Maktens (o)lika förklädnader: Kön, klass \& etnicitet $i$ det postkoloniala Sverige (pp. 182-206). Stockholm: Atlas.

Brennan, T. (2004). The transmission of affect. Ithaca, NY: Cornell University Press.

DeKeseredy, W., \& Schwartz, M. (2009). Dangerous exits: Escaping abusive relationships in rural America. New Brunswick, NJ: Rutgers University Press.

Deleuze, G. (1988). Spinoza: Practical philosophy. San Francisco, CA: City Lights Books.

Edwards, K. M. (2015). Intimate partner violence and the rural-urban-suburban divide: Myth or reality? A critical review of the literature. Trauma, Violence, \& Abuse, 16(3), 359-373. 
Eriksson, M. (2008). (Re)producing a 'peripheral' region - Northern Sweden in the news. Geografiska Annaler: Series B, Human Geography, 90(4), 369-388.

Gårdeler, B. (2015). Flocken: Beata Gårdelers omskakande Kristallbjörnen-vinnare! Triart. Retrieved from www.triart.se/filmer/flocken/

Gottzén, L. (2013). Encountering violent men: Strange and familiar. In B. Pini \& B. Pease (Eds.), Men, masculinities and methodologies (pp. 197-208). London: Palgrave Macmillan.

Gottzén, L. (2016). Displaying shame: Men's violence towards women in a culture of gender equality. In M. Hydén, D. Gadd, \& A. Wade (Eds.), Response-based approaches to the study of interpersonal violence (pp. 156-175). London: Palgrave Macmillan.

Gottzén, L. (2017). Monsters in the closet: The affective spaces of (not) coming out as a violent man. ACME: An International Journal for Critical Geographies, 16(3), 528-547.

Gottzén, L., \& Jonsson, R. (2012). Goda män och Andra män. In L. Gottzén \& R. Jonsson (Eds.), Andra män: Maskulinitet, normskapande och jämställdhet (pp. 7-23). Malmö, Sweden: Gleerups.

Gottzén, L. \& Sandberg, L. (2019). Creating safe atmospheres? Children's experiences of grandparents' affective and spatial responses to domestic violence. Children's Geographies, $17(5), 514-526$.

Government Offices of Sweden (2016). Fact sheet: National strategy to prevent and combat men's violence against women. Retrieved from www.government.se/informa tion-material/2016/11/fact-sheet-national-strategy-to-prevent-and-combat-mens-vio lence-against-women/

Granlund, J. (16 September 2015). 'Linneas' mamma: Det är rent förtal. Aftonbladet, p. A16.

Hall-Sanchez, A. (2016). Intimate violence against rural women: The current and future state of feminist empirical and theoretical contributions. Sociology Compass, 10(4), 272-283.

Katz, J. (1995). Reconstructing masculinity in the locker room: The Mentors in Violence Prevention project. Harvard Educational Review, 65(2), 163-175.

Marcus, G. E. (1998). Ethnography through thick and thin. Princeton, NJ: Princeton University Press.

Men for Gender Equality. (2014). MVP-manual för gymnasiet. Stockholm: Men for Gender Equality.

Sandberg, L. (2013). Backward, dumb, and violent hillbillies? Rural geographies and intersectional studies on intimate partner violence. Affilia, 28(4), 350-365.

Statens offentliga utredningar. (2016). Ett starkare skydd för den sexuella integriteten: Betänkande av 2014 års sexualbrottskommitté (SOU 2016:60). Stockholm: Wolters Kluwer.

Stenbacka, S. (2011). Othering the rural: About the construction of rural masculinities and the unspoken urban hegemonic ideal in Swedish media. Journal of Rural Studies, 27(3), 235-244.

Sundén Jelmini, M., Paulin, S., Nilsson, D., \& Baltscheffsky, S. (28 March 2010). Bjästaborna ber om att hatet ska ta slut. Svenska Dagbladet, p. A6.

Sveriges Radio. (28 March 2010). Kommunalråd reagerar starkt över att 'Bjästa' används som skällsord. SRP4 Västernorrland.

Sveriges Radio. (10 September 2015). Beata Gårdeler om Flocken och den svenska ängsligheten. SRP1 Kulturnytt. 
170 Lucas Gottzén and Anna G. Franzén

Sveriges Television. (24 March 2010). Den andra våldtäkten. SVT Uppdrag Granskning.

Swedish Language Council. (2010). Språkrådets nyordslista 2010. Retrieved from www. sprakochfolkminnen.se/sprak/nyord/nyordslistor.html

Wendt Höjer, M. (2002). Rädslans politik: Våld och sexualitet $i$ den svenska demokratin. Malmö, Sweden: Liber.

Wennstam, K. (2015). Flickan och skammen. Stockholm: Albert Bonniers förlag. 


\title{
11 Sexual transgressing \\ Situational and narrative perspectives
}

\author{
Laura Marie Schierff and Marie Bruvik Heinskou
}

\section{Introduction}

In this chapter, we investigate accounts of sexual transgressions provided by the individuals who committed them. Following the proposition of Bernasco (2011), this chapter posits that talking to individuals involved in transgressive behaviours 'is vital to knowing and understanding' the transgressions in question (p. 3). In this chapter, we use qualitative interviews with individuals who, in their own words, committed a sexual transgression but were not reported to the police. We use the term 'sexual transgression' rather than 'rape' or 'sexual offence' in this chapter because the participants in our study were not reported nor convicted for their actions.

In sociology and related disciplines, sexual transgressions have long been the subject of inquiry (Cahill, 2001). In a Danish context, research has investigated the situational characteristics of sexual transgressions and the personal characteristics of the individuals reported to the police for committing them (Balvig et al., 2009; Heinskou, 2010, 2015; Laursen et al., 2009). Additionally, large-scale victimisation surveys have provided information on the prevalence and characteristics of sexual transgressions not reported to the police (Deen et al., 2018; Heinskou et al., 2017; Helweg-Larsen, 2012; Pedersen et al., 2017). Whilst there is nothing new in interviewing individuals involved in transgressive behaviours, the field of research on sexual transgressions is characterised by a lack of knowledge on the situational characteristics of these transgressions and the explanations provided for them by the individuals committing them. Specifically, this is the case amongst the understudied population of individuals who have committed sexual transgressions but who were not reported to the police.

Historically and contemporarily, qualitative interviews with individuals committing transgressions of varying kinds have been used commonly within both sociological and criminological research (Bernasco, 2011; Copes \& Hochstetler, 2011; Katz, 1988; Presser, 2004, 2008, 2009; Presser \& Sandberg, 2015; Tonry, 2011). Consequently, the epistemological status of accounts of transgressions amongst the people committing them has been the subject of considerable scientific debate (Bernasco, 2011; Copes \& Hochstetler, 2011; 
Elffers, 2011; Maruna \& Copes, 2005; Presser \& Sandberg, 2015). In these research contributions, it has been argued that although we cannot render the accounts of transgressions amongst the people committing them 'truths', they arguably represent 'unmistakable sources of evidence' (Presser \& Sandberg, 2015, p. ix).

In the literature, the descriptions of the circumstances in accounts of sexual transgressions have been argued to serve as stigma management tools (Farmer et al., 2016) and it has been argued that engaging with the individuals whose actions we consider transgressive risk mitigating the possibilities for condemning such actions (Baumeister, 2012). In this chapter, we acknowledge that the accounts and explanations for sexual transgressions provided by the individuals committing them constitute specific self-conceptions. In this respect, we render such accounts biased and consequently emphasise that our analysis concerns the situational characteristics of sexual transgressions from the perspectives of the individuals committing them. We also contend, however, that the accounts of the situations in which the sexual transgressions were committed hold unique possibilities for contributing with knowledge on the experiential properties of sexual transgressions from an overlooked perspective.

We investigate the accounts of sexual transgressions provided by three young men who, in their own words, committed sexual transgressions but who were not reported to the police. Because of the risk of disclosure and fear of stigmatisation, the participants can be understood as a hard-to-reach population (Bonevski et al., 2014; Ireland \& Craig, 2015). The participants were recruited in the wake of a national sexual victimisation survey carried out in 2017 (Heinskou et al., 2017). Through extensive news media and social media coverage of the findings from the victimisation survey, we asked for stories of committing sexual transgressions (Heinskou, 2017). Only three individuals responded, underlining the difficulties in recruiting participants for research projects that inquire into the topic of sexual transgressions. We conducted semi-structured qualitative research interviews ranging from one and a half to two hours' duration in Danish university campus settings. All interviews were conducted, transcribed and anonymised in Danish. The excerpts presented in this chapter were translated into English. We began all interviews with a careful explanation of the aim of the research and that the intention of the inquiry was not to deem the participants or their actions right or wrong, good or bad, but to nuance the prevailing understanding of sexual transgressions. Given the sensitive nature of the topic, as well as the therapeutic resemblances of the qualitative interview, we asked questions and followed up on themes brought forward by the participants in order to not leave the participants more exposed or vulnerable than they were before the interviews. The interviews covered the following topics: general information of the participants (such as their age and nationality), the situation in which the transgression was committed, the aftermath of the sexual transgression, perspectives on the present and future, reflections on potential formal and informal punishment and reflections on Danish 
sexual culture. The interviews were conducted as semi-structured qualitative research interviews, and the participants were not interrupted if they did not reflect upon the topics in the intended sequential order. We ended all interviews by asking the participants for potential additional topics or reflections they wished to discuss.

In this chapter, we view the participants' accounts of their transgressions in a situational perspective and identify and discuss the situational characteristics of the three transgressions described. In this investigation, we identify two core characteristics upon which the participants placed emphasis: alcohol intoxication and misunderstanding signals of consent and the absence of consent. Hereafter, drawing on the narrative tradition within qualitative research, we view the accounts of the situations as epistemological resources of social significance because they combine perspectives the past, present and future (Bengtsson \& Andersen, 2017; Riessman, 2008, 2017). We combine this view with the widely used concepts for analysing explanations for transgressive behaviours from Sykes and Matza's (1957) Techniques of neutralization, Scott and Lyman's (1968) Accounts and Scully and Marolla's (1984) Vocabulary of motive. In doing so, we aim to understand the relationship between the situational characteristics, the explanations these characteristics make possible and the possibilities in these explanations for constituting specific self-conceptions amongst the participants. In the following, we begin by looking at the three accounts of sexual transgressions.

\section{Three accounts of sexual transgressions}

\section{David's transgression}

David is a man in his mid-20s who, a couple of years before the interview, had, in his own words, attempted to rape his female friend during a sleepover after a private party whilst he was under the influence of alcohol. In the interview, David described the situation as follows:

DAVID: 'Well, (...) I just had a lot of alcohol, and I had trouble distinguishing black from white, I mean - and I sensed that the other guest, she was - she was interested in me from the moment she arrived. She asked a lot about me. We talked and we talked - I don't remember what we talked about to be honest. But at some point, we all fell asleep, and I'm on the futon with her and we have sex and I just think - I mean - we were so drunk - the thing about contraception - we didn't think about that and ... - I think she was a bit like, 'Are you sure you can manage?' And I was just like, 'Yeah, yeah, let's just do it'. But I couldn't keep an erection. It wasn't - it wasn't possible, I think. But I think we had sex. And then she left to smoke a cigarette at four in the morning, and I woke up and she was just sort of gone, and then she had apparently locked herself out of the apartment and didn't want to wake up the rest of us by ringing the door bell, so. Luckily 
for her, she was dressed and could just go home. But I guess I felt a bit anxious about the fact that suddenly she was gone because I just wanted to - to have more sex or something erotic, so - then, I just see my friend who is lying naked on the floor and (...) It was quite weird because I didn't feel drunk. It was like I had a clear vision in that exact moment when I stood there in the morning and - - but it was a phase of transition, I guess. When it burns - and when the alcohol begins to set in because I couldn't remember it when I woke up again after I had slept the second time. It is like - I don't know whether you can call it an alcohol psychosis or something like delirium, which I have read about. It just felt unreal ... You feel clear headed, but you're not at all. Your blood alcohol level is 3 point something'

\section{$(\ldots)$}

INTERVIEWER: 'Yes'.

DAVID: 'When it went wrong. But then I just saw her lying there naked on a mattress on the floor next to her boyfriend and just thought, "Okay, if the other one has left, I'll have sex with this one. We've had sex before". Not that it justifies anything'.

INTERVIEWER: 'No, but it was that logic?'

DAVID: 'It was that vulgar logic one has'.

INTERVIEWER: 'Okay'.

DAVID: 'And then I lay down beside her and sort of tried to put my penis inside her, but it didn't really work because I was so drunk - so [I] sort of gave up, I think'.

David committed his transgression in his own apartment after a private party. Considering the locality of the incident, David's transgression resembles that of the most frequently occurring type of sexual transgression involving successful or attempted forced intercourse (Heinskou et al., 2017). In Denmark, most sexual transgressions are committed at private residences and happen during night time after a private party. Moreover, the majority of sexual transgressions occur between people who know each other prior to the transgression (Heinskou et al., 2017). Considering this, we can understand David's account of the transgression as a typical example of situations of sexual transgressions according to its spatial, circumstantial and relational characteristics. However, most sexual transgressions involve verbal interaction prior to the transgression between the individual committing the transgression and the individual against whom the transgression is committed (Balvig et al., 2009; Heinskou et al., 2017). David's account, however, involves no verbal contact with the woman against whom he committed his transgression, and, consequently, his account is devoid of descriptions of potential signals of consent. Besides the spatial and circumstantial characteristics, we also see how notions of emotional factors are present in David's account of the situation, as well as how alcohol intoxication is 
emphasised in his account. After presenting the accounts of the two other participants, we discuss how alcohol as a situational factor simultaneously shapes the possibilities for mitigating concepts of responsibility and identity in David's explanation of his transgression. Next, we turn to the accounts of the situations in which the two other participants, Jasper and William, committed their transgressions.

\section{Jasper's transgression}

The second participant, Jasper, is a man in his mid-20s who, in his own words, sexually transgressed against a man he had met on an online dating platform. Jasper and the man had agreed to meet in a meeting room at a public library and had exchanged messages prior to the physical encounter. The two men had discussed Jasper performing oral sex on the man, but when they entered the room in which they had agreed to meet, the man voiced concerns about the circumstances of the encounter. Jasper and the man began kissing, but then the man again hesitated. In the interview, Jasper described that the man was 'uneasy':

INTERVIEWER: 'And he verbalises concerns about the place and being discovered?' JASPER: 'Yes, at this point. That's what he says. "What if -", and then I say like, "Nothing will happen. For sure nothing will happen. There is time enough to -" - and then ... then I begin opening his pants - I mean - and begin to - I mean - begin giving him a blowjob where - I mean - it goes ... it goes very fast from that - I mean - I mean, he comes very fast ... so the duration of the blowjob might be a minute or something like that. It goes very fast'.

INTERVIEWER: 'Okay'.

JASPER: 'But to begin with, he sort of $\ldots$ he moans - and again - that doesn't mean he thinks - but he - then that's what he says - still quite uneasy er - , and then ... and then at some point, [he] begins saying like, "No, stop"'.

INTERVIEWER: 'Before he comes?'

JASPER: 'Before he comes. During that minute. Then, there's like 30 seconds or twenty seconds where he like - I mean - where he's in my mouth and where he moans and is uneasy but the last 30 seconds, he says, "No, stop" - and tries to push me away'.

INTERVIEWER: 'Pushes you away? Physically?'

JASPER: 'Yes, he pushes my shoulders - er - I mean - '

INTERVIEWER: 'Do you look at him?'

JASPER: 'Yes, I look at him, but I continue'.

INTERVIEWER: 'Do you remember what you see? Is he looking at you too?'

JASPER: 'I think he looks away actually. Err - and - and says that thing - definitely says "stop" - multiple times and also says "no" and like - pushes my shoulders - but then he comes - the way I remember it - very fast after that - and then - then I get up fast and - I mean - and yes - I think ... at 
that time, I was super horny so I might have seen things differently. So, I don't think, I think so much about it - don't think a lot about it. Not until afterwards. And probably not until he's gone. So yes, he said no. I think I closed his pants'.

INTERVIEWER: 'Yes'.

JASPER: 'And then ... he says ... that thing. I mean, I think - I don't remember it so clearly. I think it was like - yes what does he say? I think maybe I thought a lot about that thing ... that he says "stop" and "no", so I remember that clearly'.

INTERVIEWER: 'Do you remember what it feels like when he said that?'

JASPER: 'At that time, I've been ... horny and very "at it"”.

INTERVIEWER: 'Yes'.

JASPER: 'So, to be honest, I'm quite sure that I didn't think - I'm pretty sure that I didn't think so much about ... about it. Because then I wouldn't have ... fought against it, when he fought against it'. INTERVIEWER: 'Yes'.

JASPER: 'But then I stand up, and he avoids my gaze and sort of looks ... in other directions and says "okay" and that he needs to leave; I think that's what he says'.

Jasper's account of the situation involves a semi-public locality in the form of a meeting room at a public library during daytime. It involves two men. In this sense, Jasper's account contrasts the common perception of sexual transgressions as a phenomenon occurring between men and women (Heinskou et al., 2017; Laursen et al., 2009). Moreover, Jasper had contacted the man on an online platform, which means that the two were neither strangers nor well acquainted in a traditional sense. On the one hand, the two men had not met prior to the transgression, considering which we can understand the man as a stranger to Jasper prior to their encounter. On the other hand, the two men had exchanged messages prior to the encounter through an online dating platform. In this sense, the relational distance between Jasper and the man is best characterised using the definition of relational distance found in the term contact rape, which is commonly used to denote scenarios in which interaction takes place prior to the rape or, as in the present case, prior to the sexual transgression (Heinskou et al., 2017). Later in this chapter, we investigate how the interactions preluding the transgression shape the possibilities for explaining what happened and for constituting specific self-conceptions. Below, we turn to the account provided by William, who similarly described both verbal and physical interactions prior to his transgression.

\section{William's transgression}

The third participant, William, is a man in his early 30s who, in his own words, transgressed against a woman he met at a private party six years before the interview. In the interview, William described the situation as follows: 
WILLIAM: 'I mean, we had - you know - we hung out all night, and then at some point, I think we're in the kitchen and we kiss - err - it's a bit difficult to remember my exact moves - it's a bit difficult to recall. But I recall that suddenly, it's 2 AM, and at some point, the party dies out. Err - and my friend lived in a relatively large house, so there was space for us to sleep in a guest room. And we do that - her and I, and I - err - there was a single bed, and - you know, like - totally polite I say, "Hey, wouldn't you like to sleep in the bed, then I'll sleep on the floor?" And it stays like that for - like - five or ten minutes, right? - while we're talking - and then, "Ah, okay, I could also get up on the bed, right?". And then we're there making out'.

INTERVIEWER: 'And that's okay with her?'

WILLIAM: 'And, that's totally okay - and err - you know - then we begin touching each other a bit, and I remember that as being quite mutual, as well. And then at some point, I think, "Yes, then we're good to go. Let's take each other's clothes off'. Err, and at that point, I believe I can feel that she begins pulling out and says, "Ah, okay. Maybe we should slow - slow down" - I don't remember which words she used'.

INTERVIEWER: 'But she says something?'

WILLIAM: 'Yes, or she's like (William makes a sound indicating hesitation). Maybe not with those - with those exact ....'

INTERVIEWER: 'Can you see each other?'

WILLIAM: 'It's pretty dark ... And I can't recall the words or gesticulations she uses, but it's not that I think that "Ah, she's not into this". I actually think that she's in on it, and that's my impression the whole way through it - err - and we have sex, and afterwards, I think "Okay, she was" - "it was sex", but it wasn't that I thought "Wow, that was great", or that it was nice. There was something wrong, and I think I had trouble understanding it in the situation - what it was - and then when we woke up the day after, the atmosphere was "sort of gloomy". And I think at that point, I'm probably still - unable to understand why the atmosphere is gloomy. Because I thought, "Hey, that was just a fun night" - err - and it actually - doesn't take many days before I talk to my friend who threw the party - where he - err - confronts me and says, "What have you done? Because I hear that that girl - that she wasn't that happy about what happened"'.

William's account of his transgression resembles the accounts provided by both David and Jasper. As in David's account of his transgression, the spatial and circumstantial characteristics in William's account resemble the most frequently identified form of sexual transgression: one that takes place at a private residence after a private party and the person committing the transgression and the person against whom the transgression was committed being acquainted prior to the transgression (Heinskou et al., 2017). William also described that his transgression took place in a post-party context and noted that he was under 
the influence of alcohol. Contrary to David's account and similar to Jasper's, William's account involved descriptions of interactions between him and the woman against whom he committed his transgression. Subsequently, we further investigate these characteristics.

\section{Sexual transgressions and alcohol intoxication}

While criminological research has traditionally used rational choice-based models of decision-making in understanding sexually transgressive behaviour (Abbey et al., 1996; Balemba \& Beauregard, 2012; Beauregard et al., 2005; Wilson et al., 2002), the accounts of both David and William pose challenges to models founded on such assumptions. Newer criminological perspectives have argued that these challenges implicitly downplay the seductive nature of transgressions (Ferrell, 1997, 2004; Hayward, 2007, 2012; Katz, 1988), but the challenge to this assumption appears different in the present case. Both the accounts of David and William involved descriptions of alcohol intoxication, a characteristic which research has linked to sexually coercive behaviour (Demant \& Heinskou, 2011). Looking at David's account, we see that he said, 'Okay, if the other one has left, I'll have sex with this one. We've had sex before', to describe how he makes the decision to commit his transgression, which he describes as his 'vulgar logic'. In this sense, David described a decision-making process, but the persistent references to the influence of alcohol intoxication in his description introduced alcohol as the backdrop of this decision. This inference resembles the finding that an individual's propensity to use sexually coercive tactics and both verbal and physical means of force increases with the consumption of alcohol (Abbey \& Harnish, 1995). From William's account, however, such an inference resting on the assumption of conscious decision-making appears troublesome. William committed his transgression in the aftermath of a private party, but contrary to David, William described thinking that 'she's in on it, and that's my impression the whole way through it' and that it was not until the next day that he realised 'the atmosphere' was 'sort of gloomy'. This reasoning poses challenges to an understanding of alcohol intoxication facilitating decisions to use coercive tactics. Instead, it allows for an understanding of alcohol intoxication as the reason for difficulties in perceiving and responding to signals of consent and the absence of consent. As such, David's and William's transgressions thematise the role of alcohol as a situational characteristic of sexual transgressions in two distinct manners. In the following interviews with both David and William, drawing on perspectives from narrative criminology (Presser \& Sandberg, 2015) and vocabularies for analysing explanations for transgressive behaviours (Scott \& Lyman, 1968; Scully \& Marolla, 1984; Sykes \& Matza, 1957), we investigate alcohol as an explanation for the sexual transgressions as they occurred. In the interview, William described:

WILLIAM: "I think that ... firstly, I don't think it would have happened if I hadn't been drunk. But that's also - you know ... I was pretty shy at that time err - so for me, at that time, I think that maybe - also the thing about 
when alcohol was introduced, it was easier to talk to - er - the girls in the group, right? Err - but then, at the same time, more difficult to understand 'Hey, if I like you, then why don't you like me?"'

William's descriptions resemble the finding that alcohol intoxication has been found to hamper an individual's ability to perceive and respond to signals of consent and non-consent (Steele \& Josephs, 1990). William's statement contains the underlying assumption that sober-me would not have committed the transgression. Through this, William described a change of self in which his intoxicated self was contrasted to his normal self. However, in the interview, William mitigated his initial absolute statement:

WILLIAM: 'I won't use alcohol as an excuse, but - it might be an enabler in some ways, and for me, it was a lot about that thing that ... the conversation just flows easier when you're drunk, right? But - but it wasn't I mean - in that way, I don't think it would've happened, if we hadn't been drunk that day, but - but that doesn't mean it's the alcohol's fault'.

Thus, we see how William appeared conflicted over the degree of explanatory power that could be attributed to his alcohol intoxication. In this way, the explanation resembles the chaotic explanations found within the narrative analytical perspective (Bengtsson \& Andersen, 2017) in which the events and factors are linked in a non-consistent manner. In sum, we see how alcohol as an explanation in the case of William enabled social interaction: 'the conversation just flows easier when you're drunk, right?' and that, to William, it 'doesn't mean it's the alcohol's fault'. William's description can be understood as a reference to what research has termed the social grey zone, ${ }^{1}$ which arises when young people engage in alcohol consumption and sexual interactions (Demant \& Heinskou, 2011). As evident from above, the influence of alcohol was persistently noted by David in his account of the situation in which he committed his transgression. However, as we shall see, David also appeared conflicted over the influence of alcohol. Describing the situation as 'unreal', David placed heavy emphasis on the distorting qualities of his intoxication. He emphasised this by using vocabulary derived from established conceptions of intense alcohol intoxication. Through the description of a 'phase of transition' and 'when it burns - and when the alcohol begins to set in', David established the impact of alcohol, referring to its physiological qualities. In doing so, he drew on medicalised language, such as having an 'alcohol psychosis' and the description 'delirium'. David's explanation resembles findings from research amongst criminal sex offenders using medicalised language as a means to understand their own actions and, consequently, themselves (Rickard, 2015). In the interview, David described the following:

DAVID: "That was sort of the first time I realised that I had rape-like behaviour when I was very drunk. Because - because it sort of took away my - my 
guard and my filter. I mean, then it became something like - almost like almost survival. Then you just act instinctively'.

While David previously described alcohol as changing his perception of the situation, David here described a change of 'self'. David's description of acting 'instinctively' and in: of 'survival' alluded to an understanding of alcohol as causing the surfacing of his degenerated self. Though David formulated this change as a negative change, it simultaneously allowed for a sharp distinction between David's normal self and his intoxicated self.

In sum, David and William both placed emphasis on the influence of alcohol in explaining their sexual transgressions. In the case of David, alcohol was introduced as a material, yet intra-individual driver causing both distortions of the situation and himself, the backdrop of his decision to transgress. William similarly placed emphasis on his intoxication and conceptualised the influence of alcohol as causing difficulties in understanding potential signals of absence of consent. From a situational outlook, the participants' persistence in describing changes in the self or in the ability to perceive and respond to signals of consent and the absence of consent emphasises alcohol as a situational factor that can viably illuminate the complexities in sexual transgressing and the difficulties in viewing them as results of cool-headed, rational decision-making.

According to Sykes and Matza (1957), individuals who transgress the moral boundaries of society feel guilt and shame for their actions (Sykes \& Matza, 1957). As such, this theory posits that moral transgressors are conscious of the wrongfulness of their actions and defend these in accordance with the norms of the majority, as has been extensively argued in the criminological literature (Copes \& Hochstetler, 2011; Farmer et al., 2016; Maruna \& Copes, 2005; Maruna \& Mann, 2006). Here, the main assertion is that by explaining transgressive behaviours through Techniques of neutralisation, the individual does not challenge the conventional values of society. Instead, the excuse functions as a simultaneous affirmation of such values and a protection of the individual's self-conception (Sykes \& Matza, 1957). Following this, we view the explanations provided by the participants not only as descriptions of their perspectives on what happened but also as meaning-making tools of both their transgressions and themselves.

In the vocabulary of Scott and Lyman (1968), justifications are distinguished from excuses: 'Justifications are accounts in which one accepts responsibility for the act in question, but denies the pejorative quality associated with it' (Scott \& Lyman, 1968, p. 47) and 'Excuses are accounts in which one admits that the act in question is bad, wrong, or inappropriate but denies full responsibility' (Scott \& Lyman, 1968, p. 47). In this perspective, we can understand the accounts of alcohol intoxication as explanations for the sexual transgressions through which the participants do not challenge the wrongfulness of the transgressions, yet, at least partly, omit themselves from responsibility. Consequently, the explanations function as excuses rather than justifications (Scott \& Lyman, 1968; Scully \& Marolla, 1984; Sykes \& Matza, 1957). In this sense, they 
function as tools for separating the act from the individual. The participants therefore implicitly morally condemn their actions, yet maintain a sense of self that is within the moral boundaries of society.

Considering alcohol intoxication as an explanation for the sexual transgressions, the ideal typical excuse identified by Scott and Lyman (1968) within their vocabulary of Accounts, appeal to defeasibility can assist our understanding; in this concept, an individual describes not being fully informed or that his/her 'will' was not completely 'free' (Scott \& Lyman, 1968, p. 48). William described the influence of alcohol as making it 'difficult to understand', and David referred to 'instincts' and 'survival'. The explanation can therefore be argued to implicitly challenge the question of free will, as posited by Scott and Lyman (1968). As such, responsibility is, if not denied, then mitigated (Sykes \& Matza, 1957).

The descriptions of alcohol intoxication also resemble that by Scully and Marolla (1984), who developed ideal typical excuses for criminal sex offending. According to these authors, the use of alcohol and drugs is defined as an explanation for sexual transgressions caused by intoxication, which 'brought out what was already there' and that things 'rose to the surface' (Scully \& Marolla, 1984, p. 538). Recognising the cultural context of the explanation (Phoenix, 2016) and its formulation in accordance with implicit maxims (Scott \& Lyman, 1968, p. 53), we can understand the explanation as one in which alcohol is introduced as a culturally recognised explanation for changes in behaviour (Scott \& Lyman, 1968). The emphasis on alcohol intoxication therefore offers possibilities for the participants to provide accounts that partly contest their responsibility for the transgressions. Through this, we see how the accounts of circumstantial factors function as means through which specific self-conceptions can be constituted amongst individuals who have committed sexual transgressions.

Through a close reading of the experiential properties of the situations in which the sexual transgressions were committed, we see how the descriptions of the influence of alcohol intoxication pose challenges to rational choice-based models of sexually transgressive decision-making. In this sense, the accounts illuminate the complexities in scientific investigations of sexual transgressions and the need to develop new theoretical and analytical models that can account for the ambiguities, complexities and latencies associated with the phenomenon. Simultaneously, we see how such explanations can assist our understanding of how individuals who have committed sexual transgressions view the relationship between what they did and who they are. Subsequently, we look at how the participants described misunderstandings and introduced them as explanations for their transgressions.

\section{Sexual transgressions as misunderstandings}

Both Jasper and William described the situations in which they committed their transgressions as characterised by difficulties in understanding the signals sent by the individuals against whom they committed their transgressions. They both 
described that they did not realise until afterwards that what had happened had not been consensual. As we see below, the participants explained these misunderstandings through references to previous sexual experiences and commonplace depictions of what constitutes stereotypic male sexuality, as well as what constitutes a sexual transgression. In the interview, William described:

WILLIAM: 'I actually think that it wasn't until the next day that I realised that there was - there had been something where she had said or done something where I probably had - yes - basically ignored it'.

William described noticing hesitations from the woman against whom he committed a transgression, but he also stated that he thought she was 'in on it'. William described experiencing the intimate interaction as 'quite mutual', yet the next day, he sensed that 'the atmosphere was sort of gloomy'. In the literature, verbal and physical interactions are argued to cause grey zones because they blur the demarcation of consensual and non-consensual interactions and the transition between them (Hanser, 2016; Heinskou et al., 2017; Stefansen \& Smette, 2006). In a Danish context, research has demonstrated how young people hold strict definitions of what constitutes a proper rejection (Johansen, 2016). Considering this, we can view the convergence of William's description of the sound indicating potential hesitation from the woman against whom he committed his transgression and the existence of cultural standards for proper rejections as cultivating the possibility for his misunderstanding. However, it should be noted that such difficulties and grey zones have also been argued to be amongst the rape myths that make up the commonplace depictions of both non-reported sexual transgressions and criminal sex offending (Ryan, 2011). Similarly, Jasper explained his misunderstanding through descriptions of the difficulty in perceiving and responding to potential signals of the absence of consent. Jasper explained the occurrence of his misunderstanding through references to the resemblances between the situation and his previous (consensual) sexual experiences:

JASPER: 'So, I probably project my - I mean when I am in this kind of situation, I also think about what might happen ... but that's the part of it that creates a bit of excitement which ... I think is super titillating in all sorts of ways. Er - and then I think that I can recognise what situation he finds himself in. But I never know - I cannot know. So, I think that's how I interpret his - I mean - uneasiness'.

In explaining his transgression, Jasper described thinking that he could recognise consent because he was accustomed to similar experiences with casual sexual encounters in semi-public settings. In this manner, Jasper explained the misunderstanding as caused by projections of his own experiences, distorting his ability to perceive the man's hesitation as a signal of the absence of consent. In the interview, Jasper elaborated: 
JASPER: 'I think that the image I have, and most people have, of rape is that it is you know - the sort of - that it sort of is the extrovert masculine sexuality that is related to rape. I mean - and that it's easier to relate that to a sexual transgression which is like - which is ... related to violence. Because you sort of think that the extrovert masculine - you know - masculine sexuality is typically stronger. In all the porn movies of male homosexuals, the male has the lead role and is generally taller and broader and so on - so in that way, it mirrors the male-female relationship where you're also used to think that is ... the male role that's the one that can primarily rape'.

In the above, Jasper described how he perceives the 'male role that's the one that can primarily rape'. In the literature, such culturally derived perceptions of masculine sexuality have been argued to contribute to the persistent rape myths that surround commonplace depictions of sexual transgressions (Edwards et al., 2014; Hanser, 2016; Ryan, 2011; Stefansen \& Smette, 2006). Considering this, we can view Jasper's explanation of his misunderstanding leading to his transgression as a thematisation of the close relationship between cultural images and the possibilities for making sense of oneself and one's actions. The literature has established how cultural images of rape scenarios bear implications for the ability to define sexual transgressions amongst victims (Edwards et al., 2014; Stefansen \& Smette, 2006). Jasper's description suggests that this might also be the case in understanding one's own behaviours as transgressive. Moreover, we can understand Jasper's explanation as one that thematises the widely disputed relationship between the cultural images offered in the porn industry and sexually transgressive behaviour. However, while research has conceptualised this relationship as one in which exposure to pornographic images increases rape proclivity (Cahill, 2001; Wright et al., 2016), the influence of pornographic images is given a different status in Jasper's explanation. Rather than explaining his transgression as resulting from perceptions of the legitimacy of using coercive tactics in the pursuit of obtaining sexual interactions, Jasper described how these images hampered his ability to perceive both himself as the transgressor and the signals of the absence of consent. Consequently, Jasper's explanation illustrates not only how cultural images and the possibilities for making sense of transgressive behaviours are interwoven but also how these cultural images permeate the very situations in which determining signals of consent and signals of the absence of consent is vital.

As in the case of alcohol intoxication as an explanation for sexual transgressions, the combination of the perspectives of Sykes and Matza (1957), Scott and Lyman (1968) and Scully and Marolla (1984) allows for an understanding of the explanation as simultaneously constituting specific self-conceptions amongst the participants. Explaining the sexual transgressions as resulting from misunderstandings caused by inabilities to distinguish signals of consent from signals of absence of consent does not challenge the wrongfulness of the transgression. Yet, it at least partly omits both William and Jasper from responsibility (Scott \& Lyman, 1968; Scully \& Marolla, 1984; Sykes \& Matza, 1957). In 
the terminology of Scott and Lyman (1968), we can view this explanation as an appeal to accident, through which the transgression is explained as nonintentional (p. 47f). Through this explanation, the participants explain their actions, yet retain what Scully and Marolla (1984) refer to as nice guy images (p. 537ff). In this respect, especially Jasper's statement that his perspective on the stereotypical images of sexual transgressions causing his misunderstanding is what 'most people have' illustrates the relationship between the explanation and the cultural context in which it is embedded. Through this, the transgression is not just explained as an 'accident' (Scott \& Lyman, 1968, p. 48) but as an accident that could have happened to anyone. It can be asserted that the recent enhanced attentiveness to grey zone characterisations of sexual transgressions, which are brought about by, for example, the \#MeToo movement, has simultaneously constituted a vocabulary of recognisable excuses for transgressive behaviours. The same enhanced attentiveness, however, can be argued to have constituted such misunderstandings as less culturally recognised legitimate explanations for sexual transgressions.

As in the case of alcohol intoxication, explaining sexual transgressions as resulting from misunderstandings allows for a contestation of responsibility amongst the participants and thus thematises how accounts of circumstantial factors allow for the constitution of specific self-conceptions. Explaining sexual transgressions as resulting from misunderstandings draws attention to the difficulties in strictly demarcating consent from non-consent and thematises how the perception of consent may vary across individuals, time and context.

\section{Concluding remarks}

None of the participants in our study were reported to the police, but all three participants described their actions as sexual transgressions. First, this can be argued to strengthen the participants' possibilities for defining what happened in the situations in which they committed their transgressions. Second, it means that the veracity of their accounts cannot be investigated through comparisons with, for instance, police reports through data triangulation (Lindegaard, 2011). Considering the situational characteristics described by the participants, an analysis based on interviews with the individuals against whom the transgressions were committed would likely produce other, and potentially, conflicting findings than the ones presented. Such findings obtained through 'actor triangulation' (Lindegaard, 2011, p. 117f) could be relevant to the understanding of the interactional dynamics of sexual transgressions in a situational perspective.

It can be argued that analysing alcohol intoxication and misunderstandings of signals of consent and the absence of consent as situational characteristics of sexual transgressions, as well as giving voice to the individuals committing sexual transgressions rather than the individuals against whom these actions are committed, is an unethical venture (see Baumeister, 2012). In this sense, this chapter can be accused of contributing to the substantiation 'rape myths' or 
'rape-supportive beliefs' (Ryan, 2011, p. 777). However, it is not the aim of this chapter to discuss the pathology or normality of the explanations provided by the participants (Maruna \& Mann, 2006). Rather, our findings suggest that research on sexual transgressions could possibly generate information on both the situational and experiential characteristics of sexual transgressing and of the self-constitutive functions of providing these accounts.

\section{Note}

1 Our use of the term 'grey zone' does not signify a downplaying of the severity of the act inflicted. Rather, our usage emphasises the described difficulties in perceiving and responding to signals of consent and the absence of consent.

\section{References}

Abbey, A., \& Harnish, R. (1995). Perception of sexual intent: The role of gender, alcohol consumption, and rape supportive attitudes. Sex Roles, 32(5), 297-313.

Abbey, A., L. T. Ross, D. McDuffie, \& McAuslan P. (1996). Alcohol and Dating Risk Factors for Sexual Assault Among College Women. Psychology of Women Quarterly, 20(1), 147-169.

Balemba, S., \& Beauregard E. (2012). Reactions to Resistance: The Role of Contextual Factorsin Sex Offending. Violence and Victims, 27(2), 148-165.

Balvig, F., Laursen, B., Sten Madsen, K., Martinussen, M. E., \& Sidenius, K. (2009). Voldtoegt, der anmeldes... Del V: Kvinder der anmeldte voldtcogt eller forsøg på voldtcegt (Reported rapes... Part 5: Women who reported rapes or attempted rapes). København: Det Kriminalpræventive Råd.

Baumeister, R. F. (2012). Human evil: The myth of pure evil and the true causes of violence. In M. E. Mikulincer \& P. R. Shaver (Eds.), The social psychology of morality: Exploring the causes of good and evil (pp. 367-380). Washington, DC: American Psychological Association.

Beauregard, E., Proulx, J., \& Rossmo, D. (2005). Spatial patterns of sex offenders: Theoretical, empirical, and practical issues. Aggression and Violent Behavior, 10(5), 579-603.

Bengtsson, T. T., \& Andersen, D. (2017). Narrativ analyse - tematisk, strukturel og performative (Narrative analysis - thematic, structural, and performative). In M. Järvinen \& N. Mik-Meyer (Eds.), Kvalitativ analyse - syv traditioner(Qualitative analysis - seven traditions) (pp. 273-294). København: Hans Reitzels Forlag.

Bernasco, W. (2011). Learning about crime from criminals: Editor's introduction. In W. Bernasco (Ed.), Offenders on offending: Learning about crime from criminals (pp. 3-12). New York: Routledge.

Bonevski, B., Randell, M., Paul, C., Chapman, K., Twyman, L. Bryant, J., ... Hughes, C. (2014).Reaching the hard-to-reach: A systematic review of strategies for improving health and medical research with socially disadvantaged groups. BMC Medical Research Methodology, 14(1), 42.

Cahill, A. J. (2001). Rethinking rape. New York: Cornell University Press.

Copes, H., \& Hochstetler, A. (2011). Interviewing the incarcerated: Pitfalls and promises. In W. Bernasco (Ed.), Offenders on offending. Learning about crime from criminals (pp. 49-67). New York: Routledge. 
Deen, L., Johansen, K. B. H., Møller, S. P., \& Laursen, B. (2018). Vold og seksuelle krcenkelser. En afdcekning af omfang og udvikling af fysisk vold og seksuelle overgreb og omfang af seksuelle krcenkelser samt en analyse af erfaringer med digitale seksuelle kraenkelser. (Violence and sexual transgression. An analysis of prevalence of physical violence and sexual transgressions and an analysis of experiences with digital sexual transgressions). København: Statens Institut For Folkesundhed.

Demant, J., \& Heinskou, M. (2011). Taking a chance: Sex, alcohol and acquaintance rape. Young, 19(4), 397-415.

Edwards, S., Bradshaw, K. A., \& Hinsz, V. B. (2014). Denying rape but endorsing forceful intercourse: Exploring differences among responders. Violence and Gender, 1(4), 188-193.

Elffers, H. (2011). Misinformation, misunderstanding and misleading as validity threats to offenders' accounts of offending. In W. Bernasco (Ed.), Offenders on offending. Learning about crime from criminals (pp. 13-22). New York: Routledge.

Farmer, M., McAlinden, A., \& Maruna, S. (2016). Sex offending and situational motivation. Findings from a qualitative analysis of desistance from sexual Offending. International Journal of Offender Therapy and Comparative Criminology, 60(15), 17561775.

Ferrell, J. (1997). Criminological verstehen: Inside the immediacy of crime. Justice Quarterly, 14(1), 3-24.

Ferrell, J. (2004). Boredom, crime and criminology. Theoretical Criminology, 8(3), 287-302.

Hanser, R. (2016). Sexual assault definitions. In F. P. Reddington \& B. W. Kreisel (Eds.), Sexual Assault - The Victims, the Perpetrators, and the Criminal Justice System (pp. 29-55). Durham, NC: Carolina Academic Press.

Hayward, K. J. (2007). Situational crime prevention and its discontents: Rational choice theory versus the 'culture of now'. Social Policy and Administration, 41(3), 232-250.

Hayward, K. J. (2012). A response to Farrell. Social Policy and Administration, 46(1), 21-34.

Heinskou, M. B. (2010). En kompleks affare - anmeldte voldtcegter i Danmark, ph.d.afhandling. (A complex matter - reported rapes in Denmark). København: Sociologisk Institut, Københavns Universitet.

Heinskou, M. B. (2015). Sexuality in transit-gender gaming and spaces of sexuality in late modernity. Sexualities, 18(7), 885-899.

Heinskou, M. B. (2017, February 18). Under sit arbejde med seksuelle overgreb, modtog sociologen et brev fra en af de stemmer, vi sjældent hører - krænkerens. Information, Moderne Tider (During her work on sexual transgressions, the sociologist received a letter from one of the individuals rarely heard - the voice of the transgressor).

Heinskou, M. B., Schierff, L. M., Ejbye-Ernst, P., Friis, C. B., \& Liebst, L. S. (2017). Seksuelle kroenkelser. Omfang og karakter. København: Det Kriminalpræventive Råd. (Sexual transgressions. Prevalence and characteristics).

Helweg-Larsen, K. (2012). Vold i noere relationer: omfang, karakter, udvikling og indsats i Danmark (Violence in intimate relations: prevalence, characteristics, trends, and intervention in Denmark). København: Statens Institut for Folkesundhed \& Syddansk Universitet.

Ireland, C. A., \& Craig, L. A. (2015). Adult sexual offender assessment. In D. P. Boer, R. Eher, L. A. Craig, M. H. Miner, \& F. Pfäfflin (Eds.), International perspectives on the assessment and treatment of sexual offenders: Theory, practice and research (pp. 13-34). Oxford: John Wiley \& Sons. 
Johansen, K. B. H. (2016). Seksuel Vold - Opfattelser og holdninger til strafbarhed og anmeldelse blandt unge (Sexual violence - conceptions and opinions on legal responsibility and reporting among young people). København: Statens Institut for Folkesundhed \& Syddansk Universitet.

Katz, J. (1988). Seductions of crime. New York: Basic Book.

Laursen, B., Balvig, F., Madsen, K. S., Martinussen, M. B. E., \& Sidenius, K. (2009). Voldtoegt der anmeldes ... Del IV: Mondene (Reported rapes ... Part 4: The men). København: Det Kriminalpræventive Råd.

Lindegaard, M. R. (2011). Method, actor and context triangulations: Knowing what happened during criminal events and the motivations for getting involved. In W. Bernasco (Ed.), Offenders on offending. Learning about crime from criminals (pp. 109-129). New York: Routledge.

Maruna, S., \& Copes, H. (2005). What have we learned from five decades of neutralization research?. Crime and Justice, 32, 221-320.

Maruna, S., \& Mann, R. E. (2006). A fundamental attribution error? Rethinking cognitive distortions. Legal and Criminological Psychology, 11(2), 155-177.

Pedersen, A., Boesen, J., Kyvsgaard, B., \& Balvig, F. (2017). Udsathed for vold og andre former for kriminalitet - Offerundersøgelserne 2005-2016 (Victimisation of violence and other forms of crime - the victimisation surveys 2005-2016). København: Justitsministeriet/Det Kriminalpræventive Råd/Rigspolitiet/Københavns Universitet.

Phoenix, A. (2016). Narrativ praksis og identitetskonstruktioner (Narrative practice and identity constructions). In I. G. Bo, A. Christensen, \& T. L. Thomsen (Eds.), Narrativ forskning. Tilgange og metoder (Narrative research. Approaches and methods) (pp. 5780). København: Hans Reitzels Forlag.

Presser, L. (2004). Violent offenders, moral selves: Constructing identities and accounts in the research interview. Social Problems, 51(1), 82-101.

Presser, L. (2008). Been a heavy life: Stories of violent men. Chicago, IL: University of Illinois Press.

Presser, L. (2009). The narratives of offenders. Theoretical Criminology, 13(2), 177-200.

Presser, L., \& Sandberg, S. (Eds.) (2015). Narrative criminology: Understanding stories of crime. New York: NYU Press.

Rickard, D. (2015). Masculinity and medicalization: Gender and vocabularies of motive in the narrative of a sex offender. Feminism \& Psychology, 25(2), 199-218.

Riessman, C. K. (2008). Narrative methods for the human sciences. Thousand Oaks, CA: Sage.

Riessman, C. K. (2017). Narrativ analyse i samfundsvidenskaberne (Narrative analysis in the social sciences). In M. Järvinen \& N. Mik-Meyer (Eds.), Kvalitativ analyse - syv traditioner (Qualitative analysis - seven traditions) (pp. 235-272). København: Hans Reitzels Forlag.

Ryan, K. M. (2011). The relationship between rape myths and sexual scripts: The social construction of rape. Sex Roles, 65(11-12), 774-782.

Scott, M. B., \& Lyman, S. M. (1968). Accounts. American Sociological Review, 33(1), 46-62.

Scully, D., \& Marolla, J. (1984). Convicted rapists' vocabulary of motive: Excuses and justifications. Social Problems, 31(5), 530-544.

Steele, C. M., \& Josephs, R. A. (1990). Alcohol myopia: Its prized and dangerous effects. American Psychologist, 45(8), 921-933.

Stefansen, K., \& Smette, I. (2006). Det var ikke en voldtekt, mer et overgrep. Kvinners fortolkninger av seksuelle overgrepserfaringer. (It wasn't rape, more like forced sex » 
188 Laura Marie Schierff and Marie Bruvik Heinskou

Women's interpretations of sexual assault). Tidsskrift for Samfunnsforskning, 47(1), $33-56$.

Sykes, G. M., \& Matza, D. (1957). Techniques of neutralization: A theory of delinquency. American Sociological Review, 22(6), 664-670.

Tonry, M. (2011). Foreword. In W. Bernasco (Ed.), Offenders on offending. Learning about crime from criminals. New York: Routledge, xvii-xxi.

Wright, P., Tokunaga, R., \& Kraus, A. (2016). A meta-analysis of pornography consumption and actual acts of sexual aggression in general population studies. Journal of Communication, 66(1), 183-205. 


\title{
12 Rape in the age of the Internet
}

\author{
Elisabeth Fransson, Trond Martinsen and Elisabeth \\ Staksrud
}

\section{Introduction}

'We who are young today have the whole world in our pockets. The prosecutor didn't understand this. There's something about the words people use, such as "child pornography" and "rape". Perhaps the law lacks words to describe reality. The new reality. This may be a reality that you, who are a bit older, don't understand. There's a new way of communicating. There are other rules'.

- Alex, a young man sentenced to prison for digital rape

A few years ago, Alex, a young Norwegian male, was sentenced to prison for more than one hundred counts of rape. One of these rapes occurred while he was eating dinner with his family. He was accused according to $\$ 192$ of the general civil penal code of 1902, which defines rape as, 'through violence or threatening behaviour, making someone have sexual intercourse with someone else, or to perform acts that correspond to sexual intercourse with oneself'. 1,2

Rape is commonly understood as involving physical, synchronous contact between two or more people: victims and perpetrators. But with the introduction of the Internet in general, and especially social media through the use of direct communication services, several possibilities have emerged for using this technology for rape remotely, either synchronously or asynchronously. At the same time, understanding these crimes has proved challenging, whether in court, in law, or in the development of legislation. While international studies of online sexual crimes have been conducted (e.g. Handyside \& Ringrose, 2017; Henry \& Powell, 2015; Renfrow \& Rollo, 2014; Klettke, Hallford \& Mellor, 2014), researchers have paid little attention to the perpetrators and their stories. In this chapter, we help to fill this gap by analysing the case of Alex, a young man sentenced to several years in a high-security prison after committing a large number of rapes online. We seek to explore how Internet-mediated rape is understood, both by perpetrators and by the court. This understanding includes, but is not limited to, the intrinsic paradox of digital rape: that people can be found guilty of raping someone they have never met, and who may be at 
a location far away. We draw on interviews with Alex and use his story, perspectives and reflections as a starting point. Our hope is to uncover some of the rationales, motivations and complexities that digital technologies have added to sexual abuse and rape situations.

Our analysis is conducted against the theoretical background of computermediated communication (CMC). We discuss how both group and individual interactions differ between face-to-face (F2F) meetings and CMC, and how this situation can contribute to our understanding of digital rape and related sexual crimes. By choosing this theoretical approach, we seek to increase the understanding of rape as a contemporary, mediated phenomenon that transcends spatial and temporal boundaries.

\section{Background: Internet-related sexual crimes}

A large body of international research has contributed to the understanding of Internet-related sexual crimes against children and youths, including the socalled grooming (e.g. Choo, 2009; Finkelhor, Mitchell \& Wolak, 2000; Gottschalk, 2011; Kierkegaard, 2008; Peter, Valkenburg \& Schouten, 2006; Staksrud, 2013; Taylor, 2011; Wolak, Finkelhor, Mitchell \& Ybarra, 2008). Research on sexting - sending or receiving sexually suggestive texts or images via mobile phones and messenger services - has also contributed to a wider understanding of the differences between wanted and unwanted sexual contact and content (e.g. Badenhorst, 2011; Drouin, Ross \& Tobin, 2015; Klettke et al., 2014; Mascheroni, Vincent \& Jimenez, 2015; Van Ouytsel, Walrave, Ponnet \& Heirman, 2015; Wolak, Finkelhor \& Mitchell, 2012). What remains less known is how young people use techniques of persuasion, deception and threats towards children and youths online, as well as young perpetrators' own perspectives on their conduct.

The way in which society views sexual offences in general, and specifically those committed via the Internet, is influenced by the media and how politicians, the police and court systems respond to these crimes. Various national legal systems around the globe are now struggling to establish legislative systems and policy provisions that will ensure universal access to the Internet, manage the international and borderless character of online information and communication, and protect and safeguard users. One of the few areas where international legislative efforts have been motivated and acted upon is the protection of children from online sexual abuse. Relevant key legal international instruments include the UN Convention on the Rights of the Child (CRC) (United Nations, 1989); the CRC's Optional Protocol on the Sale of Children, Child Prostitution and Child Pornography; and the Council of Europe's Convention on Cybercrime (Council of Europe, 2001). These instruments, and other examples, represent a moral and political consensus to protect children from abusive adult practices, including those pursued online.

But previous studies have also argued that these systems, especially national legislation, fall short of understanding and differentiating between various 
online sexual practices. A gap exists in legislation to protect against images of child sexual abuse (i.e. child pornography) and consensual sexual practices, including the sharing of sexual images, between teens (Bulger, Burton, O'Neill \& Staksrud, 2017). For instance, in the US case of A. H. v. the State of Florida (2007), a 16-year-old girl and her 17-year-old boyfriend were charged as juveniles under child pornography laws and sentenced to probation for taking photos of themselves engaging in sexual behaviour and then sharing these images with each other only. Thus,

... despite over a decade of policies related to online child protection, issues of fragmentation, unevenness in implementation and penalties intended for adults applied to minors indicate that the complex nature of the Internet and children's use of it require better informed and holistic approaches to policy and provision.

(Bulger et al., 2017, p. 758)

Underlying this concern is an understanding that online sexual engagement, exploration and even violations among youths are perhaps regrettable, yet very common, practices. For instance, a 2018 study with a representative sample of Norwegian children and youths (age 11-17 years) found that 30\% had received sexual messages (sexting) in the previous year, including half $(49 \%)$ of the 15-17-year olds. When asked about how they felt after receiving sexual messages, 35\% expressed that they felt happy, $41 \%$ did not feel anything in particular (neither happy nor upset) and 14\% were a bit upset; 11\% (mostly girls) said they were very upset (Staksrud \& Ólafsson, 2019).

These findings mean that, to many teens today, the use of Internet content and contact is acceptable for gaining information about and engaging in sexual activities. While there is of course a substantial difference between these often pubescent explorative and exploitative engagements and illegal activities (such as rape and child pornography), such situations do not provide a contextual backdrop to the case we will analyse in this chapter, which is that online sexual engagement among young people is quite common (albeit sometimes illegal) and can result from deception and pressure. When the sexual encounter happens online via the written word or still or moving pictures, the question becomes this: What difference does the technological mediation make? A better-informed and more holistic approach, as Bulger et al. (2017) have called for, needs to include the perspective and stories of perpetrators.

\section{Computer-mediated communication}

Research into $\mathrm{CMC}$ has enabled theorisation into how individual and group interactions differ between F2F and computer-mediated meetings (Kiesler, Siegel \& McGuire, 1984; Siegel, Dubrovsky, Kiesler \& McGuire, 1986). The differences that CMC makes may be summarised briefly as a reduction in social-context information and shared norms of how to communicate (Kiesler 
et al., 1984). These factors may include asynchronous communication, reduced social cues, time- and information-processing pressures, the absence of regulating feedback, dramaturgical weaknesses, a general lack of status and positional cues, social anonymity, varying computing norms and immature senses of etiquette (Staksrud, Ólafsson \& Livingstone, 2013). Another relevant factor is what Walther (1996) describes as hyper-personal communication: a more intimate and desirable communication than one would be able to establish face-toface, combined with anonymity (or even deceit) in online interactions. Such hyper-personal communication is often seen to enhance intimacy in the exchange of information, combined with feelings of close group unity. These factors can produce deindividuation, or 'a weakened ability for an individual to regulate his or her own behavior, reduced ability to engage in rational, longterm planning, and a tendency to react to immediate cues based largely on his or her current emotional state' (McKenna \& Bargh, 2000, p. 61).

Thus, when compared to F2F interaction, anonymity in online interactions is linked to both positive and creative forms of self-expression (e.g. Back, Schmukle \& Egloff, 2008; Derks, Bos \& von Grumbkow, 2008) and to increased testing and displays of non-conforming behaviour and verbal aggression (e.g. Parks \& Floyd, 1996; Ybarra, Espelage \& Mitchell, 2007). Such non-conforming aggressive behaviour can also be sexual, including sexual violence and rape, as is the situation in the case that provides the empirical basis for this chapter.

\section{Digital rape studied through one case}

\section{Methodological approach}

The empirical material we have used in this case study is drawn from an ethnographic prison study on young men in prison (see Martinsen, 2016). ${ }^{3}$ The study included 25 young men between the ages of 18 and 23 who, over a period of three months, had been in custody in a high-security prison in Norway. One of these young men, Alex, was later sentenced to prison for multiple digital rapes. The project was extended for the purposes of this chapter and was focussed only on Alex's case. Three types of empirical material pertinent to his case inform the analysis: (1) interviews with Alex, (2) Alex's diary and (3) court judgements related to his case.

We have had 15 conversations with Alex over a period of three years. ${ }^{4}$ The interviews took place while Alex was in custody, both during the court trial and after his conviction. They were open conversations (Widerberg, 2001) that usually lasted an hour and a half. Notes were taken and checked with Alex during the interviews. After each interview, the field notes were written out in full. Alex has read some of the written transcripts of the interviews. He has also been consulted on earlier drafts of this chapter; this consultation has allowed him to correct any mistakes and to provide feedback and complementary information. He has also read the latest version of the chapter. 
Alex started to write his diary when he was taken into custody. The diary has been used as background information and has provided the co-authors with contextual knowledge. Direct quotes from the diary are not provided in this article. The court judgements, which consist of the sentences related to Alex's case, were provided by Alex himself and were also downloaded from domstol.no, with the permission of the Norwegian Ministry of Justice and Public Security. The interview quotes and judgement extracts in this chapter have been translated and were later edited for maximum clarity in English.

While this chapter is based, to a substantial extent, on Alex's own accounts (as presented in the interviews), combined with the official court judgements, it is not possible to understand these accounts as direct representations of reality (Game, 1991). Alex's accounts, the court judgements and the diary must be analysed as texts produced within a specific culture in relation to a specific law at a certain moment - and from Alex's specific subject position. Thus, the work is in part inspired by a narrative tradition within criminology that focusses on how we construct stories to understand and explain our actions, who we are and our subject position (Sandberg, 2013). We have analysed the interviews, the court judgements, the diary and the texts as culturally embedded texts in an attempt to understand the logic of online sexual activity, and how Alex himself and the courts have made sense of his actions.

\section{Ethical considerations}

As researchers in the social sciences, we adhere to Norwegian national guidelines for research ethics in the social sciences, humanities, law and theology, as described by Norway's national ethics committees (see www.etikkom.no). The use of Alex as the only case demands that we as researchers follow the national guidelines for research ethics on free and informed consent and confidentiality, and that we ensure that the relationship between the researcher and the research subject will be built on human dignity and privacy, as stated in the guidelines.

Before we conducted the analysis, we ${ }^{5}$ applied to the Norwegian Centre for Research Data (NSD, from Norsk senter for forskningsdata) to extend the research project. The change involved inviting one of the already-participating informants, Alex, becoming a key informant in the chapter. NSD approved the extension, provided that new informed consent would be secured from the informant. An informed consent requires that informants understand what they are asked to participate in, what types of issues and questions they will be asked, and the potential consequences of their participation, including questions of anonymity. The consent must also be given freely, and in an informed and explicit manner.

In Alex's case, the extended part of the research represented a new topic. We provided Alex with explicit information about the intention of the work described in this chapter, and specifically how we wanted to work with his particular case. We informed Alex that we wanted to use his story as the only 
narrative in an article, and that the second co-author would continue to interview him, with a focus on the digital rapes he had been convicted of. He was also informed that the first co-author would read and analyse the transcripts from the interviews together with the second co-author. Alex was later informed when the third co-author was invited to join the research project, and he accepted the new authorship situation.

In order to be ethically sound, consent must also be given freely, which means that the consent must be obtained without external pressure or constraints on one's individual freedom. What constitutes freely given consent in Alex's particular case is found in the extension of the former research project. To participate in the extended project, Alex had to provide new and informed consent. Alex gave his consent with the understanding that only the second co-author would be in contact with him. To allow for the correction of any mistakes and for Alex to further understand the type of research we were conducting, he was given the opportunity to read earlier drafts of this article, in particular the written representations of his story. The ethical consideration of this scenario was that Alex thus became a research subject more than an object of research. On several occasions, Alex has been informed that if he changes his mind, he may withdraw his consent at any time, without suffering any negative consequences.

As researchers, we have done what we can to secure anonymity by excluding a great deal of information and by anonymising the names of prisons, places and court levels. Alex cannot be guaranteed full anonymity, however. ${ }^{6} \mathrm{He}$ understands that he might be identifiable.

Another ethical concern we have considered in the development of this project is researchers' responsibility to include marginal voices in their research. According to Norway's national ethical guidelines for research (Hvinden et al., 2016), we as researchers have a special responsibility to respect the interests of vulnerable and marginalised groups throughout the entire research process. As a prisoner and perpetrator, Alex by definition belongs to a stigmatised group. It is important for prisoners to be able to tell their stories, and it is equally important for researchers to inject newly acquired information into the existing body of knowledge. In our case, we must ask critical questions related to CMC in order to inform our understanding of digital rape and other Internet-related sexual crimes by relevant stakeholders, such as the courts.

In the context of research projects, being ethical means to be aware of what happens on the way during a given project or task (Deleuze \& Guattari, 1987), and every research position implies ethical questions and considerations. The particular ethical dilemmas in this research, from our point of view, has been Alex's position as a prisoner. Being closed up in a prison with little contact with the outside world, prisoners such as Alex often welcome researchers because they provide a break, represent the outside world and allow the possibility to talk openly. The substantial and long-term contact between the second co-author and Alex, including access to his personal diary and his court judgements, could mean that the relationship may have taken on a more 'therapeutic' or 'friend-based' nature that would then make it difficult for Alex to withdraw 
from the project. We have discussed this possibility openly and explicitly with Alex, who has assured us several times of his wish to participate. We are aware that this chapter poses an ethical dilemma related to anonymity, but as long as Alex continues to provide his free and informed consent, we will choose to publish the chapter.

\begin{abstract}
Alex's story
Alex was under 18 when he started to, as described in the verdict, 'abuse others' (Court judgement). Several of the victims were his own age. The abuses went on for several years. After a while, some of the victims reported him to the police, and a year later, he was arrested for rape. The interviews with Alex and the information from Alex's court judgements display how a typical procedure for this activity took place. First, he created different profiles by posing as a girl on different social media platforms, such as Kik, Snapchat, Instagram, Facebook and Skype, among others. In the following dialogue, Alex describes the process:
\end{abstract}

\title{
INTERVIEWER: How did you first get started with the threats?
}

ALEX: The first guy I got in touch with had a girlfriend. In court, he denied ever sending anything to my faked profile. I threatened to send a picture to her. That was the first threat; I was 16 at the time. I created my first profile when I was 15 . The threats started with disagreements, then escalated from there. The disagreements ended, and new contacts were established.

The court judgement refers, in a similar way, to how Alex initially contacted other youths and how the contact changed:

... he then contacted random boys he found on different social media, and, pretending to be a girl, he established contact. Fairly quickly, he and the individual boys started having sexualised conversations online, and pictures were exchanged, including nude photographs and pictures and films depicting sexual acts. The defendant sent pictures of girls he had found online, and, in return, the individual boys sent nude photographs of themselves.

(Court judgement)

The court understood the initial contact as 'quite innocent' and 'normal', but it quickly turned into 'sexualised talk' and the exchange of pictures before developing into threats and pressure to send more photos/film and then perform acts on Skype (Court judgement).

The court noted the pace of the online communication as one factor to consider; another factor was how Alex as the perpetrator had given orders via the Internet to the victims, combined with threats. Alex explained that these orders would also typically include demands to send pictures and/or videos depicting masturbation. Similarly, he asked for live-action masturbation, such as by forcing the victim, through threats of public exposure, to masturbate or 'put on 
a show' in front of him via a camera on Skype. Sometimes such shows included having to follow the perpetrator's continuous written and detailed instructions as to what actions, positions, angles and attire were required and, in some cases, the use of physical objects. For most of the victims, the rapes continued for a long time, as detailed in the court judgements:

Among other things, the victims have been forced to perform degrading sexual acts live on camera, in part by being recorded and watched by [name redacted], who was unknown to them, and by sending sexualised photographs without being in control of what the offender would do with the videos and pictures. Most of the victims endured repeated acts of abuse over a long period: up to a year and a half in some cases. Further, the presentation of evidence has shown that some of the acts lasted for a long time: upwards of an hour and a half. The convicted person ... demanded that the victims make themselves available whenever he wanted them to, including at night.

(Court judgement)

Through the court judgements, we can read how the victims were affected by this behaviour:

[Name redacted] stated that he was gloomy during this period. He found it difficult to go to school and was absent a lot, as he was afraid something might have been published or that his friends might find out about what had happened. As a result, he received a poor grade in conduct and orderliness, and his homework, assignments, and tests were affected. ... There is no doubt that the victims have perceived the defendant's threatening behaviour as frightening and upsetting. Where a rape is committed face to face, the victim has the possibility to react to the attack. In this case, the defendant has appeared as a hidden offender who keeps returning. The victims did not know whether the risk of new acts of abuse was over. The defendant has been an unknown offender; the victims did not know who he was, where he was, or when he might contact them again. They have been living in fear that photographs and films might be published and have had no control over whether new acts with similar threats might be posed again.

(Court judgement)

The court judgement in Alex's case indicates that the court viewed this type of rape, where the victim is coerced by threatening behaviour into performing sexual acts on themselves, as being equal to other instances of rape; in other words, offenders need not be physically present with their victims when the latter perform sexual acts on themselves; there only has to be a causal link between the threatening behaviour and the sexual acts the victims perform on themselves. The Court of Appeal later upheld the sentence, confirming the original court's assessment of the case. 


\section{Becoming a sexual person}

Alex himself has explained his role as an online sexual abuser in the context of becoming a sexual person. For him, his homosexual identity explains this development:

ALEX: I was desperate for contact but didn't know how to [go about it]. I created a profile on an online site for gay men. The site had an 18-plus age limit, but I changed my age back to 15 once I was on the site. I got a lot of responses and chose the youngest one, but he was still much older than me. I went to meet him, and we went to his flat. We watched a film and had sex. He had to tell me what to do, since I hadn't done that before.

INTERVIEWER: Did you feel used?

ALEX: I can't answer that. I felt that I got what I wanted, but at the same time I felt that it wasn't right. But, I felt as if I had to hurry. Something had to happen! INTERVIEWER: So, then you started to fake profiles?

ALEX: Yes, the online site became a textbook for how I could present myself on my profiles. And [the site] became a way of getting in touch with people the same age. (Alex, in interview)

Alex was 15 years and under the age of sexual consent (which is 16 in Norway) when he created his first profile on the online site. He went on to create additional online profiles with different representations of himself. The rationale was, as he says, 'about sexuality'. For Alex, this rationale provides the full explanation of why things happened as they did:

ALEX: I didn't have the one thing I wanted the most. If I'd been a straight 15 -yearold, none of this would've happened. I was young, curious, and ignorant and didn't understand consequences. I don't define myself as a criminal. I have, however, done criminal acts. ... I didn't know what I liked. The web became somewhere I could explore sexuality; [the victims] did that as well. The web becomes a place where you don't have to make a fool of yourself. And everyone's faking. (Alex, in interview)

The online sexual engagement, exploration and offences that Alex became involved with became for him a way to become a sexual person. Like many other youths, he used the Internet as a tool to both gain information about and to engage in sexual activities. One of the key features of online communication is the absence of social cues, which leads to potential deindividuation, where people have difficulty regulating their own behaviour and instead react to immediate cues based on their current emotional state, such as sexual arousal or excitement:

INTERVIEWER: To what extent do you perceive the people you meet online as individuals? 
ALEX: They are individuals, but not unique individuals. They don't really stand out from each other; they're just a bunch of people. There's distance - in both directions. Who initiates the conversation is irrelevant; $90 \%$ want nudes. You don't really get to know each other; you're just curious ...

INTERVIEWER: But what makes you send photos to strangers?

ALEX: It's thrilling with a stranger. You'll never see him again yet are exposed to nudity. It's a trigger. Snapchat was a breakthrough; it's what started this trend. And anyone can respond to it. (Alex, in interview)

Alex's explanation helps to show how, for him, the social context becomes reduced. Everything comes down to one issue: sexual activity on an Internet scene. There is no flirtation, no time to get to know each other, no curiosity about who the other person is; the other person's thoughts, feelings and dreams are irrelevant. Alex perceives the rules as being different from those of the offline world:

INTERVIEWER: Are there different rules for interactions online?

ALEX: There are different rules. You don't flash your dick in the physical world. You don't do that on the street. In the real world there's etiquette. The worst that can happen online is that you get blocked. That goes for how you write, as well. It's insanely upfront. You become less and less polite towards strangers. You get used to interacting with strangers. Everything that happens out there [in the offline world] can be multiplied by ten online. Of course, there's chaos when you stick all sorts of people on one platform - healthy or ill, anything. Chatting for a day or two was enough. You should be well into the online world. It's a lot about excitement.

INTERVIEWER: What do you get in return?

ALEX: It progresses from one piece of clothing to another, really. You take step after step and keep going further. Pushing limits. It gradually becomes less of a big deal. The worst that could happen is that you get a no or get deleted. (Alex, in interview)

As described in CMC theory, the different rules that are acceptable online may not reflect those in the offline world. Any vulnerability or differences associated with class and other social aspects are filtered or absent when transmitted through CMC. These differences may be greater when the recipients are vulnerable children and youths. As described in the court judgements, some boys switched off their computers, while others did not.

As often referred to in theoretical works, CMC also creates the opportunity for selective, or even dreamt up, self-representation. In Alex's case, his profiles were a substantial misrepresentation of his offline self. Most notably, he made the boys he contacted believe that he was a girl:

ALEX: As to my own story, I developed different profiles, which developed over time. Became a part of me. I now see that I had criminal intent. Didn't realise that at the time. I was tricking people. Tricking people into believing 
I was 'her'. And then I saved the photographs. Had images without asking. (Alex, in interview)

According to Alex, he used the Internet to become a young gay man. His online relations became an integral part of his adult sexuality. This way of using the Internet became like a game, with its own logic: 'You lose control, and the inner logic takes over' (Alex, in interview). In his reasoning, living as he was in a sexualised world as a young gay man, but with few known possibilities to explore his sexuality in the offline world, the virtual world became an opportunity more than a criminal activity.

ALEX: To me it wasn't dangerous. We went in and out of situations all the time. What was presented as abuse in the court judgements disappeared when switched to another situation. The police said, 'We're arresting you for rape'. That went over my head. I didn't understand. The media uses the term 'internet abuse'. That makes a distinction between the physical and what is not physical. I believe that makes sense to people. (Alex, in interview)

Thus, what Alex experienced in front of his computer differed from what the court classified as abuse and rape: a situation not dangerous nor illegal, but rather a situation that he could enter and leave as he wished. In addition, the virtual world influenced the way he understood his relationships with the boys he met on various social media platforms. The way he understood and described the situation, power, free will and the victims' feelings all point to deindividuation. As Alex understood the situation, his victims could have simply logged off, but only a few did. He thus 'played' a social game and did not problematise or reflect upon whether or not the boys he met on the Internet shared his understanding of the situation and of communication, despite the fact that he was misrepresenting himself by using fake profiles and posting as a girl.

In addition, the difference in temporal and spatial presence contributed to the blurring of social cues. There is a synchronicity when the offender and the victim have physical contact in a physical rape situation, whereas digital rapes are more often asynchronous. In Alex's case, he would send a request for sexualised pictures to a victim when that person was doing something else, such as sleeping or doing homework. Alex himself would then receive the photos or videos at another time, thus making the de facto rape occur asynchronously in time. Once, he got a 'Snap' (i.e. from the Snapchat platform) while he was eating dinner with his parents:

INTERVIEWER: You told me once that one of the rapes took place while you were having dinner with your parents; can you explain that?

ALEX: That had to do with time. I'd sent the threat an hour earlier, before I got the reply. I got a notification that I'd received a Snap. The rape is complete the moment the response arrives. The fact that a threat was sent defines it as an attempted rape. (Alex, in interview) 
Alex found it strange that some of the young people seemed interested in continuing to have contact with him on the Internet. This made him question if they all felt they had been raped, or if rape was also a construction that was made in court.

INTERVIEWER: You once told me that one of the victims in the case, after complaints had been filed, friended you on Facebook?

ALEX: The first guy I threatened, after a couple of years I sent him an apology. This was after the first police interview - about six months before I was remanded in custody. He immediately replied that he was okay and wanted to be friends on Facebook. [He didn't take any time] to consider. No hesitation. And he proceeded [to send me] some rather sexualised stuff. The guy was awarded a lot of money in court. The log detailing what I'm telling you was presented in court, but I don't feel they made much of a point of it. I think that some people [when they were questioned] were told that a conviction could entitle them to damages. I was convicted of several instances of raping the guy I'm telling you about now. (Alex, in interview)

\section{Court logics}

Previous studies on CMC have shown how communicating via a screen, as compared to F2F, can increase the testing and display of non-conforming behaviour and verbal aggression (e.g. Parks \& Floyd, 1996; Ybarra et al., 2007). Contrasting with Alex's views and descriptions, as presented above, are descriptions of his modus operandi as found in the court judgements. These texts make clear how the court and the victims understood Alex's behaviour as being planned and aggressive sexual behaviour:

The defendant has systematically and cynically taken advantage of each of the victims for his own sexual gratification. During each session, he has presented the individual victims with detailed instructions for participating in humiliating actions, and he has been the one in a position to end the event, or 'approve' it. He tricked the victims by saying it would be the last time, only to return multiple times and demand more. He ignored any plea not to have to do it; nor did he let comments about pain and blood grant the victims reprieve. He made all obey his orders, regarding when, where, and how. He paid no regard to individual boys' needs for sleep or homework, nor to their reluctance. He did not display any sign of empathy towards any of the boys while this was going on .... In their statements, many of the victims have talked about a feeling of powerlessness and of having no choice. They did not know who the offender was, when he might contact them again, or whether he would carry out his threats. Several of the victims even had their images published online. All of the victims expressed fear, difficulty sleeping, social isolation, and poorer school performance.

(Court judgement) 
From Alex's point of view, the sexual interactions were 'like a game'. The court saw this differently. According to the court judgements, the victims read Alex's behaviour as persuasion, deception and coercion:

The abuse of the underage boys has happened in their own homes and in their own private sphere. The victims experienced a situation of overhanging threat that for some lasted up to a year and a half, for others less. Either way, they have all lived with the continued fear of publication since the time of the first threat. He exerted his power over each of the victims, and he has taken advantage of their highly vulnerable age.

(Court judgement)

The concept of rape has become extended in recent years, and both law and court practice now view rape more seriously (Ryltoft Terjesen, 2016). In the introduction to this chapter, we assessed how rape is commonly understood as occurring through physical contact and temporal proximity of two or more people: one or more victims and perpetrators. Throughout history, rape has been linked to the actual physical meeting between victim and perpetrator. While other sexual crimes have been mediated - for instance, the unwanted depiction of nudity through photographs and films - rape as a particular category of sexual crime has been confined to F2F meetings. Against this background, it is interesting to note how one underlying conflict that arises from Alex's court case is the difference in understanding of whether online and offline forms of communication have different embedded qualities and affordances, which again influence how these interactions are understood across generations, structures and texts.

\section{Conclusion}

As previously discussed in this chapter, various studies have shown how online sexual engagement and exploration and even criminal offences among youth are a very common practice, and the borders between pubescent explorative engagements and illegal activities such as digital rape are often blurred. At the same time, digital rape is a serious sexual, often violent, crime that can have devastating and long-lasting consequences for its victims. Alex's case highlights some of the core challenges involved when digital, often generation-specific, transgressive practices cross boundaries, become illegal and encounter the world of courtrooms and legal provisions.

We can see how the courts, Alex and - if we accept the premises of Alex's own story - perhaps the victims themselves perceive the same situations as being serious crimes, but as different types of serious crimes. Thus, rather than offering a conclusion about rape by $\mathrm{CMC}$, as illustrated by the overlapping and contrasting narratives from Alex and the courts, we point to the challenges of providing a research-based approach to policy interventions, legal initiatives and the need to accept the complex nature of CMC. We must also develop a legal 
vocabulary that can be understood and legitimised, both by the Internet generation and beyond.

\section{Notes}

1 Unofficial translation of the Norwegian version of the act, as provided for information purposes by the Ministry of Justice and Public Security. See https://lovdata.no/doku ment/NLE/lov/2005-05-20-28 for the full version of the penal code.

2 In the new Norwegian Penal Code $\$ 291$, rape is defined as (a) having sexual intercourse through violence or threatening behaviour; (b) having sexual relations with someone who is unconscious or for other reasons is unable to oppose the action; or (c), through violence or threatening behaviour, making somebody have sexual intercourse with another, or to perform acts that correspond to sexual intercourse with oneself. The crime is punishable by up to 10 years in prison.

3 This research project has been conducted and financed by the University College of Norwegian Correctional Service (KRUS, for Kriminalomsorgens høgskole og utdanningssenter).

4 One of the co-authors (Martinsen) conducted the interviews.

5 One of the co-authors (Staksrud) was not involved in the application to NSD or in the collection of the empirical data.

6 Going into details on his situation would weaken his anonymity.

\section{References}

Back, Mitja D., Schmukle, Stefan C., \& Egloff, Boris. (2008). How extraverted is honey.bunny77@hotmail.de? Inferring personality from e-mail addresses. Journal of Research in Personality, 42(August 2008), 116-1122. doi: https://doi.org/10.1016/j.jrp.2008.02.001

Badenhorst, C. (2011). Legal responses to cyber bullying and sexting in South Africa. Centre for Justice and Crime Prevention (CJCP) issue paper, 10, 20.

Bulger, M., Burton, P., O’Neill, B., \& Staksrud, E. (2017). Where policy and practice collide: Comparing US, South African and European Union approaches to protecting children online. New Media \& Society, 19(5), 750-764. doi: 10.1177/1461444816686325

Choo, K.-K. R. (2009). Online child grooming: A literature review on the misuse of social networking sites for grooming children for sexual offences. AIC Reports Research and Public Policy Series. Canberra: Australian Institute of Criminology.

Council of Europe. (2001). Convention on Cybercrime. Budapest. Retrieved from http:// conventions.coe.int/Treaty/EN/Treaties/HTML/185.htm

Deleuze, G., \& Guattari, F. (1987). A thousand plateaus: Capitalism and schizophrenia. Minneapolis: University of Minnesota Press.

Derks, D., Bos, A. E. R., \& von Grumbkow, J. (2008). Emoticons in computer-mediated communication: Social motives and social context. CyberPsychology \& Behavior, 11(1), 99-101. doi: 10.1089/cpb.2007.9926

Drouin, M., Ross, J., \& Tobin, E. (2015). Sexting: A new, digital vehicle for intimate partner aggression? Computers in Human Behavior, 50, 197-204. doi: 10.1016/j. chb.2015.04.001

Finkelhor, D., Mitchell, K. J., \& Wolak, J. (2000). Online victimization: A report on the nation's youth. Retrieved from www.missingkids.com

Game, A. (1991). Undoing the social: Towards a deconstructive sociology. Buckingham, UK: Open University Press. 
Gottschalk, P. (2011). Stage model for online grooming offenders. In J. Davidson \& P. Gottschalk (Eds.), Internet child abuse: Current research and policy (pp. 79-103). Abingdon, UK: Routledge.

Handyside, S., \& Ringrose, J. (2017). Snapchat memory and youth digital sexual cultures: Mediated temporality, duration and affect. Journal of Gender Studies, 26(3), 347-360.

Henry, N., \& Powell, A. (2015). Embodied harms: Gender, shame, and technology-facilitated sexual violence. Violence against Women, 21(6), 758-779.

Hvinden, B., Enebakk, V., Fjørtoft, K., Holand, I., Johnsen, R., Kolstad, I., \& Monsen, T. H. (2016). Guidelines for research ethics in the social sciences, humanities, law and theology. Oslo: Norwegian National Committees for Research Ethics.

Kierkegaard, S. (2008). Cybering, online grooming and ageplay. Computer Law \& Security Report, 24(1), 41-55. doi: 10.1016/j.clsr.2007.11.004

Kiesler, S., Siegel, J., \& McGuire, T. W. (1984). Social psychological-aspects of computer-mediated communication. American Psychologist, 39(10), 1123-1134. doi: 10.1037//0003-066x.39.10.1123

Klettke, B., Hallford, D. J., \& Mellor, D. J. (2014). Sexting prevalence and correlates: A systematic literature review. Clinical Psychology Review, 34(1), 44-53. doi: 10.1016/ j.cpr.2013.10.007

Martinsen, T. J. (2016). Der blodet bruser og ting skjer. Master's thesis. Lillehammer: Inland Norway University of Applied Sciences.

Mascheroni, G., Vincent, J., \& Jimenez, E. (2015). 'Girls are addicted to likes so they post semi-naked selfies': Peer mediation, normativity and the construction of identity online. Cyberpsychology: Journal of Psychosocial Research on Cyberspace, 9(1), article 5. doi: 10.5817/CP2015-1-5

McKenna, K. Y. A., \& Bargh, J. A. (2000). Plan 9 from cyberspace: The implications of the internet for personality and social psychology. Personality and Social Psychology Review, 4(1), 57-75. doi: 10.1207/s15327957pspr0401_6

Parks, M. R., \& Floyd, K. (1996). Making friends in cyberspace. Journal of Communication, 46(1), 80-97. doi: 10.1111/j.1460-2466.1996.tb01462.x

Peter, J., Valkenburg, P. M., \& Schouten, A. P. (2006). Characteristics and motives of adolescents talking with strangers on the internet. CyberPsychology and Behaviour, 9(5), 526-530.

Renfrow, D. G., \& Rollo, E. (2014). Sexting on campus: Minimizing perceived risks and neutralizing behaviors. Deviant Behavior, 11(35), 903-920.

Ryltoft Terjesen, J. (2016). Straffeideologi i endring? En studie av vår tids straffeideologi, slik den kommer til uttrykk i kriminalpolitikken på voldtektsfeltet. Master's thesis, Faculty of Law, Institute of the Criminology and Sociology of Law, University of Oslo.

Sandberg, S. (2013). Are self-narratives strategic or determined, unified or fragmented? Reading Breivik's manifesto in light of narrative criminology. Acta Sociologica, 56(1), 69-83.

Siegel, J., Dubrovsky, V., Kiesler, S., \& McGuire, T. W. (1986). Group processes in computer-mediated communication. Organizational Behavior and Human Decision Processes, 37(2), 157-187. doi: 10.1016/0749-5978(86)90050-6

Staksrud, E. (2013). Online grooming legislation: Knee-jerk regulation? European Journal of Communication, 28(2), 152-167. doi: 10.1177/0267323112471304

Staksrud, Elisabeth, \& Olafsson, Kjartan. (2019). Tilgang, bruk, risiko og muligheter, Norske barn på Internett. Resultater fra EU Kids Online Undersøkelsen i Norge 2018 (s. 82). Oslo: Institutt for medier og kommunikasjon, Universitetet i Oslo. https://www.uio. 


\section{Elisabeth Fransson et al.}

no/english/research/strategic-research-areas/nordic/research/research-groups/living-thenordic-model/news/eu-kids-online-hovedrapport-for-norge-2019.pdf

Staksrud, E., Ólafsson, K., \& Livingstone, S. (2013). Does the use of social networking sites increase children's risk of harm? Computers in Human Behavior, 29(1), 40-50. doi: $10.1016 /$ j.chb.2012.05.026

Taylor, J. (2011). Policing social networking sites and online grooming. In J. Davidson \& P. Gottschalk (Eds.), Internet child abuse: Current research and policy (pp. 126-152). Abingdon, UK: Routledge.

United Nations. (1989). UN Convention on the Rights of the Child entry into force, 2 September 1990, in accordance with article 49. Retrieved from www2.ohchr.org/english/ law/crc.htm

Van Ouytsel, J., Walrave, M., Ponnet, K., \& Heirman, W. (2015). The association between adolescent sexting, psychosocial difficulties, and risk behavior: Integrative review. Journal of School Nursing, 31(1), 54-69. doi: 10.1177/1059840514541964

Walther, J. B. (1996). Computer-mediated communication. Communication Research, 23 (1), 3-43. doi: 10.1177/009365096023001001

Widerberg, K. (2001). Historien om et kvalitativt forskningsprosjekt. Oslo: Universitetsforlaget.

Wolak, J., Finkelhor, D., \& Mitchell, K. J. (2012). How often are teens arrested for sexting? Data from a national sample of police cases. Pediatrics, 129, 4-12.

Wolak, J., Finkelhor, D., Mitchell, K. J., \& Ybarra, M. L. (2008). Online 'predators' and their victims. American Psychologist, 63(2), 111-128.

Ybarra, M. L., Espelage, D. L., \& Mitchell, K. J. (2007). The co-occurrence of internet harassment and unwanted sexual solicitation victimization and perpetration: Associations with psychosocial indicators. Journal of Adolescent Health, 41(6), S31-S41. 


\title{
13 Digital sexual violence \\ Image-based sexual abuse among Danish youth
}

\author{
Sidsel Kirstine Harder, Kathrine Elmose Jørgensen, \\ Jonathan Priesholm Gårdshus and Jakob Demant
}

\section{Introduction}

Researchers, practitioners and policy-makers within the Nordic countries and elsewhere are currently addressing the non-consensual distribution of digital sexual images among young people. Studies have shown that previous campaigns against this new offence have created fear, rather than leading to 'safe sexting' as intended (Albury, Hasinoff \& Senft, 2017; Powell \& Henry, 2014). The field has a dire need for research on the characteristics of the young people who commit these crimes in order to better prevent image-based sexual abuse. In this chapter, we investigate such abuse by analysing its correlation with self-control and risk-oriented opportunities; the latter include variables that are relevant to establishing frameworks for prevention efforts.

To date, the emerging international body of research on the consensual digital sharing of sexual images has been focussed within the English-speaking world, with a majority of studies examining the risks of images being forwarded without the depicted person's consent. Powell and Henry (2016, 2017) have investigated the victimisation prevalence of technology-facilitated sexual violence and have stressed the importance of studying the prevalence of offending. With important exceptions, such as the work of Langlois and Slane (2017) and DeKeseredy and Schwartz (2016), few studies have looked into the causes and enablers of offending, and neither of these two studies sought to measure prevalence quantitatively (Henry \& Powell, 2018). The lack of knowledge about what drives offenders could pathologise this group; it could also mean that practitioners risk missing out on important intervention points for the prevention of sexual violence in the digital sphere (Jørgensen, 2017).

Criminological researchers have underscored the importance of investigating levels of self-control among offenders of different forms of crime and have shown that poor self-control correlates with criminal behaviour (Grasmick, Tittle, Bursik \& Arneklev, 1993; Reyns, Henson \& Fisher, 2014). The aim of this paper is to investigate what characterises image-based sexual abuse offenders by examining the influence of self-control in conjunction with opportunities. We use quantitative survey data drawn from a Danish youth population to analyse some of the factors that predict the probability of sharing sexual images non-consensually. By 
doing so, we seek a better sense of both the individual and social factors linked to committing this new form of crime.

\section{Defining image-based sexual abuse}

The digital sharing of sexual images is an emerging practice, and researchers are still defining and debating the concepts necessary for studying this new form of digital sexual behaviour (Barrense-Dias, Berchtold, Surís \& Akre, 2017). Generally, 'sexting' refers to the consensual sharing of sexual images (or text messages) digitally; Drouin, Vogel, Surbey and Stills (2013, p. 25) define this practice as the 'transmission of sexual material' via phone or the Internet. But different scholars use different specifications of terms (Döring, 2014; Renfrow, Kucewicz, Mouradian \& Schweigert, 2017; Walker \& Sleath, 2017) regarding consent (to receive, send, distribute), content (nudity, or a lack of underwear or the wearing of intimate apparel), form (images, videos, text), activity (sharing, receiving, sending/posting, exchanging) and media/sharing tools (digital media/social network sites [SNS], phones, the Internet).

For the non-consensual sharing of sexual images, several unifying concepts for describing this new type of crime are consolidating presently. We use 'image-based sexual abuse' because the concept focusses concretely on the activity of images being shared without consent; this concept has recently become consolidated and is now among the most used concepts in the field (Maddocks, 2018).

McGlynn, Rackley and Houghton (2017, p. 28) developed the notion of image-based sexual abuse by drawing on Kelly's (2013) development of a continuum for sexual violence. Kelly defines sexual violence as including

any physical, visual, verbal or sexual act that is experienced by the woman or girl, at the time or later, as a threat, invasion or assault, that has the effect of hurting her or degrading her and/or takes away her ability to control intimate contact.

(2013, p. 41).

Kelly expands the definition of sexual violence beyond the use of physical power and links different kinds of sexual violence to one another. By defining image-based sexual abuse as the 'non-consensual creation and/or distribution of private sexual images', McGlynn and colleagues (2017, p. 27) conceptualise a continuum of different kinds of sexual violence related to digital images while also linking such violence to other kinds of sexual violence. The term 'abuse' conveys harm to victims/survivors rather than evoking connections to child exploitation, as found in Henry and Powell's closely related definition of 'image-based sexual exploitation' (Henry \& Powell, 2015; Powell \& Henry, 2017).

Henry and Powell's definition (2018) is a sub-concept under the term 'technology-facilitated violence'. They link their concept to the World Health Organization's 
(2012, p. 2) definition of sexual violence as encompassing 'unwanted sexual comments or advances [...] against a person's sexuality using coercion'. By sharing personal sexual images without consent, depicted people lose their ability to control for whom they appear in intimate circumstances. Previous research has shown that being exposed to image-based sexual abuse can lead to a range of harmful consequences, ranging from 'trust issues, post-traumatic stress disorder (PTSD), anxiety, depression, suicidal thoughts, and several other health effects' (Bates, 2017, p. 22); some of these other effects include negative coping mechanisms related to alcohol or drugs and victim blaming (Korenis \& Billick, 2014; Walker \& Sleath, 2017; Wolak \& Finkelhor, 2011). We can compare these consequences to those of other forms of sexual violence, which further underlines the relevance of using the concept of image-based sexual abuse to place the non-consensual sharing of sexual images within this terminology.

The common purpose behind the numerous and synonymous concepts of image-based sexual abuse is to resist the popular term 'revenge porn'. Maddocks (2018) argues that this renaming is itself an activist practice: by resisting the word 'revenge', one can counter victim blaming by pointing to the variety of motives behind the non-consensual sharing of digital sexual images (see also Bates, 2017). Those in the field resist the vocabulary of 'pornography' because the use of terms for legal sexual material risks legitimising non-consensual image sharing. Activists' use of the term 'digital rape' instead problematises the online/offline distinction between types of sexual violence. While the use of the word 'pornography' risks equating different kinds of sexual activities, the use of the term 'rape' risks conflating image sharing with physical abuse. The intention is instead to link different abusive behaviors together as sexual violence; that linkage thus becomes another common denominator for the different concepts that currently designate non-consensual image sharing (Maddocks, 2018).

\section{Previous research and scope of analysis}

While non-consensual image sharing is illegal, researchers to date have primarily explored such sharing as a cultural and everyday phenomenon (e.g. Cooper, Quayle, Jonsson \& Svedin, 2016; Handyside \& Ringrose, 2017; Richards \& Calvert, 2009; Ringrose, Harvey, Gill \& Livingstone, 2013) rather than as a criminological research area. We address this research gap by drawing on criminological self-control theory combined with an opportunity perspective that includes the role of situational factors. We assume that engaging in certain practices - such as sending/receiving nude photos, having unprotected sex, and binge drinking - can lead to increased opportunities to commit image-based sexual abuse.

To investigate the influence of self-control on such abuse, we apply the classical framework within Gottfredson and Hirschi's general theory of crime (1990). According to this theory, crime is motivated by self-interests. Those who have little self-control are thus more likely to commit crime because they 
fail to consider what negative consequences their actions might have, as the attainment of personal gain overshadows any considerations of the possible juridical, social and personal consequences. In Gottfredson and Hirschi's understanding (1990), self-control is hence not simply related to deviant acts that lead to consequences in a juridical context. As Grasmick et al. (1993, p. 9) argue, 'Criminality, therefore, is subsumed under the personality trait [of] low self-control, but low self-control also predisposes people to engage in certain other kinds of irresponsible behaviors'.

Support for this approach to image-based sexual abuse may be found in a study of consensual sexting among college students conducted by Reyns and colleagues (2014), who argue that poor self-control is a predictor of consensual sexting, because people with poor self-control will be less likely to consider possible negative consequences. We extend their argument to imply that selfcontrol is even more relevant to the criminal act of forwarding sexual images of others against their consent than to sexting images of oneself. People with little self-control may be more likely to sext, and their lack of self-control will also make them more likely to offend. We thus hypothesise that poor self-control will make the offense of image-based sexual abuse more likely to happen out of a need for instant gratification and personal interests and a lack of consideration of the negative consequences.

According to Gottfredson and Hirschi (1990), poor self-control is caused by specific early-childhood experiences, mainly within the context of the family, but Reyns and colleagues (2014) also stress integration with a more opportunity-oriented framework that goes back to the classic work of Cohen and Felson (1979). Drawing on victimisation research, Reyns and colleagues (2014, p. 279) state that poor 'self-control should directly influence participation in sexting, but $[\ldots]$ lifestyles and routine activities should mediate some of this effect'. They stress that not only someone's personal makeup, but also everyday risk routines, will make criminal behaviour more likely to occur. Inspired by Reyns and colleagues (2014), we draw on a more sociological definition of self-control that also takes into account those situational and social factors that can mediate the association between self-control and offending. Even when self-control is a stable trait, everyday lifestyles and routines are important supplements in explaining both consensual and non-consensual image sharing.

The situational and social factors incorporated into our study consist of two types of risk behaviours: online and offline. The first pertains to other sexting behaviours, namely the sending of consensual sexual imagery of oneself and the receiving of sexual images of others without their consent. The second form of risk behaviour includes offline risks pertaining to binge drinking and unsafe sexual activity. Previous studies have shown that (1) alcohol use is connected to sexual image sharing (Dake, Price, Maziarz \& Ward, 2012), (2) offending is likely to happen during drunken situations and (3) offenders tend to get drunk more often than non-offenders (Klettke, Hallford \& Mellor, 2014). These findings are especially interesting in the Danish cultural context, where alcohol has a central place in youth leisure activities (Demant \& Østergaard, 2007). 
Previous research has unanimously shown that being sexually active increases the probability of sexting and that unsafe sex and other types of sexual risktaking are connected to sexting (Klettke et al., 2014), all of which leads to our hypothesis that sexual activity both online and offline will increase the probability of engaging in image-based sexual abuse. We thus assume that non-digital risk behaviours such as heavy alcohol consumption and sexual activity can likely increase the probability for image-based sexual abuse, as these are situations where sexual images can be produced and shared.

\section{Hypotheses}

Figure 13.1 schematically illustrates the relationships between self-control, opportunities and offending. As shown in the figure, we assume that self-control is linked to offending both independently and through opportunity variables, and that all variables are linked to age and gender.

We expect self-control to vary with demographic characteristics such as age and gender, as will the proportion of people who offend. Given the theoretical considerations on opportunities noted above, we also control for variables that measure drinking, consensual online/offline sexual activity and the nonconsensual receipt of sexual images. Following Reyns and colleagues' (2014) model, we use sexting consensually and receiving non-consensually as two of our opportunity measures.

We expect people with poor self-control to more often be involved in activities that will give them opportunities to become offenders, which would result in a negative raw correlation between self-control and offending. In controlling for mediating opportunity variables, we ask whether self-control still has an influence even when people have been in opportune offending situations.

\section{Empirical strategy}

Our main research question asks about the influence of self-control, mediated by opportunities, on one's propensity to become an offender of image-based sexual abuse. We employ a logistic regression model in order to estimate the probabilities of sexting, given a score on the Brief Self-Control Scale, or BSCS

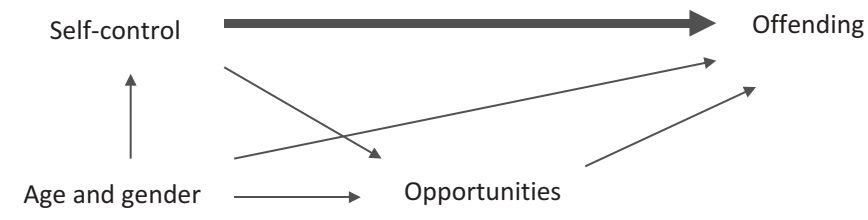

Figure 13.1 Model showing the relation between independent, dependent, background and mediating variables. 
(Tangney, Baumeister \& Boone, 2004), with standard errors clustered by institution. Regression estimates are presented in an odds ratio (OR). Figure 13.2 shows the predicted probabilities at selected values.

To assess the interplay of the relationship between self-control while controlling for demographic confounders and allowing for possibly mediating opportunity variables, we include control variables in two steps, as discussed by Aneshensel (2013). First, we estimate the relationship between self-control and offending, controlling for gender and age; second, we add the four opportunity variables to the model. The full model should provide an estimate of a direct effect of self-control independently of the other explanatory variables. A coefficient of self-control that changes between the two models would indicate mediation.

\section{Data}

Our data is drawn from a survey conducted and administrated by a partnership between several municipalities, research institutions and universities in Denmark (Dahl, Henze-Pedersen, Østergaard \& Østergaard, 2018). In 2017, more than 60,000 young Danes responded to a survey on various health and social issues. The survey was collected by individual municipalities; since the process and selection varied between municipalities, properly investigating the representivity of the sample is impossible (Svendsen, 2018). Our sample consists of 61,289 Danes between the ages of 12 and 25, enrolled in either lower secondary school or secondary school, ${ }^{1}$ who responded to every item used in the regression. Of the whole sample, the proportion who did not respond to the question about the non-consensual sharing of sexual images varied only slightly between educational status, with the lowest being $4.3 \%$ in common upper secondary schools and the highest being 5.9\% among technical upper secondary schools. Of those aged 14 (the most frequent age in our sample), 51.3\% were male. While this percentage was not significantly different from the $51.4 \%$ of all Danes aged 14 who are male, there were most likely numerous non-responses, which may have caused unaccounted-for bias.

\section{Primary variables}

Table 13.1 lists the range, average and standard deviations (SDs) of the variables included in our analysis.

The dependent variable measures image-based sexual abuse by asking whether the respondent had 'shared a sexual image/video of others within the last 12 months, e.g. in their underwear or nude, without their consent' (emphasis by italics and underlining in the questionnaire). Response options were 'yes', 'no', and 'don't know'. In our sample, 3.4\% of the respondents were image-based sexual abuse offenders.

The primary independent variable is a psychometric scale that measures selfcontrol. In our survey, self-control was measured by the BSCS (Tangney et al., 
Table 13.1 Summary statistics of all variables included in the models.

\begin{tabular}{lccccc}
\hline & Count & Min & Max & Mean & SD \\
\hline $\begin{array}{l}\text { Shared image of others without their consent } \\
\text { (offender) }\end{array}$ & 61,289 & 0 & 1 & 0.03 & 0.18 \\
Self-control & 61,289 & -2.11 & 1.26 & 0.00 & 0.50 \\
Male & 61,289 & 0 & 1 & 0.47 & 0.50 \\
Age & 61,289 & 12 & 25 & 15.74 & 2.19 \\
Safe sex & 61,289 & 0 & 1 & 0.28 & 0.45 \\
Unsafe sex & 61,289 & 0 & 1 & 0.05 & 0.23 \\
Shared image of one self (sexter) & 61,289 & 0 & 1 & 0.13 & 0.33 \\
Drunk 3+ times & 61,289 & 0 & 1 & 0.09 & 0.28 \\
Received image & 61,289 & 0 & 1 & 0.14 & 0.35 \\
\hline
\end{tabular}

2004). We use a reduced version of the scale with 13 items, an example of which is 'Sometimes I take a risk, because it's fun'. All items were answered on the same four-point Likert-type scale of 'completely agree', 'slightly agree', 'slightly disagree', and 'completely disagree'. In our measurement, we used Gelman's scaling for regressions, where the standardised measure is divided by two SDs (instead of the usual one) in order to make the coefficients' directly comparable to untransformed binary predictors' (2008, p. 2865) such as gender. The comparability only applies to binary variables with a mean of around 0.5 and thus does not apply to our opportunity variables, which are very skewed (Gelman, 2008). The scaling means that a one-unit change (e.g. from 0 to 1) of two SDs is approximately equivalent to answering each of the 13 questions that measure self-control by one step either higher or lower (e.g. from 'slightly agree' to 'slightly disagree'). Our measure is approximately normally distributed and includes very few respondents with either extremely high or extremely low self-control values.

\section{Background and opportunity variables}

Our model controls for the influences of sex and age. Age and gender were self-reported, and the sample consists of $47.3 \%$ boys and men. While the age ranges from 12 to 25, most respondents were between 13 and 19 years old, with an average of 15.7 years $(\mathrm{SD}=2.2)$. Slightly over half $(51 \%)$ of our respondents were in elementary school.

\section{Often binge drinking}

The respondents were asked: 'Think about the past 30 days. How many times have you been drunk from drinking alcoholt? E.g. had difficulties walking 


\section{Sidsel Kirstine Harder et al.}

straight, not been able to talk clearly, vomited, or had difficulties remembering what went on?' They were given six response options, ranging from none to more than ten times. To measure binge drinkers, we chose those respondents who reported to have been drunk three or more times during the past month, which encompasses $9 \%$ of the sample.

\section{Sexual activity}

The respondents were asked if they 'had ever had intercourse', with response options of 'yes' and 'no'. The 44\% who had had sexual experiences were asked which kind of contraception (if any) they had used during their most recent intercourse, with the following response options:

- 'no contraception', 'safe periods', or 'interrupted intercourse' (these three options were coded as 'unsafe sex' and included 5\% of the population);

- 'condoms' or 'birth-control pills' (these two options were coded as 'safe sex' and included $28 \%$ of the population); or

- 'other' (not included).

We hypothesise that being sexually active - in particular having unsafe sex during the most recent intercourse - will increase the risk of committing imagebased sexual abuse.

\section{Sexting}

The respondents were asked, 'Within the last 12 months, have you shared a sexual image/video of yourself, for example in your underwear or nude?' (emphasis in the questionnaire). The response options were 'yes', 'no' and 'don't know'. The $12.5 \%$ of both genders who answered 'yes' were coded as sexters.

\section{Receiving digital sexual images}

The respondents were asked, 'Within the last 12 months, have you received a sexual image/video of someone else, for example nude or only wearing underwear, where the other person did not give his or her permission?' The response options were 'yes', 'no' and 'don't know'; 14\% answered that they had received images without the consent of the pictured person.

\section{Results}

\section{Descriptive results}

We found significant differences between offenders and non-offenders for both self-control and every situational variable. Among binge-drinking respondents, 
$10 \%$ were offenders of image-based sexual abuse, which was significantly more than the figure of $3 \%$ among those who did not binge drink often. At the same time, the binge drinkers had significantly poorer average self-control $(-0.23$ compared with 0.02). The differences in distributions for offending and selfcontrol for those who had had unsafe sex were very similar to the patterns for binge drinkers, which indicates that the offenders were characterised by different offline sexual and social activities as well as lower levels of self-control compared to the rest of the population.

These differences were even more striking when we move from offline behaviours to looking at offenders' digital sexual activities. Among people who had sexted, 14\% had also committed image-based sexual abuse, compared to $2 \%$ of those who did not sext. Sexters also had poorer self-control $(-0.17$ compared with 0.02). The difference was even more significant for receiving nonconsensual images, which was highly correlated with offending through imagebased sexual abuse: of those who received images, almost one-fifth had also offended, whereas only $1 \%$ of the youth who did not receive images nonconsensually had offended. Image receivers also had poorer self-control $(-0.23$ compared with 0.04). The descriptive analysis of our sample of the Danish youth population agrees with previous findings on self-control from sexting research.

Before turning to estimating models, we will first present a descriptive overview of the relationships between all the variables we included in the analysis. Table 13.2 below presents the pairwise correlations of the variables in a correlation matrix; as the table shows, most of the pairwise correlation coefficients range between 0.10 and 0.25 (in absolute values). The strongest correlations are between age and safe sex and between receiving images and sharing images without consent. For gender, all correlations with opportunity variables are less than 0.10 ; other very weak correlations are safe sex, with both offending and self-control. The correlation between offending and self-control is

Table 13.2 Pairwise correlation coefficients of all the variables included in the study.

\begin{tabular}{|c|c|c|c|c|c|c|c|c|c|}
\hline & 1 & 2 & 3 & 4 & 5 & 6 & 7 & 8 & 9 \\
\hline 1. Offender & - & & & & & & & & \\
\hline 2. Self-control & -0.16 & - & & & & & & & \\
\hline 3. Male & 0.11 & -0.18 & - & & & & & & \\
\hline 4. Age & 0.03 & 0.04 & -0.01 & - & & & & & \\
\hline 5. Safe sex & 0.05 & -0.05 & -0.05 & 0.49 & - & & & & \\
\hline 6. Unsafe sex & 0.12 & -0.11 & 0.08 & 0.22 & -0.15 & - & & & \\
\hline 7. Sexter & 0.23 & -0.13 & -0.00 & 0.16 & 0.27 & 0.13 & - & & \\
\hline 8. Drunk $3+$ times & 0.12 & -0.14 & 0.03 & 0.20 & 0.22 & 0.14 & 0.13 & - & \\
\hline 9. Received image & 0.34 & -0.19 & 0.07 & 0.05 & 0.12 & 0.11 & 0.23 & 0.13 & - \\
\hline
\end{tabular}




\section{Sidsel Kirstine Harder et al.}

-0.16 . When we move on to the multiple regression analysis, we will primarily focus on the relationship of these two variables while controlling for the correlations of the others.

\section{Regression models}

Table 13.3 presents estimates of the two models. Our key finding is that offending covaries negatively with self-control, and although some of the effect is mediated by opportunity variables, self-control also has an effect independently of these variables.

We now look at the coefficients and influences of the other explanatory variables in the model. Model 1 shows that the effect of self-control is smaller than the effect of gender, as the odds of offending are almost three times higher for men than for women. Our findings show that male respondents on average are more likely to become offenders, which is also true when controlling for the gendered differences in self-control, drinking behaviour and online/offline sexual activity in model 2.

Age is highly significant when modelled without opportunity variables, so although the OR is low, the probability of committing image-based sexual

Table 13.3 Regression table presenting estimates in odds ratios for the two models. Standard errors are clustered by institution

\begin{tabular}{llclc}
\hline & \multicolumn{2}{c}{ (Model 1) } & \multicolumn{2}{c}{ (Model 2) } \\
\cline { 2 - 5 } & \multicolumn{2}{c}{$\begin{array}{c}\text { Shared sexual images } \\
\text { non-consensually }\end{array}$} & $\begin{array}{c}\text { Shared sexual images } \\
\text { non-consensually }\end{array}$ \\
\cline { 2 - 5 } & OR & CI 95\% & OR & CI 95\% \\
\hline $\begin{array}{l}\text { Standardised values of Brief } \\
\text { Self-control }\end{array}$ & $0.22^{* * *}$ & {$[0.21,0.24]$} & $0.42^{* * *}$ & {$[0.38,0.46]$} \\
Male & $2.90^{* * *}$ & {$[2.57,3.27]$} & $2.96^{* * *}$ & {$[2.64,3.32]$} \\
Age & $1.10^{* * *}$ & {$[1.07,1.13]$} & $0.97 *$ & {$[0.94,1.00]$} \\
Safe sex & & & 1.06 & {$[0.92,1.22]$} \\
Unsafe sex & & & $1.88^{* * *}$ & {$[1.58,2.24]$} \\
Send own sexual images & & & $3.95 * * *$ & {$[3.53,4.42]$} \\
Drunk 3+ times & & & $1.60^{* * *}$ & {$[1.41,1.83]$} \\
Received images & & & $12.72^{* * *}$ & {$[11.33,14.27]$} \\
non-consensually & & & 0.00 & \\
Constant & & & 61,289 & \\
Observations & & & 0.342 & \\
Pseudo R & & & & \\
\hline
\end{tabular}

* $\mathrm{p}<0.05$,

$* * \mathrm{p}<0.01$

$* * * \mathrm{p}<0.001$ 
abuse increases throughout adolescence. In model 2, however, the OR of age is slightly lower than 1 and is only just significant, at the 5\% level. Hence, it is not the effect of age alone that heightens the probability of offending; rather, the more important predictor is that people will have more opportunities to offend the older they get.

Adding the opportunity variables lowers the effect of self-control substantially: from an OR of 0.22 in model 1 to 0.42 in model 2 . The $95 \%$ confidence intervals of self-control in models 1 and 2 do not overlap, so we may conclude that the drop in effect is statistically significant. This finding suggests that opportunities mediate a considerable part of selfcontrol's effect on the probability of offending, in that some of the effect of self-control on sexting has to do with the way in which poor selfcontrol brings about opportunities for committing image-based sexual abuse in the sexual or social sense. Receiving images in particular is a very strong predictor, but the other opportunity variables also show significant effects. Receiving images increases the odds of offending by 13 times, sexting increases the odds by four times and having unsafe sex increases the odds by 1.9 times (while having safe sex rather than not having sex does not increase the risk of offending); finally, being drunk often increases the odds by 1.6 times. The full model explains around a third of the variation in offending, but most of the explanatory power comes from the 'receiving images' variable.

Figure 13.2 shows the predicted probabilities for offending, dependent on self-control and based on the full model. We have chosen values for the other independent variables to be these variables' modal values (female, age 14, sexually inexperienced, not binge drinking, not sexting), except that we chose 'did receive images non-consensually', since very few people offend if they have not received images. ${ }^{2}$ Other than the 'having received images' variable, these values are also those associated with a low probability of offending. Even though self-control on its own explains very little of the variation of offending - for example, including only this variable yielded a very low pseudo $\mathrm{R}^{2}$ of 0.08 - when we looked at averages, we found a significant and substantial difference: the risk of offending was much higher for those with poor self-control compared to those with better self-control. As Figure 13.2 shows, when we look across the young people in our sample, those with very poor self-control $(-1)$ had a predicted probability of offending of around $10 \%$, compared to around $2 \%$ for those with very good self-control (1).

Variables are held at their modal values (female, age 14, sexually inexperienced, not bingedrinking, not sexting) except received (has received). The line is the expected probability, and the area is the $95 \%$ confidence interval. 


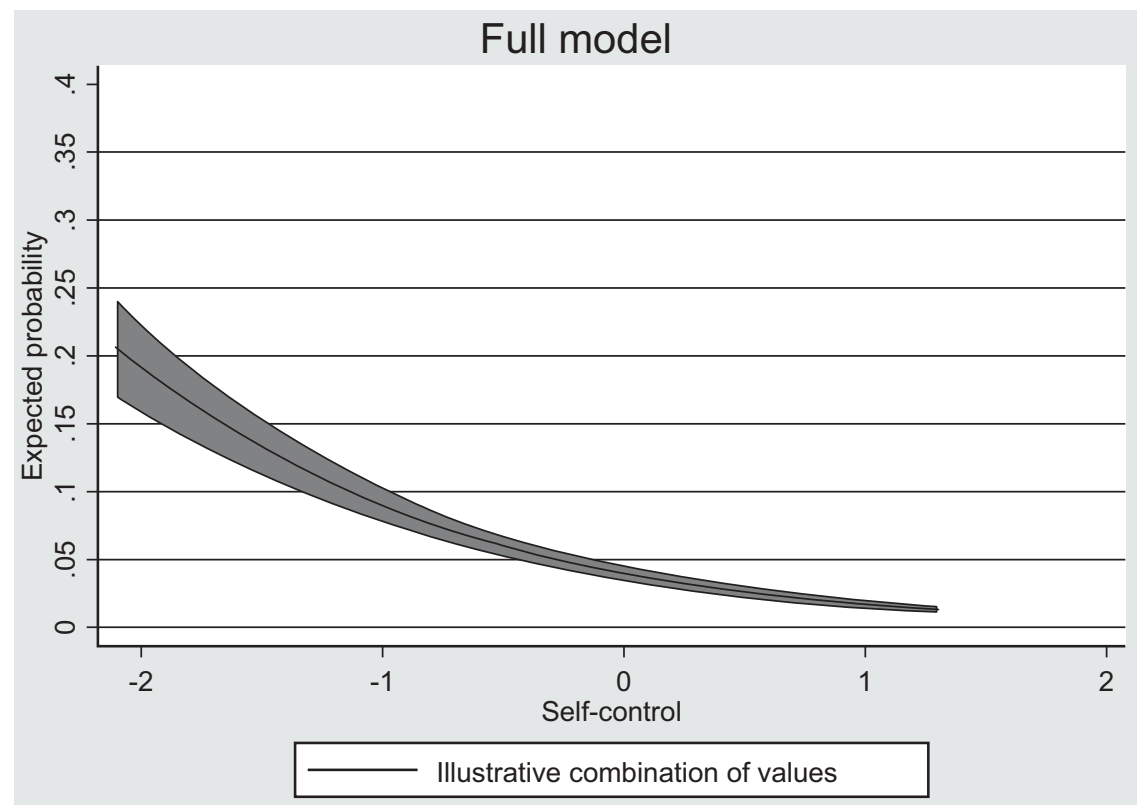

Figure 13.2 The predicted probabilities for offending dependent on self-control, based on regression estimates of the full model.

\section{Discussion}

This chapter builds on a distinction between consensual and non-consensual forms of digital sexual interaction and the conceptualisation of image-based sexual abuse as a type of sexual violence. The study contributes to the field's understanding of these connections by investigating image-based sexual abuse in a criminological framework of self-control and by analysing the covariations with consensual forms of sexting and online/offline risk behaviours.

As Albury and Crawford have shown, consensual sexting, or 'the act of taking and transmitting naked or semi-naked pictures via mobile phones' (2012, p. 463), and non-consensual sharing too often become conflated under the headline of 'child pornography', thus leaving no space for young people to consent to or express and enjoy their own sexuality digitally. Lack of consent is key to the definition of image-based sexual abuse and is what separates such abuse from mainstream non-violent sexual practices. Although the term 'image-based sexual abuse' emphasises that the nonconsensual exchange of sexual images is conceptually different from sexting, our empirical model shows that the two practices are correlated, as it is more common to offend if one is also a sexter. While other studies have examined the relationships between different kinds of sexting behaviour (Mitchell, Finkelhor, Jones \& Wolak, 2012; Patrick, Heywood, Pitts \& Mitchell, 2015), our analysis shows that receiving 
images is strongly correlated with offending via image-based sexual abuse: of those who had received images, almost a quarter had also offended. In contrast, only $1 \%$ of the youth who had not received images had offended.

One characteristic that the offenders, sexters and receivers in our sample have in common is that on average they had poorer self-control compared to the other respondents. We have shown that self-control has a moderate effect on image-based sexual abuse, and we compared this effect to the effects of gender, age and opportunity variables. Our findings are in accordance with the general theory of crime as well as research that has linked self-control to criminal and deviant practices. Qualitative studies of the normalisation of sexual-image exchange have described this practice as being embedded in the everyday lives of young people. In addition to this insight, our contribution to the literature is to emphasise that image-based sexual abuse offenders may be characterised by one or more of the various important personality traits that mark other types of deviance. Our analysis has extended Reyns and colleagues' (2014) work on self-control and sexting by emphasising that self-control is not only linked to consensual sexting practices but also has a significant effect on the propensity of committing image-based sexual abuse, and that poor self-control further heightens the probability of offending in itself.

The few studies that have been conducted on image-based sexual abuse offenses to date have focussed on the affordances of technology (Langlois \& Slane, 2017) or on the problematics of masculinity (DeKeseredy \& Schwartz, 2016) as having impacts on men who share digital sexual images non-consensually. Technological and gendered dynamics are often seen to work together to exaggerate the tendencies of online rape culture (Powell \& Henry, 2017). Our study contributes to this discussion by emphasising that although offenders are predominantly male, self-control and situational factors are relevant in explaining who commits image-based sexual abuse. Besides looking at offenders as parts of legitimising homo-social male groups, we should also consider that non-consensual sharers of sexual images are also young men, who are both at risk and risk takers.

\section{Further research and prevention campaigns}

The strong predictive effect of receiving images draws our attention to the role of the receipt of sexual images without consent. Previous research has measured the receipt of images and has explored the meaning of this receipt qualitatively (Mitchell et al., 2012). Receiving images might be considered a form of digital by-standing, but we still know very little about which experiences are connected to young people's receipt of images that they know have been shared without the consent of those who are depicted. Some of these bystanders are most likely consensual parties (for instance if they asked for the pictures), while others may be offended by receiving illegal materials if they have received them involuntarily. Conceptually, the bystander plays a crucial role, because the violation that occurs within image-based sexual abuse entails that an image must be non-consensually shared with a third party, but our findings suggest that this role is also very important in quantitative terms. In our data, we found that receiving images without consent was as common as sexting (with 


\section{8}

Sidsel Kirstine Harder et al.

consent), but we noted significant overlaps between these activities and offending. We suggest these overlaps as a new focus area for research.

In our data, four-fifths of the receivers did not offend, and thus we may think of the majority of receivers as intervening in image-based sexual abuse by not forwarding received images. Offending is hence not an automatic reaction among receivers, as self-control does have a substantial effect on offending within this group. This finding points to the importance of looking at both psychological personality traits and social/sexual situational factors within the last fifth of receivers who are also offenders: a group that includes three times more people than the offending group of those who share non-consensually without being receivers. We would encourage researchers to conduct qualitative explorations of these issues in order to form the basis for informed and knowledge-based prevention campaigns.

A successful campaign and dialogue against image-based sexual abuse should discern between sexting, receiving and offending in a manner well suited to include those who exhibit poor self-control, because these young people are more likely to give in to the temptation of offending through image-based sexual abuse. One way of exercising their self-control capabilities in this area could be to connect digital sexual risks to offline sexual risks (Albury et al., 2017). While the sharing of sexual images, either consensually or nonconsensually, is a new practice, the offenders share some of the same characteristics that young people at risk in other spheres of life do. Instead of inventing new models of prevention, it might make sense to draw on some of the same risk-management strategies that we know from other everyday practices in young people's lives. Having unsafe sex is more or less as common among young people as offending through image-based sexual abuse is, and in accordance with previous research on consensual sexting (Klettke et al., 2014), we have found significant overlaps between the young people who engage in the two sexual activities. We thus suggest that qualitative researchers should explore these connections more thoroughly in order to help design prevention campaigns that will combine the different areas.

\section{Limitations and strengths}

Along with practitioners and politicians, sociologists are currently working on definitions to conceptualise sexual image sharing with or without consent. In order to develop adequate and concise concepts, we see a dire need for more qualitative research on the overlaps between the different forms of activities and young people's accounts of image-based sexual abuse. Such abuse is a new phenomenon in which social research is trying to catch up with young people's everyday and criminal practices. This scenario means that our findings still have numerous limitations, which might lead to more questions than the findings have answered.

Among the limitations of our data is that the sample is biased, in that the survey was only distributed in 31 out of 98 Danish municipalities. The 
survey only included young people within the education system, and we cannot know who had entirely opted out of answering the voluntary survey. The results hence cannot be generalised to young people who are outside the educational system (at least after the mandatory education years); such youths are often marginalised within a society that expects young people to receive secondary education. The data is also drawn from self-reported responses, which carry biases related to reports of delinquent practices and personal issues, in that respondents are likely to be unwilling to admit to offending. That bias might be smaller in our survey, where all questionnaires were answered anonymously, and thus the survey might reveal more offending than crime statistics would. That being said, several factors apply to our study: (1) the survey is one of the only quantitative datasets available on image-based sexual abuse in Denmark, (2) the sample size is very large and (3) the questions are quite detailed, so the survey includes a range of different ways in which people can be involved in an activity: as offender, sexter, bystander and victim.

Within a quantitative framework, we believe that our most important limitation concerns the reliability and validity issues pertinent to the measurement scale we used for self-control. Tangney and colleagues (2004) developed the Brief Self-Control Scale as an instrument with 36 questions that measure various dimensions of task performance, impulse control, psychological adjustment, interpersonal relationships and moral dimensions. The authors found that a reduced version with 13 questions performed nearly as well, and the BSCS has since become 'one of the most widely used instruments for measuring general trait self-control' (Lindner, Nagy \& Retelsdorf, 2015, p. 465). Previous studies in the literature have measured self-control using everything from 24 items (Grasmick et al., 1993) to three items (Lee, Moak \& Walker, 2016); in light of the different possibilities, our use of 13 items thus falls within this range. The BSCS is not without its limitations, according to how the scale was developed, how it has been translated since then and how researchers use it. For example, we used a four-point Likert scale in the current study, whereas most other studies have used a five-point scale. This difference could affect how the variable is distributed; for example, we found that respondents typically ranked themselves as having more rather than less self-control. As for the reliability of our measure, it has internal consistency at the lowest acceptable level (Cronbach's alpha $=0.72$ ). Whether these imperfections have resulted in less precise estimates or have skewed them in one direction or the other we cannot say. Finally, the low pseudo $\mathrm{R}^{2}$ in our model (as shown in Table 13.3) suggests that many other factors beyond those that we have used in this study could be related to sexual digital violence, and we would especially encourage researchers to look into how other kinds of online/offline youth crime are associated with the non-consensual sharing of sexual imagery (Goldsmith \& Brewer, 2015).

To bridge the gap between the online and offline contexts, future quantitative explorations of image-based sexual abuse could also include the associations 
between offline peers and online crime. The opportunity structures could include the social dimensions of sexting, such as having friends who offend. Such an approach would be in line with Marganski's (2017, p. 188) findings; her work includes the normalisation of intimate behaviour that occurs through technology, and she argues that, especially in relation to youth, 'people may be more important in understanding behaviour than other measures of deterrence'. Marcum, Higgins and Ricketts tested this correlation vis-à-vis the sending of sexual images of oneself without the consent of the receiver and concluded that people who 'associate with deviant peers are more likely to engage in sexting' and that 'as self-control levels go down, the likelihood of sexting increases’ (2014, p. 75).

In our design, we were unable to include variables for friends who engage in the non-consensual sharing of sexual images, but we have included other social opportunity structure variables. By measuring engagement in unsafe sex, binge drinking and sexting, we go beyond the individual and account for specific sexual and social interactions with or without digital means.

\section{Conclusion}

This chapter has presented one of the first quantitative explorations of digital sexual violence in the Nordic countries. We have used the general theory of crime to explore the occurrence and correlates of image-based sexual abuse among a large sample of young Danes. We found self-control to be a significant predictor of this type of digital sexual violence, even though a substantial part of the effect was mediated by opportunity variables, such as unsafe sexual practices, sexting and binge drinking. Image-based sexual abuse offenders tend to be boys and young men whose poor self-control and risky choices in their sexual and social behaviours characterise them as both at risk and as risk seekers.

Receiving images without the consent of those who are pictured is the strongest predictor for sharing images non-consensually, which points to the future targeting of preventive measures to reduce image-based sexual abuse by addressing bystanders. The connection between different mainstream, deviant and criminal practices within sexual image sharing is a complex issue related to consent, social behaviours and individual characteristics. We suggest that researchers should further explore the relationships between risky social, sexual and digital behaviours in a qualitative manner in order to generate new knowledge about image-based sexual abuse offenders.

\section{Notes}

1 Danish elementary school grades 7-9, or upper secondary school.

2 A total of 434 observations fit these criteria among the sample of 61,289 , which was a sufficiently high number that statistical calculations were viable; while this number is a very small proportion of the whole sample, such low percentages are unavoidable in practice when looking at combinations of six variables. 


\section{References}

Albury, K., \& Crawford, K. (2012). Sexting, consent and young people's ethics: Beyond 'Megan's Story'. Continuum, 26(3), 463-473. https://doi.org/10.1080/10304312.2012. 665840

Albury, K., Hasinoff, A. A., \& Senft, T. (2017). From media abstinence to media production: Sexting, young people and education. In L. Allen \& M. L. Rasmussen (Eds.), The Palgrave handbook of sexuality education (pp. 527-545). London: Palgrave Macmillan. https://doi.org/10.1057/978-1-137-40033-8_26

Aneshensel, C. (2013). Theory-based data analysis for the social sciences. Thousand Oaks, CA: Sage. https://doi.org/10.4135/9781506335094

Barrense-Dias, Y., Berchtold, A., Surís, J.-C., \& Akre, C. (2017). Sexting and the definition issue. Journal of Adolescent Health, 61(5), 544-554. https://doi.org/10.1016/j. jadohealth.2017.05.009

Bates, S. (2017). Revenge porn and mental health. Feminist Criminology, 12(1), 22-42. https://doi.org/10.1177/1557085116654565

Cohen, L. E., \& Felson, M. (1979). Social change and crime rate trends: A routine activity approach. American Sociological Review, 44(4), 588-608. https://doi.org/10.2307/ 2094589

Cooper, K., Quayle, E., Jonsson, L., \& Svedin, C. G. (2016). Adolescents and self-taken sexual images: A review of the literature. Computers in Human Behavior, 55, 706-716. https://doi.org/10.1016/j.chb.2015.10.003

Dahl, K. M., Henze-Pedersen, S., Østergaard, S. V., \& Østergaard, J. (2018). Unges opfattelser af køn, krop og seksualitet (Young peoples perceptions of gender, body and sexuality). Copenhagen: VIVE - Viden til Velfærd. Det Nationale Forsknings- og Analysecenter for Velfærd.

Dake, J., Price, J., Maziarz, L., \& Ward, B. (2012). Prevalence and correlates of sexting behavior in adolescents. American Journal of Sexuality Education, 7(1), 1-15. https:// doi.org/10.1080/15546128.2012.650959

DeKeseredy, W. S., \& Schwartz, M. D. (2016). Thinking sociologically about image-based sexual abuse: The contribution of male peer support theory. Sexualization, Media, \& Society, 2(4), 1-8. https://doi.org/10.1177/2374623816684692

Demant, J., \& Østergaard, J. (2007). Partying as everyday life: Investigations of teenagers' leisure life. Journal of Youth Studies, 10(5), 517-537. https://doi.org/10.1080/ 13676260701594828

Döring, N. (2014). Consensual sexting among adolescents: Risk prevention through abstinence education or safer sexting? Cyberpsychology: Journal of Psychosocial Research on Cyberspace, 8(1). https://doi.org/10.5817/CP2014-1-9

Drouin, M., Vogel, K. N., Surbey, A., \& Stills, J. R. (2013). Let's talk about sexting, baby: Computer-mediated sexual behaviors among young adults. Computers in Human Behavior, 29(5), A25-A30. https://doi.org/10.1016/j.chb.2012.12.030

Gelman, A. (2008). Scaling regression inputs by dividing by two standard deviations. Statistics in Medicine, 27(15), 2865-2873. https://doi.org/10.1002/sim.3107

Goldsmith, A., \& Brewer, R. (2015). Digital drift and the criminal interaction order. Theoretical Criminology, 19(1), 112-130. https://doi.org/10.1177/1362480614538645

Gottfredson, M. R., \& Hirschi, T. (1990). A general theory of crime. Stanford, CA: Stanford University Press.

Grasmick, H. G., Tittle, C. R., Bursik, R. J., \& Arneklev, B. J. (1993). Testing the core empirical implications of Gottfredson and Hirschi's general theory of crime. 
Journal of Research in Crime and Delinquency, 30(1), 5-29. https://doi.org/10.1177/ 0022427893030001002

Handyside, S., \& Ringrose, J. (2017). Snapchat memory and youth digital sexual cultures: Mediated temporality, duration and affect. Journal of Gender Studies, 26(3), 347-360. https://doi.org/10.1080/09589236.2017.1280384

Henry, N., \& Powell, A. (2015). Beyond the 'sext': Technology-facilitated sexual violence and harassment against adult women. Australian \& New Zealand Journal of Criminology, 48(1), 104-118. https://doi.org/10.1177/0004865814524218

Henry, N., \& Powell, A. (2018). Technology-facilitated sexual violence: A literature review of empirical research. Trauma, Violence, \& Abuse, 19(2), 195-208. https://doi. org/10.1177/1524838016650189

Jørgensen, K. E. (2017). An explorative analysis of non-consensual online distribution of intimate visual material - between market dynamics and shame. Master's thesis, Department of Sociology, University of Copenhagen.

Kelly, L. (2013). Surviving Sexual Violence. Oxford, UK: Polity Press.

Klettke, B., Hallford, D. J., \& Mellor, D. J. (2014). Sexting prevalence and correlates: A systematic literature review. Clinical Psychology Review, 34(1), 44-53. https://doi. org/10.1016/j.cpr.2013.10.007

Korenis, P., \& Billick, S. B. (2014). Forensic implications: Adolescent sexting and cyberbullying. Psychiatric Quarterly, 85(1), 97-101. https://doi.org/10.1007/s11126013-9277-z

Langlois, G., \& Slane, A. (2017). Economies of reputation: The case of revenge porn. Communication and Critical/Cultural Studies, 14(2), 120-138. https://doi.org/10.1080/ 14791420.2016.1273534

Lee, C.-H., Moak, S., \& Walker, J. T. (2016). Effects of self-control, social control, and social learning on sexting behavior among South Korean youths. Youth \& Society, 48(2), 242-264. https://doi.org/10.1177/0044118X13490762

Lindner, C., Nagy, G., \& Retelsdorf, J. (2015). The dimensionality of the Brief SelfControl Scale - An evaluation of unidimensional and multidimensional applications. Personality and Individual Differences, 86, 465-473. https://doi.org/10.1016/j. paid.2015.07.006

Maddocks, S. (2018). From non-consensual pornography to image-based sexual abuse: Charting the course of a problem with many names. Australian Feminist Studies, 1-17. https://doi.org/10.1080/08164649.2018.1542592

Marcum, C. D., Higgins, G. E., \& Ricketts, M. L. (2014). Sexting behaviors among adolescents in rural North Carolina: A theoretical examination of low self-control and deviant peer association. International Journal of Cyber Criminology, 8(2), 68-78.

Marganski, A. (2017). Sexting in Poland and the United States: A comparative study of personal and social-situational factors. International Journal of Cyber Criminology, 11 (2). https://doi.org/10.5281/zenodo.1037385

McGlynn, C., Rackley, E., \& Houghton, R. (2017). Beyond 'revenge porn': The continuum of image-based sexual abuse. Feminist Legal Studies, 25(1), 25-46. https://doi.org/ 10.1007/s10691-017-9343-2

Mitchell, K. J., Finkelhor, D., Jones, L. M., \& Wolak, J. (2012). Prevalence and characteristics of youth sexting: A national study. Pediatrics, 129(1), 13-20. https://doi.org/ 10.1542/peds.2011-1730

Patrick, K., Heywood, W., Pitts, M. K., \& Mitchell, A. (2015). Demographic and behavioural correlates of six sexting behaviours among Australian secondary school students. Sexual Health, 12(6), 480-487. https://doi.org/10.1071/SH15004 
Powell, A., \& Henry, N. (2014). Blurred lines? Responding to 'sexting' and gender-based violence among young people. Children Australia, 39(2), 119-124. https://doi.org/ 10.1017/cha.2014.9

Powell, A., \& Henry, N. (2016). Technology-facilitated sexual violence victimization: Results from an online survey of Australian adults. Journal of Interpersonal Violence. https://doi.org/10.1177/0886260516672055

Powell, A., \& Henry, N. (2017). Sexual violence in a digital age. London: Palgrave Macmillan.

Renfrow, D. G., Kucewicz, K., Mouradian, K., \& Schweigert, V. (2017). 'But that's not sexting': Accounts from emerging adults. In O. Sefiha \& S. Brown (Eds.), Routledge handbook on deviance (pp. 322-363). New York: Routledge.

Reyns, B. W., Henson, B., \& Fisher, B. S. (2014). Digital deviance: Low self-control and opportunity as explanations of sexting among college students. Sociological Spectrum, 34(3), 273-292. https://doi.org/10.1080/02732173.2014.895642

Richards, R. D., \& Calvert, C. (2009). When sex and cell phones collide: Inside the prosecution of a teen sexting case. Hastings Communications and Entertainment Law Journal, 32, 1-40.

Ringrose, J., Harvey, L., Gill, R., \& Livingstone, S. (2013). Teen girls, sexual double standards and 'sexting': Gendered value in digital image exchange. Feminist Theory, 14(3), 305-323. https://doi.org/10.1177/1464700113499853

Svendsen, K. (2018). Working paper: Afmelder for Ungeprofilundersøgelsen. Copenhagen: Komiteen for Sundhedsoplysning.

Tangney, J. P., Baumeister, R. F., \& Boone, A. L. (2004). High self-control predicts good adjustment, less pathology, better grades, and interpersonal success. Journal of Personality, 72(2), 271-324. https://doi.org/10.1111/j.0022-3506.2004.00263.x

Walker, K., \& Sleath, E. (2017). A systematic review of the current knowledge regarding revenge pornography and non-consensual sharing of sexually explicit media. Aggression and Violent Behavior, 36, 9-24. https://doi.org/10.1016/j.avb.2017.06.010

Wolak, J., \& Finkelhor, D. (2011). Sexting: A typology. Research bulletin (March), Crimes against Children Research Center, University of New Hampshire, 13.

World Health Organization. (2012). Understanding and addressing violence against women. Sexual violence. Geneva: World Health Organization. 


\title{
14 Breaking the silence \\ Social media disclosures of sexual violence in Iceland
}

\author{
Rannveig Sigurvinsdóttir, Bryndís Björk \\ Ásgeirsdóttir and Sara Arnalds
}

\section{Introduction}

Sexual violence victimisation is common across the Nordic countries (Kloppen, Haugland, Svedin, Mæhle, \& Breivik, 2016). This type of victimisation relates to a range of maladaptive outcomes, including high levels of depressed mood, anger and anxiety (Asgeirsdottir, Gudjonsson, Sigurdsson, \& Sigfusdottir, 2010; Peleikis, Mykletum, \& Dahl, 2004; Sigurvinsdottir, Asgeirsdottir, Ullman, \& Sigfusdottir, 2017) and greater risk for suicidal and otherwise self-injurious behaviour, delinquency and substance use (Asgeirsdottir, Sigfusdottir, Gudjonsson, \& Sigurdsson, 2011; Sigfusdottir, Asgeirsdottir, Gudjonsson, \& Sigurdsson, 2008, 2013). Sexual violence is therefore an important public health problem with potentially lifealtering effects. Disclosures of sexual violence are a vital part of the recovery and well-being of survivors of sexual violence.

Evidence from the United States suggests that disclosures of violence have important implications for survivors, both in terms of the decision to disclose and the reactions people receive from others (Tener \& Murphy, 2015; Ullman, 1996a). Little is known about disclosures and social reactions in the Nordic countries, however. The introduction of social media has also given survivors a new way of sharing their experiences, such as traumatic events; these developments have yet to be explored adequately in the literature. In this chapter we examine Icelandic social media disclosures of sexual violence as well as explore the disclosure process, including determining why survivors disclose and studying the reactions they receive from others. Our findings from this study are exemplified from this post from a survivor: 'The day I talked about it, not just with those closest to me, but with the entire internet, was the day I finally became free'.

We have chosen to employ the term 'survivor' of sexual violence, rather than 'victim', because several authors have noted in the literature that this distinction is important to those involved, as well as to the surrounding community. A large body of literature has been devoted to this topic, from which we will provide a few examples in this chapter. In many cases, those who have experienced sexual violence reject the term 'victim' because they feel the word invokes stereotypes of someone who is weak and passive, which does not fit with their experience or sense of self (Donovan \& Hester, 2010). One example includes rape survivors in 
Bosnia-Herzegovina, who prefer to be called 'survivors' because, in their view, survivors can get family support, avoid personal guilt and seek justice against perpetrators. Victims, on the other hand, try to hide violence and feel guilt, shame and bodily pain (Skjelsbæk, 2006).

Other community members also distinguish between these terms: An experimental study of rape vignettes showed that participants perceived a raped woman more positively when she was termed a 'survivor' rather than a 'victim' (Papendick \& Bohner, 2017). The English-speaking participants in the study (which also included speakers of other languages) also found the term 'survivor' to be appropriate, especially when raped women applied this term to themselves. Given that we wish to emphasise the agency of survivors in disclosing their experiences on social media, and we do not wish to shame and blame them, we prefer the term 'survivor', even though we recognise that some may feel the word unnecessarily invokes ideas of life-threatening violence.

\section{Disclosure of sexual violence}

Disclosing sexual violence means to tell another person about an event or events, either formally or informally, and to do so either by self-motivation or following an invitation to tell (Ullman, 2003). Disclosures are crucial because without them, violence remains hidden, which makes it impossible to mobilise resources to help survivors and perpetrators. Survivors are more likely to disclose if they feel that doing so will benefit themselves or others and if they believe that societal norms would characterise the event as abusive (Tener \& Murphy, 2015). Survivors are most likely to disclose to those they trust, such as friends and family members (Tener \& Murphy, 2015). For example, one study found that young female rape survivors most commonly disclosed to friends first, followed by parents, other adults, partners and family members. Only $5.8 \%$ of the women told a professional about the event first, although slightly over half did at some point receive post-rape services (Bicanic, Hehenkamp, van de Putte, van Wijk, \& de Jong, 2015).

Numerous barriers to disclosure exist, including gender. For example, male survivors are less likely to disclose than female survivors (Bicanic et al., 2015; Hébert, Tourigny, Cyr, McDuff, \& Joly, 2009). Age is another barrier; children may wait months or even years to disclose after the first abusive event (Hébert et al., 2009; Jonzon \& Lindblad, 2004). In a Swedish study on female survivors of childhood sexual abuse, for instance, two-thirds of the respondents only disclosed in adulthood (Jonzon \& Lindblad, 2004). Adult disclosures can be self-motivated or prompted by others (Tener \& Murphy, 2015), such as by being asked or encouraged by a therapist (Alaggia, 2004) or other people in a relevant social network. Hence, the decision to disclose in adulthood is usually intentional, and survivors may go through times of self-dialogue about if, when and how it is best to disclose (Del Castillo \& Wright, 2009; Tener \& Murphy, 2015). Survivors' age therefore affects whether and how they decide to disclose.

Another barrier to disclosure is the survivor's fear of other people's negative reactions, as well as negative consequences following disclosure. For example, 


\section{6}

Rannveig Sigurvinsdóttir et al.

survivors may fear not being believed, hurting others or being rejected by family or friends (Tener \& Murphy, 2015). Survivors can also see disclosing violence as 'coming out', or admitting to having a concealable stigmatised identity information that is typically devalued by society but that is not obvious from one's appearance. To assume this type of identity can be a complex decision, because it may result in either receiving social support or being rejected by others (Pachankis, 2007). Ullman's (2000) social reactions framework, which we draw on in this chapter, examines how others react to disclosure and categorises those reactions into positive and negative reactions. Positive reactions include providing emotional support and tangible aid, while negative reactions involve blaming the survivor for the violence, taking control away, distracting the person (for example by drawing attention away from the violent event), treating the person differently than before the disclosure or acting in an egocentric manner. Research from the United States (Ullman, 1996a, 1999) has shown that relationships affect reactions, as friends, relatives and rape-crisis counsellors are the most likely to provide positive reactions, but negative reactions are more common among physicians and police officers. Reactions to disclosures (especially negative ones) relate to a range of maladaptive outcomes, such as depression, post-traumatic stress disorder (PTSD), the abuse of alcohol and substances and negative well-being (Orchowski, Untied, \& Gidycz, 2013; Sylaska \& Edwards, 2014; Ullman, 1996b). Survivors are therefore most likely to disclose to those they predict will be supportive, and they may be justified in fearing social reactions, because they can significantly affect their well-being.

Disclosing violence is a challenging process that involves gradual steps towards a comprehensive disclosure (Draucker \& Martsolf, 2008; Hébert et al., 2009). The first reaction may determine whether the survivor decides to continue disclosing. Some scholars also believe that the final stage of disclosing involves sharing the story with a wider audience, such as the media (Draucker \& Martsolf, 2008). Despite the prevalence of disclosures and the reported deleterious consequences of negative reactions for individuals and society, very limited Nordic research has been conducted on disclosures and their social reactions. The exception is a qualitative study from Norway in which both survivors and professionals were interviewed; the results confirmed the importance of the social context and the current lack of understanding of that context (Østby \& Stefansen, 2017).

\section{Social media disclosure of sexual violence and social reactions}

Disclosure researchers to date have focussed on in-person disclosures, where a survivor discloses to one person (or a small group), who then reacts in some way. This disclosure can happen once or multiple times. Recent digital advances, however, have opened new ways of disclosing violence by allowing survivors to do so on the Internet, for example using social media. Sharing one's story with a wider audience has become easier than ever before (Draucker \& Martsolf, 2008). The online context may therefore shape the process of disclosing. Disclosing online may have unique characteristics because of the medium itself, such as being able to 
instantly communicate with large groups, thus making the disclosure more public than traditional disclosures (Andalibi, Haimson, De Choudhury, \& Forte, 2016). Online disclosures may also allow for survivor anonymity, which is not possible with in-person disclosures. Online disclosures more readily allow for social reactions from strangers, which before the onset of social media were mostly made possible in very specific contexts, such as in court cases.

Telling others about one's experiences of sexual violence on social media may therefore be different from traditional in-person disclosures, but little is known about the characteristics of such disclosures of sexual violence. One study, however (Bogen, Bleiweiss, \& Orchowski, 2019), has examined social reactions on Twitter under the hashtag \#notokay in which women shared their experiences with violence. Bogen et al. (2019) examined comments made on sexual-violence disclosures and categorised them using Ullman's social reactions framework. The most common reaction was advocacy, where users challenged misinformation about sexual violence, as well as those who posted negative comments. Advocacy (which could also be termed 'activism') was not part of the original social reactions framework and may therefore be a key way in which disclosures differ online and in person.

Most of the available literature on social reactions was developed before social media emerged, so research is lacking on disclosing in that context. In this chapter, we explore and aim to further understand social media disclosures of sexual violence among Icelandic survivors. We will examine posts where survivors have self-disclosed sexual violence on social media. The goal is to understand these disclosures: when and how they happened, what they contain and how similar they are to traditional, in-person disclosures. We will also examine reactions to disclosures in a quantitative and qualitative manner to better understand what impact they may have had on survivors. We have used the social reactions framework to categorise reactions as either positive or negative. Other researchers will then be able to use this information to further study disclosures in other Nordic contexts, and in a more detailed way, in order to better understand how they shape the well-being of survivors and communities as a whole.

\section{Method}

\section{Data collection}

The data set for this project includes 397 self-disclosure posts collected from public social media sites posted between April 2015 and March 2017 (data collected in May and June 2017). All posts were written in Icelandic on either Twitter (166 posts) or Facebook (231 posts). The search strategy for Twitter posts was the use of keywords and hashtags associated with sexual violence in public accounts (ofbeldi, kynferðisofbeldi, \#daginneftir, \#konurtala, and \#pöggun ${ }^{I}$ ). Facebook data were drawn from a group called 'Beauty tips', which is a semi-public group for women (which had over 34,000 members as of June 2018) where all women who request to join are accepted. The group was originally formed for women to share 


\section{8}

Rannveig Sigurvinsdóttir et al.

information on fashion, hair, and makeup, but in May 2015, it spontaneously became a venue for women to disclose sexual victimisation, with the number of members in the group subsequently exploding. The same keywords that were used in the Twitter search were used when searching the group's page. Once posts had been identified that contained any of these keywords, they were reviewed to determine if they contained the inclusion criterion, which was a self-disclosure of sexual violence (and not a general discussion of violence or a disclosure of someone else's experiences).

\section{Data}

Basic descriptive information was gathered from the posts. Most survivors were female $(94.5 \%$, when gender could be determined). When the timing of violence was mentioned, most were found to have taken place in childhood (84.5\%); timing was mentioned in one-third of the posts. When perpetrator information was provided (as occurred in the majority of cases), most mentioned one perpetrator $(97.3 \%)$, who was male in $97.5 \%$ of cases and most commonly was a current/former romantic partner $(23.2 \%)$ or family member (15.6\%). Examples of sexual violence ranged from harassment, being forced to watch pornography and being touched on the outside of one's clothes to more serious acts, such as rape, attempted rape, exploitation of intoxication or sleep or forcing the survivor to have sex with others.

In addition to sexual violence, some posts also contained experiences of physical violence (such as slapping, beating, choking, ripping hair and more) and psychological violence (breaking survivors down with name calling, mocking, brainwashing and jealousy, among other actions). Repeated incidents of violence were observed in $14.4 \%$ of cases. About one-third of the participants had previously disclosed to someone in person; many of these had been delayed disclosures (close to half the disclosures involved events in the past three years). The longest time that had elapsed since victimisation was 35 years, and the shortest was a few days.

\section{Methodology}

When studying social media, it is important to realise the characteristics of the medium and how it can be approached. Our project has been informed by Rogers's (2013) notion of digital methodology; we believe that the Internet is not a realm inherently separate from the world. Rather, the online world acts as an extension of the 'real' world and exhibits continual interactions with traditional, in-person spaces. In this way, digital interactions can extend other types of communication and stimulate further interactions between members and networks of people (Rogers, 2013). We think this situation applies to online disclosures of sexual violence as well. Because the digital world can act as an extension of in-person spaces, disclosing on social media and in person can be thought of as intersecting circles, with certain commonalities and certain differences. For example, both involve telling one's own experiences and obtaining some form 
of reaction from others. Disclosing in person, however, can allow one to attain richer reactions, such as non-verbal cues, that are usually unavailable online. Social media disclosures, on the other hand, take place in a more public venue and could therefore be thought of not only as personal expression but also as a way of making a statement on the topic. The identities of those who use social media can also be formed in both the online and offline worlds simultaneously (Rogers, 2013) - a situation with potential implications for how survivors see themselves and other survivors who are part of the same movement.

Because the data were collected from social media sites, the data have unique characteristics that differ from those used in traditional social-science approaches. This scenario creates both advantages and challenges. For example, one particular benefit for research is that, rather than relying on self-reported experiences and disclosures, researchers can examine how and when disclosures happen. In addition, the data may more closely present the viewpoint of survivors, as the disclosures are self-motivated and presented in their own words, rather than being framed by researchers. Using survivors' words directly can be an empowering act that prioritises the lived experiences of survivors and their view of themselves. Having said that, online spaces also have informal social rules that will also shape the disclosure process and the language that is used.

Different online platforms may also shape what survivors want to share with others and what they feel is contextually appropriate. The level of detail in posts will differ on the platforms we have included in this chapter, as Twitter only allows posts to be a maximum of 140 characters, but Facebook does not have a length limit. We treat all the posts as one type of material in our analyses, however, because we found powerful disclosures and descriptions on both platforms. Other limitations also include focussing only on public sites, as well as the users of these sites being more likely to be young and female. The data set may therefore underrepresent the narratives of older women and of men, which reflects a generational norm in the use of technology and the disclosing of sexual violence, as well as a gendered norm in terms of self-disclosing sexual violence. When reading the analysis, it is important to keep in mind that the sample of disclosures is not representative of online disclosures in general. They offer an initial snapshot of what online disclosures include, as almost no information is available on this topic to date. Despite the characteristics and limitations of the data, we expect that these posts will tell us a great deal about online disclosures of sexual violence and how this topic could be studied in the future.

\section{Ethical considerations}

Social media research is developing quickly, so scholars have yet to agree on one single ethical standard or practice. The British Psychological Society (BSP), however, has published guidelines that we have followed in our work, called the 'Ethics Guidelines for Internet-Mediated Research'. The BPS explains that the four main principles for ethical conduct of research are: '1) Respect for autonomy, privacy and dignity of individuals and communities, 2) Scientific 
integrity, 3) Social responsibility and 4) Maximising benefits and minimising harm' (British Psychological Society, 2017, p. 2). These principles apply to the use of Internet data in multiple ways, such as (1) the question of whether public or private data is used and whether identifiable data is collected, (2) the informing of participants about data collection and (3) the gaining of consent for collecting data, when appropriate.

In addition to the BPS, the study was designed with guidance from the Icelandic Data Protection Authority (IDPA). We have taken measures to conduct this study ethically, for example by limiting our analyses to public data. On Twitter, this meant only finding posts from public accounts, but on Facebook, we sought content from the semi-public Facebook group Beauty tips, which the IDPA has ruled may be considered public content because of the group's large number of members. Before we collected data from the group, we posted information on the site to say that we were planning to conduct this study; we gave survivors a week to remove their posts or asked them to contact us if they did not wish to be included (which no one did). The posts were then collected without any identifying information. The purpose of the analysis is to examine broad themes about disclosure, so there should be no risk to individual participants. When we have wished to anonymously quote specific survivors, however - such as in this chapter and in previous presentations - we have sought explicit permission from survivors. Those we have contacted have all given their permission, and some have specifically remarked that they felt respected and empowered by their words being presented and discussed publicly.

\section{Analysis}

The analytical strategy for this project consists of coding and thematic analysis, which is an accessible and flexible method of identifying and organising themes in a data set (Braun \& Clarke, 2006). The process involves familiarising oneself with the data, generating initial codes and searching for, reviewing and naming themes. The final step involves generating a narrative summary of the results (Riger \& Sigurvinsdottir, 2015). First, we used deductive provisional coding, in which we gathered descriptive information from the posts based on previously defined categories (Saldaña, 2015). Examples of codes we used were whether an in-person disclosure was mentioned, what types of social reactions were given (both in-person and online) and what violence characteristics were mentioned, such as types of violence and severity. The authors created the coding scheme after reviewing the data set, and then the third author applied the scheme to each post. Second, we used inductive provisional coding to identify themes that emerged from the data set. For example, survivors who had experienced a sense of community very clearly emerged from the data. Once these codes were applied, we created broader themes by aggregating codes on similar topics that reflected similar meanings. The themes presented in this chapter were formed in both an inductive and deductive manner and are related to disclosure (i.e. they are facilitators to disclosure and reactions). 
The results section below broadly follows the process of disclosing violence. First, we focus on when the disclosures took place, then on what survivors described as facilitators and barriers, and finally on the reactions the disclosures elicited.

\section{Results}

\section{Societal discussions of sexual violence: an opportunity for disclosure}

One initial impression when examining the social media disclosures in the data set is that they occurred at very specific times, when a broader societal discussion of sexual violence was taking place. Figure 14.1 shows the number of posts over the time period of the study, from April 2015 to March 2017.

Figure 14.1 shows that the disclosures came in waves, with three clear spikes that coincided with public acts of activism. The first spike occurred in the summer of 2015, when the 'Beauty tips revolution' took place in May and June. These disclosures may have been motivated by seeing other survivors disclose, although the spike in disclosures also continued throughout July 2015. The Reykjavik 'Slut Walk', an event in which people protest sexual violence and shift the blame for violence from survivors to perpetrators, was held on 25 July 2015 for the fifth time. This type of survivor-positive event may therefore have facilitated some disclosures. The second spike in disclosures took place in November 2015, when large crowds gathered outside the main building of the Reykjavik Metropolitan Police to protest perceived leniency within a specific sexual assault case. The third spike took place in July 2016, when the Slut Walk was held for the sixth time. Between these time points, very few disclosure posts were published. These social media disclosures therefore seem connected to societal discussions of sexual violence and possibly by seeing other survivors leading by example.

\section{Number of posts}

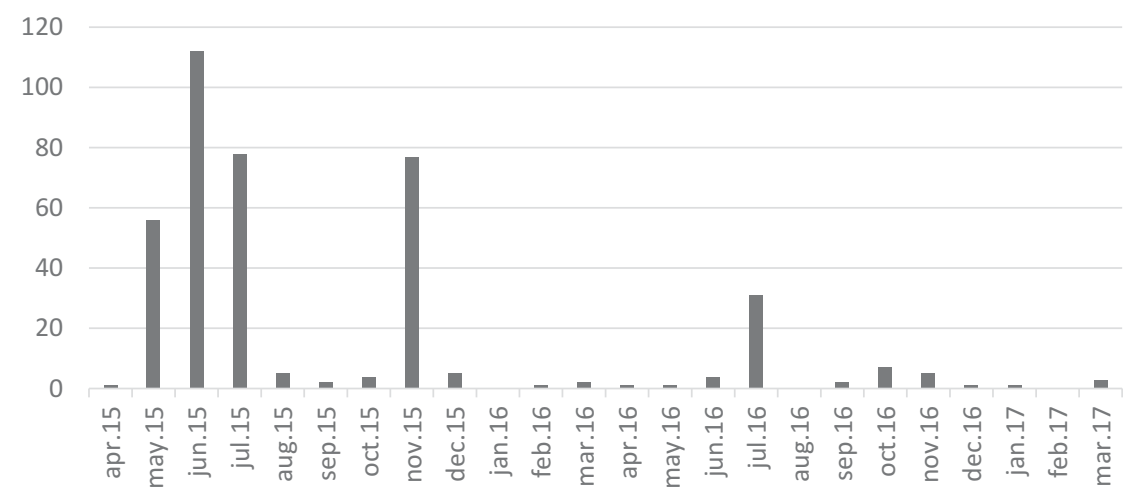

Figure 14.1 Number of self-disclosure posts of sexual violence over time. 


\section{Rannveig Sigurvinsdóttir et al.}

\section{Disclosures}

Survivors commonly explained in their posts why they had decided to disclose their experiences with sexual violence. The most common facilitator to disclosure was seeing others talk about their experiences, which was a major motivating factor to coming forward with their own stories. Here is one example (all translations in this chapter, from Icelandic to English, have been slightly edited for clarity and punctuation):

I'm so proud of you girls for telling your stories, because they've helped me get mine out and finally talking about it, and I encourage all women who've had to carry such a heavy burden to talk about it!

Another example illustrates that the survivor felt especially compelled to disclose after having seen a disclosure from a friend. It therefore seems important not just that survivors see someone else disclose but also that they feel some kind of personal connection (such as knowing the person or having had a similar kind of experience):

I've been looking at posts here from girls after this amazing revolution started and have been thinking how amazing it is for them!! I also thought that I'd never tell my story! Then I saw a post from one of my best friends, and it touched me, so I thought, why the hell am I keeping something secret and being ashamed for something that's not my fault?? So this is my story.

Survivors thus influenced others by telling their story in such a public manner, which they saw as a positive development. Another facilitator to disclosure was not only seeing others disclose but also feeling some kind of shared sense of community about the issue, which could reflect the fact that survivors saw how common violence is and that disclosures are typically met with understanding and support. Public discussions may therefore have contributed to an empowering sense of community between survivors:

I can barely describe how thankful I am for all of you. Countless stories have appeared on this site. These stories have helped me so much in the past few days. You are so strong, and now I'm going to be strong as well.

I'm sitting here with tears in my eyes after reading the stories here. Dearest girls, we need to stick together and bring attention to this very serious and important topic. You are heroes!

Some survivors even described that this sense of community had helped them disclose in person:

I've never been so proud to be an Icelandic woman as I am today. Because of you, I finally had the guts to tell my parents the whole truth. 
This sense of community was also reflected in the vocabulary people used in the posts, with the Icelandic equivalent of words such as 'bravery', 'pride' and 'hero' featuring prominently; in these descriptions, brave survivors were those who were willing to talk about their experience publicly. The group therefore saw some individuals as leading by example and being positive role models to others. This is a new dimension to disclosing that may be unique to disclosing online:

Thank you, girls, for beginning to talk and sharing. You are incredibly brave. I'm going to be brave like you.

This sense of community and solidarity in some cases even assumed an almost military-style language, which may have reflected the activism inherent in disclosing online:

I'm so proud of this revolution and will stand with this revolution and everyone who's told their story here until the bitter end.

These facilitators were very salient to the survivors, but the survivors also mentioned that they no longer experienced the barriers to disclosure that had previously held them back from telling their stories. Shame was the most significant barrier to disclosing and had significantly affected the lives of many survivors. This shame had kept survivors from talking about violence, but the fact that they no longer felt that way was one of the strongest themes found in the data set. They hence felt that talking about violence could counteract the negative effects of shame, especially when done in a way that would not blame survivors:

My whole life I've thought that it was my fault that it happened, because I got myself into the situation, but I know that that's not true.

I've never talked about it, because I always thought that the guilt and shame were mine, but today I know better!

Many survivors also stated that the survivor sense of community had helped them 'give the shame back' to the perpetrator:

Thank you for sharing your stories. It's great to feel this solidarity in breaking the silence and giving back the shame.

\section{Reactions to disclosures}

As shown previously, survivors reported experiencing a sense of community when they disclosed sexual violence. These stories are powerful, but the use of social media platforms also allows us to examine and even quantify the survivors' reactions to disclosures. At the time the posts were made, Facebook and Twitter only had the click option of 'liking' a post (today the options on Facebook represent a variety of 


\section{Rannveig Sigurvinsdóttir et al.}

feelings, such as anger, sadness, and more). The number of likes per post can be used as an indicator of how many people want to show the survivor some kind of support. The number of likes for the posts ranged from 0 to 2,300, with a median number of likes of 98. The number of comments ranged from 0 to 256, with a median number of reactions of 11 . This was a much higher number of reactions than could be expected when disclosing in person. The comments to the posts were overwhelmingly positive, if superficial. For example, many of the comments simply included a heart emoji or a few positive words about the survivor. In our material, we did not find a single negative reaction (although it is possible that someone could have made and then deleted a negative comment).

To provide some context for these reactions, we also examined the posts for reactions that survivors reported receiving in person from others. The positive in-person reactions were diverse, such as the rejection of the perpetrator by friends and family as well as romantic partners being patient with survivors who struggled with sexual activity following acts of violence. In fact, some survivors reported that reactions from others had helped the survivors define and frame the violent event itself and to seek help:

I immediately called my friend crying my eyes out and then hadn't fully realised that I'd been raped. I just felt terrible - felt dirty and completely broken down - but thankfully she realised straight away that I'd been raped, helped me see that, and told me to go straight to the emergency room.

Although the online reactions found in this data set were only positive, survivors generally receive a mixture of positive and negative reactions when they disclose in person (Sigurvinsdottir \& Ullman, 2015). In line with previous studies, the survivors examined in our material who had received negative reactions to in-person disclosure described how these reactions had affected them negatively:

When I talked about it [the violence] a few years later, others called me a liar because I hadn't fought back...I decided to just shut up and try to protect my reputation.

Negative reactions can also affect the seeking of help following violence:

I was going to press charges, but the first police officer I talked to said, 'But he is, after all, your boyfriend'. I walked out and never again tried to press charges - my soul was completely broken.

It is difficult to say whether getting online reactions may serve the same purpose as in-person reactions, with the latter seeming deeper and more meaningful to the survivor. At the same time, harmful negative reactions did not seem to have taken place in the online context of this study. Another possibility is that disclosing online had prompted some in-person reactions that could have been either positive or negative; whether these online disclosures had also prompted 
in-person reactions as well remains unclear. On the whole, online reactions' impacts on survivors require further examination.

\section{Discussion}

This study was an initial effort to examine social media disclosures of sexual violence, which are similar to in-person disclosures in that delayed disclosures are prominent (Bicanic et al., 2015; Hébert et al., 2009; Jonzon \& Lindblad, 2004). Seeing others disclose on social media is a powerful motivator for people to disclose. This scenario may be unique to the online context because of the public nature of the disclosure. These participants presented disclosing on social media as a crucial part of rejecting the shame they had felt and that others had projected onto them.

Social media disclosures can also serve to build social support and a sense of community among survivors, both of which affect survivor well-being (Tener \& Murphy, 2015; Ullman, 1999). Little is known about online communities of sexual violence survivors, although researchers have examined this issue for other topics. For example, receiving social support when self-disclosing mental health issues online is connected with fewer depressive symptoms and an increased quality of life (Rains \& Young, 2009). In addition, online support groups for breast cancer patients have been effective in reducing perceived stress, depression and cancerrelated trauma (Winzelberg et al., 2003). From the posts we examined, we cannot conclude that the survivors were positively affected by disclosing, but the salience of the social-support theme among the survivors is promising.

Societal discussions of violence may also facilitate online disclosures, which was visible from the timing of the disclosures. These time points, however, were characterised not only by discussions of sexual violence but also by very specific survivor-centred discussions that focussed on explicitly shifting blame from survivor to perpetrator. Discussing in this particular way, rather than having discussions of sexual violence in general, may therefore be the key ingredient to facilitate disclosure. The disclosure themes are also likely to converge. For example, societal discussions may be enough to motivate some survivors to come forward, while others will be motivated both by general discussions and by seeing others disclose. This situation is in line with previous research on in-person disclosures, where social norms regarding disclosure and violence are an important factor (Tener \& Murphy, 2015).

The social media themes can be placed in a theoretical context by using the disclosure process model, where individuals self-disclose some kind of a concealable stigmatised identity to others (Chaudoir \& Fisher, 2010). Being a sexualviolence survivor is such an identity, as the label is stigmatised and not obvious from one's appearance; in fact, many of the survivors in our study talked about online disclosures as a kind of 'coming out' process. The disclosure process model states that disclosing a concealable stigmatised identity may positively affect individuals and communities in the long term through three processes. First, not feeling able to share the experience with others can be taxing to the 


\section{Rannveig Sigurvinsdóttir et al.}

individual and can claim cognitive resources; indeed, our data show that survivors felt relief associated with sharing their experiences. Second, disclosure can have positive effects because it can lead to social support, which was very much the case with the survivors in our study; they reported feeling strong online social support from others. Finally, disclosure can have positive effects because people who have disclosed have now changed the social information now available about them to the world, which can then allow for people to change their behaviour accordingly, for example by seeking out communities of support among those with the same identity. The survivors in our study seemed to have entered this kind of community simply by disclosing in this way (Chaudoir \& Fisher, 2010). Even though the design of this study has not allowed for the health or well-being of the survivors to be assessed, the fact that the disclosure themes fit so well with previous research on positive outcomes is promising.

Reactions from others have an impact on survivors. This study has shown that online reactions were only positive, either as likes or positive comments, which is in accordance with the only other published study on online social reactions to date, where the majority of comments were positive, and the online community actively challenged negative comments (Bogen et al., 2019). Previous studies on in-person disclosures have shown that negative reactions are common, such as accusing the survivor of lying or blaming the survivor. Negative in-person reactions relate to overall well-being and poorer mental health, such as depressive symptoms, PTSD and the abuse of alcohol and substances (Orchowski et al., 2013; Sylaska \& Edwards, 2014; Ullman, 1996b). Positive in-person reactions are typically beneficial, but this effect is more modest than for negative reactions (Sigurvinsdottir \& Ullman, 2015). The in-person reactions presented in this study tended to fall into extreme positive and negative categories, which could reflect that extreme reactions (either good or bad) were the most salient to survivors and were therefore what they included in their posts. Reactions can significantly affect survivors in many ways, for example by defining the experience itself and from the closest community taking a stance (or not) about the survivor and perpetrator. This situation speaks to the importance of contextual factors in survivors' recovery.

When we compared online and in-person reactions, we found that online disclosures received a greater number of reactions than those in person (Dworkin, Pittenger, \& Allen, 2016; Littleton, Axsom, Breitkopf, \& Berenson, 2006). In addition, we found all the online social reactions to have been positive, although many of the comments seemed superficial. When survivors disclose in person, they typically receive both positive and negative reactions (Sigurvinsdottir \& Ullman, 2015). Researchers should thus focus on finding very detailed information about online reactions and how disclosures have shaped subsequent inperson reactions.

The dataset clearly displayed cultural narratives and norms about sexual violence. In some cases, survivors mentioned these narratives so that they could explicitly challenge them. For example, some survivors described that others 
had 'slut-shamed' them for their victimisation, and some had internalised their feelings of shame. The survivors mentioned these situations to point out how unfair and damaging this idea is, both in general and to individual survivors. In many cases, the survivors noted that the violence was not their fault, regardless of the circumstances. The survivors rejected the perceived cultural norm that survivors whose behaviour has not been impeccable were in some way 'asking for it'. We may think of this overt rejection of victim-blaming and other destructive cultural narratives as taking an activist stance against sexual violence. For example, Keller (2012) has argued that young people increasingly use various online spaces for political purposes. Not only does this create diverse communities and content, but it also opens up the possibility of non-traditional activism. In this way, survivors can organise themselves around the survivor identity, rather than using traditional divides of gender, race, class and other groupings. This element of activism also differentiates between traditional and social media disclosures, as in-person disclosures rarely contain such clear rejections of stereotypes and narratives about violence.

The posts also reinforced other potentially detrimental cultural narratives, however. For example, the language of the posts was very gendered, with repeated use of the word 'girls' and one survivor being 'proud to be an Icelandic woman'. Implicit in this language is the assumption that survivors of sexual violence are always female. Although statistics show that females are more likely to be victimised (Asgeirsdottir et al., 2011; Rajan et al., 2017), male survivors do exist, and they are somewhat excluded from this community of survivors. The digital aspect may also exclude older adults. The space that a community creates can therefore be very empowering for those within it, but such space does not seem to be available to everyone.

Because this research topic is so new, studies need to be conducted in the future to understand online disclosures and their impact; for example, the mental health implications of online disclosures and reactions remain poorly understood. In addition, no studies to date have examined how in-person and online disclosures and reactions shape each other, and whether people who disclose online will also disclose in person. In order to address these questions, a large longitudinal research project is planned in Iceland during the years 2018-2021 (Asgeirsdottir \& Sigurvinsdottir, 2018).

\section{Conclusion}

This study has been an initial effort to examine online disclosures of sexual violence. Given the profound impact that survivors have described in terms of the importance of disclosing, and the impact of the reactions survivors have received, we believe that the results highlight how important the social context is to survivors. Since the time the data were collected for this study, online disclosures have exploded worldwide with the \#metoo movement. We believe that gathering and analysing this type of information from Iceland may be useful to researchers in other Nordic countries who wish to study digital disclosure and supportive online 


\section{8}

Rannveig Sigurvinsdóttir et al.

communities. Even though the details of the disclosures will vary between countries and cultures, we think that researchers may use the broad themes developed in this study as a guide for future studies on this topic.

\section{Note}

1 Translations of search terms: violence, sexual violence, \#thenextday, \#womentalk, \#silencing.

\section{References}

Alaggia, R. (2004). Many ways of telling: Expanding conceptualizations of child sexual abuse disclosure. Child Abuse \& Neglect, 28, 1213-1227. doi:10.1016/j.chiabu.2004.03.01

Andalibi, N., Haimson, O. L., De Choudhury, M., \& Forte, A. (2016, May). Understanding social media disclosures of sexual abuse through the lenses of support seeking and anonymity. In Proceedings of the 2016 CHI Conference on Human Factors in Computing Systems, San Jose, CA, May 7-12 (pp. 3906-3918). New York: ACM.

Asgeirsdottir, B. B., Gudjonsson, G. G., Sigurdsson, J. F., \& Sigfusdottir, I. D. (2010). Protective mechanisms for depressed mood and anger among sexually abused adolescents: The importance of self-esteem. Personality and Individual Differences, 49, 402-407.

Asgeirsdottir, B. B., Sigfusdottir, I. D., Gudjonsson, G. G. \& Sigurdsson, J. F. (2011). Associations between sexual abuse, substance use and self-injurious behaviour: The mediating role of depressed mood and anger. Child Abuse \& Neglect, 35, 210-219.

Asgeirsdottir, B. B., \& Sigurvinsdottir, R. (2018, May). Breaking the silence on social media. Paper presented at the conference 'Focus on Sexual Violence', Reykjavik, Iceland.

Bicanic, I. A. E., Hehenkamp, L. M., van de Putte, E. M., van Wijk, A. J., \& de Jong, A. (2015). Predictors of delayed disclosure of rape in female adolescents and young adults. European Journal of Psychotraumatology, 6. doi:10.3402/ejpt.v6.25883

Bogen, K. W., Bleiweiss, K., \& Orchowski, L. M. (2019). Sexual violence is \#NotOkay: Social reactions to disclosures of sexual victimization on Twitter. Psychology of Violence, 9(1), 127-137.

Braun, V., \& Clarke, V. (2006). Using thematic analysis in psychology. Qualitative research in psychology, 3(2), 77-101.

British Psychological Society (2017). Ethics guidelines for internet-mediated research. INF206/04.2017. Leicester, UK: Author. Retrieved from www.bps.org.uk/news-andpolicy/ethics-guidelines-internet-mediated-research-2017

Chaudoir, S. R., \& Fisher, J. D. (2010). The disclosure processes model: Understanding disclosure decision making and postdisclosure outcomes among people living with a concealable stigmatized identity. Psychological Bulletin, 136(2), 236.

Del Castillo, D., \& Wright, M. O. (2009). The perils and possibilities in disclosing childhood sexual abuse to a romantic partner. Journal of Child Sexual Abuse, 18, 386-404. doi:10.1080/10538710903035230

Donovan, C., \& Hester, M. (2010). 'I hate the word "victim"': An exploration of recognition of domestic violence in same sex relationships. Social Policy and Society, 9(2), 279-289.

Draucker, C. B., \& Martsolf, D. S. (2008). Storying childhood sexual abuse. Qualitative Health Research, 18, 1034-1048. doi:10.1177/1049732308319925 
Dworkin, E. R., Pittenger, S. L., \& Allen, N. E. (2016). Disclosing sexual assault within social networks: A mixed-method investigation. American journal of community psychology, 57(1-2), 216-228.

Hébert, M., Tourigny, M., Cyr, M., McDuff, P., \& Joly, J. (2009). Prevalence of childhood sexual abuse and timing of disclosure in a representative sample of adults from Quebec. Canadian Journal of Psychiatry, 54(9), 631-635.

Jonzon, E., \& Lindblad, F. (2004). Disclosure, reactions, and social support: Findings from a sample of adult victims of child sexual abuse. Child Maltreatment, 9, 190-200. doi:10.1177/1077559504264263

Keller, J. M. (2012). Virtual feminisms: Girls' blogging communities, feminist activism, and participatory politics. Information, Communication \& Society, 15(3), 429-447.

Kloppen, K., Haugland, S., Svedin, C. G., Mæhle, M., \& Breivik, K. (2016). Prevalence of child sexual abuse in the Nordic countries: A literature review. Journal of Child Sexual Abuse, 25(1), 37-55.

Littleton, H. L., Axsom, D., Breitkopf, C. R., \& Berenson, A. (2006). Rape acknowledgment and postassault experiences: How acknowledgment status relates to disclosure, coping, worldview, and reactions received from others. Violence and Victims, 21(6), 761-778.

Orchowski, L. M., Untied, A. S., \& Gidycz, C. A. (2013). Social reactions to disclosure of sexual victimization and adjustment among survivors of sexual assault. Journal of Interpersonal Violence, 28(10), 2005-2023.

Østby, L., \& Stefansen, K. (2017). Nettverkets betydning etter seksuelle overgrep. (translation: The importance of social networks following sexual assault). Tidsskrift for psykisk helsearbeid, 14(3), 210-220.

Pachankis, J. E. (2007). The psychological implications of concealing a stigma: A cognitive-affective-behavioral model. Psychological Bulletin, 133, 328-345.

Papendick, M., \& Bohner, G. (2017). 'Passive victim-strong survivor'? Perceived meaning of labels applied to women who were raped. PloS ONE, 12(5), e0177550.

Peleikis, D. E., Mykletum, A., \& Dahl, A. A. (2004). The relative influence of childhood sexual abuse and other family background risk factors on adult adversities in female outpatients treated for anxiety disorders and depression. Child Abuse \& Neglect, 28, 61-76. doi:10.1016/j.chiabu.2003.08.003

Rains, S. A., \& Young, V. (2009). A meta-analysis of research on formal computer-mediated support groups: Examining group characteristics and health outcomes. Human Communication Research, 35(3), 309-336.

Rajan, G., Ljunggren, G., Wandell, P., Wahlstrom, L., Svedin, C. G., \& Carlsson, A. C. (2017). Diagnoses of sexual abuse and their common registered comorbidities in the total population of Stockholm. Journal of Epidemiology and Community Health, 71, 592-598. doi:10.1136/jech-2016-208105

Riger, S., \& Sigurvinsdottir, R. (2015). Thematic analysis. In L. A. Jason \& D. S. Glenwick (Eds.), Handbook of methodological approaches to community based research: Qualitative, quantitative and mixed methods (pp. 33-41). New York: Oxford University Press.

Rogers, R. (2013). Digital methods. Cambridge, MA: Massachusetts Institute of Technology.

Saldaña, J. (2015). The coding manual for qualitative researchers. Los Angeles, London, New Delhi, Singapore, and Washington, DC: Sage.

Sigfusdottir, I. D., Asgeirsdottir, B. B., Gudjonsson, G. G., \& Sigurdsson, J. F. (2013). Suicidal ideations and attempts among adolescents subjected to childhood sexual abuse and family conflict: The mediating role of anger and depressed mood. Journal of Adolescence, 36, 1227-1236. 
Sigfusdottir, I. D., Asgeirsdottir, B. B., Gudjonsson, G. H., \& Sigurdsson, J. F. (2008). A model of sexual abuses effects on suicidal behaviour and delinquency: The role of emotions as mediating factors. Journal of Youth and Adolescence, 37, 699-712.

Sigurvinsdottir, R., Asgeirsdottir, B. B., Ullman, S. E., \& Sigfusdottir, I. D. (2017). The impact of sexual abuse, family violence/conflict, spirituality, and religion on anger and depressed mood among adolescents. Journal of Interpersonal Violence, 1-21.

Sigurvinsdottir, R., \& Ullman, S. E. (2015). Social reactions, self-blame, and problem drinking in adult sexual assault survivors. Psychology of Violence, 5(2), 192.

Skjelsbæk, I. (2006). Victim and survivor: Narrated social identities of women who experienced rape during the war in Bosnia-Herzegovina. Feminism \& Psychology, 16(4), 373-403.

Sylaska, K. M., \& Edwards, K. M. (2014). Disclosure of intimate partner violence to informal social support network members: A review of the literature. Trauma, Violence, \& Abuse, 15(1), 3-21.

Tener, D. \& Murphy, S. B. (2015). Adult disclosure of child sexual abuse. Trauma, Violence, \& Abuse, 16, 391-400.

Ullman, S. E. (1996a). Do social reactions to sexual assault victims vary by support provider?. Violence and Victims, 11(2), 143-157.

Ullman, S. E. (1996b). Correlates and consequences of adult sexual assault disclosure. Journal of Interpersonal Violence, 11(4), 554-571.

Ullman, S. E. (1999). Social support and recovery from sexual assault: A review. Aggression and Violent Behavior, 4, 343-358.

Ullman, S. E. (2000). Psychometric characteristics of the Social Reactions Questionnaire: A measure of reactions to sexual assault victims. Psychology of Women Quarterly, 24(3), 257-271.

Ullman, S. E. (2003). Social reactions to child sexual abuse disclosures: A critical review. Journal of Child Sexual Abuse: Research, Treatment, \& Program Innovations for Victims, Survivors, \& Offenders, 12, 89-121. doi:10.1300/J070v12n01_05

Winzelberg, A. J., Classen, C., Alpers, G. W., Roberts, H., Koopman, C., Adams, R. E., ... Taylor, C. B. (2003). Evaluation of an internet support group for women with primary breast cancer. Cancer, 97(5), 1164-1173. 


\section{Index}

abuse: alcohol 38, 161, 173-174, 175, 207, 208-209, 211-212, 213, 220, 226, 236; and BDSM, group interviews 36 ; in LGBTQ relationship 36; psychological 33; sexual 21, 23, 29, 122-124; sexual, defined 122; see also specific entries acquaintances/friends, unwanted sexual touching by $54-58$

activism 227, 231, 233, 237

act-oriented criminal law 127-128

advocacy 227

affirmative consent $34,122,123$; see also consent

age, disclosure of sexual violence 225

aggressive touching 56-57

Alcoff, L. 24

Andersson, U. 19, 22-23, 27, 28, 29, $127-128$

anger 63, 109, 224, 234

anxiety $44,131,207,224$

armed conflicts and national contexts of rape 121

attitudes: feminist 41 ; to marital rape 92 ; to marriage, sexuality and gender inequality 85 ; to rape $28,85,127$

Bacchi, C. 137, 138-139

BDSM (bondage, discipline (or domination), sadism and masochism), sexuality and power exchanges in 33-46; BDSM and sexual violence, difference 34; BDSM as perversion, alternative sexuality or lifestyle, 37-41

blaming 168, 207, 225, 226, 231, 233, 235-237

boyfriends, unwanted sexual touching by 54-58

British Psychological Society (BPS) 229-230
Brownmiller, S. 22-23, 27, 28

bullying 160, 164

bystanders: image-based sexual abuse 217 ; of violence 158, 161, 167

Cahill, A. 23, 34, 51-53

campaigns 87

Canadian rape law 122-123

Carmody, M. 35, 39

children: disclosure of sexual violence 225; online sexual abuse 190-191; pornography 190, 191, 216; prostitution 190; sexual abuse 124,130

choking 228

CMC (computer-mediated communication) 190, 191-192, 198

coercive circumstances and rape law; see rape law and coercive circumstances

coercive sexual sadism disorder 40

Collins, R. 49, 52

Committee on the Elimination of Discrimination against Women 126 communication: CMC 190, 191-192, 198; F2F 190, 191; hyper-personal 192 'communicative model' of sexuality 123 community's responses to sexual violence: Bjästa case 156, 157, 158, 159, 160, 161, $163,164,165,166,167-168$; bonds 161 , 165; disclosures of sexual violence 224 , 225, 227, 230, 232-233, 235, 236, 237; online, sexual violence survivors 235 ; sense of 230, 232-233, 235

complainant's lawyer (CL), 137-138, 148-149; computer-mediated communication (CMC) 190, 191-192, 198 confinement 22

conflict zones, sexual violence in 26,121

consensual sadomasochism 40 


\section{2}

consent 34-39, 88, 91, 110; affirmative 34, 122, 123; in BDSM; see BDSM; coercive circumstances to, international law 125-126; erotics of 35; versus force 127-128; informed 193-194; misunderstanding signals/absence of 173, 174, 178, 179, 180, 182, 183, 184; mutual 40; prerequisite 115 ; regulation 114; requirement of 102; responsibility and 44-45; as state of mind 42-44; tacit 128 ; wives 83,90

consent-based legislation 102, 107, 109,116

contact rape 176

continuum, defined 21

Convention on the Elimination of All Forms of Discrimination against Women (CEDAW) 92, 93

Convention on the Rights of the Child (CRC) 190

convictions $26,106,107,111,115-116$, 128, 149, 192, 200

Cook, S. L. 67-68

coping mechanisms, negative 207

Cornell, D. 51-52

Council of Europe Convention 66, 126; see also Istanbul Convention

Criminal Act (Finland) 84, 91

criminalisation of marital rape: empirical analysis 86-88; justifications for 95-97

criminal law, formulation; see rape law; sexual autonomy; Swedish rape law

criminal liability 101, 114, 125

criminal responsibility 101, 127

Cullen, F. T. 68, 69

culture: alcohol intoxication 181; Danish sexual 172, 208; images of rape scenarios 183 ; media and education 26 ; narratives and norms about sexual violence 236-237; online rape 217; perceptions about rurality 167 ; sexual transgression 172, 181, 182, 183, 184; theorists 166

\#daginneftir 227

Dahl, S. 51, 56

Dahl, T. S. 21-22

Dahlberg, A. 110, 112

Danish Association for Women's Rights (Dansk Forening for Kvinderet) 140-141

Danish youth, image-based sexual abuse among; see digital sexual violence date rape 68 deindividuation 192, 197-198, 199

Denmark: image-based sexual abuse 210, 219; marital exemption 84, 89; sexual transgressions 174

depression 33, 44, 207, 224, 226, 235

digital sexual violence 205-220; defining image-based sexual abuse 206-207; discussion 216-220

disclosures, of sexual violence 224-238

discursive effects 139

discursive field 103

discursive framings of experience 25

discursive power 23,24

divorce 84, 91

domestic violence 19-20, 27, 29, 33, 66, 97, 126

dominance/submission relationships 38-39

drug 38, 181, 207

economic gender inequality 26

economic rights 89

emotional support 146, 157, 167-168, 226

emotions 52, 53, 60, 76, 166, 192

empowerment 36 .

ethically problematic sex 53

EU policy 139, 142

European Convention on Human Rights 126, 140

European Court of Human Rights (ECtHR) 121, 125-126, 140

European Court of Justice 111

European Parliament's Resolution on

Violence against Women 84

explorative touching 55-57

Facebook 161, 164, 167, 195, 227, 229, 230, 233

face-to-face (F2F) meetings 190, 191

family economy $72-74$

family support 225, 226

fear 52, 123-124, 128-129

feedback systems 26,28

female submission 38

feminist-informed legal analysis 151

feminist legal theorists 121

feminist theories 27, 29, 41

fetishism 37-40, 45-46

Fifty Shades series 37

Fileborn 60

Finnish rape law 122-125, 128

focus group 162

forced marriage 147

Foucault, M. 22, 23, 27, 35 
friends/acquaintances, unwanted sexual touching by $54-58$

Gavey, N. 24, 27

gender: cultures 29; disclosure of sexual violence 225; equality, lack of 155 ; hierarchies 29, 54

gender-based violence 27, 94, 97, 147 gendered power relations 22-23, 29, 41, 52 gendered welfare-state regimes 27 gender equality $40-41,83-84$ gender neutrality 85, 92, 93, 95, 97 gender-power dimension 21

Gilbert, N. 68

Goodwin, S. 139

'grey zone' acts 2, 23-30, 179, 182, 184, 181 guilt $23,114,143,159,163,166,180$, 225,233

Gunnarsson, L. 19, 23-25, 27, 28

helplessness/helpless state 123-124; see also Swedish Rape Law

Helseth, H. 52

heterosexual: marriage 89-90; stereotypes 54

heterosexuality 24

Hjemdal, O. 67, 77

human rights violation 21, 91, 120, 140

hyper-personal communication 192

identities $37-41$

illicit intercourse 84,88

illness $123-124$

image-based sexual abuse among Danish youth; see digital sexual violence

incapacitated sexual assault 50, 67, 72, 74,76

individual rights 89; see also Norwegian and Danish legal policies on complainants' rights

Instagram 195

International Classification of Diseases and Related Health Problems (ICD-11) 40

International Criminal Court 125

International Criminal Tribunals for Rwanda (ICTR) 120, 125

International Criminal Tribunals for the Former Yugoslavia (ICTY) 120, 125

Internet-mediated rape 189-202; computer-mediated communication 191-192; Internet-related sexual crimes 189-191

interpersonal violence, defined 20 intimate partner rape 128-130

intimate partner violence $20-21,29,33-35$, $83,87,94,97$

involuntary consent 129; see also consent

Istanbul Convention 66, 125; see also Council of Europe Convention

justice, public conception 106, 108

Kavanaugh, P. R. 55-57, 59

Kelly, L. 20, 24, 51

\#konurtala 227

Koss, M. P. 67-69

Krebs, C. 69

labour rights 89

lack-of-consent model 122-123, 127

legal discourse 103-110, 114

legality principle 127

legal representation for complainants 137 , $144,148-150$

legal texts on rape 22

Leijonhufvud, M. 109

Linnea 159-160, 163-164, 166, 167

lived effects 139

MacKinnon, C. 24, 25, 27, 125

male/masculinity 54 ; aggressiveness 54 ; dominance 38 ; entitlement 57,58 ; identity 25 ; power 20 ; sexuality 51, 183

Mardorossian, C. 22, 23

marginality 37

marital exemption 95

marital rape 68,128

marriage/marital contract/marital duties 85-86, 88-91, 96

McClintock, A. 38

media legitimacy 105-106

mental disease 40, 235, 237

Merry, S. E. 21

\#MeToo movement 1, 184, 237

micro-aggression 27

micro-sociological approach to study violence 49,52

mocking 228

morality 28; religiously based 88-92; sexual 91, 95; societal 87, 95-96

Munro, V. E. 121

mutual consent 40; see also consent

MVP (mentors in violence prevention) programme; see school-based MVP programme, classroom discussions on 


\section{Index}

Naffine, N. 87

negative reactions $226,234-235$

negligence 101, 103, 107, 108, 111

Newmahr, S. 37, 38

news media 172

Niemi-Kiesiläinen, J. 140

non-consensual image sharing 205-220

Nordic marriage reform 84, 96-97

Nordic welfare state model 85

Norris, J. 67-68

Norwegian Penal Code 77-78; §192, 189, $201 ; \S 291,202$

\#notokay 227

online bullying 164

online communities, supportive 235-236, 237-238

online disclosures; see social media disclosures

online sexual crimes 189,191

online support groups 235

opportunistic predation 55-56, 59

Oskar 159-160, 163-164, 166, 167

Oslo Pride festival 36

\#pöggun 227

parents' work-life participation $72-74$

Pateman, C. 35

paternalistic discourse 148-149

patriarchy 23,41

pejorative attitudes 127 ; see also attitudes penal-vaginal penetration, incapacitated 77 performative touching 54-55

personal integrity $85,87,114,147$

physical integrity 89

physical violence 127,228

political argumentation for women's rights 96-97

political mobilisation 22, 23, 29

pornography $183,189,190,191,207$, 216, 228

post-traumatic stress disorder (PTSD) 207, 226, 236

\#prataomdet ('talkaboutit') campaign in Sweden 24-25

psychological violence 228

public touching from strangers 58-59

Pylkkänen, A. 84, 87, 88

questionnaire 53-54; on sexual-victimisation experiences 71 ; on victimisation 70 random predation 59

rape: code 77-78; defined 189; defined by

Canadian law 123; defined by European

laws 126; defined by international law

125; defined by Norwegian law 66-67,

123; legal definitions of $40,41,86$; legal

texts on 22 ; myths 182,183 ; narratives

in the media 22 ; proclivity 183 ; as a war crime 125

rape and sexual violence, contemporary

theorisations of $18-30$;

conceptualisations of the victim 28 ;

continuum approach 20-22; different uses of 27-28; dialectic critical-realist approach 23-25; gender theory 28-29; institutional approach 25-27; structural intersectional approach 22-23; theoretical diversity and innovation 27

rape law and coercive circumstances 120-133; consent versus force 127-128; introduction 120-121; legal developments 122-126; rape and youth 130-132; rape in intimate relationships 128-130

rape-prevalence estimates, school-based survey experiment 66-80; rape measurement 67-69; pragmatic approach to $69-70$

religious-led sexual morals 88,92 religious views and marriage reforms 84 reproductive rights 89

revenge porn 207

Reykjavik 'Slut Walk’ 231

Riches, D. 20, 28, 44

Robberstad, A. 138, 139-142, 145

rumours $159-160,161,163-164,166,167$

rurality and sexual violence; see school-based MVP programme, classroom discussions on

sadomasochism (SM) 35, 37, 40

school-based MVP programme, classroom discussions on 155-168; sexual violence and rurality $156-157$

secondary victimisation 146-147

The Second Rape 159

self-control: BSCS 209-210, 211, 219; on image-based sexual abuse 216; influence of 205, 207-208; measuring 211;

opportunities and offending, relationship 209, 214-216, 218; poor 205, 207-208, 213, 217, 218

self-respect 122,130 
sex crime legislation 41

'sex-positive' queer theory 41

sexting 191; behaviours 208; campaign and

dialogue 218; consensual 208, 216, 217 ,

218; defined 190, 206; non-consensual

exchange of sexual images and 216; safe

205; self-control and 217; social

dimensions of 220

sexual arousal 166, 197-198

sexual autonomy 121-122, 127

sexual autonomy of wives, Finnish debate

83-97; criminalising rape in marriage in

1994, 92-95; Finnish legislation in the

late 1960s 88-92

sexual-ethics 51-53

Sexual Experiences Survey (SES) 67-68

sexual exploitation 105-106, 108, 112-113

sexual fetishism; see BDSM

sexual harassment on the street 51

sexual integrity $51,89,114$

sexual morality 91,95

sexual non-consent 124; see also consent

sexual offences, Swedish debate on 102

sexual offences reform 114; see also rape

law and coercive circumstances; Swedish

rape law, voluntariness in

sexual power 41

sexual sadism 40

sexual self-determination 114,121 ,

127-128

sexual touching, unwanted, social aspect of

49-63; situations involving friends/

acquaintances and boyfriends 54-58;

situations involving strangers $58-60$

sexual transgressions 171-185; accounts

for 173-178; and alcohol intoxication

178-181; as misunderstandings 181-184

sexual violence 96; and BDSM 39-41;

blind 59; defined 51, 206-207; gender

equality, lack of 155 ; legislative and

interventive efforts 156; levels 24; as

part of intimate partner violence 20-21;

prevention 34; in public accounts 227;

and rurality 156-157; see also

school-based MVP programme,

classroom discussions on; Sweden $155-156$

shame $23,63,180,225,233$, 236-237

\#silencing 238

Skype 195, 196

Slut Walk 231

Smart, C. 21 social activism 89,97

social control and sexuality 37

social-drinking arenas, unwanted touching in 51,59

social grey zone 179; see also grey zone acts

social media 22; disclosures of sexual violence 224-238; Internet-mediated rape 189, 195; sexual transgressions 172

social media disclosures 224-238;

disclosure of sexual violence 225-226; disclosure of social reactions 226-227; social stigma $40,45,131$

socio-economic characteristics and rape measures $72-75$

socio-legal ideologies 85,86

socio-spatial contexts of unwanted sexual touching 51-53; see also sexual touching, unwanted

Sørensen, B. W. 19-20, 27, 28-29

stigma management tools 172 ; see also social stigma

strangers, unwanted sexual touching by $58-60$

stress 38, 39, 69, 207-208, 226, 235-236

substance abuse 224, 226, 236; see also alcohol and drug

survivors, of sexual violence 224-227, 230, 231-233, 234, 235, 236-237

Swedish law 122-123

Swedish rape law, voluntariness in 101-117

tacit consent 128; see also consent

Techniques of neutralization 173

technology- facilitated violence 206-207

threat: of force towards lack of consent $122-125$; of violence 126

transgressions; see sexual transgressions trust 225; abuse 123, 130-132; see also rape law and coercive circumstances; issues, 207

Twitter 227, 229, 230, 233

unconsciousness 123-124

United Nations General Assembly 92

UN policy 139,142

unwanted touching on a continuum of sexual violence $21-22$

Vance, C. S. 62

victim and healthcare systems 26 


\section{Index}

victim(s) 21; blaming 168, 207, 225, 226, $231,235,236,237$; sexual violence 224 , 225; of violence, rural 157

vigilantism 149

violence 128; defined by World Health

Organization 34; gendered 93, 94;

physical 88-89; see also sexual violence

Violence within Marriage 93

vulnerability 172,194 ; children and youths 198; place-specific 157

Walby, S. 26-27, 28, 30

Weinberg, T. S. 37
Wetterberg, C. 84

Williams, R. 60

witnesses 20,158

women: being controlled 20; economic empowerment 26; human rights 91 ; movements 20-21; rights $89,93,94$, 96-97, 140-141; rights, political argumentation for 96-97

World Health Organization 34, 206-207

youth and rape 130-132; see also specific entries 